
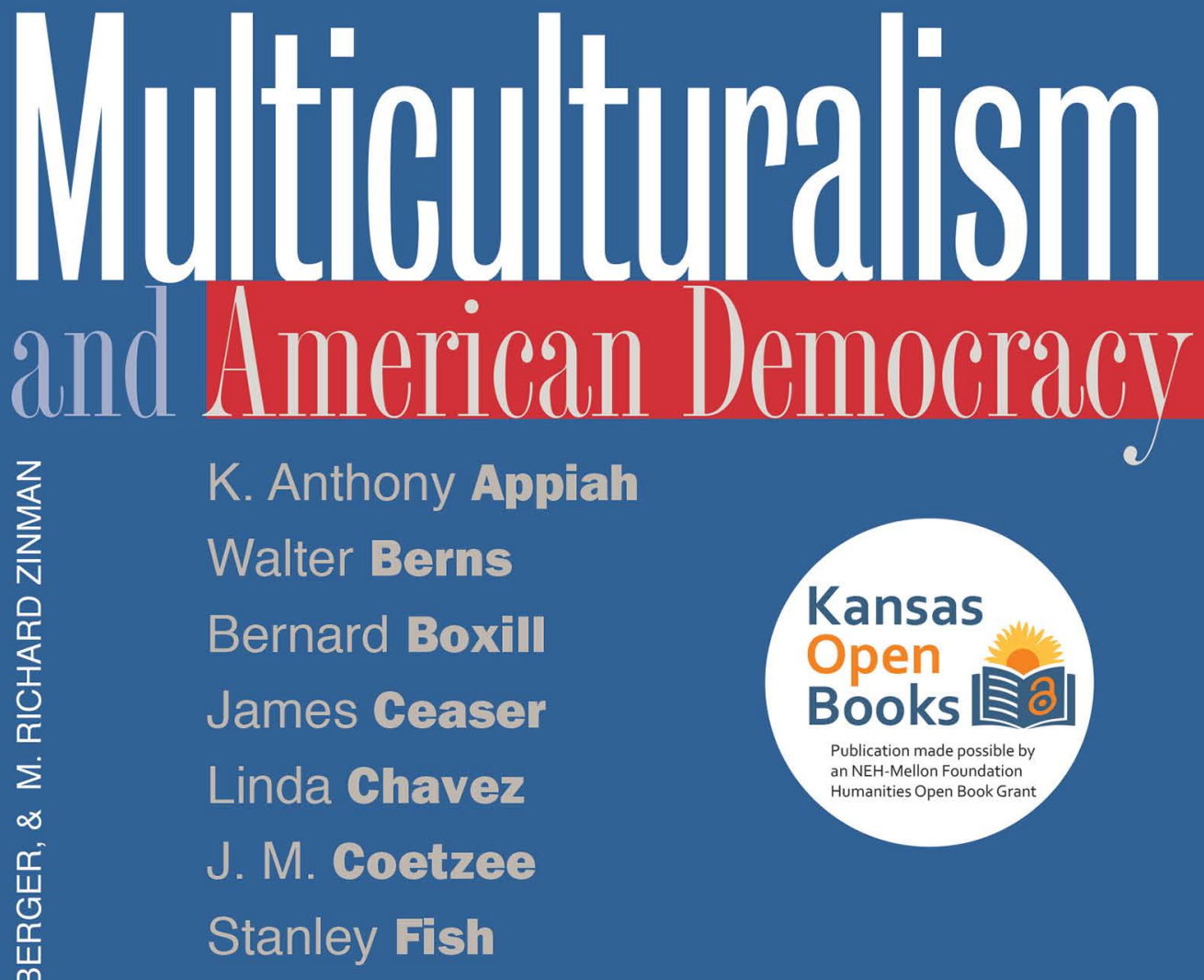

Kansas

Open Books $\approx$ 。

Publication made possible by an NEH-Mellon Foundation Humanities Open Book Grant

Nathan Glazer

Wilson Carey McWHIliams

Arthur M. Melzer

Anne Norton

Lorraine Pangle

Marc F. Plattner

Mario Vargas Llosa

Jerry Weinberger

C. Vann Woodward

M. Richard Zinman 
Multiculturalism and American Democracy 
Symposium on Science, Reason, and Modern Democracy MICHIGAN STATE UNIVERSITY 


\title{
Multiculturalism and American Democracy
}

\author{
Edited by \\ Arthur M. Melzer \\ Jerry Weinberger \\ M. Richard Zinman
}

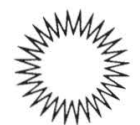

University Press of Kansas 
(C) 1998 by the University Press of Kansas

All rights reserved

Published by the University Press of Kansas (Lawrence, Kansas 66045), which was organized by the Kansas Board of Regents and is operated and funded by Emporia State University, Fort Hays State University, Kansas State University, Pittsburg State University, the University of Kansas, and Wichita State University

The text of this book is licensed under a Creative Commons AttributionNonCommercial-NoDerivatives 4.0 International Public License (https://creativecommons.org/licenses/by-nc-nd/4.0).

Open access edition funded by the National Endowment for Humanities and the Andrew W. Mellon Foundation Humanities Open Book Program.

Typographical errors may have been introduced in the digitization process.

Library of Congress Cataloging-in-Publication Data

Multiculturalism and American democracy / edited by Arthur M. Melzer, Jerry Weinberger, and M. Richard Zinman

p. $\mathrm{cm}$.

This volume grew from the fourth annual program of the Symposium on Science, Reason, and Modern Democracy: a lecture series that ran from September 1992 through March 1993 and a three-day conference held in April 1993. Includes bibliographical references and index.

ISBN 978-0-7006-0881-2 (cloth)

ISBN 978-0-7006-0882-9 (pbk.)

ISBN 978-0-7006-3112-4 (ebook)

1. Democracy-United States-Congresses. 2. Multiculturalism-United States-Congresses. 3. Pluralism (Social sciences) — United States - Congresses. I. Melzer, Arthur M. II. Weinberger, J. III. Zinman, M. Richard. IV. Symposium on Science, Reason, and Modern Democracy. JK1726.M77 $1998 \quad 305.8^{\prime} 00973$ - dc21 97-45707

The paper used in this publication meets the minimum requirements of the American National Standard for Permanence of Paper for Printed Library Materials Z39.48-1992. 


\section{CONTENTS}

Acknowledgments vii

Introduction 1

Arthur M. Melzer, Jerry Weinberger, and M. Richard Zinman

PART I. FROM PLURALISM TO MULTICULTURALISM

1. Is Assimilation Dead? 15

Nathan Glazer

2. The Limits of Pluralism 37

K. Anthony Appiah

3. Meanings for Multiculturalism 55

C. Vann Woodward

4. Boutique Multiculturalism 69

Stanley Fish

PART II. MULTICULTURALISM AND THE PRINCIPLES OF DEMOCRACY

5. Constitutionalism and Multiculturalism 91 Walter Berns

6. Majoritarian Democracy and Cultural Minorities 112 Bernard Boxill

7. Democratic Multiculturalism $\quad 120$

Wilson Carey McWilliams

8. The Virtues of Multiculturalism $\quad 130$

Anne Norton 
9. Multiculturalism and American Liberal Democracy James Ceaser

10. Liberal Democracy, Universalism, and Multiculturalism Marc F. Plattner

PART III. MULTICULTURALISM AND CIVIC EDUCATION

11. Civic Education in a Changing Society 165 Linda Chavez

12. Multiculturalism and Civic Education 173 Lorraine Pangle

PART IV. MULTICULTURALISM AND THE ARTS

13. What Is a Classic? 199

J. M. Coetzee

14. Fiction: The Power of Lies 216 Mario Vargas Llosa

List of Contributors 227

Index 231 


\section{ACKNOWLEDGMENTS}

This is the third volume of essays to be published by the Symposium on Science, Reason, and Modern Democracy. Established in 1989 in the Department of Political Science at Michigan State University, the symposium sponsors teaching, research, and public lectures on the relationship between liberal democracy and the great issues of contemporary life. This volume grew from the symposium's fourth annual program: a lecture series that ran from September 1992 through March 1993 and a three-day conference held in April 1993. All the essays presented here, with the exception of Mario Vargas Llosa's, were originally written for the program or especially for this volume. Stanley Fish's essay appeared later in Critical Inquiry 23 (Winter 1997), as did J. M. Coetzee's in Current Writing 5 (October 1993). Later versions of Nathan Glazer's essay were published in the Annals 530 (November 1993) and in his book We Are All Multiculturalists Now (Cambridge: Harvard University Press, 1997). An earlier version of Vargas Llosa's essay appeared in the New York Times Book Review (October 7, 1984). We thank Sage Publications and Harvard University Press for permission to reprint Professor Glazer's essay and the University of Chicago Press for permission to reprint Professor Fish's.

The symposium's 1992-93 program, and indeed all of its activities, was made possible by grants from the Lynde and Harry Bradley Foundation of Milwaukee, Wisconsin, the Carthage Foundation of Pittsburgh, Pennsylvania, and the Earhart Foundation of Ann Arbor, Michigan. We are grateful for their continuing support.

Michigan State's Department of Political Science has provided a congenial and lively home for the symposium. The Office of the Provost, the College of Social Science, and James Madison College have provided valuable encouragement and assistance. We thank our colleagues in each of these institutions. In particular, we thank Lou Anna K. Simon, provost and vice president for academic affairs; Kenneth E. Corey, dean of the College of 
Social Science; Brian Silver, former chair of the Department of Political Science; William Allen, dean of James Madison College; Kenneth Waltzer, former acting dean of James Madison College; Joshua Parens, the symposium's post-doctoral fellow for 1992-93; Patrick Jackson, our undergraduate assistant; and Patricia Thompson, Michigan State's art librarian, for their special contributions during our fourth year. We are grateful for the stellar support provided by Karen Battin, Rhonda Burns, Iris Dunn, and Elaine Eschtruth, the administrative staff of the Department of Political Science. Ms. Battin, the symposium's administrative coordinator, played a crucial role in the preparation of this volume. We thank her for her excellent work.

In addition to the authors whose essays are included in this volume, the following individuals took part in the symposium's 1992-93 program: Richard Delgado, Richard Flathman, Michael S. Greve, Michael W. McConnell, David K. Scott, Jean Stefancic, Rogers M. Smith, Ronald Takaki, and Kenneth Waltzer. We thank them for their important contributions.

Finally, we thank Fred M. Woodward, director of the University Press of Kansas, for his faith in this project. 


\section{Introduction}

Arthur M. Melzer, Jerry Weinberger, and M. Richard Zinman

After more than a decade of discussion, the subject of multiculturalism still remains bitterly controversial. This is a fact we have learned at first hand. Among the many people who have seen or heard these essays prior to publication, including four official readers, there was, in a sense, complete agreement: some of the essays are outstanding in their penetration, clarity, and fair-mindedness, while others are essentially useless and beside the point. There was almost total disagreement, however, as to which essays belonged in which category.

Partisan passion alone cannot account for this curious phenomenon. Equally important would seem to be the fact that multiculturalism, for all its influence and ubiquity, remains an unusually ill-defined movement. Some social movements, of which Marxism is the classic example, strive for precision and unanimity in their self-definition. The usual consequence, of course, is sectarianism. Multiculturalism, by contrast, is and seems content to remain quite amorphous. It has no recognized leader, no authoritative ideologist, no fundamental text, no official history. It is, of course, quite consistent, perhaps inevitable, that this particular movement should resist any single, monocultural formulation. But as a result, participants in this ideological debate, perhaps more than in any other, tend to experience their opponents as completely missing the point or as engaging in willful distortion.

With all of this in mind, we offer these essays to the public in the chastened hope that they will find some of them interesting.

Much as we might like to leave it at that, however, it is impossible, in a work of this kind, to escape the need for at least a working definition of multiculturalism. We will attempt to supply one, as well as to place this movement in some political and philosophical context. But we acknowledge from the start, because we know for a fact, that the remarks to follow are not acceptable to all the participants in this volume. 
If one considers the positive goals of multiculturalism, while ignoring for the moment all that it says and does in the struggle to achieve them, it can sound very much like traditional American liberalism. Both hold that discrimination and insensitivity are bad, toleration and cultural diversity are good, and we should all strive to treat each other with open-mindedness and respect. Amid all the boasts and fears about the subversion of Western civilization, it is not useless to spend a moment reflecting on the kinship of positive ends between the multicultural and liberal camps. Indeed, there are those, particularly on the left, who profess to see in multiculturalism only a repackaging of liberal pluralism. It is pluralism with added urgency and a new rhetoric, stemming from the theoretical insight that all cultures are necessarily constructed of multiple sources.

Doubtless, many people who now call themselves multiculturalists are indeed nothing but old liberals who have embraced this fresher and apparently more powerful rhetoric. But they do not form the core of the movement-or, at any rate, the core of what makes it new, important, and controversial. To do justice to multiculturalism, one must acknowledge the serious challenge it means to pose to traditional liberalism. To view it properly, one must place it in the context of the "radical tradition" of American politics, especially the various liberation movements of the sixties. Like these earlier movements, multiculturalism is radical because it holds that precisely the liberal goal of toleration and diversity cannot be achieved through liberal practices and modes of thought, but only through a fundamental transformation of institutions and consciousness.

Yet, despite this important kinship, the multicultural movement is also quite different from the liberation movements of thirty years ago. Indeed, the most distinctive features of the former come to light most clearly, we believe, through a contrast with the latter. What is the difference, let us then ask, between the multiculturalism of the nineties and the counterculture of the sixties?

Many of the differences are merely circumstantial, arising from the great changes that have occurred in this country over the last thirty years. Thus, the counterculture was fueled, in large part, by the kinds of discontents that arise within a nation at war, both hot and cold; whereas multiculturalism springs more from the kinds of long-repressed domestic discontents that burgeon in a nation suddenly at peace and without serious enemies. Perhaps for the same reason, as well as others, the counterculture was essentially a youth movement, whereas multiculturalism is not. 
But the most fundamental differences between the two movements, we believe, concern their ideological or theoretical differences. Generally speaking, the intellectual roots of sixties radicalism ultimately trace back, through Marcuse and the Frankfurt School, to Marx; whereas contemporary multiculturalism draws its most important concepts from postmodernist thought, which in turn ultimately stems from Marx's great antagonist, Nietzsche. This is not to claim, of course, that the two movements followed these two thinkers in any close, programmatic, or even conscious way. But each movement was decisively shaped by theoretical presuppositions and paradigms that received their first or most influential formulations in the two philosophers. The concrete meaning of this polar shift from Marx to Nietzsche can be seen in four fundamental changes that would seem to characterize or define multiculturalism, at least as we are given to see it.

First, as heirs of Marx, the sixties radicals were still the heirs of Enlightenment rationalism. To be sure, much of what made the New Left "new" was its concern for cultural and sexual liberation and a growing tendency to question rationalism - anticipations of contemporary multiculturalism. But in its leading political documents and strategies the New Left continued to embrace the idea of universal truth. In particular, it fought for the rights of women and minorities precisely by claiming that these rights were grounded in some objective and universal notion of truth and justice.

Multiculturalism, by contrast, tends to accept and build upon the Nietzschean rejection of rationalism. There is no universal truth or justice. Thus, multiculturalism fights for the rights of women and minorities in a new way: by subverting the truth-claims of all who would exclude them. Multiculturalists fight indirectly, not by claiming to have the truth themselves, but by denying that anyone else does. The premise is: where there is no truth, there can be no intolerance. The denial of truth will make us free.

Second, sixties radicalism, for all its emphasis on personal growth, remained primarily focused, in good Marxian fashion, on economic matters: on poverty, exploitation, and imperialism and on the economic deprivations of women and minorities. But in opposition to Marx, Nietzsche argued that the defining characteristic of human beings is the need not for material goods but for dignity and self-esteem. If we have our own "why" of life, he proclaimed, we can get along with almost any "how."

Multiculturalism largely accepts this Nietzschean premise. Therefore, the fundamental concern of the multicultural movement is no longer economics but esteem, not income but identity, and thus not Western capitalism 
but Western culture. For this reason, the main battleground has moved from "the system" to the school; and the main antagonists are understood not as economic classes, but as ethnic and racial groups. There has been a shift, in a word, from political economy to identity politics.

Third, the New Left, like Marx before it, focused ultimately on the welfare of the individual as opposed to that of larger groups or of the state: revolution would abolish social class and, with it, the state and nation as well. By contrast, multiculturalism, in the tradition of earlier nationalist thinkers including (in a complicated way) Nietzsche, tends to focus on the welfare of peoples or cultural groupings, which are seen as the source of the socially constructed identities of individuals. It emphasizes group over individual rights. Multiculturalism could in fact be called "left-wing nationalism": it seeks not indeed the unity and exaltation of the nation-state under the banner of the majority culture, but rather the loosening of the nation-state to protect the identity and self-confidence of the multiple subcultures.

Finally, Marx and the New Left saw the root of human oppression in the economic structure; and, although they regarded the liberal state's proclamation of freedom and equality as so much propaganda, they did look forward to the final elimination of oppression in a better economic order. Among multiculturalists, however, there is at least a strong tendency to view oppression as a relatively permanent feature of human life, stemming directly from a psychological drive for esteem and cultural hegemony or something like Nietzsche's "will to power." From this perspective, all claims to impartiality come to light as deceitful, all claims to objective truth as assertions of power. Consequently, multiculturalists tend to be more skeptical and grim than sixties radicals, to lack the latter's visionary idealism and sentimental oneworldism, and to advocate solutions that are consciously anti-utopian, involving separatism and other forms of permanently controlled conflict.

In sum, and with all due trepidation, we suggest the following working definition for multiculturalism: it is a movement that radicalizes and Nietzscheanizes the liberal ideal of tolerance-thus turning that ideal against liberalism - by tending to deny the possibility of universal truth as well as of nonoppressive power and by seeking, through this very denial, a comprehensive redistribution, not so much of wealth as of self-esteem, and not so much to individuals as to various marginalized groups.

Part I of this work presents disparate views of the stakes involved as older notions of pluralism and assimilation give way to multiculturalism. Nathan 
Glazer opens with a remarkable observation. While on the level of ideology the ideal of assimilation has been completely discredited in recent years, on the level of practice its power continues to grow, eroding once fixed boundaries of race, color, and religion. Assimilation and its logical result, intermarriage, proceed apace for Asians, Jews, Mestizo Latinos, and all other nonwhite newcomers. But one significant exception has persisted throughout the course of assimilation, "Americanization," and absorption of immigrant minorities: African Americans. For Glazer, this tragic black exceptionalism is the real source of multiculturalism, which blinds us to the great mixing taking place at the very time that we clamor for more separate and autonomous cultural identities.

Next, the call for such identities is examined by K. Anthony Appiah, but with a political perspective from beyond our shores. For Appiah, there is a crucial difference between multiculturalism in the strong sense that one finds in Africa-where racial and tribal differences threaten the integrity of the state as well as the pan-African identity that is still under constructionand the comparatively smoother and more easygoing pluralism that has been typical in the United States. The United States has always been multicultural in a weak sense, discouraging separate cultures-in the strong, anthropological sense of an exclusive way of life-while encouraging a plurality of cultures in the "high culture" sense of the interpretive and artistic expression of group experience. In Appiah's view, this is as it should be. But in an odd twist, America's universalistic exceptionalism still inclines us to ignorance of the ways of others, which in turn leads us to ignore the different high cultures that grow up in our largely European midst. Multiculturalism properly understood will encourage knowledge across high cultural boundaries and thus help cement the common bonds that unite us as a nation. Healthy multiculturalism is thus a corrective-but not an essential rival - to the older pluralism that was just never quite pluralistic enough.

C. Vann Woodward continues the discussion of these themes, but with a somewhat more skeptical outlook on recent calls for cultural diversity. In much the same vein as Glazer, Woodward argues that multiculturalism actually reflects white guilt at the one exception to an otherwise successful historical policy of assimilation. Given the vast number and diversity of America's immigrants, there was really no alternative to a policy of assimilation. African Americans were excluded from this policy and its good effects, but in spite of this tragic fact they too aimed for assimilation and integration-until recently. For Woodward, the cultural and political separatism 
now in the air are the results of legitimate and unanswered grievances, but that fact does not lessen the dangers posed by the more strident forms of multiculturalism that in his view have made alarming progress in the polity at large and especially in the universities. To the claims of Afrocentrists, Woodward responds that the idea of a common African culture is largely a myth hiding a dangerous multiculturalism, where tribalism and religious and ethnic divisions give rise to bloody conflict. Although it would be obtuse to ignore the grievances that fuel contemporary multiculturalism in America, Woodward warns against too much romanticism, especially in the universities, where it is even more likely than in the wider polity to do serious harm.

To these warnings, Stanley Fish essentially responds: "Relax, this is America." What Americans mean by "multiculturalism" is really a typical and largely harmless version of that old impossibility: having one's cake and eating it too. "Boutique multiculturalism" honors cultures in only their most superficial aspects, such as food and dress. Its very superficiality is rooted in a deeper loyalty to the principle of individual rational choice ("let's eat ethnic tonight") and is thus not real multiculturalism at all. "Strong multiculturalism" takes diversity much more seriously, but not so far as to accept the possible intolerance embedded in a given culture-for example, the death sentence declared against Salman Rushdie. Thus even strong multiculturalism is not real multiculturalism. But real multiculturalism—one that accepts the threat to Rushdie-is in fact monoculturalism and thus not multiculturalism at all. Those who fret about multiculturalism can stop worrying. Far from being a powerful idea opposed to liberalism, multiculturalism as a doctrine is in fact incoherent.

But liberals should not think this fact leaves their own principles as the only consistent game in town. For the inconsistency of multiculturalism has its counterpart in liberalism, especially when it comes to dealing with verbal assaults suffered by minorities. Fish argues that no consistent liberal policy is possible for preventing the harms of hate speech, so we must sometimes, perforce, use illiberal actions (the prohibition of some forms of speech) for the sake of liberal ends. For Fish, multiculturalism properly understood is not a doctrine, but an attitude governing the compassionate use of "inspired adhoccery" to address minority grievances.

In Part II of this work, the chapters turn to examine multiculturalism in its relation to the principles of democracy. Walter Berns leads off by arguing that multiculturalism is incompatible with the one thing that makes democracy possible: constitutionalism. In effect, Berns argues that the American 
founders addressed something like the multiculturalism of Fish's monocultural variety: they took multiculturalism as the mutually exclusive teachings of different religions. To avoid the danger of religious conflict, the Constitution banished multiculturalism to the sphere of private life, stripping it of all public power or recognition. But for Berns, this does not mean that the Constitution is merely neutral as regards all ways of life and especially as regards religion. It is clearly incompatible with some religions and hence some cultures (i.e., any culture that would claim the right to kill Salman Rushdie). For Berns, this fact shows how dangerous it is for multiculturalists to denounce the Constitution as the tool of white male hegemony. When we realize how divisive religion can be outside of our constitutional order, the moderate hegemony of constitutional norms makes perfect democratic and even multicultural sense.

Bernard Boxill then makes the case for multiculturalism as a means for preserving the fundamental goal of constitutional democracy: preventing majority tyranny. In our present situation of increasing diversity, constitutional rules as we know them seem able to preserve minorities' most basic interests. But these rules are not sufficient to allow for the flourishing of minorities and thus do not encourage the contributions, both cultural and political, that minorities might otherwise provide to the polity as a whole. Universal enfranchisement does not ensure actual representation for minorities, at least not without confining them to isolated electoral districts. Following J. S. Mill, Boxill argues that the actual representation of minorities is good both for minorities and for the democratic polity as a whole, which stands to learn from perspectives and ideas that are not otherwise available. Since the Constitution is notoriously silent about the rules for voting, Boxill, again following Mill, suggests that we take seriously Thomas Hare's system based on the single transferable vote. For Boxill, both the Constitution and constitutionalism will be enhanced by reforms that put brakes on majoritarian democracy and empower minorities, whose political voices tend to get lost in the larger majority crowd.

Wilson Carey McWilliams thinks liberal democracy can come to terms with multiculturalism, as it did earlier in the case of religion, but he is more concerned than is Boxill about the moral conditions for any possible accommodation. According to McWilliams, democracy is a "hard school," in which the forms and laws protecting inalienable individual rights often require that our individual and group interests be calculated and even bargained away. As a result, all cultures and faiths in America become involved 
in a process of "learning, forgetting, and selective memory that lays down boundaries of community and the civil meaning of the term 'American." " McWilliams warns contemporary multiculturalists not to forget this hard fact. In a democracy, a subculture must adhere to the central tenets of democracy, which more often than not involve the dilution or compromise of that subculture's central beliefs. In particular, the current multicultural doctrine of the equality of all cultures is especially problematic. Such a view not only disdains the actual practice of cultures, which themselves regularly judge the relative merits of other cultures; it also denies the principle of equality as such. For as both Berns and Fish imply, if all cultures are equal, then we must accept the castes, racism, domination, sexism, and other forms of inequality embraced by some cultures.

Anne Norton then defends multiculturalism by appealing to the principles of its critics. In her eyes, multiculturalism fosters responsibility, inventiveness, and a generally critical spirit—all virtues necessary for a robust democracy. Moreover, multiculturalism contributes to the constitutional end of preventing majority tyranny, while at the same time combating the tendency toward mediocrity that always threatens the culture of an egalitarian democracy like our own. Thus Norton argues that multiculturalism actually fosters virtues more associated with aristocracy than with democracyvirtues such as magnanimity, friendship, and the love of learning. Invoking the spirit of Tocqueville, Norton argues that multiculturalism combats the leveling that stalks democratic culture and endangers democratic liberty.

James Ceaser breaks this sanguine mood with a hard-hitting argument that multiculturalism is conceptually and morally incoherent and at once parasitically dependent on and yet politically dangerous for liberal democracy. Multiculturalism claims to take seriously the diversity and multiplicity of cultures. But in fact there is nothing "multi" about it. Rather, multiculturalism divides the whole of human kind into two categories: "Hegemon" and "Other." The Hegemon is the white male European wrapped protectively in the liberal political order; the Other is composed of all the cultures he suppresses. But the dichotomy really makes no sense. First, its philosophical provenance consists solely of the thought of dead white European males. Second, the multicultural political agenda depends on liberal white guilt (pretty wimpy hegemons, those WASPS). And finally, it completely distorts the phenomenon of culture in America. Thus there are no separate cultures within the Hegemon-as if the Irish, the Italians, and Michigan's Finns are all the same, experienced no neglect, and hence can claim no compensation on mul- 
ticultural grounds. These groups do have one thing in common: they are all white; and, for Ceaser, herein lies the ugly secret of multiculturalism. For all of its talk about the social construction of group identity, in practice multiculturalism recognizes only nature-biology, race, and color.

In its ham-handed distortion of cultural reality — not just of the Hegemon, but also of the Other, which it describes with such racialist and culturally inaccurate categories as "Asian" and "Latino"-multiculturalism obscures the lessons that can be learned from the actual history of cultural and group politics in our liberal order. The liberal ideal of culture-free individualism was always something of a fiction, says Ceaser. Especially in big city politics and the national parties, group identities and interests indeed played major roles in the past. But these identities and interests were always informal and were never embodied in law or administrative rules. As a result, group identity ebbed and flowed: to be Irish or Italian in America no longer means today what it did sixty years ago. The color-blind individualism of the civil rights movement helped to erode many of the informal institutions once used by ethnic groups. At a later time, the ironic result has been the replacement of these informal institutions by a legal regime of preferences based solely on race. This fact, buttressed by the legitimizing theory of multiculturalism, cannot bode well for liberal democracy. For we can no longer be sure that group identity will be fluid, as it must be in a liberal order. It is now more likely that the really nasty aspects of culture will take advantage of the current multicultural regime. And no wonder, for the upshot of multiculturalism is racialism and biologism - the really great vices of Europe-which our founders sought to escape and which have done such harm to us to the extent that we did not.

In an equally hard-hitting essay, Marc Plattner ends the second part by arguing that when viewed from the international perspective, the whole multiculturalism debate appears strikingly "Amerocentric." The American multiculturalist, eager to press some political and cultural claim, insists that all universal principles are mere rationales for the domination of one group over others. But for the struggling dissidents who risk life and limb for freedom in faraway lands, the universal principles of human rights are life's very blood. And so while the rest of the world increasingly appeals to universal principles of rights and democracy, we treat that universalism with increasing contempt and disregard.

From politics, Part III turns to the question of multiculturalism and civic education. According to Linda Chavez, it is a mistake to think that the multicultural aspects of civic education should focus on the preservation 
of the many distinctive cultures associated with racial and ethnic groups. Groups have every right to pursue such interests; indeed, it is healthy that they should do so. But education along these lines must be carried out in private-in families and in communal organizations. To be sure, our civic education, if it lacked a multicultural dimension, would distort the reality of American experience and history, which is in large part the story of ethnic pluralism. But healthy multiculturalism should aim to show the common elements in American culture-those mores and institutions, shared by all, that make it possible for different groups to express their cultural lives in private and as they, not the government, see fit.

Lorraine Pangle next argues that the new multicultural thrust in civic education actually reproduces the vices of the old monocultural education it criticizes. It merely replaces one narrow, parochial, and shallow view of our history and civic culture with a variety of equally narrow, parochial, and shallow views, with each group exhorted-as a matter of therapeutic necessity-to take pride in what is simply its own. But therapy and group pride are no substitutes for genuine education of mind and character. What we need, says Pangle, is a really serious multiculturalism, one that encourages the student to look both above and beyond the limitations of any given culture. We must get beyond the stultifying categories of "absolutism" and "relativism"- both of which serve to encourage the lazy satisfaction with what is most familiar. For Pangle, genuine multiculturalism will transform civic education into liberal education. And well it should, for no civic education worth its salt should take civic concerns as the sole horizon for the mind or spirit. A proper multiculturalism, then, takes humanity as its ultimate theme.

A radical multiculturalist might respond, however, that Pangle's conclusion begs the fundamental question: Is there such a thing as universal humanity-discoverable by the humanities - that transcends particular political memberships and group identities? Or is such humanity an ideological fiction that hides the political hegemony of Western culture? Is there a real difference between the supposedly universal experience reflected in a Bach fugue and the particular function of the Papuan war dance? Is the culture that produced Bach properly called high and the Papuans' low? Are Shakespeare and the King James Bible genuine windows to the essence of human life, or might comic books be just as revelatory of the human condition that, in truth, has no real essence and is determined by cultural construction?

A moderate multiculturalist would reject these extreme alternatives, but might nevertheless find our genuine humanity too complex and elusive- 
and too filtered through cultural experience- to be captured by any rigid list of classics or "great books." The issue is not high and low culture, but good and bad works of art, and the latter come in many forms and from many and diverse cultural experiences. We must be careful not to deify certain authors and works, however great they may be, lest we restrict our horizons and miss pictures of the human condition that are as rich and revealing as the ones we associate with the traditional curriculum.

These questions - so familiar from the "canon" wars - go to the heart of multiculturalism, and precisely because the latter as a political movement blurs the old distinction between material and cultural goods. The political stakes are identities, and identity involves culture. Small wonder, then, that multicultural debates about the arts, and especially about the university curriculum and great books, are so heated and so easily distorted by passion, ideological commitment, and interests that seem extrinsic to the arts themselves.

To get a fresh perspective on these questions, we wanted them discussed by accomplished writers from multicultural societies other than America. J. M. Coetzee and Mario Vargas Llosa were especially appropriate because both had at first declined our invitation, on the grounds that the discussion of multiculturalism and the arts was, in America, mired in our unique national preoccupations: race and the underclass, feminism, immigration and assimilation. They appear here, in Part IV, because we encouraged them to speak from above our local frays.

In "What Is a Classic?" J. M. Coetzee considers what classical perfection means at a time when historicism is the reigning frame of mind. After a subtle discussion of T. S. Eliot and J. S. Bach, Coetzee concludes that "the classic defines itself by surviving" in the course of regular testing by those professionals who teach and learn the various creative arts. The classic work emerges from the simple fact that such professionals - who would not struggle with a work whose "life functions have been terminated" - continue to repair to it. If shielded from critical attack, the classic "can never prove itself" in this professional way and thus become the broader social phenomenon we commonly mean by the term "classic." Thus, criticism, even of the most skeptical and multicultural kind, is not the foe of the classic, but its unwitting savior.

Finally, in "Fiction: The Power of Lies," Mario Vargas Llosa tells us that all good fiction lies, but not in the way commonly suggested by more radical multiculturalism, that is, by covering up and legitimizing existing power relations or by creating the "constructions" that establish cultural identity. 
Rather, fiction responds to the simple fact that all human beings, regardless of their station or culture, long for lives they do not have. The lies of fiction reflect this unchanging truth of the human condition. Great fiction creates a world in which the reader can live with an impunity not granted by real life. For Vargas Llosa, the open deceptiveness of literature marks it off from mere propaganda; and a sure sign of totalitarianism is a blurring of the distinctions among fiction, politics, and history. Great fiction is an indictment of life under any regime or ideology. It thus demonstrates the permanent inadequacy of any merely civic culture-however narrow, pluralistic, or multicultural it may be. 


\section{Part I}

From Pluralism to Multiculturalism 
This page intentionally left blank 


\title{
Chapter 1 \\ Is Assimilation Dead?
}

\author{
Nathan Glazer
}

\begin{abstract}
"Assimilation" is not today a popular term. Recently I asked a group of Harvard students taking a class on race and ethnicity in the United States what their attitude to the term "assimilation" was. The large majority had a negative reaction to it. Had I asked what they thought of the term "Americanization," the reaction I am sure would have been even more hostile. The "melting pot" is no longer a uniformly praised metaphor for American society, as it once was. It suggests too much a forced conformity, and reminds people today not of the welcome in American society of so many groups and races, but rather of American society's demands on those it allows to enter. Indeed, in recent years it has been taken for granted that assimilation, either as an expectation of how different ethnic and racial groups would respond to their common presence in one society, or as an ideal as to how the society should evolve, or as the expected result of a sober social scientific analysis of the ultimate consequence of the meeting of people and races, is to be rejected. Our ethnic and racial reality, we are told, does not exhibit the effects of assimilation; our social science should not expect it; and as an ideal it is somewhat disreputable, opposed to the reality of both individual and group difference and to the claims that such differences should be recognized and celebrated.
\end{abstract}

One might think there is nothing left to say. The idea that it would happen, that it should happen, has simply been discredited, and we live with a new reality. It was once called cultural pluralism, it is now called multiculturalism, and whatever the complications created by the term for educational policy, or for public policy in various other realms, that is what we must live with, and all of us seem to be ranged along a spectrum of greater or lesser enthusiasm for and acceptance of the new reality. Even critics of the new multiculturalism take their places within this spectrum. Those who truly stand against it, the true advocates and prophets of a full assimilationism, are so minuscule in American public and intellectual life that they can 
scarcely be discerned in public discussion. One can point to the journal Chronicles, and scarcely anything else. Neither liberals nor neoliberals, conservatives nor neoconservatives, have much good to say about assimilation, and only a branch of paleoconservatism can now be mustered in its defense. It is only adherents of this hardly potent branch of conservatism who would argue that even if assimilation has not yet happened, it is something that, despite the reverses of the past thirty years, should have happened, and should still happen.

Yet assimilation, properly understood, is neither a dead hope nor a demeaning concept: It is rather, I will argue, still the most powerful force affecting the ethnic and racial elements of the United States. Our problem in recognizing this has to do with one great failure of assimilation in American life, the incorporation of the African American, a failure that has led in its turn to a more general counterattack on the ideology of assimilation.

But to go back: What was assimilation? It was the expectation that a new man would be born, was being born, in the United States. We can go back to that much quoted comment on what was the American, in Crèvecoeur's Letters from an American Farmer of 1782: "What then is the American, this new man? He is either a European or the descendant of a European, hence that strange mixture of blood, which you will find in no other country. I could point out to you a family whose grandfather was an Englishman, whose wife was Dutch, whose son married a French woman, and whose present four sons have four wives of four different nations. He is an American, who, leaving behind him all his ancient prejudices and manners, receives new ones from the new mode of life he has embraced, the new government he obeys, and the new rank he holds."

This passage, which Philip Gleason tells us "has probably been quoted more than any other in the history of immigration," has of course been generally cited to celebrate American diversity and the general acceptance of this diversity as forming the basis of a new nation, a new national identity. But today we will look at it with more critical eyes, and note what it does not include as well as what it does: There is no reference to Negroes or blacks or Africans, who then made up a fifth of the American population, or to American Indians, who were then still a vivid and meaningful, on occasion menacing, presence in the colonies. In the course of an examination of the idea of assimilation in American history, we will find many other passages that to our contemporary eyes will express a similarly surprising unconsciousness, or hypocrisy, or unawareness: Today we would cry out, "There are oth- 
ers there you are not talking about! What about them, and what place will they have in the making of the new American?"

The concept of assimilation looked toward Europe: It referred to the expected experience and fate of the stream of immigrants who were a permanent part of American life and consciousness from the time of the first settlements on the Atlantic seaboard to the 1920s, when it was thought (incorrectly) that we were now done with mass immigration of people of varied backgrounds to the United States.

There has been a good deal of discussion of the significance of one major characteristic of the emerging American national consciousness, or, we would say today, the emerging American identity: In many authoritative formulations, from the Declaration of Independence on, the American, the new nationality being formed here, is not defined ethnically, as deriving from an ancient common stock or stocks, as almost all other major modern nations define themselves. I point out as an aside that while the term "identity" is almost essential in any discussion of this emerging American national character, it is a relative latecomer to the discussion. Philip Gleason tells us:

The term "identity" has become indispensable in the discussion of ethnic affairs. Yet it was hardly used at all until the 1950's. The father of the concept, Erik H. Erikson, remarked on its novelty in ... Childhood and Society (1950): "We begin to conceptualize matters of identity ... in a country which attempts to make a super-identity of all the identities imported by its constituent immigrants." In an autobiographical account published 20 years later, Erikson ... quoted this passage and added that the terms "identity" and "identity crisis" seemed to grow out of "the experience of emigration, immigration, and Americanization."

Many could be quoted on this surprising characteristic of American identity and on the avoidance or very limited presence of explicit ethnic reference in the founding documents and in the debates on the revolution and the formation of the union. Despite the facts that the American revolution was fought almost exclusively by men who traced their origins to the British Isles, and primarily to England and that the signers of the Declaration of Independence and the framers of the Constitution were exclusively of this stock, they did not define their Americanness as an ethnic characteristic: They emphasized its dependence on adherence to ideals, to universal principles. Perhaps, as Gleason points out, it was because it was necessary for the 
rebels and revolutionaries to distinguish themselves from the ethnically almost identical country against which they were rebelling.

But in any case, the preference for an ideological formulation of the definition of the American was there at the beginning. Years ago I quoted Hans Kohn, Yehoshua Arieli, and S. M. Lipset on this characteristic of American identity. ${ }^{3}$ One could add other voices. As Gleason writes:

The ideological quality of American national identity was of decisive importance, vis-à-vis the question of immigration and ethnicity. To become an American a person did not have to be of any particular national, linguistic, religious, or ethnic background. All he had to do was to commit himself to the political ideology centered on the abstract ideals of liberty, equality, and republicanism. Thus the universalist ideological character of American nationality meant that it was open to anyone who willed to become an American. ${ }^{4}$

As anyone writing in 1980 must be, he is aware of the exclusions, not remarked on by the writers of those early ringing documents (perhaps exclusions of which they were not conscious) of blacks and Indians, and later, other groups not present at the beginning of the new United States. Even if they were not not specifically excluded, they were not intended to be included in these ringing affirmations of universality.

One could find here and there before the 1940s a few voices of significance who seem to make no exclusion: There was Emerson in 1845: "in this continent-asylum of all nations, - the energy of Irish, Germans, Swedes, Poles, and Cossacks, and all the European tribes,- - of the Africans, and of the Polynesians, - will construct a new race, a new religion, a new state, a new literature, which will be as vigorous as the new Europe which came out of the smelting-pot of the Dark Ages." ${ }^{{ }_{5}}$ There was Whitman. But one can ask even of Emerson, did he mean it? What did he know of Polynesians, after all? And one can ask of the term he introduced to characterize the assimilation of the different elements, the "smelting pot"-later to achieve fame in this discussion in the form of the "melting pot" - was that not too brutal, too strong, a metaphor for what was to be lost, to disappear, in order to make this new race? In the metaphor, the groups were to be more than melted, but rather smelted, as in two or more metals becoming one (the Emerson passage begins with a reference to "Corinthian brass"). But for the moment ignoring the question of whether assimilation was too strong a demand, it is necessary to focus on who was to be assimilated. 
If we look back toward the nineteenth century from the perspective of the present, we can only be surprised at how unconcerned Americans were over the problem of assimilation until the 1890s or so. John Higham has pointed to this oddity, but notes that this unconcern was possible only because other races simply didn't enter into the consideration of the issue. As he writes:

To speak of assimilation as a problem in nineteenth-century America is, in an important sense, to indulge in anachronism. That is because nineteenthcentury Americans seemed for the most part curiously undaunted by, and generally insensitive to, the numerous and sometimes tragic divisions in their society along racial and ethnic lines.... Assimilation was either taken for granted or viewed as inconceivable. For European peoples it was thought to be the natural, almost inevitable, outcome of life in America. For other races assimilation was believed to be largely unattainable and therefore not a source of concern. Only at the end of the century did ethnic mixing arouse a sustained and urgent sense of danger. Only then did large numbers of white Americans come to fear that assimilation was not occurring among major European groups and that it was going too far among other minorities, notably blacks, Orientals, and Jews. ${ }^{6}$

\section{The Americanization Movement}

In almost all the discussions of Americanization or assimilation until about World War II, the participants have only Europeans in mind. This is true whether they favored or opposed assimilation and Americanization efforts. Today's reader of the documents of the great Americanization drive of the second decade of this century will find no reference to blacks, then as now our largest minority. It is as if the turmoil of abolitionism, slavery, the Civil War, Reconstruction, did not exist. All concern was with the "new" immigrants, that is, the mass immigration from Eastern and Southern Europe that brought enormous numbers of different kinds of Europeans from those the nation had become accustomed to. Admittedly one could make the argument that "Americanization," the name of the assimilation movement of the time, could address only those who were not Americans, and were not blacks American-born, and formally citizens? So, one could argue, this was the reason they were ignored in the great debate that finally degenerated into a resurgent Ku Klux Klan and the closing of the gates to the new immigrants. 
Yet when one looks at the aims of the Americanization movement one may well ask, and why not blacks too? The aims of the movement, in its earlier, benign form, were to make the newcomers citizens and encourage them to participate as individuals in politics (as against their domination by urban bosses), to teach them English (and here one main argument was to make them better and safer workers, in view of the huge toll of industrial accidents), to break up immigrant colonies ("distribution," it was called), to teach American customs, which to the Americanizers seemed to mean primarily sanitation and hygiene. All this would make the immigrants better Americans.

One major motivation was concern that the new immigrants would not become good Americans, owing to lack of English, citizenship, and knowledge of American customs. With World War I, to this motivation was added fear of lack of patriotism or disloyalty. But the vigorous advocates of Americanization-social workers and businessmen, a strange mix that nevertheless characterized much of the progressivism of the time-were also trying to plead the case of the new immigrants against those of their countrymen who increasingly favored immigration restriction. The social workers, we know, pled this case out of understanding and sympathy for the new immigrants. The businessmen, we may assume, took the same position primarily out of self-interest, much as the Wall Street Journal of today argues for free immigration. But if these were the aims of the Americanization movement, why were not the blacks included?

Their exclusion is even more striking to the current reader in view of the language of the time, in which ethnic groups are referred to as "races." But the first group that comes to mind today when we speak of "race" was not in the minds of these earnest and energetic advocates of assimilation and Americanization.

Consider one of the most authoritative statements of what was hoped for from Americanization, from a progressive woman social worker who was the heart and soul of the movement, indefatigably organizing committees, conventions, statements, and programs, Frances Kellor:

Americanization is the science of racial relations in America, dealing with the assimilation and amalgamation of diverse races in equity into an integral part of the national life. By "assimilation" is meant the indistinguishable incorporation of the races into the substance of American life. By "amalgamation" is meant so perfect a blend that the absence or imperfection of any of the vital racial elements available, will impair the compound. By "an integral part" is 
meant that, once fused, separation of units is thereafter impossible. By "in equity" is meant impartiality among the races accepted into the blend with no imputations of inferiority and no bestowed favors.?

This is a late statement, made when the movement was taking on a harsher tone, and rather stronger than we would find from most advocates of Americanization (in particular in its emphasis on "amalgamation," which can only mean intermarriage to the point of the indistinguishability of any distinct group), but the point in quoting this statement is that we may take it for granted, in the light of the attitude toward black-white intermarriage that then prevailed, that Frances Kellor simply did not have blacks in mind, despite the continual emphasis on the word "race."

One of the early climaxes of the movement was a great meeting in Philadelphia on May 10, 1915. Woodrow Wilson addressed a huge throngfive thousand newly naturalized citizens, eight thousand previously naturalized, with a chorus of five thousand voices, and the like. He does not use the term "race" in his paean to the all-inclusiveness of America; but all races are clearly implied in his term "the people of the world":

This is the only country in the world which experiences this constant and repeated rebirth. Other countries depend upon the multiplication of their own native people. This country is constantly drinking strength out of new sources by the voluntary association with it of great bodies of strong men and forward-looking women out of other lands.... It is as if humanity had determined to see to it that this great Nation, founded for the benefit of humankind, should not lack for the allegiance of the people of the world. ${ }^{8}$

But we might again ask, where were the blacks? Clearly Wilson did not have them in mind.

This great meeting was the prelude to "Americanization Day" on July 4, 1915, when many mass meetings to welcome new citizens were held all over the country. One of them was in Faneuil Hall in Boston, addressed by Justice Brandeis. He asserted that what was distinctly American is "inclusive brotherhood." America, as against other nations, "has always declared herself for equality of nationalities as well as for equality of individuals. It recognizes racial equality as an essential of full human liberty and true brotherhood. ... It has, therefore, given like welcome to all the peoples of Europe." "The peoples of Europe" is what he has in mind, not blacks.

Most ironically, we find that one of the most active of the postwar Americanization groups was the "Inter-Racial Council." We know what that term 
would have meant had it been used twenty years later. But in 1919 it struck no one as odd, apparently, that it did not refer to blacks at all and it did not include blacks. Among a host of names of leading businessmen and bankers and political dignitaries we find some prominent immigrant names (Dr. Antonio Stella, M. I. Pupin, Gutzon Borglum, Jacob Schiff), but no blacks. ${ }^{10}$

As the Americanization movement began to shift from one befriending the immigrant, bringing him closer together to Americans, to one that seemed increasingly hostile, in which the generous offer of citizenship and full participation became the compulsory demand that the immigrant must learn English and American government, the Carnegie Corporation, trying to defend the earlier openness toward the immigrant, the spirit expressed by Jane Addams and Lillian Wald, sponsored a series of "Americanization Studies." Once again the language in these studies will surprise us in its unconsciousness of the fact that "race" might include other than Europeans.

In James A. Gavit's book, Americans by Choice, on the issue of naturalization, we find again the argument with which we are familiar: The American is not defined ethnically, he is defined by allegiance to an ideology. "The American Has No Racial Marks," one subtitle asserts:

This absence of exclusive racial marks is the distinguishing physical characteristic of the American. True of him as of no other now or ever in the past is the fact that he is, broadly speaking, the product of all races....

We are in the midst of the making of the "American." He does not yet appear what he shall be but one thing is certain, he is not to be of any particular racial type now distinguishable. Saxon, Teuton, Kelt, Latin and Slavto say nothing of any appreciable contribution by yellow and brown races as yet negligible.... - each of the races that we now know on this soil will have its share of "ancestorial" responsibility for the "typical American" that is to be.

The next heading reads, "Not Racial, But Cultural.""

Dealing as he does with naturalization, Gavit cannot, as more celebratory advocates of Americanization can, totally ignore the racial aspect: Naturalization was racially limited. Only whites (and Africans!) could become citizens. He does write:

It is not yet true-perhaps it will be very long before it can be true-that there is absolutely no bar to any person on account of race; for the law and its interpretations exclude from citizenship Chinese, Japanese, and certain people of India not regarded as "white"-although the blacks of Africa are 
expressly admitted. Nevertheless, it may be said broadly that regardless of race, the immigrant can come to America and win his way upon his own merits into the fellowship all the world calls "Americans". ${ }^{12}$

There is no comment on the fact that despite their formal equality as citizens, blacks were not allowed to participate in politics in the South.

We will find a similar liberal and welcoming tone in another volume of the Carnegie Corporation's Americanization series, The Schooling of the Immigrant, by Frank V. Thompson, then superintendent of Boston's public schools. It is mostly concerned with the teaching of English and of American ideals and habits, which are left rather unspecified and vague. The students he has in mind in most of the book are adults who he hopes will become naturalized. When it comes to schoolchildren, the children of immigrants, nothing much is proposed: The author has confidence in the assimilatory powers of the American public school, and while he commends some contemporary distinctive programs for immigrant children (not sufficiently specified to give any clear impression of what they do), he feels Americanization requires little in the way of special adaptation, and what little is required is the teaching of knowledge of American government. He writes: "An astonishing fact about the work of the common school is that Americanization has scarcely been a conscious motive. Americanization has taken place through the schools but it has been an unconscious by-product; ... specifically the teacher has been concerned with the fundamental processes of education and with the fine and industrial arts." He thinks more attention should be paid specifically to "training in citizenship," and notes that teachers receive a good deal of training, and fulfill various requirements for promotion, "but nowhere among these is there a test of acquaintanceship with the problem of Americanization."13

So as regards school children he expresses no great concern; despite the lack of specific attention,

Americanization and citizenship are usual resultants of all school training. The child receives impressions, inspirations, and impulses from the pictures he sees in the classroom, from the stories he reads in his history, from the exercises he attends in the assembly hall, from the celebration of patriotic anniversaries and the salute of the flag. We furnish special classes sometimes for non-English speaking children, but we do so merely for the purpose of enabling these children to enter the regular grades without delay. ${ }^{14}$

All this is very far from what we later came to know as intercultural education, which emphasized education in tolerance, and even farther from the 
present varieties of multiculturalism. There is supreme confidence in the assimilatory powers of American society and its distinctive agent, the public school. No special programs are required aside from the teaching of English and the strengthening of the rather puerile civics courses of the day. Thompson pays no attention to the distinctive culture of European children of different ethnic groups or religions. He does consider whether any distinctive variation for immigrant children in the public education generally provided is necessary, and he is doubtful. As he writes: "It is to our credit that in our schools we have never made invidious comparisons with respect to the children of the immigrant; we have received them on a basis of equality and made them feel that there were no distinctions on account of accidents of birth and circumstance."'15

Nevertheless he does recommend that just as we make special provision for various kinds of "atypical" children, there should be some special provision to take account of the fact that "the majority of immigrant children, while normal with respect to range of mental capacities, do differ in social and economic condition from the children of families settled here for generations. The immigrant child ... frequently suffers from the handicap of a foreign language in the household, and often from the inexperience of his parents in the American environment." What he seems to have in mind is the "steamer classes," common then for newly arrived immigrant children in some large cities. These did not characteristically last for more than a few months. ${ }^{16}$

We see here the characteristic assumption of the period that the assimilation of European children is no very difficult matter and the characteristic silence in regard to black children. Nor is there any reference to Asian children, and yet the question of separate schools for Japanese-American children had been and was an issue in California. Even when Thompson has a section titled "The South Awakened to Illiteracy," his main point is that there are few immigrants in the Deep South and the problem there is the substantial degree of illiteracy among the native population. He may have had blacks as well as whites in mind, though there is no reference to blacks. What centrally concerned him was to encourage tolerance and welcome, and appropriate kinds of assistance, for the European immigrant, adult or child.

As we know, the Americanization movement lost its aspect of welcome and inclusion in the midst of the passions aroused by World War I and the postwar fear of Bolshevism and radicalism. It turned into something harsh and oppressive, in which the issue became less the opportunity to learn English than the insistence that nothing but English be learned; less the gener- 
ous offer of citizenship than the widespread fear of subversion from aliens and naturalized citizens. Americanization developed a bad name among liberals. Insofar as there was still concern for the living and working conditions of immigrants, this became encompassed in a larger liberal movement for improving the conditions of workingmen, a movement that was easily capable of reconciling commitment to the cause of working people with opposition to further immigration. If the word "assimilation" now makes us suspicious, and "Americanization" even more so, it is in part because of the excesses of the 1920s.

\section{The Critics of Assimilationism}

The term "Americanization" is no longer to be found in encyclopedias of the social sciences, ${ }^{17}$ but it does appear in the first great Encyclopedia of the Social Sciences of 1930, and the comment we find there on the fate of Americanization will to some extent explain to us why we do not hear much about it today:

This emphasis on the learning of English and naturalization, together with the unfortunate atmosphere of coercion and condescension in which so many wartime Americanization efforts were conceived, had the effect of bringing the word into a disrepute from which it has never fully recovered. Contributing to the same result, in the period following the war, were the widely expressed fear and suspicion of the immigrant, his frequent indictment as a radical, attempts to suppress his newspapers and organizations, the ignoring of his own culture and aspirations, the charge that certain nationalities and races were inferior and unassimilable, and the use of intimidating slogans. Americanization work too frequently made the assumption that American culture was something already complete which the newcomer must adopt in its entirety. Such attitudes and activities were important factors in promoting restriction of immigration, but they did not advance the assimilation of the immigrants who were already in America. ${ }^{18}$

My point in reciting episodes in the history of Americanization is not to add to the extensive literature that explores the neglect of the key question of the treatment of blacks in American society; nor to argue-which is true-that immigrants were better treated and taken more seriously than blacks from the point of view of their inclusion in American society; nor to attack the Americanization movement for its excesses-all legitimate responses to it. It is to set the stage for something that has also received little attention: that the critics of Americanization and assimilation also had 
nothing or little to say about blacks. However passionate their defense of the contribution to American economy, culture, politics, of immigrants and immigrant groups, however strong their resistance to the demand for assimilation, whatever the arguments they raised against the value of assimilation, the critics of Americanization and assimilation-we can call them for convenience the "cultural pluralists" - had little to say, indeed nothing to say, about adding blacks to the groups who they felt had every right to maintain their separate identity. Maybe they believed blacks should preserve their separate identity, maybe they never thought about the matter: Blacks just never entered into the argument.

There were critics of Americanization, fewer in its earlier more benign form, more when it evolved under the pressures of war into an attack on "hyphenated Americanism," even more when it further evolved into the repression of the postwar years. Thus Americanization became associated with laws restricting immigration, limiting the rights of aliens, and banning teaching in foreign languages (and on occasion even teaching foreign languages) and with harsh administrative actions expelling aliens. A powerful wave of nativist public opinion led to the sharp restriction of further immigration from Europe, and the nation experienced the mass hysteria of the Ku Klux Klan and similar organizations. But it is interesting to note that the few voices critical of extreme Americanization and defensive of cultural pluralism that were then raised, and that we have in recent decades disinterred, had almost nothing to say about blacks. This was true of Randolph Bourne in his advocacy of "Transnational America." It was true of Horace Kallen in his insistence that each group, each "race" in the language of the time, had an inherent genius or character that should not be suppressed but allowed to flower. We search this modest literature in vain for any reference to black Americans. ${ }^{19}$

Thus, when John Dewey spoke to the National Education Association in 1916 to defend the value of cultural pluralism, he did not seem to have blacks in mind. Of course, he was speaking in the context of an attack on the loyalty of European Americans, in the language of the time "hyphenated Americans." Nevertheless, one would have thought America's largest minority might have entered into the discussion. Many groups were mentioned in his talk. The American, Dewey asserts, "is international and interracial in his make-up. He is not American plus Pole or German. But the American is himself Pole-German-English-French-Spanish-Italian-Greek-Irish-Scandinavian-Bohemian-Jew-and so on."20 
One searches Horace M. Kallen's Culture and Democracy in the United States, the fullest statement of the cultural pluralist view of the time, almost in vain for any reference to blacks. They cannot be fully escaped: After all, the introductory chapter is titled "Culture and the Ku Klux Klan," and Negroes are listed as among its targets. There are two other slightly fuller references. In speaking of the spirit of Know-Nothingism, he writes: "What differs from ourselves we spontaneously set upon a different level of value. If it seems to be strong it is called wicked and is feared; if it is regarded as weak, it is called brutish and exploited. Sometimes, as in the attitude toward the negro [sic], the emotions interpenetrate and become a sentiment focalizing the worst qualities of each." In the other passage, he is concerned with whether the current hysteria will wane, the integration of immigrants into American life under a liberal regime will continue (here "integration" clearly does not mean "assimilation"). But it may not happen. The immigrant may be fixed in the inferior economic position he now holds: "One need only cast an eye over the negro-white relations in the South to realize the limit that such a condition would, unchecked, engender." ${ }^{21}$ Perhaps it is reading too much into very little, but one detects in this passage no expectation that there will be much change in the condition of the Negro.

The significance of this episode in the history of American thinking about race and ethnicity is that the argument over assimilation and Americanization evoked by the mass immigration of the period 1880-1924 and by the pressures of World War I simply did not take blacks, let alone Mexican Americans or Asians, into account.

\section{Pluralism and World War II}

When the issue of the relation of the immigrant and immigrant groups to American society emerged again in the late 1930 s, matters were very different. Now the initiating historical circumstance was the rise of Hitler, his racism, and his threat to world peace. In World War I the objective of American leaders who favored the allied powers was to have the immigrant forget the country he came from: Memory and allegiance to one's past country among our largest immigrant groups (Germans, Irish) would not lead to sympathy for the Western Allies, but quite the reverse. If immigrants thought of themselves only as Americans, they would more likely accept alliance with England, the country that was the enemy of their homelands. In the run-up 
to our entry into World War II, matters were somewhat different. While patriotism and Americanism were hardly slighted, it generally served the interests of our national leaders that immigrant groups should remember their pasts and their homelands: So many of them were suffering under Nazi oppression.

But the opposition to Hitler involved considerably more than the strategy of using ethnic background to mobilize Americans against a foreign enemy. Hitler was an ideologist as well as a German nationalist, and his ideology was racism and anti-Semitism. Race now meant-in large measure because of Hitler and his racism-what we today understand as race: physical difference. If we were to fight racism, of course blacks could not be ignored. Mobilization in World War I meant a forceful assimilation and Americanization. Mobilization in World War II meant accentuating our tolerance, our diversity, against the racism and intolerance of Hitler. I do not mean to suggest that it was only the logic involved in the fight against Hitler that made it impossible to ignore blacks in considering the relationship of groups of different ethnic and racial background to American society. Many other changes that had taken place in the America of the New Deal and Franklin D. Roosevelt had brought blacks and their plight to public attention more sharply than in the America of Theodore Roosevelt and Woodrow Wilson, but certainly one factor was that American political and educational leaders wanted to emphasize our tolerance and inclusiveness against Hitler's intolerance and exclusiveness.

Thus as something like "cultural pluralism" began to raise its head again with the coming of Hitler and the fear of a future war, the growing concern was no longer with European immigrants alone, as it was in the buildup to World War I. Americans generally were not much concerned with the loyalty of German Americans, or Italian Americans. Security agencies were worried about German-American adherents of Nazism, about Italian-American adherents of Italian Fascism (much fewer), and most about Japanese Americans, who were the only group to be affected by a World War I-style popular hysteria. So there was a reprise to some extent of World War I concern with immigrant loyalty. Indeed, we even had a revival of something like the Americanization Day spectacles of the earlier period in the creation and brief history of "I am an American Day." But the tone of the new movement was different in some key respects.

First, mass immigration had come to an end, and no one expected it to revive, whatever the needs of persecuted Jews and other groups harried by 
the Nazis. European immigrant groups were already well on the way to assimilation. There was no particular need for a movement to emphasize the learning of English or to speed naturalization. Perhaps this explains the rather benign patriotism of World War II as compared with World War I.

But second, blacks and Hispanic Americans and Asians were now definitely part of the story. Because we were fighting Hitler and his ideology of racial superiority, we had to take into account our own groups of racially defined second-class citizens, all suffering under a weight of legal as well as informal segregation, discrimination, and prejudice. Cultural pluralism, which had been in World War I and its aftermath only the evanescent hope of a few philosophers and journalists, became a sturdy growth, under a new name: intercultural education. The focus of concern began to shift, from European immigrant groups to minorities of color. And in fighting the ideology of race-physical race, biological race-how could we not be concerned with how we treated our racial minorities?

What was to be the fate of assimilation in this new dispensation? Whatever the new degree of tolerance for diversity, it was generally expected assimilation would continue. "Intercultural education," the modest movement of the late 1930s and 1940s that taught tolerance of other groups in the schools, was a far cry from a full-bodied cultural pluralism and presented no resistance to assimilation. It stood for tolerance, not for the maintenance of cultural difference and identity. Indeed, even if the term was not used, assimilation was what the advocates for our largest and most oppressed minority also wanted. ${ }^{22}$

\section{Assimilation and the Sociologists}

The term "assimilation" was a key concept in the thinking of our most important sociologist of race and ethnicity, Robert E. Park, who established at the University of Chicago a strong commitment to questions of race and ethnicity. Park and his colleagues had participated in the Carnegie Americanization studies after World War I that I have referred to. Opponents of forceful Americanization, they nevertheless believed social trends were bringing an inevitable assimilation. They did not decry this: This was the inevitable result, in time, of the meeting of peoples. Park saw that the great problem in the way of assimilation was the blacks.

His 1930 article on assimilation in the Encyclopedia of the Social Sciences perceptively points to this as the stumbling block in the way of assimilation: 
In a vast, varied and cosmopolitan society such as exists in America, the chief obstacle to assimilation seems to be not cultural differences but physical traits.... The Negro, during his three hundred years in this country, has not been assimilated. This is not because he has preserved in America a foreign culture and alien tradition.... No man is so entirely native to the soil.... To say the Negro is not assimilated means no more than to say that he is still regarded in some sense a stranger, a representative of an alien race.... This distinction which sets him apart from the rest of the population is real, but is not based upon cultural traits but upon physical and racial characteristics.

\section{As for Europeans:}

The ease and rapidity with which aliens have been able to take over American customs and manners have enabled the United States to digest every sort of normal human difference, with the exception of the purely external ones like that of the color of the skin. ${ }^{23}$

Park saw the key problem for assimilation: it was race. Black intellectuals and leaders were of course also aware that assimilation, as process or ideal, was leaving them out. They were not even participants in the debate over assimilation and Americanization. Nevertheless, in striving for the rights that would make them equal to white Americans, in aiming at a condition in which no distinction would be made between white and black Americans, they in effect were lined up with those who wanted to assimilate or integrate the immigrant. They saw no good reason for the maintenance of group distinctiveness in America. What Americanizers considered ideal for immigrants was what blacks considered ideal for themselves. Black leaders were not asking to be part of that orchestra of difference that Horace Kallen envisaged as the ideal for America. (In fact, black culture was sturdily established and maintained its distinctiveness with no widespread intentional effort or intention to do so, but this came naturally, so to speak, and owed nothing to the demands and hopes of black leaders.) American liberals in general, who supported black aims, also saw no good argument in principle against assimilation for all groups.

Park had set forth a scheme that became quite influential in sociology: Groups in contact moved through various phases, such as conflict and accommodation, ending in assimilation. Despite the growing attention to the plight of blacks during the 1930s and 1940s, an attention encouraged by white and black liberal scholars' important foundation-sponsored research and by key legal cases, there was little challenge to the expectation that assimilation 
or something like it — the term "integration" became popular-was the desirable solution to the American dilemma. Certainly no liberal and no black leader favored the continuation of segregation. No significant black leader favored separatism. Garvey's "Back to Africa" was an exotic oddity, and the American Communists' temporary advocacy of a separate black state in the South an even greater oddity. Garveyism reflected more the deep frustration of the American black over exclusion from American society than any positive commitment to the maintenance of a separate black culture. Until the late 1960s, there was no challenge to the assimilationist stance of sociologists who studied race and ethnicity and of black scholars and leaders.

Park and his leading students, while they did not put their preferences forth sharply, assumed assimilation not only was inevitable but would be all for the best. Thus, Louis Wirth, who was the chief successor to Park, made clear in his book on American Jews, The Ghetto, that his preference was for assimilation: The Jew continued to exist only because of prejudice and discrimination; all the reactions of the Jew to this antagonism were humanly limiting; and assimilation, which to be sure required lowering the barriers others placed in the way of assimilation, was the desirable end result of the interaction of Jews and non-Jews in contemporary society. ${ }^{24}$

The central work on the black condition in the United States in the 1940s, Gunnar Myrdal's An American Dilemma, ${ }^{25}$ which expressed not only his views but to some degree those of his black collaborators, major black scholars and intellectuals of the times, could also be described as assimilationist. A number of these collaborators were Marxists (Myrdal of course was not) and as such saw racial and ethnic difference as a survival, something that would in time be overcome by the development of class consciousness, bringing together blacks and whites on the basis of class interest. ${ }^{26}$

The major works of E. Franklin Frazier on the black family could also be described as assimilationist. Insofar as the black family was stable and puritanical it was good-that was unquestioned. There was no hint that it was desirable that any distinctive cultural feature should survive as specifically Negro or black, or that there should be any effort to seek such features.

The best-informed, most liberal, and most sympathetic analysts of the ethnic and racial scene in the 1930s and 1940s saw assimilation as a desirable consequence of the reduction of prejudice and discrimination. Blacks wanted to live under circumstances no different from those whites lived under, and under these circumstances they would not be different from other Americans. It was rare to find among black intellectuals and political 
leaders any notion that some distinctive black culture or social practices must be protected and retained. In the face of the overwhelming task of dealing with white prejudice and discrimination, the issue of a distinctive black culture could not take a high place on any black agenda.

Although it was clear that blacks could never because of race be indistinguishable from whites, it was desirable that they become culturally, socially, economically, and politically assimilated, that they be simply Americans with dark skins. Until the 1960s, scarcely any black leader or intellectual diverged from this view. Their demand was that all public bodies, agencies of government, schools, and colleges and all private agencies that affected individual circumstances, including banks, businesses, housing producers, and landlords, be color-blind.

Among the white immigrant groups, or, to label them more properly, ethnic groups, for such they became as they maintained some degree of group cohesion and identity with the reduction in the numbers of the foreign-born, one could find the upholders of the ethnic conscience and consciousness, those who established and maintained schools, churches, philanthropic and civic organizations, insurance societies, social groups. But except among those whose direct interest was in maintaining this organizational network and the jobs it offered, these were regarded by the members of ethnic groups themselves as survivals, fated to fall away as acculturation and assimilation progressed. There was no more 100-percent American than the children of immigrants, the second generation.

Acculturation and assimilation, if not the cruder "Americanization," was thus generally accepted as the way America was going and should go. This prospect was favored by old Americans, regardless of their attitudes to the newer Americans, and by the immigrants of the great migration of the end of the nineteenth and beginning of the twentieth centuries and their children. Nativists as well as liberals most sympathetic to the newer Americans accepted the inevitability and desirability of assimilation.

Of course, as we know, we are now very far from all this. The voices of opposition to assimilation burst out in the late 1960s and have gone through many permutations since. Bland "intercultural education" has succumbed to the rather more forceful "multicultural education"- though that too comes in all brands, from the mildest recognition of differences to a rather hysterical and irrational Afrocentrism. We even had, in the late 1960s and 1970s, a brief explosion of revived ethnic assertiveness among white European ethnic groups, the heirs of the immigrants of the early decades of the 
century. It could not survive; assimilation had gone too far. We have a few modest programs in Italian-American studies, and a sturdier growth of Jewish programs, sturdier because Jewish programs are able to draw not only on ethnic attachments that tend to be stronger than those of most white Europeans, but also on religion, which creates a robust body of institutions to parallel the purely ethnic, and which has greater prestige and receives more tolerance in the American setting.

We come now to our question: Is assimilation then dead? The word may be dead, the concept may be disreputable; the reality continues to flourish. As so many observers in the past have noted, assimilation in the United States is not dependent on public ideology, on school curricula, on public approbation: Factors in social and economic and cultural life foster it, and it proceeds apace. Read Lewis was right when, in his now more than sixtyyears-old article on "Americanization" in the Encyclopedia of the Social Sciences, he wrote:

Important as these conscious efforts are toward Americanization, they rep-
resent only a part of the social forces which play continuously upon the
immigrant and determine the degree and rapidity of his assimilation. A con-
spicuous force which makes for adjustment is the urge to material success,
which makes the immigrant adapt himself to American ways of work and
business. This usually involves learning the English language as quickly as
possible. Standardizing forces such as national advertisements, ten-cent store
products, movies, radio and the tabloid press play also upon the immigrant. ${ }^{27}$

Correct for inflation, add television, baseball, football, basketball, and so on, and it is clear the forces pressing assimilation have not lost power.

Call it "acculturation" if you will. But assimilation in its least deniable and strongest form, what was once called "amalgamation," also proceeds apace. The rates of intermarriage among all European ethnic groups are very high. ${ }^{28}$ Even Jews, who have a strong cultural and religious bar against intermarriage, and who maintained a rather low rate of intermarriage until the last two or three decades, now show very high rates for individuals marrying outside the group. With such high rates, it is hardly clear to any individual what his or her ethnic group is and how it is to be defined. In answer to the question "What is this person's ancestry," asked in the census, most Americans give multiple ancestries. ${ }^{29}$ Mary Waters, in Ethnic Options, shows how thin any sense of ethnicity among Americans of European origin has become. ${ }^{30}$ 
But there is the great exception. If intermarriage is taken as key evidence for powerful assimilatory forces, then blacks are not subject to these forces to the same degree as others. Hispanic groups and Asian groups, despite the recency of immigration of so many of them, and thus the greater power of family and group attachment, show rates of intermarriage approaching the levels of Europeans. ${ }^{31}$ Blacks stand apart, with very low rates of intermarriage, rising slowly. They stand apart too in the degree of residential segregation. ${ }^{32}$ Thirty years of effort, public and private, assisted by antidiscrimination law and a substantial rise in black earnings, have made little impact on this pattern.

Whatever the causes, the apartness is real. And it is this that feeds multiculturalism. For one group, assimilation, by some key measures, has certainly failed. For others, multicultural education may be a matter of sentiment. But most black children do attend black-majority schools. Most live in black neighborhoods. Why should not multiculturalism, in the form of the examination of group history, characteristics, problems, become compelling as one way of understanding one's situation, perhaps overcoming it? The large statements asserting that the American national ideal is inclusion, assimilation, understandably will ring false to many, despite the commitment of most black intellectuals and political leaders to integration.

For Hispanics and Asian Americans, marked in varying degree by race, it is in large measure a matter of choice, their choice, just how they will define their place in American society. We see elements in these groups who, in their support of bilingual education and other foreign-language rights, want to establish or preserve an institutional base for a separate identity that may maintain some resistance to the forces of assimilation. For blacks too there are choices - we see the existence of choices in the writings of black intellectuals who oppose the stronger tendencies of multiculturalism. But the difference that separates blacks from whites, and even from other groups "of color" that have undergone a history of discrimination and prejudice in this country, is not to be denied. This is the most powerful force arguing for multiculturalism and for resistance to the assimilatory trends of American education and of American society.

\section{Notes}

1. J. Hector St. John [Michel-Guillaume-Jean de] Crèvecoeur, Letters from an American Farmer, as quoted in Philip Gleason, "American Identity and Americanization," in 
Harvard Encyclopedia of American Ethnic Groups (Cambridge, Mass.: Harvard University Press, 1980), 33.

2. Gleason, 31.

3. Nathan Glazer, Affirmative Discrimination (New York: Basic Books, 1975).

4. Gleason, 32.

5. Harold J. Abramson, "Assimilation and Pluralism," in Harvard Encyclopedia of American Ethnic Groups, 152.

6. John Higham, Send These to Me: Immigrants in Urban America, revised edition (Baltimore: Johns Hopkins University Press, 1984), 175.

7. Frances A. Kellor, "What is Americanization?" Yale Review, January 1919, as reprinted in Philip Davis, Immigration and Americanization; Selected Readings (Boston: Ginn, 1920), 625-26.

8. Davis, 612; for a description of the meeting, see Edward George Hartman, The Movement to Americanize the Immigrant (New York: AMS Press, 1967), $11 \mathrm{n}$.

9. Davis, 642-43.

10. Hartman, 220-21.

11. James A. Gavit, Americans by Choice (New York: Harper, 1922), 10, 11-12.

12. Gavit, 7-8.

13. Frank V. Thompson, Schooling of the Immigrant (New York, Harper and Brothers, 1920), 15-16.

14. Thompson, 16.

15. Thompson, 73 .

16. Thompson, 74, 118.

17. Nor can we find what was once a key sociological concept, "assimilation," among the entries in the recent four-volume Encyclopedia of Sociology by C. F. and M. L. Borgatta (New York: Macmillan, 1992).

18. Read Lewis, "Americanization," Encyclopedia of the Social Sciences, vol. 2 (New York: Macmillan, 1930), 33.

19. John Higham was perhaps the first to forcefully note the "fatal elision" of blacks from Horace Kallen's American orchestra of diverse ethnic and racial voices. See Send These to Me, 1st ed. (New York, Atheneum, 1975), 208.

20. John Dewey, as quoted in Horace Kallen, Culture and Democracy in the United States (New York: Boni and Liveright, 1924), 131-32.

21. Kallen, 127, 165.

22. For a characterization of the movement, see Nathan Glazer, Ethnic Dilemmas, 1964-1982 (Cambridge, Mass.: Harvard University Press, 1983), 104-8.

23. Robert E. Park, "Assimilation," Encyclopedia of the Social Sciences, 282.

24. Louis Wirth, The Ghetto (Chicago, Ill.: University of Chicago Press, 1928).

25. Gunnar Myrdal, An American Dilemma (New York: Harper, 1944).

26. See, for example, Brian Urquhart, Ralph Bunche: An American Life (New York: W. W. Norton, 1993), 57, and elsewhere for a mainline black leader's position on this matter. 
27. Lewis, 34 .

28. Stanley Lieberson and Mary Waters, From Many Strands: Ethnic and Racial Groups in Contemporary America (New York: Russell Sage Press, 1988), ch. 6.

29. Lieberson and Waters, 45.

30. Mary Waters, Ethnic Options (Berkeley, California: California University Press, 1990).

31. Lieberson and Waters, 182.

32. Douglas S. Massey and Nancy A. Denton, American Apartheid (Cambridge, Mass.: Harvard University Press, 1993). 


\title{
Chapter 2 \\ The Limits of Pluralism
}

\author{
K. Anthony Appiah
}

\begin{abstract}
It is, of course, true that the African identity is still in the making. There isn't a final identity that is African. But, at the same time, there is an identity coming into existence. And it has a certain context and a certain meaning. Because if somebody meets me, say, in a shop in Cambridge, he says "Are you from Africa?" Which means that Africa means something to some people. Each of these tags has a meaning, and a penalty and a responsibility.

— Chinua Achebe (1982)
\end{abstract}

There is an Akan proverb, from my home in Asante in Ghana, that says: Aban begu a, efiri yam. Proverbs are notoriously difficult to interpret, and thus also to translate. But this one means, roughly, that if the state is going to collapse, it will be from the belly. ${ }^{1}$ The idea, of course, is that states collapse from within; and the proverb is used to express the sentiment that people suffer as a result of their own weaknesses, not from the attacks of others. It is a rhetoric familiar enough, these days, here in the United States. In the latest episodes of American jeremiad-truly the longest-running series in our history-it is being suggested that having "won the cold war," we have set out to destroy ourselves from within. American society is being destroyed not by drugs and poverty and political bungling but by multiculturalists intent on schism: here, then, is a society collapsing from the belly.

Naturally, I do not believe it. In a world that contains Bosnia-Herzegovina and Belfast and Beirut and East Timor and Sri Lanka, events such as the Los Angeles riots (multicultural riots, if ever there were any) do not convince me that the United States is being destroyed by an excess of ethnicity. I am not of Arthur Schlesinger's party.

Those of us born and raised elsewhere, but happy to be living here in the United States, often find one thing above all odd in our adopted home, a tradition as old in America as American jeremiad, as old in the world as 
nationalism, namely, this country's imagination of itself as so new a creature on God's earth that it cannot learn from others. This exceptionalism flows, in part, from a general ignorance of others that it is the aim of one part of the multicultural movement to correct. So I begin by talking about pluralism and identity in Africa in order to draw some lessons (both positive and negative) about the way we have dealt with our ethno-regional complications.

The cultural life of most of black Africa remained largely unaffected by European ideas until the last years of the nineteenth century; and most cultures began our own century with ways of life formed very little by direct contact with Europe. As a result, European cultural influence in Africa before the twentieth century was extremely limited. Deliberate attempts at changethrough missionary activity or the establishment of Western schools-and unintended influence-through contact with explorers and colonizers in the interior and trading posts on the coasts-produced small enclaves of Europeanized Africans; but the major cultural impact of Europe is largely a product of the period since the First World War.

To understand the variety of Africa's contemporary cultures, therefore, we need first to recall the variety of the precolonial cultures. Differences in colonial experience have also played their part in shaping the continent's diversities; but even identical colonial policies identically implemented working on the very different cultural materials would surely have produced widely varying results.

No doubt at a certain abstract level we can find generalizations that hold true of most of black Africa before European conquest. It is a familiar idea in African historiography that Africa was the last continent in the Old World with an "uncaptured" peasantry, largely able to use land without the supervision of feudal overlords and able, if they chose, to market their products through a complex system of trading networks. ${ }^{3}$ While European ruling classes were living off the surplus of peasants and the newly developing industrial working class, African rulers were essentially living off taxes on trade. But if we could have traveled through Africa's many cultures in those years-from the small groups of Bushman hunter-gatherers, with their Stone Age materials, to the Hausa kingdoms, rich in worked metal-we should have felt in every place profoundly different impulses, ideas, and forms of life. To speak of an African identity in the nineteenth century-if an identity is a coalescence of mutually responsive (if sometimes conflicting) modes of conduct, habits of thought, and patterns of evaluation; in 
short, a coherent kind of human social psychology — would have been "to give to aery nothing a local habitation and a name."

Yet there is no doubt that now, a century later, an African identity is coming into being. I have argued elsewhere ${ }^{4}$ that this identity is a new thing; that it is, in part, the product of a colonial history; and that the bases through which it has largely so far been theorized-race, a common historical experience, a shared metaphysics-presuppose falsehoods too serious for us to ignore.

Now, every human identity is constructed, historical; every one has its share of false presuppositions, of the errors and inaccuracies that courtesy calls "myth," religion "heresy," and science "magic." Invented histories, invented biologies, invented cultural affinities come with every identity; each is a kind of role that has to be scripted, structured by conventions of narrative to which the world never quite manages to conform.

Often those who say this-who deny the biological reality of races or the literal truth of our national fictions - are treated by nationalists and "racemen" as if they are proposing genocide or the destruction of nations, as if in saying that there is literally no Negro race, one were obliterating all those who claim to be Negroes, in doubting the story of Okomfo Anokye one were repudiating the Asante nation. ${ }^{5}$ This is an unhelpful hyperbole; but it is certainly true that there must be contexts in which a statement of these truths is politically inopportune. I am enough of a scholar to feel drawn to truth telling, though the heavens fall; enough of a political animal to recognize that there are places where the truth does more harm than good.

But, so far as I can see, we do not have to choose between these impulses: there is no reason to believe that racism is always - or even usually-advanced by denying the existence of races; and, though there is some reason to suspect that those who resist legal remedies for the history of racism might use the nonexistence of races to argue in the United States, for example, against affirmative action, that strategy is, as a matter of logic, easily opposed. For the existence of racism does not require the existence of races; and, we can add, nations are real enough, however invented their traditions. ${ }^{6}$

To raise the issue of whether these truths are truths to be uttered is to be forced, however, to face squarely the real political question, itself as old as political philosophy, of when we should endorse the noble lie. In the real world of practical politics, of everyday alliances and popular mobilizations, a rejection of races and nations in theory can be part of a program for coherent political practice only if we can show more than that the Black 
race - or the Shona tribe or any of the other modes of self-invention that Africa has inherited - fits the common pattern of relying on less than the literal truth. We would need to show not that race and national history are falsehoods, but that they are useless falsehoods at best or dangerous ones at worst: that another set of stories will build us identities through which we can make more productive alliances.

The problem, of course, is that group identity seems to work best when it is seen by its members as natural, as "real." Pan-Africanism, black solidarity, can be an important force with real political benefits; but it doesn't work without its attendant mystifications. (Nor, to turn to the other obvious example, is feminism without its occasional risks and mystifications either.) Recognizing the constructedness of the history of identities has seemed to many incompatible with taking these new identities with the seriousness they have for those who invent—or, as they would no doubt rather say, discover-and possess them. In sum, the demands of agency seem always - in the real world of politics-to entail a misrecognition of its genesis; you cannot build alliances without mystifications and mythologies. And so I would like to explore the ways in which what is productive in African forms of identity politics can be fruitfully understood by those of us whose positions as intellectuals-as searchers after truth-make it impossible for us to live through the falsehoods of race and tribe and nation; and whose understanding of history makes us skeptical, at the same time, that nationalism and racial solidarity can do the good that they can do without the attendant evils of racism - and other particularisms; without the warring of nations.

I have argued often against the forms of racism implicit in much PanAfricanist talk. ${ }^{8}$ But such objections to a biologically rooted conception of race may still seem all too theoretical: if Africans can get together around the idea of the Black Person, if they can create through this notion productive alliances with African Americans and people of African descent in Europe and the Caribbean, surely these theoretical objections should pale in the light of the practical value of these alliances. But there is every reason to doubt that they can. Within Africa-in the Organization of African Unity (OAU), in the Sudan, in Mauritania - racialization has produced arbitrary boundaries and exacerbated tensions; in the diaspora alliances with other peoples of color, as victims of racism-people of South Asian descent in England, Hispanics in the United States, "Arabs" in France, Turks in Germany-have proved essential. 
In short, I think it is clear enough that a biologically rooted conception of race is both dangerous in practice and misleading in theory: African unity, African identity, need securer foundations than race.

The passage from Achebe with which I began continues in these words: "All these tags, unfortunately for the black man, are tags of disability." But it seems to me that they are not so much labels of disability as disabling labels; which is, in essence, my complaint against Africa as a racial mythology—-the identity of Alexander Crummell and W. E. B. Du Bois and the older Pan-Africanists; against Africa as a shared metaphysics or a fancied past of shared glories-the identity of the "Afrocentrists." These complaints can be briskly summarized.

"Race" disables us because it proposes as a basis for common action the illusion that black (and white and yellow) people are fundamentally allied by nature and, thus, without effort; it leaves us unprepared, therefore, to handle the "intraracial" conflicts that arise from the very different situations of black (and white and yellow) people in different parts of the economy and of the world.

A retreat to African metaphysical traditions (exemplified, for example, in the powerful rhetoric of Wole Soyink $\mathrm{a}^{10}$ ) disables us because it founds our unity in gods who have not served us well in our dealings with the worldSoyinka never defends what he calls the "African World" against the charge made by the Ghanaian philosopher Kwasi Wiredu, that since people die daily in Ghana because they prefer traditional herbal remedies to Western medicines, "Any inclination to glorify the unanalytical [i.e., the traditional] cast of mind is not just retrograde; it is tragic." pantheon a powerful literary resource: but he cannot explain why Christianity and Islam have so widely displaced the old gods or why an image of the West has so powerful a hold on the contemporary Yoruba imagination; nor can his myth making offer us the resources for creating economies and polities adequate to our various places in the world.

And the Afrocentrists-like all who have chosen to root Africa's modern identity in an imaginary history-require us to see the past as the moment of wholeness and unity; tie us to the values and beliefs of the past; and thus divert us from the problems of the present and the hopes of the future.

If an African identity is to empower us, so it seems to me, what is required is not so much that we throw out falsehood but that we acknowledge first of all that race and history and metaphysics do not enforce an identity: that we must choose, within broad limits set by ecological, political, and economic realities, what it will mean to be African in the coming years. 
I do not want to be misunderstood. We are Africans already. And we can give numerous examples from multiple domains of what our being African means. We have, for example, in the OAU and the African Development Bank, and in such regional organizations as the Southern African Development Coordination Conference (SADCC) and the Economic Community of West African States (ECOWAS), as well as in the African caucuses of the agencies of the United Nations and the World Bank, African institutions. At the Olympics and the Commonwealth games, athletes from African countries are seen as Africans by the world-and, perhaps more importantly, by each other. Being African already has "a certain context and a certain meaning."

But, as Achebe suggests, that meaning is not always one we can be happy with; and that identity is one we must continue to reshape. And in thinking about how we are to reshape it, we would do well to remember that the African identity is, for its bearers, only one among many. Like all identities, institutionalized before anyone has permanently fixed a single meaning for them-like the German identity at the beginning of this century, or the American in the latter eighteenth century, or the Indian identity at independence so few years ago - being African is, for its bearers, one among other salient modes of being, all of which have to be constantly fought for and rethought. And indeed, in Africa, it is another of these identities that provides one of the most useful models for such rethinking; it is a model that draws on other identities central to contemporary life in the subcontinent: namely, the constantly shifting redefinition of "tribal" identities to meet the economic and political exigencies of the modern world.

Once more, let me quote Achebe:

The duration of awareness, of consciousness of an identity, has really very little to do with how deep it is. You can suddenly become aware of an identity which you have been suffering from for a long time without knowing. For instance, take the Igbo people. In my area, historically, they did not see themselves as Igbo. They saw themselves as people from this village or that village. In fact in some places "Igbo" was a word of abuse; they were the "other" people, down in the bush. And yet, after the experience of the Biafran War, during a period of two years, it became a very powerful consciousness. But it was real all the time. They spoke the same language, called "Igbo", even though they were not using that identity in any way. But the moment came when this identity became very very powerful ... and over a very short period. ${ }^{12}$ 
A short period it was; and also a tragic one. The Nigerian Civil War defined an Igbo identity: it did so in complex ways, which grew out of the development of a common Igbo identity in colonial Nigeria, an identity that created the Igbo traders in the cities of northern Nigeria as an identifiable object of assault in the period that led up to the invention of Biafra.

Recognizing Igbo identity as a new thing is not a way of privileging other Nigerian identities: each of the three central ethnic identities of modern political life-Hausa-Fulani, Yoruba, Igbo-is a product of the rough-and-tumble of the transition through colonial to postcolonial status. David Laitin has pointed out that "the idea that there was a single Hausa-Fulani tribe . . w was largely a political claim of the NPC [Northern Peoples' Congress] in their battle against the South" while "many elders intimately involved in rural Yoruba society today recall that, as late as the 1930s, 'Yoruba' was not a common form of political identification." ${ }^{13}$ Nnamdi Azikiwe-one of the key figures in the construction of Nigerian nationalism - was extremely popular (as Laitin also points out) in Yoruba Lagos, where "he edited his nationalist newspaper, the West African Pilot. It was only subsequent events that led him to be defined in Nigeria as an Igbo leader." ${ }^{14}$ Yet Nigerian politics — and the more everyday economy of ordinary personal relations - is oriented along such axes; and only very occasionally does the fact float into view that even these three problematic identities account for at most seven out of ten Nigerians.

And the story is repeated, even in places where it was not drawn in lines of blood. As Johannes Fabian has observed, the powerful Lingala and Swahili-speaking identities of modern Zaire exist "because spheres of political and economic interest were established before the Belgians took full control, and continued to inform relations between regions under colonial rule." ${ }^{15}$ Modern Ghana witnesses the development of an Akan identity, as speakers of the three major regional dialects of Twi-Asante, Fante, Akuapem-organize themselves into a corporation against an (equally novel) Ewe unity. ${ }^{16}$

When it is not the "tribe" that is invested with new uses and meanings, it is religion. Yet the idea that Nigeria is composed of a Muslim north, a Christian south, and a mosaic of "pagan" holdovers is as inaccurate as the picture of three historic tribal identities. Two out of every five southern Yoruba people are Muslim; and, as Laitin tells us:

Many northern groups, especially in what are today Benue, Plateau, Gongola, and Kwara states, are largely Christian. When the leaders of Biafra 
tried to convince the world that they were oppressed by northern Muslims, ignorant foreigners (including the pope) believed them. ... But the Nigerian army ... was led by a northern Christian. ${ }^{17}$

It is as useless here, as in the case of race, to point out in each case that the tribe or the religion is, like all social identities, based on an idealizing fiction, for life in Nigeria or in Zaire has come to be lived through that idealization; the Igbo identity is real because Nigerians believe in it, the Shona identity because Zimbabweans have given it meaning. The rhetoric of a Muslim north and a Christian south structured political discussions in the period before Nigerian independence; but it was equally important in the debates about instituting a Muslim court of appeals in the draft constitution of 1976; and it could be found, for example, in many an article in the Nigerian press as electoral registration for a new civilian era began in July 1989.

There are, I think, three crucial lessons for us in the United States in these cases. First, identities are complex and multiple and grow out of a history of changing responses to economic, political, and cultural forces, almost always in opposition to other identities. Second, they flourish despite what I earlier called our "misrecognition" of their origins; despite, that is, their roots in myths and in lies. And third, there is, in consequence, no large place for reason in the construction-as opposed to the study and the managementof identities. One temptation, then, for those who see the centrality of these fictions in our lives, is to leave reason behind: to celebrate and endorse those identities that seem at the moment to offer the best hope of advancing our other goals, and to keep silence about the lies and the myths. But, as I said earlier, intellectuals do not easily neglect the truth, and, all things considered, our societies profit, in my view, from the institutionalization of this imperative in the academy. So it is important for us to continue trying to tell our truths. But the facts I have been rehearsing should imbue us all with a strong sense of the marginality of such work to the central issue of the resistance to racism and ethnic violence - and to sexism, and to the other structures of difference that shape the world of power; and they should force upon us the clear realization that the real battle is not being fought in the academy. As the fires raged in Los Angeles, it seemed oddly irrelevant to fuss about racial ideologies: the solutions are the conquest of drugs and despair, new jobs, better education, more credit, and so many other more practical steps. And yet, as we all know, the shape of our world (the shape of modern 
Africa) is in large part the product, often the unintended and unanticipated product, of theories; even the most vulgar of Marxists will have to admit that economic interests operate through ideologies. We cannot change the world simply by evidence and reasoning, but we surely cannot change it without them either.

What we in the academy can contribute-even if only slowly and marginally - is a disruption of the discourse of "racial" and "tribal" differences. For, in my perfectly unoriginal opinion, the reality of these many competing identities in Africa today plays into the hands of the very exploiters whose shackles we are trying to escape. "Race" in Europe and "tribe" in Africa are central to the way in which the objective interests of the worst-off are distorted. The analogous point for African Americans was recognized long ago by Du Bois. ${ }^{18}$ Du Bois argued in Black Reconstruction that racist ideology had essentially blocked the formation of a significant labor movement in the United States; for such a movement would have required the collaboration of the nine million ex-slave and white peasant workers of the South. ${ }^{19}$ It is, in other words, because the categories of difference often cut across our economic interests that they operate to blind us to them. What binds the middle-class African American to dark-skinned fellow citizens downtown is not economic interest, but racism and the cultural products of resistance to it that are shared across (much of) African-American culture.

I have been arguing, in effect, that the political meanings of identities are historically and geographically relative. Because the value of identities is thus relative, we must argue for and against them case by case. And given the current situation in Africa, I think it remains true that Pan-Africanism-as the project of a continental fraternity and sorority, not as the project of a racialized Negro nationalism - however false or muddled its theoretical roots, can be a progressive force. It is as fellow Africans that Ghanaian diplomats (my father among them) interceded between the warring nationalist parties in Rhodesia under the Unilateral Declaration of Independence; as fellow Africans that OAU teams can mediate regional conflicts; as fellow Africans that the human rights assessors organized under the OAU's Banjul Declaration can intercede for citizens of African states against the excesses of our governments. If there is to be hope, too, for a Pan-Africanism of the African diaspora once it, too, is released from bondage to racial ideologies (alongside the many bases of alliance available to Africa's peoples in their political and cultural struggles), it is crucial that we recognize the independence, once "Negro" nationalism is gone, of the Pan-Africanism of the diaspora and the 
Pan-Africanism of the continent. It is, I believe, in the exploration of these issues, these possibilities, that the future of an intellectually reinvigorated Pan-Africanism lies.

Informed by these African histories, I am impressed by a simple point of contrast: ethnic variety in the United States is simply not the real resource for resistance to the state and its processes of unification that it can be in my homeland of Ghana and most other parts of Africa and Asia. Africa's societies are multicultural in a much stronger sense than the United States is, and that makes it interesting to compare the reality of Africa with the rhetoric of American multiculturalism.

I am not much one for "isms"; and talk of multiculturalism makes me as nervous as much of the other talk of "isms" that surrounds us. Multiculturalism sounds like the name of an ideology, a single agenda, a unified political vision. If there is such a unified ideology out there, I certainly don't know what it is. What I do know is that-in at least one sense of the much-abused word "culture"-we live in a society of many cultures, a multicultural society.

The idea of "culture" is much abused because it is so elastic. But we can reduce it to some kind of order by identifying a spectrum that begins with the most basic sense of the term - the anthropologist's sense - in which culture means all the ideas and practices that are shared by a social group, and ends with what we call "high" culture- the critical notion of culture-which picks from among those ideas and practices a subset that requires in both producers and consumers the greatest training or the most individual skill. The habit of shaking hands at meetings belongs to culture in the anthropologist's sense; Sandro Botticelli and Martin Buber and Count Basie belong to culture in the critical sense.

No one is likely to make much fuss about the fact that a society is multicultural in the critic's sense. For, in this sense, most large-scale societies have been multicultural. Once you have division of labor and social stratification, there will be people who do and people who don't know about music and literature and pottery and painting; if we call all these specialized spheres together "high" culture, then everyone will participate in the high culture to varying degrees, and there are likely to be subgroups (opera lovers, say, or dedicated movie-goers, or lovers of poetry or rap) who share significant practices and ideas with each other that are not shared with everyone else.

If being multicultural is a problem, it is because societies are multicultural in the anthropological sense, pace those who seem preoccupied with 
stopping multiculturalism at the National Endowment for the Humanities or National Endowment for the Arts, but the problems created by our many cultures largely lie elsewhere.

Culture in the anthropologist's sense is what a social group has socially in common: it is what we teach our children; and in teaching them, we make them members of our social group. By definition, therefore, culture in this sense is shared; it is the social bottom line. It includes language and table manners, religious ideas, moral values. With this idea of culture goes the idea of a subculture: people who share not just the common ideas and practices of the whole social group, but also more specific other practices and values as well.

I say "social group" because a single society, a group of persons living together in a common state, under common authorities, need not have a common culture. There is no single shared body of ideas and practices in most contemporary African states: there is, as we have learned so sadly in recent months, no such shared culture in Bosnia and Herzegovina. And I think it is fair to say that there is not now and there has never been such a shared culture in the United States.

The reason is simple: the United States has always been multilingual, and has always had minorities who did not speak or understand English. It has always had a plurality of religious traditions; beginning with Native American religions and Puritans and Catholics and including now many varieties of Judaism, Islam, Buddhism, Jainism, Taoism, Bahai ... and so on. And Americans have always differed significantly even among those who do speak English, from North to South and East to West, and from country to city, in customs of greeting, notions of civility, and a whole host of other ways.

At the same time, it has also always been true that there was a dominant culture in these United States. It was Christian, it spoke English, and it identified with the high cultural traditions of Europe, and more particularly of England. And, until recently, when people spoke approvingly of American culture, this is what they meant. (When they spoke disapprovingly of American culture, especially in Europe, they meant the popular culture of Hollywood, Coca-Cola, and bubble gum.)

As public education has expanded in the United States, America's citizens, and especially those citizens educated in public elementary schools in this country, have come to share a body of historical knowledge and an understanding of the American political system. And it is increasingly true that whatever other languages children in this country speak, they speak and understand English, and they watch many of the same television programs 
and listen to much of the same music. In that sense, most young Americans have a shared culture based in a whole variety of kinds of English; but it is no longer that older Christian, Anglo-Saxon tradition that used to be called American culture.

The outlines of this common culture, to which only very few Americans are external, are somewhat blurry. But it includes, for example, in its practices, baseball; in its ideas, democracy; in its arts, rap music and music videos and many movies. This culture is to a large extent, as I have implied, the product of schools and of the media. But even those who share this common culture - the shared cultural literacy of E. D. Hirsch, let us say-live in subcultures of language, religion, family organization, and political assumptions. And, more than this, most who are black and Hispanic have, irrespective of their incomes, radically different experiences and expectations of the state. If anyone did not believe this before, surely every sane person recognizes this after the Rodney King and O. J. Simpson verdicts and the racially divided responses to each.

Now I take it that multiculturalism is meant to be the name of a response to these familiar facts: that it is meant to be an approach to education and to public culture that acknowledges the diversity of cultures and subcultures in the United States and that proposes to deal with that diversity in some other way than by imposing the values and ideas of the hitherto dominant AngloSaxon cultural tradition. That, I think, is the common core of all the things that have been called multiculturalism.

I think this common idea is a good one. It is a good idea for a number of reasons. It is a good idea, first, because the old practice of imposing Christian, Anglo-Saxon tradition was rooted in-and to that extent expressesracism and anti-Semitism (and sexism and heterosexism ... but that is another story). But it is a good idea, second, because making the culture of one subculture the official culture of a state privileges the members of that subculture-gives them advantages in public life-in ways that are profoundly antiegalitarian and, thus, antidemocratic.

Yet agreeing to this idea does not tell you much about what you should do in schools and in public culture. It tells you that you mustn't impose certain practices and ideas, but it doesn't tell you what you should do affirmatively. I want to suggest that one affirmative strategy in this area is a bad idea for public education and that there are other strategies that are better. And then, in closing, I want to say something about why living together in a multicultural society is bound to turn out to be difficult. 
Many multiculturalists seems to think that the way to deal with the fact of our many cultures in the public education system is to teach each child the culture of its group. This is the strategy of many Afrocentrists and of some (but by no means all) of those who have favored bilingual education for Hispanics.

This is the strategy I oppose.

To explain my first basis for objection, I need to elicit a paradox in this approach, which we can do by considering the Afrocentric answer to the question: Why should we teach African American children something different from what we teach other children? The Afrocentric answer comes in two parts: the first part says that we should do so because they already come from a different culture; the second part says we should do so because we should teach all people about their own traditions.

It's the first answer that is paradoxical. It is paradoxical because it proposes to solve the problems created by the fact that children have different cultures by emphasizing and entrenching those differences, not by trying to reduce them ${ }^{20}$ I should make it plain that I have no problem with the argument that children's home cultures need to be taken into account in deciding how to teach them: there's no point in talking to kids in languages or dialects they don't understand or punishing them for behavior that they are being taught at home. But to admit that is to admit only that culture may sometimes make a difference to how you should teach, not that it should make a difference to what you should teach. And defending teaching children different histories (Afrocentric history) or different forms of speech or writing (Black English) on the grounds that this is already their culture simply begs the question: if we teach African-American children different histories from other children, then, indeed, it will become true that knowing that history and not knowing any other history will be part of the culture of African Americans. But the fact is that if we don't enforce cultural differences of this kind in the schools, surely they will largely disappear.

The contrast here with the multicultural realities of a country like Ghana could not be more striking. For there substantial differences in language and culture are created outside the state, independently of the media and the schools. There it is really true that schools need to work hard to create a shared culture, here it is increasingly true that schools are central in articulating cultural differences.

And what that means is that the only serious argument for Afrocentricity that survives is the second answer I considered earlier: the claim that we 
must teach each child the culture of "its" group, because that is the right thing to do, because we should.

That idea is much more powerful. It is presumably at the basis of the thought that many nonobservant Jews share with observant Jews (who have other reasons for believing this), namely, that it is good to teach their children Jewish history and customs because they are Jewish children. It is the argument- "we have Plato to our father"- that led to the sense of exclusion that many African Americans felt when the history and culture of the United States was taught to them as the continuation of a white Western tradition, the argument against which so much Afrocentrism is a reaction. I myself am skeptical of all arguments of this form: I think that traditions are worth teaching because they are beautiful and good and true, never because they are ours or yours, mine or thine. After my first Seder, it struck me that this was a tradition worth teaching to everybody, Jew or Gentile; and I have always valued the experience of family community among my Muslim cousins at Ramadan. But this is not the place to pursue this argument. Because all I need to point out here is that even if teaching children "their" history is good, it is not something that it would be practical for American public schools to do. For if carried to its ultimate, this policy would require segregation into cultural groups either within or between public schools, in ways that would be plainly unconstitutional in the United States. And if we did have unsegregated classes teaching Jewish history, and African-American history, and Anglo history, and Hispanic history, and Chinese history in our schools, by what right would we forbid children from going to the "wrong" classes?

Of course there are things that we surely all believe that we should teach all American children: in particular, we should teach them something of the history of the American political system. And here too is another reason why we cannot hope to teach each child only "its" cultural tradition: for understanding the American constitutional system and its history requires us to know about slavery and immigration, about the Civil War and Reconstruction, the Underground Railroad and Ellis Island. If there is a sense in which each of these belongs more to the history of some social groups than others, there is also a clear sense in which they belong to us all.

And it is that idea that motivates the approach to dealing with our multicultural society that I favor, that undergirds my multiculturalism, a multiculturalism whose affinities with an older pluralism will, I hope, be obvious. 
For it seems to me that what is ideal in a multicultural society, whose multicultural character is created outside the state in the sphere of civil society, is that the state should seek in its educational systems to make these multiple subcultures known to each other. A multicultural education, in my view, should be one that leaves you not only knowing and loving what is good in the traditions of your subculture but also understanding and appreciating the traditions of others (and, yes, critically rejecting the worst of all traditions). This approach has its practical problems also: a curriculum filled with the history of Korean Americans and African Americans and Anglo Americans and Jewish Americans and so on risks being a curriculum with a shallow appreciation of all of them. But the principle of selection is clear: we should try to teach about those many world traditions that have come to be important at different stages of American history. This means that we begin with Native American and Protestant Dutch and English and African and Iberian cultures, adding voices to the story as they were added to the nation. Because different elements are important to different degrees in different places today, we can assume that the balance will be and should be differently struck in different places. ${ }^{21}$

I have a final argument against Afrocentricity and suchlike movements. It is that they are dangerous, for reasons that have to do with the final point I want to make, which is about the difficulty of managing multiculturalplural-societies.

I said earlier that no one is likely to be troubled by the variety of subcultures in high culture. Why is this? Because however important our participation in high culture is, it is unlikely to be at the heart of our ethnicity. High culture crosses ethnic boundaries to an extraordinary degree. (The boundaries that it crosses with less ease are those of class.) The result is that subdivisions of high culture are not so likely to become central to the organization of political life. The United States is not threatened by the cultural autonomy of the American Philosophical Association (to which I have the privilege of belonging) or (even) the American Medical Association (to which I have the privilege of not belonging). In this respect the associations of high culture are like many elements of popular culture: the next New York mayoral election is not going to be between followers of the Mets and of the Yankees.

But differences in subcultures - in the anthropologist's sense of cultureare rather different. We pass on our language to the next generation because we care to communicate with them; we pass on religion because we care for 
its vision and endorse its values; we pass on our folkways because we value people with those folkways. Even when these values are not explicitly articulated, they lie at the heart of our self-conceptions and our conceptions of community. Culture in this sense is the home of what we care about most. If other people organize their solidarity around cultures different from ours, this makes them, to that extent, different from us in ways that matter to us deeply. The result, of course, is not just that we have difficulty understanding across cultures - this is an inevitable result of cultural difference, for much of culture consists of language and other shared modes of understanding - but that we end up preferring our own kind: and if we prefer our own kind, it is easy enough to slip into preferring to vote for our own kind, to employ our own kind, and so on. In sum: Culture undergirds loyalties. To the extent that these loyalties matter they will be mobilized in politics, except to the extent that a civic culture can be created that explicitly seeks to exclude them. And that is why my multiculturalism is so necessary: it is the only way to reduce the misunderstandings across subcultures, the only way to build bridges of loyalty across the ethnicities that have so often divided us. Multiculturalism of this sort-pluralism, to use an older word-is the only way of making sure we care enough about people across ethnic divides to keep those ethnic divides from destroying us.

The task is not to replace one ethnocentrism with many, not to reject old ideals of truth and impartiality as intrinsically biased. Rather it is to recognize that those ideals have yet to be fully lived up to in our scholarship, that the bias has derived not from scholars who took Western standards (which often turn out to be everybody's standards) of truth for granted, but that they didn't take them seriously enough.

The old way of dealing with the problem of many cultures was to make us e pluribus unum. Out of many cultures, to mold one. Anyone who appreciates the vibrancy of American popular culture and high culture, the splendid variety of our literatures and musics and cuisines, is likely to balk at such a project. And anyone who has looked at our history and seen how often the one into which we were to be made was white and Anglo-Saxon and Protestant will be skeptical that the one into which we are to be made could be anything other than the cover for the domination of one of our sectional cultures. These are, in my view, legitimate skepticisms. And the only alternative, so far as I can see, that doesn't threaten perpetual schism is the hard work of a multiculturalism that accepts America's diversity while teaching each of us the ways and the worth of others. 


\section{Notes}

Pages 38-41 of this chapter are based on chapter 9 of Kwame Appiah, In My Father's House: Africa in the Philosophy of Culture (New York: Oxford University Press, 1992). Some passages cited in the text are from my own unpublished transcription of an interview edited and published as "Interview with Anthony Appiah, D. A. N. Jones, and John Ryle," Times Literary Supplement, 26 February 1982.

1. My father would never have forgiven the solecism of trying to explain a proverb!

2. About half of those arrested in the Los Angeles riots were Latino; a little over a third were black. This is unlikely to be a "fair" representation of rates of participation in the unrest, since there is some evidence that the police were more likely to arrest Latinos. But the point is that these figures do show what many people will have seen on their televisions, namely, that the riots were not monoracial.

3. See, for example, Robert Harms, Times Literary Supplement, 29 November 1985, 1343.

4. See Kwame Appiah, In My Fathers House: Africa in the Philosophy of Culture (New York: Oxford University Press, 1992), chs. 1, 2, and 9.

5. Okomfo Anokye is the name of the priest who helped the first of the Asante kings, Osei Tutu, form the nation from the various Akan kingdoms that it united. He is said to have brought the Golden Stool, symbol of Asante kingship, down from heaven.

6. Tzvetan Todorov, "'Race,' Writing and Culture" in "Race," Writing and Difference, ed. Henry Louis Gates, Jr. (Chicago: University of Chicago Press, 1986), 370-80. You don't have to believe in witchcraft, after all, to believe that women were persecuted as witches in colonial Massachusetts.

7. Gayatri Spivak recognizes these problems when she speaks of "strategic essentialisms." See Spivak, In Other Worlds: Essays in Cultural Politics (New York: Routledge, 1988), 205.

8. See, for example, K. Anthony Appiah, "The Uncompleted Argument: Du Bois and the Illusion of Race," in Gates, 21-37; and K. Anthony Appiah, "Alexander Crummell and the Invention of Africa," Massachusetts Review 31 (Autumn 1990): 385-406.

9. The violence between Senegalese and Mauritanians in spring 1989 can be understood only when we recall that the legal abolition of racial slavery of "Negroes" owned by "Moorish" masters occurred in the early 1980 s.

10. See Wole Soyinka, Myth, Literature and the African World (New York: Cambridge University Press, 1976).

11. Kwasi Wiredu, Philosophy and an African Culture (New York: Cambridge University Press, 1980), 38.

12. "Interview with Anthony Appiah, D. A. N. Jones, and John Ryle," Times Literary Supplement, 26 February 1982.

13. David Laitin, Hegemony and Culture: Politics and Religious Change among the Yoruba (Chicago: Chicago University Press, 1986), 7-8. 


\section{Laitin, 8.}

15. This passage continues: "Increasingly also Lingala and Swahili came to divide functions between them. Lingala served the military and much of the administration in the capital of the lower Congo; Swahili became the language of the workers in the mines of Katanga. This created cultural connotations which began to emerge very early and which remained prevalent in Mobutu's Zaire. From the point of view of Katanga/Shaba, Lingala has been the undignified jargon of unproductive soldiers, government clerks, entertainers, and, recently, of a power clique, all of them designated as batoka chini, people from down-river, i.e. from Kinshasa. Swahili as spoken in Katanga was a symbol of regionalism, even for those colonials who spoke it badly." Johannes Fabian, Language and Colonial Power (New York: Cambridge University Press, 1986), 42-43. The dominance of Swahili in certain areas is already itself a colonial product (Fabian, 6).

16. Similarly Shona and Ndebele identities in modern Zimbabwe became associated with political parties at independence, even though Shona-speaking peoples had spent much of the late precolonial period in military confrontations with each other.

17. Laitin, 8. I need hardly add that religious identities are equally salient and equally mythological in Lebanon or in Ireland.

18. That "race" operates this way has been clear to many other African Americans: so, for example, it shows up in a fictional context as a central theme of George Schuyler's Black No More (New York: Macaulay, 1931); see, for example, p. 59. Du Bois (as usual) provides in Black Reconstruction: An Essay Toward a History of the Part which Black People Played in America 1860-1880 (New York: Russell and Russell, 1935) a body of evidence that remains relevant. As Cedric Robinson writes: "Once the industrial class emerged as dominant in the nation, it possessed not only its own basis of power and the social relations historically related to that power, but it also had available to it the instruments of repression created by the now subordinate Southern ruling class. In its struggle with labour, it could activate racism to divide the labour movement into antagonistic forces. Moreover, the permutations of the instrument appeared endless: Black against white; Anglo-Saxon against southern and eastern European; domestic against immigrant; proletariat against share-cropper; white American against Asian, Black, Latin American, etc." Cedric Robinson, Black Marxism: The Making of the Black Radical Tradition (London: Zed Press, 1983), 286.

19. See Robinson, 313.

20. I think of this as the "WASPS have Christmas, Jews have Hanukkah, so Blacks should have Kwanzaa" approach.

21. All of this presupposes a general improvement, I should add, in the quality of American elementary and secondary education. 


\title{
Chapter 3 \\ Meanings for Multiculturalism
}

\author{
C. Vann Woodward
}

Before we get very far in the discussion of multiculturalism in the university, it might be well to agree, if possible, on what it is we are talking about and on how we define and use the word "culture." We need not pause over the prefix "multi" or the suffix "ism," but the key word "culture" requires close attention. Starting from the Latin root word cultus, to till, the word in English has taken on usages not only in agriculture but also in education, religion, and art. Historians once spoke of "high culture." The usage most commonly involved in our present discussion, however, is the one developed by anthropologists. They are not entirely consistent in their usage of the word, but "culture" for them usually means the sum total of behavior patterns, arts, values, beliefs, institutions, and other products of work and thought characteristic of a people and socially transmitted.

If we accept as a working definition the latter usage of "culture," we clarify the confusion by narrowing the definition in some degree. For one thing we remove some groups of the academic community mistakenly described as "cultural" from the cultural category. For example, every culture influences the restraints, discriminations, and status imposed on its female members, but these impositions are part of the culture in which women live, and do not constitute a separate culture for women. The same is true of homosexuals and the members of classes that divide any culture. This is in no way intended to dismiss or diminish the injustices they suffer, but these are results of conflicts within a culture, not between separate cultures. With regard to racial, ethnic, and national minorities, categories less clearly defined, it is not so easy to deny separate cultural identity. For each of them that much of separate identity has been claimed at one time or another, and their claims should be fairly assessed.

Americans of African descent have been especially insistent in claims of a separate culture based upon race; and these claims in the academy have been, if anything, increasing over the last decade. Proponents of the black 
culture movement often turn to the mother continent for "roots," for bonds of unity, for cultural origins, and for the heritage of an ancient past. In so doing they are attempting to identify race with culture. They are also attributing to African history and Africans characteristics that have to be critically examined before we can accept them as foundations for African-American unity and cultural identity.

Of the three extant human types completely indigenous to Africa, only one is visibly represented among African Americans. That is the tallest, darkest, most dominant, and most numerous type, the type with which the history of human development south of the Sahara has been almost exclusively concerned. They were the Africans known elsewhere as "Negroes," a term not used on the continent itself, nor by present-day scholars save in quotation marks. For one thing the term has acquired derogatory connotations, but scholars reject it primarily because it is so unsatisfactory when used to describe people of such wide differences in culture as well as in physical appearance. Scholars list 60 , some over 160, different ethnic groups, from the Asanti to the Zulu. These people south of the Sahara have developed at least a thousand distinct languages, including fifty major ones (each spoken by a million or more people), and a multitude of dialects in addition. That is far more languages than can be found in any other continent, making Africa the one of greatest linguistic complexity. African languages have little relevance to national boundaries, and most of the postcolonial nations retain a major European language as the official tongue, even though it is not spoken by many of their citizens.

Turning to other cultural diversities, those of religion are less marked than those of language, with Christian and Muslim forms predominating. Christianity of the Coptic order gained footing in Egypt in the first century and Ethiopia in the fourth, well in advance of West European foundings. But the large-scale Christian gains in Africa did not come until the nineteenth century, when Christian denominations made great strides. Recent estimates are some sixty-four million Roman Catholics, sixty million Protestants, and thirty-four million Independent Protestants and Coptics. The pattern of these religions is similar to that in Europe and America. The largest number of Christians are in South Africa, Zaire, Nigeria, and Uganda. Islam entered Egypt in the year 640 and reached the Atlantic by the end of the century, but did not gain hold south of the Sahara except along the eastern coast until the eleventh century, and, like Christianity, waited until the nineteenth century for its greatest expansion in Africa. Muslims' numbers, how- 
ever, never rivaled those of the Christians. In addition to the major organized religions are numerous preliterate traditional religions, which coexist with both Christianity and Islam, often within the same individual, and frequently dominate them.

In addition to language and religion, the creative arts are important components and expressions of a culture. And in sub-Saharan Africa all the familiar forms are found--sculpture, painting, architecture, music, dance, drama and poetry, textiles and other fabrics, along with costume and jewelry. Knowledge of sub-Saharan arts is still fragmentary, but the earliest known sculpture goes back to 500 в.c. Old and modern art of the continent, rich and fascinating as it is, comes in such a bewildering variety of styles, however, that it is little help to call them "African." While there are a few themes in common, each style was developed in its own particular historical, ecological, and social circumstances. Christianity did not serve to universalize art as it did in Europe, and Islam frowned upon the use of images. Traditional religions, on the other hand, favored artistic particularism, while language and ethnic barriers did not promote exchange of influence and ideas among the artists. The American minorities who look to Africa for the foundation of the cultural unity to which they aspire will look in vain. Africa itself is multicultural—extravagantly, even disastrously, so. Yet romantic black Americans imagine it to be a single culture.

If color and race have not served to unify African cultures, neither has color or ethnicity served to unify Africans. That was true of precolonial Africa, and it has remained true throughout the European intrusions and aggressions of modern history. The Atlantic slave trade failed to bring about unified black resistance, in part because Africans were themselves slaveholders of a milder sort, and in part because some African chiefdoms accepted partnerships with Europeans and Americans in the trade, providing the enslaved and profiting thereby. Prominent among such partners, incidentally, were the Swahili, whose language black American students in the 1960s, then wearing their dashikis, eagerly studied — but not for very long. Unilingual students with multicultural enthusiasms are quite common.

European imperial powers, in colonial control and exploitation of African peoples after the 1880s, though differing in particulars from one colony to another, all used the ancient strategy of divide-and-rule. But they did not have to do all the dividing themselves, since their preliterate and preindustrial subjects were already divided in numerous ways. Politically they were divided into a few kingdoms, a large number of small chiefdoms, and many. 
who lived without any central authority at all. None of them were strong enough to prevent colonization. Their experience as colonial subjects under seven separate European powers differed greatly. The worst horrors were those suffered in the Congo Free State under Belgian rule, but the lives of many Africans were little affected by colonialism.

After the end of colonial rule, beginning in the 1950s, the newly independent nation-states gained some measure of independence but little unity, either between nations or within their rather arbitrarily drawn borders. Partly to blame was continuation or renewal of foreign economic control and interventions by the two major parties to the Cold War. In addition to foreign meddling and the heritage of colonial bureaucracy, the Africans were cursed with wretched poverty. Of its 160 members, the United Nations reports recently that 32 of the 40 most impoverished are in Africa.

The prevailing political system following "liberation" of the African colonies was heavily authoritarian-dictatorship in one form or another. In its annual classification of nations in 1987 Freedom House rated only three of the fifty-two African nations as "free," fifteen as partly free, and thirtyfour as not free. The next two years saw a turn for the better and promise of more democracy, with eight states rated free, twenty-three as partly free, and a decline of highly authoritarian states to twenty-one. To some this seemed a "second liberation," but to others these years spelled retrogression, as in Algeria, Angola, Liberia, Nigeria, Zaire, and others. By 1996, nothing much had changed: nine free, twenty partly free, and twenty-four not free. Dictators and their regimes were as harshly brutal and totally corrupt as ever.

Ethnic differences, illiteracy, and droughts add other miseries to the wretchedness of poverty and dictatorship. But with those misfortunes came civil wars and anarchy that disgraced many African states during the last three decades of independence. In fifteen nations south of the Sahara, civil wars raged in 1993 along ethnic lines. None of these conflicts has yet been resolved. One has only to think of the endless mayhem following the dissolution of the Ethiopian empire, or the horrors in Uganda, the Sudan, Tanzania, Mozambique, Nigeria, Angola, Somalia, Rwanda, Burundi, and Zaire, to mention only a few examples. Even in the midst of struggles to bring to terms or end lingering white minority regimes and apartheid in Zimbabwe and South Africa, blacks could not put a stop to the slaughter of blacks by blacks. And in famine- and drought-ridden Somalia, warring factions could not suspend the civil strife resulting in 300,000 deaths long enough to permit the Red Cross to bring temporary relief to their starving millions. 
If by any chance my sad account of events in Africa should bring to mind developments not entirely dissimilar taking place to the north and northeast of the "dark continent," then I must admit that this coincidence had also occurred to me. In fact, I have not been wholly innocent of deliberate intention of provoking this analogy. I believe it could prove useful in our reflections upon culture wars and multiculturalism. The New York Times goes so far as to say that "today's true dark continent begins in the Balkans and extends eastward."

It is naturally the similarities and correspondences that come to mind first, for they are the more striking and unavoidable. To think of the pathetic pictures from Somalia is to think of those from Bosnia appearing in the same edition of our newspapers and news broadcasts. Dissimilarities between the ferocity and destructiveness of cultural and ethnic wars on the two continents are in large part due to disparities in the firepower and effectiveness of weapons available. With the more modern and superior armaments at their disposal, warriors of cultural hatred to the north have far outstripped those of underdeveloped Africa. No horror of Africa equals that of Europe's Holocaust. Hate conflict has torn the Near East and Middle East to shreds, turned Lebanon into a no-man's-land, and left Beirut in ruins. The tragedy of culture conflict and its ancient hatreds and feuds has subjected Croatia and Bosnia-Herzegovina to the ravages of what is called "ethnic cleansing" and turned many inhabited cities and architectural treasures into rubble. From the Balkans in the south to the Baltic in the north of Europe, cultural and ethnic differences disturb the peace of the world in one degree or another, and they are more in evidence than ever to the east and west of that region. It would seem, indeed, that multiculturalism and its consequences have become an obsessive preoccupation, a spreading fever of tribalism, in large parts of the world.

One of the several ironies in the recent spread of this fever is the part played by what was otherwise regarded as a boon to the cause of world peace. That is the collapse of communist power over vast areas and the substitution of democracy or at least attempts at democratic self-rule. But this also meant an end to the iron discipline that had held united the multicultured republics of Eastern Europe that were cobbled together after the First and Second World Wars and left under control of Russia. Some of these, for example, Czechoslovakia, began to come apart, and others to suffer internal strife of one ethnic or cultural group against another. The dissolution of Tito's variation of the Russian dictatorship in Yugoslavia was also in part the 
result of the collapse of that regime. More ominous was the dissolution of the Soviet Union itself and the consequent emergence of new nation-states and revival of suppressed nations.

But the now defunct Soviet Union embraced more cultures than it did nations. It has been compared with a state that united a Norway and a Pakistan-and one might throw in an Afghanistan. But it was more complex than that, for in addition to glaring disparities in economic development, several of these nations were divided culturally against themselves, divided by language, by religion, by history, and some by age-old hatreds. The Soviet state had attempted to create a melting pot, based on Soviet Russian culture, for these multicultural multitudes. The policy failed. The pot did not melt. When the force imposing the policy was removed, the unrest of repressed cultural minorities and majority hatreds of them broke into conflict and violence in many areas, earliest in Kazakhstan and Yakutiva, most violently against minorities in the Central Asian republics. Pogroms in Uzbekistan against Meshketian Turks were so ugly that they forced an evacuation from the Uzbek republic. Christian Armenians and Muslim Turks continued their century-long strife. In the Caucasus, Russia brutalized Chechnya; Georgia abused the human rights of its minorities: Armenians, Russians, Azerbaijani, Greeks, Jews, Ukrainians, and Kurds.

And so it goes, with cultural, ethnic, and religious conflict producing thousands of casualties and hundreds of thousands of exiles and refugees. Boris Yeltsin fears ending up in a neo-Balkan abyss. But the presence of 25 million Russian inhabitants in the new non-Russian states and their appeal for Russian military intervention to protect their rights, supported at home by Russian nationalists, threatens to undermine the Yeltsin policy. Gloomy predictions of the new order turning out to be another Weimar prelude to new varieties of fascism are often heard. It is too early to say what all this portends for the future of the fifteen new states of the former Soviet Union or its former satellite countries to the west. But it is not too early to conclude that multiculturalism is not the ideal foundation for national peace, unity, and stability, and that such of these achievements as now exist are haunted by terrible fragility.

European nations to the west of the old Iron Curtain and Berlin Wall are not without their own varieties of what the Germans call the Kulturkampf. The dividing line, or zone, between Eastern and Western European multicultures runs north and south all the way across the continent, a wandering line defined by religion and history. To the east is the Europe of Orthodox 
or Greek Christianity and Islam; to the west, the Europe of Roman or Latin Catholicism and Protestantism. On the one side are nations formed by the collapse of the Ottoman and Hapsburg empires, while on the other side are those shaped by Renaissance, Reformation, Enlightenment, and Revolution. The line roughly sets off Poland from Ukraine; claims the Baltic republics, the Czechs, and most Hungarians for the West; splits Romania; and divides Yugoslavia. These ancient cleavages of the spirit and culture can surface with startling force in modern times. "We have been waiting for this moment for eight centuries," said the defense minister of independent Croatia in 1991.

The manifestations of multiculturalism in Western Europe have in recent centuries proved somewhat less bloody and more manageable than those of the East. But the West was populated by migrations from the East, and few nations can claim ethnic purity. Even the English are plagued by explosions of Celts in Ireland, the French by Celts of Breton, the Spanish by Basque Celts, and Portugal by Celts of her own. In addition to the western fringe of Celts, these nations have other, if more dormant, minorities. England before the Roman conquest had the Danish invaders and afterward the Normans, and is now by way of being colonized by those it once colonized in Asia and the West Indies. France copes with Vikings, Gauls, Catalans, and Provençals of older times in addition to modern Polish and Russian Jewish migrants and recent immigrants from her former colonies in Asia and Africa. Spain contains older immigrants, Iberian, Visigoth, Vandal, Catalan, Castilian, Greek, and Arab. And surely the two nations populating Belgium, the Walloon and the Flemish, must not be overlooked.

It is of some comfort to find in Western Europe movements now under way to counter the divisive effects of these cultural and national enmities, not only in the West but in other parts of the world. In the West we have the hesitant and stumbling struggles for unity expressed by the European Community. And beyond that exists a growing bond between democracies or would-be democracies of West and East that are seeking ways to head off ethnic conflicts and force negotiation. These efforts have involved the United Nations, the European Community, and the Conference on Security and Coöperation in Europe. Their attempts have so far failed in Yugoslavia and in Soviet successor states and are likely to meet with other failures for a long time to come, but they do continue their efforts.

And now what has all this to do with our transatlantic New World? Well, before we turn to the United States, we might spare a moment for a glance at our neighbor - or perhaps I should say neighbors - to the north. For the 
Canadian territory, rather like Belgium with its Walloons and Flemings, is inhabited by two nationalities. In addition to the more recent influx of immigrants from all over, Canada has for centuries consisted of two populations, the British and the French. And we to the south have watched with anxiety while they periodically threaten to tear themselves apart.

The population of the United States is in the vast diversity of its origins perhaps the most multicultural in the world. That made assimilation a matter of necessity, a matter of national survival, and helps explain the extremes of American nationalism as a means to that end. Immigrants poured across the Atlantic from all countries and cultures of Europe in tidal waves and human hordes. In the single century from 1815 to 1914 over 35 million came across, largely as individuals, and in the twenty-five years of greatest intensity in that century 17 million crossed over. That overshadows all other population movements in human history up to that time, dwarfing the barbarian invasions of the late Roman Empire into numerical insignificance.

By 1890 one in every four Philadelphians was foreign-born, and in Boston and Chicago one out of three. Greater New York City, with four out of five foreign-born or of foreign parentage, had half as many Italians as Naples and two and a half times as many Irish as Dublin. To those new immigrants were to be added increasing numbers coming in on the other side of the continent from Asiatic countries and cultures. All Americans are descended from immigrants of the last four centuries except the native Indians-with enormous tribal diversities of their own-whose immigrant ancestors are a bit more remote.

The great majority of the immigrants came to America to better their lot or to escape worse abroad. Few of them came to preserve, perpetuate, or spread their Old World culture in the New World. Rather their urge was to shed their foreign ways, looks, and accents and take on the new ways, looks, and speech as quickly as possible - to Americanize, to assimilate. Prominent Europeans of the last century and more-Alexis de Tocqueville, James Bryce, Gunnar Myrdal-marveled at and admired the success of the American policy of assimilation, what Lord Bryce called "the amazing solvent power which American institutions, habits, and ideas exercise upon newcomers of all races."

But what about the oldest and largest American minority of all-in terms of the percentage of the race whose ancestors arrived in the seventeenth and eighteenth centuries? I mean the African Americans, whom I have so far rarely mentioned. Neither did J. Hector St. John de Crèvecoeur in 1782 when he defined the American as "either an European or the descen- 
dant of an European"- thus silently defining blacks and others of non-European descent out of American identity. In so doing he had the support of the majority of white Americans and their government. For it was the glaring failure and disgrace of the American promise of assimilation and equality to all comers that it was denied to African Americans and continued to be withheld long after their liberation from slavery. Yet they, among the oldest of the immigrants, as much as the latest, continued to demand and struggle for assimilation, integration, and equality in the American system.

It is true that an occasional back-to-Africa movement attracted a few followers; and with the help of whites who wanted to rid the country of free blacks, Liberia was founded in 1847 to receive them. But the outstanding leaders of African Americans, from David Walker in 1829 to Martin Luther King, Jr., in the 1960s, have resisted that romantic appeal of Africa and called instead for assimilation and integration and equality in American society. When King declared unequivocally, "The Negro is American. We know nothing of Africa," he was echoing W. E. B. DuBois, who in his early career had said his black associates "felt themselves Americans, not Africans," and who noted among NAACP members, "a fierce repugnance toward anything African." I am aware, of course, that DuBois later underwent a change of view on cultural separatism.

DuBois, in fact, later pointed the way for other American minoritieswhether black, brown, yellow, red, or white-that in recent years have suddenly renounced long-cherished goals of integration and assimilation and joined movements of cultural separatism. Each of these has its own separatist slogans, myths, and programs of ethnicity, and they are often at odds with one another. For example Hispanic Americans reject "Black English" but promote bilingualism, which African Americans reject. Both of them are potential sources of cultural fragmentation and separatism, though mutually antagonistic. What these various culturally separatist groups have in common is the cult of victimization, inflammable sensitivity, and a passion for "roots" and recovery of an ancestral culture, however remote. That does not bring them together, but instead encourages self-segregation. Whereas Chief Justice Warren held in the Brown school-segregation decision of 1954 that segregation "generates a feeling of inferiority," the multiculturalists with political ends now contend that it is integration that generates such feelings and that segregation is the cure instead of the cause.

It would at first seem ironic that the oldest of the American minorities should be the one to take the lead in these neosegregation movements. Yet 
it is the one that has suffered most from exclusion, injustice, discrimination, and denial of assimilation. And before we weigh criticisms of American multicultural separatism, we should acknowledge certain positive contributions. Most important has been to force long overdue recognition of the contributions that racial minorities and women have made to national achievement and American civilization. This in turn has resulted in admission of the long unchallenged dominance by white male Anglo-Saxons and their casual habit of claiming credit for everything and collecting most of the honors and rewards.

But the cost of these gains threatens to be excessive. One of the threats is to the long-standing and peculiarly American tradition that has been the envy of all countries torn by multicultural conflict-the remarkable success, despite failures noted, it has enjoyed with its policy of assimilation and integration of all cultures. I agree with Arthur M. Schlesinger, Jr., who in The Disuniting of America says we are facing "a struggle to redefine the national identity" and an effort to change it from "a transformative nation with an identity all its own" to a nation that preserves or revives old identities, that thinks and acts in groups, in "a quarrelsome sputter of enclaves, ghettos and tribes," one that cherishes pluribus over unum and abandons the national ideal of $e$ pluribus unum.

Few adherents of these culturally separatist movements joined them with such direful intentions in mind. But extremists often influence and sometimes dominate the members and are permitted to speak for them. Extremists among the Afrocentrists, for example, denounce or trivialize Western or European culture while at the same time claiming that Africa was schoolmaster to Greece and Rome and "the mother of Western civilization." Another divides humankind into the cold, materialistic "ice people" of the North and the warm, humanist "sun people" of the South, the former bringing death and destruction, the latter joy and happiness. Still another, a black psychiatrist, attributes white racial inferiority to lack of the skin pigmentation melanin. A black psychologist contends that the mind of the black student works in distinctive ways in learning and thinking, thus accounting for their difficulties under the present educational system and the need for racially separate classes to teach "Black English" and for black professors for black students. The black Nation of Islam has published a massive volume of anti-Semitism, hate literature blaming Jews for leading responsibility in the Atlantic slave trade. And from another quarter we hear black supremacy proclaimed in terms as bigoted as those once used by white supremacists. 
Shall we then discourage or exclude the study of multiculturalism from the university curriculum? By no means! Not when an understanding of the long and bloody history of multicultural societies and their conflicts is so urgently relevant to events of our own time-at home as well as abroad. I fondly believe that had the last two or three generations of American college students been exposed to the sort of history I outlined in the first half of my paper, particularly the multicultural history of sub-Saharan Africa, they might have been spared many of their current misadventures in cultural separatism and romanticism. No, what the academy needs is more rather than less attention and curriculum time devoted to the history and consequences of multiculturalism-using the term as I have used it here.

Which reminds me of the title I chose for this essay: "Meanings for Multiculturalism." The term has quite a different meaning and connotation in the current language of cultural separatists in American universities. There it is commonly used to mean the courses taught, the faculty appointed, the living and dining arrangements provided, and the codes of conduct passed in order to promote the separatism and political ends of various organized groups, whether racial, sexual, national, or whatever. This strikes me as a misuse of the university, a political use, and a misconception of the purpose, the mission, and the very idea of the university. Unlike the study of multicultural history I advocated, the political multiculturalism of the separatist cults is, I think, harmful.

I do not mean to include as harmful scholarly courses in racial, sexual, or national history and literature. Had black students been exposed to courses of this sort, for example, they would have been aware of what such distinguished fellow citizens as Frederick Douglass, W. E. B. DuBois, James Baldwin, Richard Wright, Horace Mann Bond, Ralph Bunche, and John Hope Franklin have had to say about looking back three hundred years to Africa for cultural roots, rituals, and colorful costumes to wear in public. Propaganda-free courses of high quality and standards on the history and literature of minorities are still offered, and more are needed to do justice to the rich contributions minorities have made that have been neglected or ignored in our curriculum for the humanities.

But these are not the objectives that multicultural separatists have primarily in mind. The history for their new curriculum is inventive and exculpatory, purposive history to shape group identity, unity, and pride of self-esteem. Their mission is not to enrich or add to the existing culture and university curriculum, but rather to replace them, often by denigrating and 
demeaning the prevailing system and its originators. The Afrocentric teachings I offered as examples a bit earlier- "ice people" versus "sun people," skin pigmentation as the secret of racial superiority, racial differences in the learning process, black teachers and separate departments for black students-may have struck some as extremist. And so they are; but the perpetrators of all these doctrines cited, with the exception of the Nation of Islam, have tenure in faculties of reputable colleges and universities.

Preferences, wishes, and demands of separatist groups and organizations have met with little resistance from some university administrations and with eager compliance from a few in faculty appointments and promotions and student admissions. University presidents have on some occasions applauded and extravagantly financed segregated student unions, dormitories, and dining halls and approved or condoned segregated clubs, fraternities, and sororities. There exists at least one instance of a separate yearbook for the senior class. Athletic teams have universally resisted segregation and adhered rather strictly to standards of merit and achievement. Alumni notoriously prefer victory to virtue.

The elaborate pains taken to accommodate segregation have been explained in part as a means of avoiding tensions, insults, and conflicts. As things turned out, however, the more segregation flourished and other precautions were taken, the more instances of harassment, slurs, and insults occurred. The University of Michigan desperately developed scores of programs for "consciousness raising" and "sensitivity training" for whites and covered the campus with posters condemning racial and sexual harassments. When black students denounced these efforts as racist, the university finally resorted to adopting an elaborate code of racial and sexual etiquette and penalties for speech that violated it. This example of speech censorship was followed by numerous universities all over the country until the American Civil Liberties Union filed a suit and U.S. District Judge Avern Cohen declared the Michigan code unconstitutional. Judge Cohen pointed out that "statutes punishing speech or conduct solely on the grounds they are unseemly or offensive are unconstitutionally overbroad."

It is good to hear some voices among champions of black studies calling for moderation and compromise, even if not always consistently. One such voice, for example, is that of Professor Henry Louis Gates, Jr., of Harvard University. It is reassuring to read his forthright denunciation of the violent antiSemitism of the Nation of Islam, his admission that some of the hundreds of black studies programs are intellectually "bogus" for inventing an African 
past that never was, and his acknowledgment that irrationality, racism, and victimization are not all on one side. On the other hand he finds occasion to write that "now we must at last don the empowering mask of blackness and talk that talk, the language of black difference." Only thus, it seems, can we "know and test the dark secrets of a black discursive universe that awaits its disclosure through the black arts of interpretation." Dark secrets and black arts at Harvard?

The real clue to the power of multiculturalism in universities is not political correctness but moral correctness. In almost any group of separatists we are dealing with here we are confronted with moral issues, some older and deeper than others to be sure, but all involving injustice, neglect, and abuse, including inhuman brutality, a record at odds with the most cherished principles of American democracy. It would be morally obtuse for us to remain indifferent to these grievances and for a society to do nothing to correct them. The question is whether the university is the place to do this. Given the amount of white guilt endemic to current-day university circles, it is not surprising to find many eager to assume the entire responsibility.

On this difficult question I find wisdom in the views held by my colleague Professor Jaroslav Pelikan of Yale. In his book The Idea of the University: A Reexamination, he writes that "the university urgently needs to find new ways of protecting the freedom of inquiry without allowing itself to become the tool of the polarities of nation, race, class, and gender that will continue to shape the ideological climate both outside and inside the academy." He also observes that the university "can run the danger of debasing the educational currency in the very process of redistributing it."

It remains to account for the degree to which university administrations and faculties have yielded to the demands of extremists among the cultural separatists. First a word of sympathy for hard-pressed administrators, whom faculties often give a hard time. No doubt some have proved weak and compliant. But what is one to do when all the complaints and demands come from one side, and the faculty eggs them on? As for the faculty, their alignments are often attributed to radicalism: "tenured radicals," they are called.

I think radicalism in faculties has been much exaggerated. I would hesitate to call all of them tenured conformists, but "conformity" better describes their characteristic response than "radicalism." Radicalism made conformity more difficult for the majority of faculty members, who were liberals or conservatives. The genuine Marxist program calls for class conflict and frowns upon conflict between cultures and races. With the decline 
of ideological radicalism and Marxism everywhere, including universities, moral correctness appeared as a welcome substitute for political correctness, and was surely more comfortable for conformists. Many faculty members, of course, support the multiculturalist movements out of sincere if misguided conviction rather than conformity. That does not make them radicals, however, any more than it does the pure conformists. Nor, I might add, does it turn their critics and opponents into conservatives. 


\title{
Chapter 4 \\ Boutique Multiculturalism
}

\author{
Stanley Fish
}

\section{Multiculturalism Does Not Exist}

Multiculturalism comes in at least two versions, boutique multiculturalism and strong multiculturalism. Boutique multiculturalism is the multiculturalism of ethnic restaurants, weekend festivals, and high-profile flirtations with the "other" in the manner satirized by Tom Wolfe under the rubric of "radical chic."

Boutique multiculturalism is characterized by its superficial or cosmetic relationship to the objects of its affection. Boutique multiculturalists admire or appreciate or enjoy or sympathize with or (at the very most) "recognize the legitimacy of" the traditions of cultures other than their own; but boutique multiculturalists will always stop short of approving other cultures at a point where some value at those cultures' center generates an act that offends against the canons of civilized decency, as they have been either declared or assumed. The death sentence under which Salman Rushdie now lives is an obvious and perspicuous example, although it is an example so extreme that it might be better to begin with a few that are less dramatic. A boutique multiculturalist may find something of value in rap music and patronize (pun intended) soul-food restaurants, but he will be uneasy about affirmative action and downright hostile to an Afrocentrist curriculum. A boutique multiculturalist may enjoy watching Native American religious ceremonies and insist that they be freely allowed to occur, but he will balk if those ceremonies include animal sacrifice or the use of a controlled substance. ${ }^{2} \mathrm{~A}$ boutique multiculturalist may acknowledge the diversity of opinions about abortion, but he is likely to find something illegitimate in the actions of abortion opponents who block the entrance to clinics and subject the women who approach them to verbal assaults. A boutique multiculturalist may honor the tenets of religions other than his own, but he will draw the line when the adherents of a religion engage in the practice of polygamy. 
In each of these cases (and in the many analogous cases that could be instanced) the boutique multiculturalist resists the force of the appreciated culture at precisely the point at which it matters most to its strongly committed members: the point at which the African American tries to make the content of his culture the content of his children's education, the point at which a Native American wants to practice his religion as its ancient rituals direct him to, the point at which antiabortionists directly confront the evil that they believe is destroying the moral fiber of the country, the point at which Mormons seek to be faithful to the word and practices of their prophets and elders.

Another way to put this is to say that a boutique multiculturalist does not and cannot take seriously the core values of the cultures he tolerates. The reason he cannot is that he does not see those values as truly "core" but as overlays on a substratum of essential humanity. That is the true core, and the differences that mark us externally-differences in language, clothing, religious practices, race, gender, class, and so on - are for the boutique multiculturalist no more than what Milton calls in his Areopagitica"moderat varieties and brotherly dissimilitudes that are not vastly disproportionale." ${ }^{3} \mathrm{We}$ may dress differently, speak differently, woo differently, worship or not worship differently, but underneath (or so the argument goes) there is something we all share (or that shares us) and that something constitutes the core of our identities. Those who follow the practices of their local culture to the point of failing to respect the practices of other cultures - by calling for the death of an author whose writings denigrate a religion or by seeking to suppress pornography because it is offensive to a gender-have simply mistaken who they are by identifying with what is finally only an accidental aspect of their beings.

The essential boutique multiculturalist point is articulated concisely by Steven C. Rockefeller: "Our universal identity as human beings is our primary identity and is more fundamental than any particular identity, whether it be a matter of citizenship, gender, race, or ethnic origin."' Taking pleasure in one's "particular identity" is perfectly all right so long as when the pinch comes, and a question of basic allegiance arises, it is one's universal identity that is affirmed, for as "important as respect for diversity is in multicultural democratic societies, ethnic identity is not the foundation of recognition of equal value and the related idea of equal rights." ${ }^{\prime}$ That is to say, we have rights not as men or women or Jews or Christians or blacks or Asians, but as human beings, and what makes a human being a human being is not the 
particular choices he or she makes, but the capacity for choice itself; and it is this capacity rather than any of its actualizations that must be protected.

It follows then that while any particular choice can be pursued at the individual's pleasure, it cannot be pursued to the point at which it interferes with or prescribes or proscribes the choices of other individuals. (This is of course a reformulation of J. S. Mill's "harm principle" in On Liberty.) One may practice one's religion, even if it is devil worship, in any manner one likes; but one may not practice one's religion to the extent of seeking to prevent others from practicing theirs, for example, by suppressing their sacred texts or jailing their ministers. Women may rightly insist that they receive equal pay for equal work, but they cannot rightfully insist that they be given extra compensation or preferential treatment just because they are women. One may choose either to read or to disdain pornography; but one who believes in pornography's liberatory effects cannot compel others to read it, and one who believes that pornography corrupts cannot forbid others to publish it.

Of course it is just those two actions (or some versions of them) that pro- and antipornography forces will most want to take, since they flow logically from the beliefs of the respective parties and will be seen by those parties as positive moral requirements. This is what I meant earlier when I pointed out that the boutique multiculturalist will withhold approval of a particular culture's practices at the point at which they matter most to its strongly committed members: a deeply religious person is precisely that, deeply religious; and the survival and propagation of his faith is not for him an incidental (and bracketable) matter, but an essential matter, and essential too in his view for those who have fallen under the sway of false faiths. To tell such a person that while his convictions may be held he must stop short of fully implementing them is to tell him that his vision of the good is either something he must keep to himself or something he must offer with a diffidence that might characterize his offer of canapés at a cocktail party. ${ }^{6}$ Rockefeller might say that "respect for the individual is understood to involve not only respect for ... universal human potential ... but also respect for ... the different cultural forms in and through which individuals actualize their humanity," but it is clear from his commentary that the latter respect will be superficial precisely in the measure that the cultural forms that are its object have themselves been judged to be superficial, that is, not intrinsic to universal identity.?

The politics generated by views like Rockefeller's has been called by Charles Taylor "a politics of equal dignity." The politics of equal dignity, Taylor 
explains, ascribes to everyone "an identical basket of rights and immunities," identical because it is limited to that aspect of everyone that is assumed to be universally the same, namely, "our status as rational agents," agents defined by a shared potential for deliberative reason. ${ }^{8}$ The idea is that so long as that potential is protected by law, particular forms of its realization-cultural traditions, religious dogmas, ethnic allegiances — can be left to make their way or fail to make their way in the to-and-fro of marketplace debate. A tradition may die, a religion may languish, an ethnic community may fail to secure representation in the classroom or the boardroom; but these consequences are of less moment and concern than the integrity of the process that generates them, a process that values deliberation over the results of deliberation, results that are, from the perspective of this politics, indifferent. ${ }^{9}$

Results or outcomes are not at all indifferent in another politics, named by Taylor the "politics of difference." ${ }^{10}$ The politics of difference, as Taylor explains it, does not merely allow traditions a run for their money; it is committed to their flourishing. If the politics of equal dignity subordinates local cultural values to the universal value of free rational choice, the politics of difference names as its preferred value the active fostering of the unique distinctiveness of particular cultures. It is that distinctiveness rather than any general capacity of which it is an actualization that is cherished and protected by this politics. Whereas the politics of equal dignity "focuses on what is the same in all" and regards particularity as icing on a basically homogeneous cake, the politics of difference asks us "to recognize and even foster particularity" as a first principle."

In practical terms, fostering particularity requires that we make special adjustments to the special requirements of distinctive groups, for if we refuse such adjustments in the name of some baseline measure of rational potential, we weaken the distinctiveness whose recognition is our chief obligation. "Where the politics of universal dignity fought for forms of nondiscrimination that were quite 'blind' to the ways in which citizens differ, the politics of difference often redefines nondiscrimination as requiring that we make those distinctions the basis of differential treatment." ${ }^{12}$ It is the politics of difference that gives us campus speech codes (like Stanford's before it was struck down) that judicialize racist epithets directed against minorities but do not consider epithets directed against Caucasian males (honkey, redneck, whitey) a form of racism (on the reasoning that racism is defined as hostility plus power rather than as mere hostility). It is the politics of difference that leads to the establishment of schools for young black males in 
our inner cities (on the reasoning that the maintenance of cultural and gender homogeneity will bolster confidence and stimulate learning). It is the politics of difference that produces demands by blacks, Asians, and Native Americans that they be portrayed in films and plays by actors who are themselves blacks, Asians, and Native Americans. It is the politics of difference that asks for proportional representation of various cultural traditions in the classroom and in faculty hiring. The politics of difference is the equivalent of an endangered species act for human beings, where the species to be protected are not owls and snail darters, but Arabs, Jews, homosexuals, Chicanos, Italian Americans, and on and on and on.

The politics of difference is what I mean by strong multiculturalism. It is strong because it values difference in and for itself rather than as a manifestation of something more basically constitutive. Whereas the boutique multiculturalist will accord a superficial respect to cultures other than his own, a respect he will withdraw when he finds the practices of a culture irrational or inhumane, a strong multiculturalist will want to accord a deep respect to all cultures at their core, for he believes that each has the right to form its own identity and nourish its own sense of what is rational and humane. For the strong multiculturalist the first principle is not rationality or some other supracultural universal, but tolerance.

But the trouble with stipulating tolerance as your first principle is that you cannot possibly be faithful to it because sooner or later the culture whose core values you are tolerating will reveal itself to be intolerant at that same core; that is, the distinctiveness that marks it as unique and self-defining will resist the appeal of moderation or incorporation into a larger whole. Confronted with a demand that it surrender its viewpoint or enlarge it to include the practices of its natural enemies - other religions, other races, other genders, other classes - a beleaguered culture will fight back with everything from discriminatory legislation to violence.

At this point the strong multiculturalist faces a dilemma: either he stretches his toleration so that it extends to the intolerance residing at the heart of a culture he would honor, in which case tolerance is no longer his guiding principle, or he condemns the core intolerance of that culture (recoiling in horror when Khomeini calls for the death of Rushdie), in which case he is no longer according it respect at the point where its distinctiveness is most obviously at stake. Typically, the strong multiculturalist will grab the second handle of this dilemma (usually in the name of some supracultural universal now seen to have been hiding up his sleeve from the 
beginning) and thereby reveal himself not to be a strong multiculturalist at all. Indeed it turns out that strong multiculturalism is not a distinct position, but a somewhat deeper instance of the shallow category of boutique multiculturalism.

To be sure, there will still be a difference, but it will be a difference in degree. When the novelist Paul Theroux encounters a Pakistani with an advanced degree in science who nevertheless declares "Rushdie must die," he responds in true boutique multiculturalist fashion by setting him "straight" and informing him (as if he were a child) that his "are ignorant and barbarous sentiments." ${ }^{13}$ (I bet that really convinced him!) Contrast this with M. M. Slaughter, a strong multiculturalist who, in the place of name calling, offers an explanation of why an educated Muslim whose sense of identity "is inseparable from the community of believers" might think himself mortally wounded by something written in a book. For Slaughter, the issue is properly understood not as a simple contrast between civilization and barbarity, but as a tension between "essentialist ideologies that inevitably and irreconcilably conflict:... The concept of the autonomous self requires the free speech principle; the socially situated self of Islamic society necessarily rejects free speech in favor of prohibitions against insult and defamation." Yet even while she elaborates the point, Slaughter declines to extend her act of sympathetic understanding into a statement of approval, and she is careful to declare at the beginning of her essay that "the placing of a bounty on Rushdie's head" is "a terroristic act." ${ }^{4}$ Slaughter's judgment, in short, is finally not all that different from Theroux's, although it comes accompanied by an analysis the novelist has no interest in making. Both Theroux and Slaughter-one of whom sees the fatwa as an instance of fanaticism bordering on insanity, while the other pushes through to a comprehension of the system of thought in which the fatwa might constitute a moral obligation-stop far short of going all the way, that is, of saying, with Theroux's Pakistani, "Rushdie must die."

In the end neither the boutique multiculturalist nor the strong multiculturalist is able to come to terms with difference, although their inabilities are asymmetrical. The boutique multiculturalist does not take difference seriously because its marks (quaint clothing, atonal music, curious table manners) are for him matters of lifestyle, and as such they should not be allowed to overwhelm the substratum of rationality that makes us all brothers under the skin. The strong multiculturalist takes difference so seriously as a general principle that he cannot take any particular difference seriously, 
cannot allow its imperatives their full realization in a political program, for their full realization would inevitably involve the suppression of difference. The only way out for the would-be strong multiculturalist is to speak not for difference in general, but for $a$ difference, that is, for the imperatives of a distinctive culture even when they impinge on the freedom of some other distinctive culture.

But if he did that the strong multiculturalist would no longer be faithful to his general principle. Instead he would have become a "really strong" multiculturalist, someone whose commitment to respecting a culture was so strong that he would stay its course no matter what; but that would mean that he wasn't a multiculturalist at all, since if he stuck with the distinctiveness of a culture even at the point where it expressed itself in a determination to stamp out the distinctiveness of some other culture, he would have become (what I think every one of us always is) a uniculturalist. It may at first seem counterintuitive, but given the alternative modes of multiculturalism-boutique multiculturalism, which honors diversity only in its most superficial aspects because its deeper loyalty is to a universal potential for rational choice; strong multiculturalism, which honors diversity in general, but cannot honor a particular instance of diversity insofar as it refuses (as it always will) to be generous in its turn; and really strong multiculturalism, which goes to the wall with a particular instance of diversity and is therefore not multiculturalism at all-no one could possibly be a multiculturalist in any interesting and coherent sense..$^{15}$

\section{Multiculturalism as Demographic Fact}

The reason that this will sound counterintuitive is that multiculturalism and its discontents are all people are talking about these days. Is everyone arguing about something that doesn't exist? An answer to that question will require a fresh beginning to our analysis and the introduction of a new distinction between multiculturalism as a philosophical problem and multiculturalism as a demographic fact. Multiculturalism as a philosophical problem is what we've been wrestling with in the preceding passages, with results not unlike those achieved (if that is the word) by Milton's fallen angels who try to reason about fate, foreknowledge, and free will and find themselves "in wandering mazes lost." ${ }^{\prime 16}$ We too become lost in mazes if we think of multiculturalism as an abstract concept that we are called upon to either affirm or reject. But if we think of multiculturalism as a demographic fact-the fact 
that in the United States today many cultural traditions flourish and make claims on those who identify with them-the impulse to either affirm or reject it begins to look rather silly; saying yes or no to multiculturalism seems to make about as much sense as saying yes or no to history, which will keep on rolling along irrespective of the judgment you pass on it.

Not that there is nothing to say once you have recognized that multiculturalism is a demographic fact; it is just that what you say will have more to do with the defusing of potential crises than the solving of conceptual puzzles. We may never be able to reconcile the claims of difference and community in a satisfactory formula, but we may be able to figure out a way for these differences to occupy the civic and political space of this community without coming to blows. "All societies," Taylor observes, "are becoming increasingly multicultural"; as a result "substantial numbers of people who are citizens" of a particular country are also members of a culture "that calls into question" that country's "philosophical boundaries." "What we "are going to need ... in years to come," Taylor predicts, is some "inspired adhoccery." ${ }^{18}$

I want to take the phrase "inspired adhoccery" seriously. What it means is that the solutions to particular problems will be found by regarding each situation-of-crisis as an opportunity for improvisation and not as an occasion for the application of rules and principles (although the invoking and the recharacterizing of rules and principles will often be components of the improvisation). Any solution devised in this manner is likely to be temporary - that is what ad hoc means - and when a new set of problems has outstripped the solution's efficacy, it will be time to improvise again. It follows then that definitions of multiculturalism will be beside the point, for multiculturalism will not be one thing, but many things; and the many things it will be will weigh differently in different sectors of the society. In some sectors multiculturalism will take care of itself, in others its problematic will hardly register, and in others it will be a "problem" that must be confronted.

It will not, however, typically be a philosophical or theoretical problem. Multiculturalism in the workforce? Projections of demographic patterns indicate that in the forseeable future the workforce will be largely made up of women and minorities; accordingly, corporations have already begun to change their recruiting patterns. It is clear, Corning CEO James Houghton has said, that no company can afford a predominantly white, male workforce. Neither can a company afford a workplace driven by racial and ethnic tensions; and therefore the same bottom-line consideration that is altering hiring and promotion policies is also mandating sensitivity pro- 
grams, a more consultative organizational structure, and decentered management. In short, for the business world it's multiculturalism or die.

The same formula applies, for different reasons, to colleges and universities. When the college population was relatively small and homogeneous it was a matter of neither concern nor surprise that the range of cultural materials studied was restricted to the books produced by earlier generations of that same homogeneous population. But when the GI bill brought many to college who would otherwise not have thought to go, and when some of those newly introduced to the academy found that they liked it and decided to stay on as faculty members, and when the rising tide of feminist consciousness led women to no longer be willing to sacrifice their careers to the ambitions of their husbands, and when a college degree became a prerequisite for employment opportunities previously open to high-school graduates, and when immigration after the Korean and Vietnam wars added large numbers of motivated students to a growing cultural mix, and when pride in ethnic traditions (stimulated in part by the extraordinary impact of the television series Roots) weakened the appeal of the "melting pot" ideal, the pressures to include new materials in the classroom and to ask that they be taught by members of the cultures or subcultures from which they were drawn seemed to come from all directions. Although multiculturalism is sometimes characterized as a conscious strategy devised by insurgent political groups desirous of capturing America's cultural space so that it can be turned over to alien ideas, in fact it is a development that was planned by no one. As an effect it was decidedly overdetermined; and now that it is here, those who wish to turn the clock back will find themselves increasingly frustrated.

To be sure there will always remain a few colleges (like Hillsdale in Michigan) that set themselves up as the brave defenders of the beachheads others have ignominiously abandoned; but by and large, at least in the world of education, multiculturalism is a baseline condition rather than an option one can be either for or against. Indeed, in many facets of American life there is no multiculturalism issue despite the fact that it is endlessly debated by pundits who pronounce on the meaning of democracy, the content of universal rights, the nature of community, the primacy of the individual, and so on. These mind-numbing abstractions may be the official currency of academic discussion, but they do not point us to what is really at stake in the large social and economic dislocations to which they are an inadequate (and even irrelevant) response. In and of themselves they do no genuine 
work, and insofar as they do any work it is in the service of the adhoccery to which they are rhetorically opposed.

I would not be misunderstood as recommending adhoccery; my point, rather, is that adhoccery will be what is going on despite the fact that the issues will be framed as if they were matters of principle and were available to a principled resolution. As we have seen, there are principles aplentyautonomy, respect, toleration, equality-but when they are put into play by sophisticated intelligences the result is not resolution but a sharpened sense of the blind alleys into which they lead us. Here, for example, is Amy Gutmann asking a series of questions to which she apparently thinks there are answers:

Should a liberal democratic society respect those cultures whose attitudes of ethnic or racial superiority ... are antagonistic to other cultures? If so, how can respect for a culture of ethnic or racial superiority be reconciled with the commitment to treating all people as equals? If a liberal democracy need not or should not respect such "supremacist" cultures, even if those cultures are highly valued by many among the disadvantaged, what precisely are the moral limits on the legitimate demand for political recognition of particular cultures? ${ }^{19}$

You will recognize in these questions the interlocking quandaries that led me to conclude that multiculturalism is an incoherent concept, which cannot be meaningfully either affirmed or rejected. But this is not Gutmann's conclusion. In good liberal-rationalist fashion, she regards the difficulties she uncovers as spurs to a greater conceptual effort; and she sets herself the task of coming up with a formulation that will rescue us from a world of entrenched "political battlefields" and point the way to "mutually respectful communities of substantial, sometimes even fundamental, intellectual disagreement. ${ }^{\prime 20}$ What is remarkable about this statement is its reproduction of the dilemmas it claims to resolve and the determined (if unintentional) evasion of the difficulties these dilemmas present. The vocabulary will not stand up to even the most obvious lines of interrogation. How respectful can one be of "fundamental" differences? If the difference is fundamental-that is, touches basic beliefs and commitments-how can you respect it without disrespecting your own beliefs and commitments? And on the other side, do you really show respect for a view by tolerating it, as you might tolerate the buzzing of a fly? Or do you show respect when you take it seriously enough to oppose it, root and branch? 
It is these and related questions that Gutmann begs and even hides from herself by inserting the word "intellectual" between "fundamental" and "disagreement." What "intellectual" does is limit disagreement to matters that can be debated within the decorums of Enlightenment rationalism. Fiercer disagreements, disagreements marked by the refusal of either party to listen to reason, are placed beyond the pale, where, presumably, they occupy the status of monstrosities, both above and below our notice (above our notice when they are disagreements over matters of religion, below our notice when they are disagreements between groups that want not to talk to one another but to exterminate one another). As a result, the category of the fundamental has been reconfigured-indeed, stood on its head-so as to exclude conflicts between deeply antithetical positions; that is, to exclude conflicts that are, in fact, fundamental.

The sleight of hand involved here is nicely illustrated by Gutmann's example of a disagreement that she says can be pursued in the context of mutual respect, the disagreement between the pro-choice and pro-life parties in the abortion debate. It is an example that tells against the principle it supposedly supports; for as everyone knows, strong pro-life advocates regard pro-choicers as either murderers or supporters of murderers, while in the eyes of pro-choicers, pro-life advocates are determined to deprive women of the right to control their own bodies. The disagreement between them is anything but intellectual because it is so obviously fundamental. In an intellectual disagreement the parties can talk to one another because they share a set of basic assumptions; but in a fundamental disagreement, basic assumptions are precisely what is in dispute. Either you can have "fundamental" or you can have "intellectual," but you can't have both; and if, like Gutmann, you privilege "intellectual," you have not honored the level of fundamental disagreement but evaded it.

\section{Hate Speech}

Gutmann does it again when she turns to the vexed issue of campus hate speech. Here the question is, How can we have a community of mutually respectful cultures when it is a practice in some cultures to vilify the members of others? ${ }^{21}$ It looks like an intractable problem; but Gutmann solves it, she thinks, by distinguishing between differences one merely tolerates and differences one respects. You respect a difference when you see it as a candidate for serious moral debate; it has a point even though it is not your point. 
But some differences are asserted so irrationally that debate is foreclosed; and those differences, while they must be tolerated in a free society, must also be denounced by all right-thinking persons. Hate speech-speech directed against women, Jews, blacks, and gays-falls into the second category; it is "indefensible on moral and empirical grounds." 22

This seems neat and satisfying until one realizes that the "moral and empirical grounds" on the basis of which the arguments of certain speakers are judged "indefensible" have not been elaborated. Rather, they are simply presupposed, and presupposed too is their normative status. In effect Gutmann is saying, "Well, everybody knows that some assertions just aren't worth taking seriously." This is the result of withdrawing the offending opinions from the circle of rationality: one turns a blind eye toward the impact they might have on the world by assuming - without any empirical evidence whatsoever-that they will have none, that only crazy people will listen to crazy talk. With that assumption in place-and it is in place before she begins-the community of mutually respectful disputants has been safely constituted by the simple strategy of exiling anything that might disturb it. No wonder that within its confines disputants exercise mutual respect, since mutuality (of an extremely pallid kind) has been guaranteed in advance, as problems are "solved" by being defined out of existence. ${ }^{23}$ Once hate speech-a designation its producers would resist-has been labeled "radically implausible" ${ }^{24}$ (and "plausibility" added to the abstractions whose essentialist shape Gutmann blithely assumes), it is no more threatening than a belch or a fart: something disagreeable, to be sure, but something we can live with, especially since the category of the "we" has been restricted to those who already see things as Gutmann does.

In the end, the distinction between what is to be respected and what is tolerated turns out to be a device for elevating the decorum of academic dinner parties to the status of discourse universals while consigning alternate decorums to the dustbin of the hopelessly vulgar. In the expanded edition of the volume she edits, Gutmann is joined by Jürgen Habermas, who declines to admit religious fundamentalists into his constitutional republic because they "claim exclusiveness for a privileged way of life" and are therefore unfit for entry into "a civilized debate ... in which one party can recognize the other parties as co-combatants in the search for authentic truths." ${ }^{25}$ Of course, religious fundamentalists begin with the conclusion that the truths they hold are already authentic, but that is precisely why they will be denied entry to the "ideal speech" seminar when it is convened. (I hear you knocking but you 
can't come in.) Fundamentalists and hate speakers might seem an odd couple; what links them and makes them candidates for peremptory exclusion is a refusal to respect the boundaries between what one can and cannot say in the liberal public forum. (You can't say "kike" and you can't say "God.") Although the enemies named by Gutmann and Habermas are different, they are dispatched in the same way, not by being defeated in combat but by being declared ineligible before the fight begins.

The result is the kind of "civilized" conversation dear to the hearts of academic liberals who believe, on the model of the world-as-philosophy-seminar, that any differences between "rational" persons can be talked through. It is finally a faith in talk-in what liberals call "open and inclusive dialogue" - that underwrites a program like Gutmann's. But the dialogue is not really open at all, as we can see when she sets down the requirements for entry: "Mutual respect requires a widespread willingness and ability to articulate our disagreements, to defend them before people with whom we disagree, to discern the difference between respectable and disrespectable disagreement, and to be open to changing our own minds when faced with well-reasoned criticism." ${ }^{26}$ Words like "widespread" and "open" suggest a forensic table to which all are invited, but between them is the clause that gives the lie to the apparent liberality - "to discern the difference between respectable and disrespectable disagreement" - which means of course to decide in advance which views will be heard and which will be dismissed. It is a strange openness indeed that is defined by what it peremptorily excludes.

It is not my intention, however, to fault Gutmann for not being open enough. Quite the reverse. It is her desire to be open that is the problem because it prevents her from taking the true measure of what she recognizes as an evil. If you wish to strike a blow against beliefs you think pernicious and "fraught with death" (the phrase is Oliver Wendell Holmes's in Abrams v. United States), ${ }^{27}$ you will have to do something more than exclaim, "I exclude you from my community of mutual respect." That kind of exclusion will be no blow to an agenda whose proponents are not interested in being respected but in triumphing. Banishing hate speakers from your little conversation leaves them all the freer to pursue their deadly work in the dark corners from which you have averted your fastidious eyes. Gutmann's instinct to exclude is the right one; it is just that her gesture of exclusion is too tame-it amounts to little more than holding her nose in disgust-and falls far short of wounding the enemy at its heart. A deeper wound will only be inflicted by methods and weapons her liberalism disdains: by acts of ungenerosity, intolerance, 
perhaps even repression, by acts that respond to evil not by tolerating it-in the hope that its energies will simply dissipate in the face of scorn-but by trying to stamp it out. This is a lesson liberalism will never learn; it is the lesson liberalism is pledged never to learn because underlying liberal thought is the assumption that, given world enough and time (and so long as embarrassing "outlaws" have been discounted in advance), difference and conflict can always be resolved by rational deliberation, defined of course without consulting those who have been excluded from it.

I remarked earlier that producers of what is called hate speech would not accept that description of their words, words that they would hear as both rational and true. In arguments like Gutmann's and Habermas's, rationality is a single thing whose protocols can be recognized and accepted by persons of varying and opposing beliefs. In this model (as in Rockefeller's) differences are superficial, and those who base political and social judgments on them are labeled irrational. But if rationality is always differential, always an engine of exclusion and boundary making, the opposition is never between the rational and the irrational, but between opposing rationalities, each of which is equally, but differently, intolerant. This leads to the perhaps startling but inevitable conclusion that hate speech is rational and that its nature as a problem must be rethought. Indeed, it is only when hate speech is characterized as irrational that the label "problem" seems appropriate to it, and also comforting, because a problem is something that can be "treated," either by benign neglect (don't worry, it's a fringe phenomenon that will never catch on), by education and dialogue (the answer to hate speech is more speech: remember Theroux and the Pakistani), or, in a darker view of the matter, by quarantine and excommunication (you have a disease and while we won't exterminate you, neither will we have anything to do with you). This is the entire spectrum of remedies in the liberal pharmacy, which can only regard hate speech as something we can live with or something we can cure or something we can't cure but can avoid by refusing to join a militia.

It is in relation to this spectrum that speech codes seem obviously counterproductive, either because they are an overly strong response to a minor irritant, because they stand in the way of the dialogue that will lead to health, or because they will only reinforce the paranoia that produced the problem in the first place. Everything changes, however, once hate speech is seen not as evidence of some cognitive confusion or as a moral anomaly, but as the expression of a morality you despise, that is, as what your enemy (not the universal enemy) says. ${ }^{28}$ If you think of hate speech as evidence of moral or 
cognitive confusion, you will try to clean the confusion up by the application of good reasons; but if you think that hate speakers rather than being confused are simply wrong - they reason well enough, but their reasons are anchored in beliefs (about racial characteristics, sexual norms, and so on) you abhor-you will not place your faith in argument but look for something stronger. ${ }^{29}$ The difference between seeing hate speech as a problem and seeing it as what your enemy says is that in response to a "problem" you think in terms of therapy and ask of any proposal, "Will it eliminate the pathology?"; whereas in response to what your enemy says, you think in terms of strategy and ask of any proposal, "Will it retard the growth of the evil I loath and fear?"

The advantage of this shift is that it asks a real question to which there can be a variety of nuanced answers. When you ask, as liberals always do, "Will speech codes dispel racism and remove prejudice from the hearts of those who now display it?" the answer can only be "no," which I would say points not to the inadequacy of speech codes, but to the inadequacy of the question. The demand that speech codes dispel racism trades on the knowledge (which I share with antiregulation liberals) that racism cannot be altered by external forces; it is not that kind of thing. But the fact that it is not that kind of thing does not mean that there is nothing to be done; it merely means that whatever we do will stop short of rooting out racism at its source (as we might succeed in doing if it were a disease and not a way of thinking) and that the best we can hope for is a succession of tactical victories in which the enemy is weakened, discomforted, embarrassed, deprived of political power, and on occasion routed. (My phrase "the enemy" might suggest that I was referring to everyone's enemy and slipping back into a liberal univeralism, in which anomalous monsters are clearly labeled and known to everyone; but my use of the phrase marks the point at which I come out from behind the arras of analysis and declare my own position, which rests not on the judgment that racism doesn't make any sense [it makes perfect sense if that's the way you think] but that it makes a sense I despise. I am now reaching out to readers who are on my side and saying if you want to win — and who doesn't?- - do this.)

This, however, is not a small basket of hopes, and what's more, the hopes are realizable. If you think of speech codes not as a magic bullet capable of definitive resolution, but as a possible component of a provisional strategy, you no longer have to debate them in all-or-nothing terms. You can ask if in this situation, at this time and in this place, it would be reasonable to deploy 
them in the service of your agenda (which, again, is not to eliminate racism, but to harrass and discomfort racists). The answer will often be "no," and, in fact, that is my usual answer. In most cases speech codes will cause more problems than they solve; and, all things considered, it will often be the better part of wisdom to tolerate the sound of hate and murmur something about sticks and stones and the value of free expression. At that moment you will be talking like a liberal, but there's nothing wrong with that as long as you don't take your liberalism too seriously and hew to it as a matter of principle. ${ }^{30}$ Just as speech codes become thinkable once they are no longer asked to do impossible things, so do liberal platitudes become usable when all you want from them is a way of marking time between the battles you think you can win. Switching back and forth between talking like a liberal and engaging in distinctly illiberal actions is something we all do anyway; it is the essence of adhoccery. Perhaps if we did it with less anxiety, we might do it better. We might even be inspired.

\section{Notes}

1. See Tom Wolfe, Radical Chic and Mau-Mauing the Flak Catchers (New York: Farrar, Straus and Giroux, 1970).

2. See Employment Div., Dept. of Human Resources of Oregon et al., v. Smith et al., 494 U.S. 872 (1990), in which Native Americans were denied exception for the religious use of peyote.

3. John Milton, "Areopagitica," in The Prose of John Milton, ed. J. Max Patrick (Garden City, N.Y.: Doubleday, 1967), 322.

4. Steven C. Rockefeller, "Comment," in Multiculturalism and "The Politics of Recognition": An Essay by Charles Taylor, with Commentary by Amy Gutmann, Steven C. Rockefeller, Michael Walzer, and Susan Wolf, ed. Amy Gutmann (Princeton: Princeton University Press, 1992), 88.

5. Rockefeller, 88 .

6. Some political theorists go so far as to insist not merely that religious reasons be disallowed in the public forum, but that citizens should not advocate or vote for any position unless their motives are "adequately secular." Robert Audi, "The Separation of Church and State and the Obligations of Citizenship," Philosophy and Public Affairs 18 (Summer 1989): 280. See also the full discussion of the question in Kent Greenawalt, Private Consciences and Public Reasons (Oxford: Oxford University Press, 1995).

7. Rockefeller, 87.

8. Charles Taylor, "The Politics of Recognition," in Multiculturalism and "The Politics of Recognition," 38,41 . 
9. John Rawls puts it this way: "The state is not to do anything that makes it more likely that individuals accept any particular conception rather than another." John Rawls, Political Liberalism (New York: Columbia University Press, 1993), 193. Rawls acknowledges that "some conceptions will die out and others survive only barely," but this, he says, is inevitable because "no society can include within itself all forms of life" (a statement made with all the complacency of someone who knows that his form of life will certainly be included in his society). Rawls, 197.

10. Taylor, "Politics," 38.

11. Taylor, "Politics," 43.

12. Taylor, "Politics," 39.

13. Paul Theroux, letter to Salman Rushdie, in The Rushdie Letters: Freedom to Speak, Freedom to Write, ed. Steve MacDonogh (Lincoln, Nebr.: University of Nebraska Press, 1993), 33.

14. M. M. Slaughter, "The Salman Rushdie Affair: Apostasy, Honor, and Freedom of Speech," Virginia Law Review 79 (February 1993): 198, 156, 155, 154.

15. For evidence I might point to Multiculturalism: A Critical Reader, ed. David Theo Goldberg (Cambridge, Mass.: Blackwell, 1994), a volume in which the contributors wrestle unsuccessfully with the conundrums I have been explicating. Some of the essays urge something called critical multiculturalism, which Peter McLaren glosses as the "task of transforming the social, cultural, and institutional relations in which meanings are generated" (Peter McLaren, "White Terror and Oppositional Agency: Toward a Critical Multiculturalism," 53). This is to be done in the service and name of heterogeneity (see Goldberg, "Introduction: Multicultural Conditions," 25-31), but just where is heterogeneity to be located? Whose heterogeneity (read "difference") is it? If it is located somewhere, then it is not heterogeneity. If it is located everywhere, then it is universalist liberalism all over again, and the supposed enemy has been embraced.

The Chicago Cultural Studies Group tries to finesse this dilemma by urging full disclosure. One should "indicate the goal of one's knowledge production" and thereby "disrupt one's claim to academic authority and authorial self-mastery." Chicago Cultural Studies Group, "Critical Multiculturalism," Critical Inquiry 18 (Spring 1992): 549; report in Multiculturalism, 114-391. But by now this gesture is a claim to authority and signifies mastery and control even as they are disowned in search of a "better standpoint for substantive critique" (Chicago Cultural Studies Group, 549). The authors can only conclude that "a genuinely critical multiculturalism cannot be brought about by good will or by theory, but requires institutions, genres, and media that do not yet exist" (Chicago Cultural Studies Group, 553). They never will.

16. John Milton, Paradise Lost, in John Milton, ed. Stephen Orgel and Jonathan Goldberg (Oxford: Oxford University Press, 1990), bk. 2, 1.561, p. 389.

17. Taylor, "Politics," 63.

18. Charles Taylor, "The Rushdie Controversy," Public Culture 2 (Fall 1989): 121.

19. Amy Gutmann, "Introduction," Multiculturalism and "The Politics of Recognition," 5. 


\section{Gutman, 20.}

21. This is a standard question in discussions of multiculturalism from a liberal perspective. Will Kymlicka asks it in Multicultural Citizenship (Oxford: Clarendon Press, 1995), 94: "How should liberals respond to illiberal cultures?" His answer is that since liberals should eschew illiberal practices, they "should not prevent illiberal nations from maintaining their societal culture, but should promote the liberalization of these cultures" (Kymlicka, 94-95). In other words, respect the culture by trying to change it. In his inability to see the contradiction between maintaining a tradition and setting out to soften it and blur its edges, Kymlicka enacts the dilemmas traced out in the first part of this essay. He is trying to be a strong multiculturalist, but turns boutique when the going gets tough. He would reply that by "promote" he means persuade rather than impose and that rational persuasion is always an appropriate decorum. "Hence liberal reformers inside the culture should seek to promote their liberal principles through reason or example, and liberals outside should lend their support to any efforts the group makes to liberalize their culture" (Kymlicka, 168). The key word is "reason," which for Kymlicka, as for Rockefeller, is a standard that crosses cultural boundaries and will be recognized by all parties (except those that are nuts). But reasons of the kind liberals recognizeabstract, universal, transhistorical-are precisely what the members of many so-called illiberal cultures reject. The application of "reason" in an effort to persuade is not the opposite of imposition, but a version of it.

22. Gutman, 23.

23. Rawls makes essentially the same move in Political Liberalism when he acknowledges that "prejudice and bias, self and group interest, blindness and willfulness, play their all too familiar part in political life," but he insists that these "sources of unreasonable disagreement stand in marked contrast to those compatible with everyone's being fully reasonable" (Rawls, 58). One must ask, how does the contrast get marked? And the answer is, from the perspective of a predecision to confine reasonable disagreements to those engaged in by coolly deliberative persons. The irony is that "prejudice," "bias," "blindness," and "willfulness" are instances of name calling, just the kind of activity Rawls wants to avoid. These words stigmatize certain kinds of argument in advance and remove them peremptorily from the arena of appropriate conversation. Susan Mendus neatly illustrates the strategy in a single brief sentence: "Prejudice and bigotry, not moral disapproval, are the hallmarks of racism." Susan Mendus, Toleration and the Limits of Liberalism (Atlantic Highlands, N.J.: Humanities Press International, 1989), 15. The assertion is that racists (another instance of name calling) have no arguments, only primitive biases. The assertion works if you accept its first (unstated) premise: only arguments that are abstract and universal are really arguments; all others are mere prejudice. This leaves the field of "moral disputation" to those who have already rejected as accidental or regrettable any affiliations or commitments based on race or ethnicity. Moral dispute will then go on in the same sanitized forum marked out by Gutmann's distinction between views you tolerate (but don't deign to argue with) and views you respect. The alternative would 
be to see that prejudice - that is, partiality — is a feature of any moral position, including the liberal one championed by Gutmann, Rawls, and Mendus, and that what you want to say about those who devalue persons on the basis of race is not that they are outside the arena of moral debate but that theirs is a morality you think wrong, evil, and dangerous (provided of course that is what you think).

\section{Gutman, 22.}

25. Jürgen Habermas, "Struggles for Recognition in the Democratic Constitutional State," in Multiculturalism: Examining the Politics of Recognition, ed. Amy Gutmann (Princeton, N.J.: Princeton University Press, 1994), 133; emphasis mine. As Larry Alexander points out, "An actual dialogue test is, in effect, a requirement of unanimity." That is, participants must already agree as to what is appropriate and what is not; but agreement is supposedly the goal of the dialogue, and if it is made a requirement for entry (in the manner of Gutmann and Habermas) the goal has been reached in advance by rigging the context. Success is then assured; but it is empty because impediments to it have been exiled in advance, even though they surely exist in the world. Larry Alexander, "Liberalism, Religion, and the Unity of Epistemology," San Diego Law Review 30 (Fall 1993): 782.

26. Gutman, 24.

27. Abrams v. United States, 250 U.S. 616 (1919).

28. Liberalism requires a universal enemy so that its procedures of inclusion and exclusion can be implemented in the name of everyone. If, however, there is no universal enemy but only enemies (mine or yours), procedures will always be invoked in the name of some and against some others. The unavailability of a universal enemy is something liberal thinkers are always running up against. They respond typically either by just stipulating someone's enemy as universal (as Gutmann does) or by giving up the attempt to identify an enemy and regarding everyone as potentially persuadable to the appropriate liberal views. (This might be thought of as sentimental or sappy multiculturalism.) See on these points Ellen Rooney's Seductive Reasoning: Pluralism as the Problematic of Contemporary Literary Theory (Ithaca, N.Y.: Cornell University Press, 1989), especially her discussion of the theoretical dream of general persuasion.

29. Since Gutmann identifies virtue with the capacity for rational deliberation, she will assume that hate speakers are deficient reasoners; but in fact they will often have cognitive abilities as strong as anyone's, and they will be able to answer reason with reason. As Richard Rorty has put it in the context of the familiar demand that we be able to prove to a Nazi that he is wrong: "Attempts at showing the philosophically sophisticated Nazi that he is caught in a logical ... self-contradiction will simply impel him to construct ... redescriptions of the presuppositions of the charge of contradiction." Richard Rorty, "Truth and Freedom: A Reply to Thomas McCarthy," Critical Inquiry 16 (Spring 1990): 637.

30. One way of characterizing this essay would be as an attack on principle, or, more precisely, "neutral principle" as it is commonly sought in legal and social contexts. A neutral principle is one you would be willing to apply no matter what the circumstances or 
the interests involved. The trouble with a neutral principle is either that so much content has been eliminated on the way to formulating it that it is empty or that it retains the content of an agenda that will now be able to present itself politically and rhetorically as universal. Liberalism of the kind urged by Gutmann, Rawls, Kymlicka, Rockefeller, and Mendus displays both these liabilities, liabilities that are really advantages to a position that will not or cannot face its contradictions.

The alternative to the neutral principle is a real principle, a principle rooted in a moral conviction (of which racism, sexism, and homophobia would be examples) that you either accept or reject. From the vantage point of a real principle, you don't say to your enemy, "You're not respecting the decorum of enlightened argument"; you say, "You are wrong." Lauren Berlant and Michael Warner complain that there is "no rhetoric available in the national media to throw the right into a ... defensive ambivalence." Lauren Berlant and Michael Warner, "Introduction to 'Critical Multiculturalism," in Multiculturalism: A Critical Reader, 111. If this is true it is because Berlant and Warner, like other liberals and leftists, agree to play in the arena of principle marked out by universals like "free inquiry, open intellectual discussion, and respect for individuals" (Berlant and Warner, 111). In this arena they will always lose because those words, as currently deployed, rule out in advance the agendas they might wish to promote. What they should do is not fight over title to that vocabulary, but just drop it and say that those who currently wrap themselves in it are wrong and dangerous.

On the question of principle and what I term its immorality, see Stanley Fish, "At the Federalist Society," Howard Law Journal 39 (Spring 1996), and the excellent discussion in Larry Alexander and Ken Kress, "Against Legal Principles," Law and Interpretation: Essays in Legal Philosophy, ed. Andrei Marmor (Oxford: Oxford University Press, 1995), 279-327. See especially page 325 , where the authors observe that since arguments of principle require officials systematically to disregard both their own moral convictions and the moral convictions of those they disagree with, "they must do what is unjust from everyone's perspective." Their conclusion is mine: "Surely this is a perverse requirement." 


\section{Part II}

Multiculturalism and the Principles of Democracy 
This page intentionally left blank 


\title{
Chapter 5
}

\section{Constitutionalism and Multiculturalism}

\author{
Walter Berns
}

\begin{abstract}
Hath not a Jew eyes? hath not a Jew hands, organs, dementions, sences, affections, passions, fed with the same foode, hurt with the same weapons, subject to the same diseases, healed by the same meanes, warmed and cooled by the same Winter and Sommer as a Christian is; if you pricke us doe we not bleede? If you tickle us, doe we not laugh? if you poison us doe we not die? and if you wrong us shall we not revenge? if we are like you in the rest, we will resemble you in that.

- William Shakespeare, The Merchant of Venice
\end{abstract}

Alexis de Tocqueville, writing in the 1830s, very much feared that liberty and equality would be at war with each other; today there is a tendency among some intellectuals to think that peace between them can be achieved by combining them under the label cultural pluralism. Cultural pluralism implies equality, we are told, and equality implies freedom for the various elements (mainly religious opinions and ethnic groups) being combined. It also implies - indeed, it is said to require-a "nonideological state," or an ideologically neutral state; and it is only a short step from this to say that such a state is obliged to promote "multiculturalism" by making it a part, in fact the organizing principle, of the public school curriculum, for example. In such a curriculum all "cultures" are to be treated as equal, or as equally deserving of respect. But there is a question as to whether multiculturalism is compatible with the principles of the Constitution and, therefore, capable of providing a foundation for what is said to be the cultural pluralism we have long enjoyed in this country. Whether it is compatible depends on what is meant by culture.

Although not the first to use the term in its modern sense, Thomas Carlyle (in the 1860s) spoke of culture as the body of arts and learning separate from the "work" of society. This definition has the merit of reflecting (and that very 
clearly) the problem that gave rise to the idea of culture and the attempt to define it in the early nineteenth century. Carlyle was preceded by Coleridge, Keats, Shelley, and Wordsworth, who, in his role as poet, saw himself as an "upholder of culture" in a world that disdained it; and by John Stuart Mill, for whom culture meant the qualities and faculties that characterize our humanity, or those aspects of humanity that he foresaw would be missing in a utilitarian society. Carlyle was followed by Matthew Arnold, for whom culture meant not only literary pursuits but-in a sentence that became familiar if not famousthe pursuit of "the best which has been thought and said in the world."

What these critics had in common was a concern for the sublime (or the aesthetic) and a complaint against the modern democratic and commercial society in which it had no firm place. The founders of this modern societysay, John Locke and Adam Smith-promised to provide for the needs of the body (and in this they surely succeeded); culture was intended to provide for the needs of the soul—Coleridge, for example, made this the business of his "clerisy." As Allan Bloom put it, "only when the true ends of society have nothing to do with the sublime does 'culture' become necessary as a veneer to cover the void."

The proponents of multiculturalism have something different in mind when they speak of culture. Introducing Charles Taylor's essay on the subject, political scientist Amy Gutmann says that public institutions, "including government agencies, schools, and liberal arts colleges and universities, have come under severe criticism these days for failing to recognize or respect the particular cultural identities of citizens." She mentions specifically African Americans, Asian Americans, Native Americans, and women. ${ }^{3}$ Culture here seems to mean not "the best which has been thought or said in the world," which, as such, might serve (as Shakespeare's plays and poems have served) to civilize and, in some way, even to unify peoples; rather, culture here seems to mean the different customs, ways, mores, or morals/manners-moeurs, as Tocqueville called them — of peoples, groups, and (if we are to believe Amy Gutmann) even the sexes. Thus, in the body of his essay, Taylor refers specifically to the French Canadians, whose moeurs are not those of the English Canadians and for which the former demand recognition. Demand it and apparently deserve it, not because their culture is superior in Matthew Arnold's sense to that of the English Canadians but simply because it is theirs.

No country has done more to recognize the diversity of morals/manners than Canada; it even has a (federal) Department of Multiculturalism and 
Citizenship and provides generous subsidies for "ethnic' music, painting, dance, drama, museums, etc." Initiated in the 1970s by Prime Minister Pierre Elliott Trudeau, the department had the purpose "to add to the cultural richness of Canadian life by assisting the smaller ethnic groups [that is, groups other than the English and French Canadians] to maintain certain of their traditional cultural forms and a distinct sense of identity, if such was their desire." These diverse groups were to form the Canadian "mosaic." But it is one thing to provide subsidies for folk-dancing groups and ethnic cooking and quite another to allow these groups, without exception, to retain their "cultural identities." The feasibility of the latter program would surely depend on what it is in their culture that they want to retain. After all, to the extent that they allow some groups to retain their cultural identities, they will inherit some nasty ethnic rivalries.

Nevertheless, Canadians speak of multiculturalism as a form of Canadian nationalism "that will convert ethnic rivalries from one of the problems or weaknesses of a society into one of its strengths." ${ }^{\text {" }}$ But success here will depend, to some extent at least, on a strengthening of national identity and a corresponding weakening of ethnic identity, a subject I'll have more to say about in due course. But how does a government intend to go about converting its Serbs and Croats, for example, into Canadians? Not, surely, by policies designed to refurbish and strengthen their memories or otherwise preserve their traditions. Better that they forget their history, lest they be led to repeat it in Canada. ${ }^{6}$ And they can be led to forget it only by being taught that Canada is something more than the sum of its diverse parts and something better than any of its parts. This, of course, is what the United States set out to do in 1787, except that its "parts" were understood to be individuals with rights, not groups making up a "mosaic."

The framers of our Constitution never spoke of multiculturalism, cultural pluralism, or, for that matter, even of pluralism. Such terms were not part of their political vocabulary. ${ }^{7}$ Nor were they sanguine about the possibility of combining cultures. Instead, as the following passage from Federalist 2 indicates, they were sanguine about our prospects only because we were (or were said to be) united in all essential respects:

Providence has been pleased to give this one connected country to one united people-a people descended from the same ancestors, speaking the same language, professing the same religion, attached to the same principles 
of government, very similar in their manners and customs, and who, by their joint counsels, arms, and efforts, fighting side by side throughout a long and bloody war, have nobly established their general liberty and independence.

The same concern for unity, or a similarity of manners, customs, and, above all, opinion concerning the principles of government is reflected in the early statements and congressional debates having to do with immigration and naturalization. These debates took place in 1790 and 1794, and everyone who addressed the issue favored population growth and, to that end, a liberal immigration policy; but, at the same time, everyone recognized the importance of excluding the immigrant who, in Madison's words, could not readily "incorporate himself into our society," or, as Theodore Sedgwick put it, would not "mingle [here] in social affection with each other, or with us," or, finally, "would not be attached to the principles of the government of the United States." ${ }^{\prime \prime}$ As Jefferson said, "Every species of government has its specific principles [and] ours perhaps are more peculiar than those of any other in the universe." He, of course, knew nothing of those who would be of concern to later generations of politicians, the fascists and communists; he was concerned with monarchists and even the immigrants who had been ruled by monarchs. He was afraid that they would bring with them "the principles of the governments they leave, imbibed in their early youth; or, if able to throw them off, it [would] be in exchange for an unbounded licentiousness, passing, as is usual, from one extreme to another." Those principles, he continued, they might transmit to their children. "In proportion to their numbers, they will share with us the legislation [and] will infuse into it their spirit, warp and bias its directions, and render it a heterogeneous, incoherent, distracted mass."

Thus, rather than seeing advantages of diversity, the framers wanted immigrants to be assimilated, incorporated into "our society," with a view to maintaining a population whose members would be attached to the same "principles of government." (As Jefferson put it, a "homogeneous" society would be "more peaceful [and] more durable." ${ }^{\circ}$ ) They had no idea of accommodating a variety of disparate "cultures." From all that appears, they would have thought that impossible.

What we see as cultural differences, they saw as religious differences. Indeed, they probably would have agreed with one of his critics that Horace Kallen (who was the first to use the term "cultural pluralism") did not take culture seriously precisely because he did not appreciate its religious foundations: 
If we think of culture not superficially in terms of graphic arts, music or literature, but as the firm cradle of custom in which the baby is laid and which inevitably forms his emotional life, his food habits, his language, his thoughts, his skills, his sexual life, his work, and his moral values, the envisioned fluid "cultural mobility" becomes rather incredible. One cannot be brought up in all languages, all family patterns, all religions. ${ }^{11}$

Since our constitutional principles are most evident in those provisions dealing with religion, for the purposes of this essay cultural pluralism, at least initially, will mean religious pluralism. Besides language (and political memories), what distinguishes the French from the English Canadians save religion? Is it possible that the culture in multiculturalism-especially when it is taken seriously-means religion, or at least has its ultimate source in religion? After all, as Shakespeare's Shylock indicates (see the epigraph above), we are one with respect to the body and its passions but many only with respect to our memories and our manners/morals, whose source is in our political and religious (or irreligious) beliefs. Understanding the conditions of our religious pluralism will shed some light on the possibility-or better, the impossibility —of multiculturalism.

In 1776, we declared ourselves a "new order of the ages," the first nation in all of history to build itself on the self-evident truth that all men are created equal insofar as they are equally endowed by Nature's God with the unalienable rights to life, liberty, and the pursuit of happiness. The purpose of government, we then said, was "to secure these rights." This was to be done-because, given our principles, it had to be done-only with the consent of the governed.

But it was understood by the framers of the Constitution that the governed would not always agree on the definition of rights, or on how rights were to be secured, or on whose rights deserved to be secured or, in the event of a conflict, preferred; in fact, the framers expected the people to have sharply different views on these matters. Thus, the "one people" that declared its independence in 1776 and the "we the people" that constituted a government in 1787-88 in order to secure those rights would, as a matter of course, thereafter be divided into factions, and unless steps were taken to avoid it, warring factions. According to James Madison (writing in number 10, the most frequently quoted and celebrated of the Federalist Papers), "the latent causes of faction are ... sown in the nature of man," and by definition these factions have interests "adverse to the rights of other citizens, or to the permanent and aggregate interests of the community." 
Given these conditions, the securing of equal rights would not be an easy matter; it would be especially difficult because Nature, so equitable in its endowment of rights, was by no means equitable in its endowment or distribution of talents or faculties, particularly, as Madison put it, the "faculties of acquiring property." Still, he did not hesitate to say that protecting these "different and unequal faculties"-naturally different and naturally unequal-was "the first object of government." The consequence of securing the equal rights of unequally endowed human beings would be a society divided between "those who hold and those who are without property." It followed for him that the regulation of these property factions-creditors, debtors, and landed, manufacturing, mercantile, moneyed, and "many lesser interests" - would be the "principal task of modern legislation." Unlike the others-for example, religious factions - these property factions could be regulated (and accommodated) because, although divided one from another, they shared a common interest in economic growth, and to promote this growth would be the task of modern legislation. America's business would be (as Calvin Coolidge many years later said it was) business.

Madison proved to be a poor prophet with respect to the "business" that occupied the country during the first half and more of the nineteenth century. From 1819-when Congress began to debate the Missouri question, through the years of the Mexican War (and the Wilmot Proviso it provoked), the compromise of 1850, the Kansas-Nebraska Act of 1854 (and the "Bloody Kansas" it provoked), and the Dred Scott decision of 1857, to the Civil War and Reconstruction-Congress, and indeed the entire country, was principally concerned with an issue that Madison neglected to mention in Federalist 10, namely, the slavery issue and the factions it aroused.

To judge from what he wrote in Federalist 56, he expected (or hoped) that time would resolve this "multicultural" issue. "At present," he wrote, some of the states, and especially the southern states, were little more than societies of husbandmen. Few of them, he went on, "have made much progress in those branches of industry which give a variety and complexity to the affairs of a nation." But he expected this would change in time; with time would come a diversification of the state economies, which, if true, would relieve the southern states of their dependence on slave labor, with the result that slavery would cease to be, or would not become, an issue in national politics. In fact, of course, it became the issue in national politics, and the Madisonian system proved incapable of resolving it. Had he foreseen this, Madison might have said in 1788 what Abraham Lincoln said in 
1858 (and, of course, Lincoln was quoting the Bible), namely, that "a house divided against itself cannot stand," which, until proven otherwise, can stand as our definitive statement on the possibility of multiculturalism.

The question then arises as to why Madison was so confident that the other sorts of factions that he identified, particularly religious factions, would not require legislative "regulation." Or, to speak more plainly, why did he think this modern "civilized" nation would be able to avoid the religious problem? That had not been true in the past, especially in the Britain whose history he knew so well, and it is not true everywhere now. In the Britain he knew religion had given rise not only to factions but to civil war and revolution. Why was he confident that this would not be the case in America?

The answer is that the Constitution took religion out of politics, thereby making legislative regulation unnecessary. By separating church and state, specifically, by guaranteeing the free exercise of every religion while favoring none, the Constitution guarantees a proliferation of religious sects, a plurality or "multiplicity of sects," as Madison puts it in Federalist 51, none of them capable of constituting a legislative majority. The various sects will have to live with each other; more to the point, as merely one among many, each sect will be required to forgo any attempt to impose its views on the others. The government itself will be neutral in religious matters, and this makes it possible to say that almost anybody, and of any religious persuasion-or, at least, nominally of any religious persuasion-can become an American. All we require is a pledge of allegiance "to the flag of the United States and to the republic for which it stands," implying (especially nowadays) that anybody can make the promise and that no one will have difficulty keeping it.

In saying this, however, we tend to forget the restrictions we used to impose - on Chinese immigration, for example — or the limits we in fact used to enforce. Until recently, that pledge of allegiance was understood to imply a renunciation even of certain political opinions-for example, the advocacy of the overthrow of government by force or violence. It was only in 1974 that the Supreme Court held that members of the Communist party could not be kept off the ballot for refusing to take an oath renouncing such advocacy. ${ }^{12}$ Nor was our record much different with respect to religious opinion, and this despite the First Amendment. For example, our toleration did not extend so far as to embrace the Mormons and their practice of plural marriages. "To call [the advocacy of bigamy and polygamy] a tenet of religion is to offend the common sense of mankind," the Supreme Court said 
in $1890 .{ }^{13}$ When, a few years earlier, Abraham Lincoln was asked what he would do about the Mormons, he replied that he proposed "to let them alone"; but his Democratic adversary, Senator Stephen A. Douglas, campaigned to keep them out-by keeping Utah out-of our union.

But all this is history, a history that many of us would prefer to forget; today no one has reason to be concerned about the communists, and no one publicly advocates polygamy (to say nothing of slavery). It is, of course, true that the Constitution is not altogether neutral respecting religion. It counts the years in a Christian manner (see Article VII), and it recognizes, at least for one purpose, Sunday as the Sabbath (see Article I, section 7); but the non-Christians have learned to live with this. Speaking for a Supreme Court majority, Justice George Sutherland once said, "We are a Christian people"; ${ }^{14}$ but that was in 1931, and no one-at least, no one in an official capacity - would say that today. Instead, we are inclined to speak of "our Judeo-Christian tradition," and if there were to be, as there has been in Britain, a great increase in the number of Muslims among us, I have no doubt that our multiculturalists would happily adapt this to read "our Judeo-Islamic-Christian tradition.”

The situation in Britain is worth describing because, while interesting in itself, it also serves to remind us of the persistence of the religious issue and the difficulties facing a multicultural society. Britain has a religious problem today, and not simply because, unlike us, they do not separate church and state. By law, the Church of England remains the established church: its archbishop of Canterbury retains his precedence, even over the prime minister, and only its doctrines are protected by the law of blasphemy. Despite this, the British might claim to be a pluralist society, in practice if not in principle. They began in 1689 by tolerating most Protestants, including the Quakers, and over the course of the years-which, in the event, proved to be centuries-have extended this privilege to Roman Catholics, Jews, and every variety of Protestant. In theory, there remains, as there was in 1689, a majority church, but only 2.3 percent of the population now attend its services on any given Sunday. The Queen, an Anglican in England and a Presbyterian in Scotland, might attend "chapel" services in Wales, a Roman Catholic mass in Liverpool—or, I suspect, even recite the Kaddish at a Jewish burial service-without arousing public comment.

Under the 1944 Education Act, religious minorities were permitted to invoke the "conscience clause" in order to exclude their children from par- 
ticipating in certain acts of worship or religious instruction programs in the state schools; more than that, Roman Catholics and Jews were entitled to public funding for their own denominational schools. For all these reasons, Britain might have thought that it had become, in the words of the Anglican Book of Common Prayer, a haven for "all sorts and conditions of men." Instead, as I said, it finds itself with a religious or cultural problem. And, faced with a similar situation, so might we.

The problem arose from the fact that there are now one and a half million Muslims in England alone, a total exceeding the number of Roman Catholics and Jews; and, to say the least, Muslims especially do not believe, because they cannot believe, in the separation of church and state. Bernard Lewis explained why this is so. "Muhammed," he said, "was not only a prophet and a teacher, like the founders of other religions; he was also the head of a polity and of a community, a ruler and a soldier." ${ }^{15}$ It was this (and "a thousand other reasons") that led Tocqueville to say that Islam and democracy could not readily coexist. ${ }^{16}$ The Salman Rushdie affair made the British very much aware of this; they learned, as we might come to learn, that Muslims do not believe in freedom of speech, for example. ${ }^{17}$

Freedom of speech is not the only problem for Muslims (to the extent they remain committed Muslims). The other is secularism; and Britain, having embarked on the path of toleration in 1689 , has reached the point where it has become a secular society. In response to complaints made by various minority groups - not, we are told, only the Muslims - - the British government decided to "celebrate diversity" by instituting a program of multicultural religious instruction in the state schools. Under the new program, all religions were, nominally at least, to be "taught"; in fact, however, each was to be taught as a "possible system of meaning and value," or, in the words of the Swann Report recommending the program, taught insofar as its doctrines were not in conflict with "rationally-shared values." Reasonably enough, the Muslims objected to the program (as well as to other elements of the curriculum: anthropomorphic art, sensual music, "progressive" sex education, and the Darwinian theory of evolution). They continue to cling to their "cultural identity" by taking their religion seriously, unlike the British majority. Because they do, they prefer the old system, under which the state schools taught Christian doctrine (or a watered-down version of Christian doctrine) but allowed Muslims to remove their children from the program by invoking the "conscience clause" on their behalf. As they see it, better a "benign uniformity," as one commentator put it, than a "compulsory 'diversity."' At least 
under the old system they were not compelled to subscribe to opinions contrary to their articles of religion.

As one writer suggested, the problem might be resolved by providing public funding of denominational schools without exception:

British Muslims, and for that matter British Hindus, Sikhs, and even its conservative Protestants continue to be denied the denominational status that their numbers and popularity demand. They resent this. They point out, correctly enough, that they pay taxes like everyone else, and should accordingly be granted the same privilege as any other religious minority. They conclude, reasonably enough, that they are denied those privileges because the central authorities fear that, if granted them, they might actually use them for something other than the pursuit of "rationally-shared values." ${ }^{3}$

Rather than accommodating its Muslims, Hindus, and Sikhs by providing public funding of denominational schools without exception, the British majority insists on imposing its policy of not taking religion seriously on minorities that do take it seriously. As a result, Britain has a serious cultural problem.

Unlike the British, we confine religion to the private sphere, and there is much to be said for that policy. Moreover, we protect it there. Thus, in 1925 the Supreme Court held that no state may compel students to attend public, rather than private, or parochial, schools. ${ }^{19}$ As Jefferson once said, "Our civil rights have no dependence on our religious opinions, any more than our opinions in physics or geometry." ${ }^{20}$

Still, contrary to Madison's expectations, the religious problem abides. Try as we might, there are certain to be times in the life of a nation, even a nation devoted to business and its regulation, when men's religious opinions will carry more political weight than their opinions in physics or geometry-or, as the abortion issue should remind us, than their opinions in genetics, ontology, sociology, or whatever. Of course, Madison would have said that abortion did not belong on the national political agenda, and that it was only because of the Supreme Court's improper intervention that it was put there. On the whole, however, our policy of separating church and state has served us well, which is why it is important to understand what it requires of us.

Separation of society and state; separation of the private and the public; separation of church and state-these distinctions are major stones in the foun- 
dation on which American constitutionalism is built, and all of them rest on the constitutional distinction between soul and body. If not the first to make these distinctions, John Locke was the first to persuade Americans of their necessity in politics; and, in his (Virginia) Bill for Religious Freedom, Jefferson was the first to propose that the last of them be embodied in legislation. He had made a careful study of Locke's Letter on Toleration, and in so many words repeated Locke's statements concerning the care of body and soul respectively. According to Locke, the commonwealth is "a society of men constituted only for the procuring, preserving, and advancing . . . life, liberty, health, and indolency of body; and the possession of outward things, such as money, lands, houses, furniture, and the like"; whereas the care "of each man's soul belongs to himself." 21 Or, in Jefferson's words, "the operations of the mind, [as opposed to] the acts of the body, are [not] subject to the coercion of the laws." 22 Accordingly, the framers of the Constitution separated church and state, thereby making religion a wholly private matter.

Keeping it private is another matter. As I have pointed out in another place, ${ }^{23}$ because the biblical religions especially-Judaism, Christianity, and Islam alike-teach that souls belong to God and that, whether through the agency of Moses, Jesus, or the Archangel Gabriel (or Jibral), God has revealed His will or His law respecting the care of souls, there is always the possibility (if not a clear and present danger) that someone, someone not attached to our constitutional principles, will claim to know God's will and try to enforce it on his neighbors. Indeed, as we are reminded almost daily by the events in Algeria, Iran, Iraq, Nagorno-Karabakh, Tajikistan, India, Israel, and what used to be known as Yugoslavia, to say nothing of Northern Ireland, there are people who, when given the chance, will do just that. Such people prefer to fight religious wars rather than accept cultural pluralism; as such, they cannot be "attached to the principles of the government of the United States," and, to recall Madison's words, they cannot readily be incorporated "into our society."

We cannot tolerate them (at least, not in any numbers) because they are not tolerant; more precisely, we must insist that they disclaim the authority on the basis of which one might be intolerant. ${ }^{24}$ This means that, in their capacity as citizens, they must recognize the right of liberty of conscience. For example, just as the Constitution expects us to forget that we were English (Irish, German, or whatever), it expects Episcopalians, for example, to forget the eighteenth of their thirty-nine Articles of Religion, which reads: "They also are to be [held] accursed that presume to say, that every man shall 
be saved by the Law or Sect which he professeth, [so long as] he be diligent to frame his life according to that Law, and the light of Nature." In their capacity as citizens, however, Episcopalians are required to be guided by that light of nature. They are expected to follow the example of a Reverend Mr. Shute in the Massachusetts Ratifying Convention of 30 January 1788: "Far from limiting my charity and confidence to men of my own denomination in religion, I suppose, sir, that there are worthy characters among men of every denomination-among the Quakers, the Baptists, the Church of England; and even among those who have no other guide, in the way to virtue and heaven, than the dictates of natural religion." ${ }^{25}$

In the light of nature (and according to the Constitution), nobody is "accursed." On the contrary, by nature everybody is endowed with the unalienable right to pursue happiness as he (and not his neighbor or the government) defines it. ${ }^{26}$ As Locke put it, liberty of conscience is “every man's natural right," a principle echoed by Jefferson in the (Virginia) Bill for Religious Freedom, where we read that "the rights [of conscience] hereby asserted are of the natural rights of mankind." That principle is embodied in the Constitution - in fact, our constitutionalism rests on it - and we are all expected to acknowledge it when we act politically. The Constitution speaks not of Christian, Jew, or Muslim, but consistently only of undifferentiated "persons" (and, in one place, of "Indians, not taxed"). By so speaking, it seeks to discourage religious (and antireligious) parties in favor of secular political parties. It expects us - whatever our religion, and whatever our cultural "identity" - to be able to come together in those parties. But it is not easy to form a governing political majority with those whom, by their failure to subscribe to our particular articles of religion, we hold to be "accursed."

Thus, contrary to the multiculturalists, the Constitution is not ideologically neutral. If it were, all political issues would be properly resolved, one way or the other, by popular vote of the people or their elected representatives. Among these issues is, or was, the one that engaged Senator Stephen A. Douglas and Abraham Lincoln in the 1850s: the issue of slavery in the territories. Douglas called his slavery policy "popular sovereignty" and made it, thus dignified, the principle of his Kansas-Nebraska Act. But Lincoln insisted that the act was un-American precisely because it took no standwhich is to say, because it was neutral —on the question of whether slavery was good or bad. The act's moral neutrality contradicted the self-evident truth that all men are created equal. 
So, too, with respect to religious issues. Of course, the Constitution is neutral with respect to religion, neutral insofar as it forbids any government policy favoring one religion over another; but this means that religious issues, like that of slavery in the territories, are not properly resolved by popular vote of the people or their elected representatives. Were it otherwise, no constitutional principle would stand in the way of a self-styled "moral majority" determined to impose its ways on those it regards as immoral minorities. Our religious pluralism depends not on ideological neutrality but on the continued vitality of the principles we held to be self-evident in 1776 and embodied in the Constitution in 1787-1788, and prominent among these truths is that the care of each man's soul belongs to himself alone. Not every "culture" recognizes these truths; those that do not cannot be regarded as equal to ours. Which is to say, in the light of the Constitution, all men are created equal, but not all "cultures."

As Amy Gutmann points out (as if it needed pointing out), we encounter problems with multiculturalism "once we look into the content of the various valued cultures." She wonders whether we can afford to respect, or "recognize," illiberal cultures or, as she puts it, "those cultures whose attitudes of ethnic or racial superiority ... are antagonistic to other cultures." ${ }^{27}$ She would surely agree that we cannot allow the successors to the Ayatollah Khomeini to send their agents among us to assassinate our "blasphemous" Salman Rushdies. Unlike Iranian law, under our Constitution there is no such thing as blasphemous speech. If, nevertheless, such assassins do appear among us and commence their vocation, and we apprehend them, as we have apparently apprehended the bombers of the World Trade Center, are they entitled to be tried by the sort of jury that sat in the case of El Sayyid A. Nosair, the accused assassin of Rabbi Meir Kahane? Which is to say, a jury prepared to help a group preserve its cultural identity? There are those who say so. Nosair was represented by the redoubtable William M. Kunstler, who demanded a jury of "third world people"; and, having gotten it, he got an acquittal on the murder charge.

The Sixth Amendment to the Constitution provides that in "all criminal prosecutions, the accused shall enjoy the right to a speedy and public trial, by an impartial jury of the State and district wherein the crime shall have been committed." Now black Americans-whether on trial themselves or as the victims of alleged crimes committed by others-have begun to insist that juries cannot be impartial unless they are representative. In response, several 
state legislatures, including Florida's, have proposed laws guaranteeing racially balanced juries. This may be in violation of the Sixth Amendment, which, the Supreme Court said recently, requires "impartial" juries, but does not require, and may even forbid, "representative" juries. ${ }^{28}$

This jury issue is not new; in fact, it is at least nine hundred years old. In 1255, King Henry III ordered the arrest of some ninety-two Jews on charges of ritual murder. On being indicted and sent to London for trial, eighteen of them, "regarding conviction as a foregone conclusion unless they were allowed a mixed jury, refused to put themselves upon the country." This was construed as a confession of guilt, and the eighteen were summarily executed.

The privilege of being tried by a mixed jury-or, in the official language of the time, by a panel de medietate, which, in this case, meant half Jewish, half Christian - was sometimes denied, and, upon Edward I's accession to the throne in 1272, was revoked for a time; but, when honored, it served as some protection for this particular "cultural" community. That protection came to an end on - and surely not by chance-All Saints Day, November 1, 1290, when Edward "issued a decree consigning the Jewry of England to perpetual banishment." ${ }^{29}$ And with the banishment ended this early experiment in multiculturalism.

Then there is the more recent British practice, the one adopted to deal with the multicultural situation in Northern Ireland. (To paraphrase W. S. Gilbert, Northern Ireland is the very model of a modern multiculturalism.) The current problem is a variation of the one the British faced earlier when they governed the whole of Ireland. Not surprisingly, at that time, trial by jury did not function in Ireland as it did in England. Too often, Irish juries simply refused to convict the guilty; even so, we are told, "that most hallowed right of English law, trial by common jury, was preserved even in Ireland" for most of the nineteenth century. Not so in Northern Ireland today. Faced with unacceptable differences in the way Protestant and Catholic defendants were treated, the British Parliament, in 1973, abolished trial by jury for defendants accused of violent crimes. ${ }^{30}$ So much, then, for that "most hallowed right of English law, trial by common jury."

Banishment is one way to deal with a multicultural problem and abolishing trial by jury is another, but neither is permitted to any government of the United States; our Constitution based on the rights of man forbids it. Do we, then, adopt different rules of justice for our different groups? Amy Gutmann says that "recognizing and treating members of some groups as equals now seems to require public institutions to acknowledge rather than ignore 
cultural peculiarities, at least for those people whose self-understanding depends on the vitality of their culture." ${ }^{\prime 11}$ But instead of recognizing their "cultural peculiarities," especially their peculiar or different rules of justice, do we not owe it to ourselves to persuade them of the superiority of ours: trial by impartial jury and the other elements making up due process of law; government by the consent of the governed; freedom of speech, press, and conscience; in a word, government designed to secure the unalienable rights not of groups or "cultures" but of man? Indeed, does not our system of constitutional government itself presuppose one people - in the words of Federalist 2 , a people "attached to the same principles of government"? To pose the jury question bluntly, does not the criminal justice system presuppose that African American, Hispanic American, Asian American, and Jewish American defendants can receive a fair trial by "impartial" juries and judges? And that it will be a sorry day for this country if they cannot?

The jury problem pales almost to insignificance when weighed with the problem facing many liberal democracies today, especially those of Western Europe, that of accommodating the refugees from the east and south. The problem is new, but its seeds were sown in religious conflicts five hundred and more years ago. Speaking in Washington a few years ago, political scientist Samuel P. Huntington said that "the most significant dividing line in Europe may well be the eastern boundary of Western Christianity in the year 1500."

The peoples to the north and west of this line are Protestant or Catholic; they share the common experience of European history; they are generally better off than the peoples to the east. The peoples to the east and south are Orthodox or Muslim; they historically belonged to the Ottoman or tsarist empires; they were only lightly touched by events shaping the rest of Europe. Conflict along the fault line between Western and Islamic civilizations has been a seesaw for 1,300 years, and it is unlikely to cease. ${ }^{32}$

The movement of peoples today-sometimes almost entire populations-illustrates not only the enduring strength of these religious and ethnic hatreds but the extent of the problem facing liberal regimes today. It is sufficient to mention Germany, where the influx of refugees from Eastern Europe has given rise to a resurgence of nationalist sentiments of the nastiest kind; or Italy, which turned back entire shiploads of people fleeing Albania; or France and its treatment of North Africans; or, for that matter, President Clinton's tergiversation respecting Haitian refugees. 
In this situation, it is easy to sympathize with Prime Minister Trudeau's multicultural policy; generous, tolerant, and seemingly liberal, it was supposed to provide an example to a world sorely in need of what it had to offer. It was to make Canada "a special place, and a stronger place," stronger than the United States, a multicultural "mosaic" rather than a "melting pot," "a brilliant prototype for the moulding of tomorrow's civilization." ${ }^{33}$

At his urging, Canada officially became a bilingual country. In order to become the master of its own fate, it arranged to have the British North American Act of 1867 converted into the Canadian constitution, or, in the word at the time, it "patriated" its constitution from Britain. To guarantee the rights of all its people, in whatever province they might reside, in 1982 it attached to that "patriated" constitution a Charter of Rights and Freedoms. Since then the country has been engaged in what might be described as a perpetual and itinerant constitutional debate, moving from Ottawa, to Meech Lake, to Charlottetown, with frequent stops in all the provincial capitals, most frequently and persistently Quebec. At issue was (and is) Canadian unity.

The first Ottawa round-commentators have adopted the parlance of prize fighting to describe this debate-ended when Trudeau's nationbuilding effort, with its emphasis on the equal rights of Canadian citizens at the expense of the powers of the provinces, went down to defeat at the hands of the Quebecois. In round two, the western provinces, reacting to Trudeau's language and energy policies, began to demand a restructuring of the Senate in order to check the power of populous Ontario and Quebec. This was followed by the election of a separatist government, under Rene Levesque, in Quebec. Round three began in 1980 with Trudeau's effort to bypass the provincial governments by appealing to the people directly; but, failing in this, he was forced to make the concessions demanded by the provincial governments in order to get the constitution "patriated"; even so, Quebec refused to go along. Round four engaged the aboriginal peoples who, dissatisfied with a constitutional provision guaranteeing their "existing rights," renewed their demand for self-government; at the same time, Ottawa (now represented by Brian Mulroney) and Quebec (now represented by Robert Bourassa) began a series of negotiations with the various provincial premiers, leading to the Meech Lake Accord of April 30, 1987. Under this agreement, all the provinces would gain the powers demanded by Quebec, although Quebec was to be recognized as a 
"distinct society." Under its terms, the accord had to be ratified by the federal parliament and all ten provincial legislatures. This requirement proved to be its undoing because by involving the legislatures it involved the people, if only indirectly; and, as the public opinion polls indicated, a majority of the people were strongly opposed to it. Round five came to an end in October 1992, when a majority of Canadians, in a majority of provinces, and in a national referendum, rejected the Charlottetown Accord. It was rejected largely because, in order to win equal representation in the Senate, the polygenetic western provinces had to agree to allow largely French Quebec, regardless of the size of its population, to have 25 percent of the seats in the House of Commons. One commentator described the process as "a deal-maker but a referendum-breaker." ${ }^{34}$ Then, in October 1995, a proposal to make Quebec a sovereign nation was defeated 49.4 to 50.6 percent in a popular referendum. The leader of the separatist Bloc Quebecois, Lucien Bouchard, said that "the next time will be the right time, and the next time may come sooner than people think."

From this brief account it is possible to draw several conclusions bearing on multiculturalism: the effort to accord recognition and its attendant privileges to one group, cultural or otherwise, will provoke either similar demands from other groups or, especially when the people are brought into the process, a stubborn refusal to make the accommodation. The "Ukrainians" of Manitoba are less likely than their political leaders (at least those at Meech Lake) to indulge the "French" of Quebec. Like other "peoples," especially in a regime that recognizes "peoples," they have pride too. Thus, although the Meech Lake politicians saw the proposed constitutional recognition of Quebec's "distinct society" as merely symbolic and understood that what really mattered was the extent of the powers granted to the provinces, the "people" stamped their feet and said no.

Comparisons with the United States are surely unfair to Canadians; but, if we would avoid its problems, comparison with Canada can be useful to us. Canada began as two societies and remained two largely separated societies for the better part of its history; and its efforts to build one multicultural society have ended, for the time at least, with a country more divided than ever. Whereas, if (but only for the time being) we ignore the blackwhite division (which was resolved, to the extent that it was resolved, only by a civil war), America began as one people; and its policy of assimilating, rather than accommodating, its immigrants has allowed it (for the time, at 
least) to remain one. It was able to assimilate them because it was able to persuade them that its ways, its rules of justice, and its religious principles were superior to those they may have brought with them.

"All eyes are open, or opening, to the rights of man. The general spread of the light of science has already laid open to every view the palpable truth, that the mass of mankind has not been born with saddles on their backs, nor a favored few booted and spurred, ready to ride them legitimately, by the grace of God." So wrote Jefferson in the last of his many letters. ${ }^{35}$ But too many eyes are closed, or closing, today. Today that abstract or palpable truth is too often seen as mere opinion, one opinion among many, and all of them equal; and if our multiculturalists have their way-and if all cultures are equal, why should they not have their way?- - all of them are to be taught in the public schools. The idea of the rights of man will occupy no special place in such a curriculum. As one of many ideas, its authority is almost certain to be weakened, and with its weakening will come a weakening of the foundation on which we have built the pluralism - and the liberty — we have enjoyed from the beginning.

It is especially likely to be weakened when the loudest voices we hear today are contemptuous of the world built by Jefferson and his colleagues. His invocation of "the light of science" is seen by some as part of a plot, a way of justifying the continued hegemony of his kind, namely, white European males and their white American male coconspirators.

This contempt for things American-at its base a self-contempt-is nowhere better expressed than in the 1993 Bienniel Exhibition of American Art at New York's Whitney Museum. Intended to portray the "victims" of American civilization, the show (described in the catalogue as a "multicultural" exhibition) features videos and photographs of black gang members, Mexican hookers, battered women, transvestites; female self-portraits with dildos and prosthetic breasts; "installations" displaying a splat of simulated vomit; and, at the end, in cut-out letters two feet high, the statement "In the rich man's house the only place to spit is in his face." As evidence of their having paid the admissions fee, and by order of the museum's director (rich white David Ross), visitors are required to display a button bearing the words "I can't imagine ever wanting to be white." 36

Leo Strauss had something like this Whitney exhibition in mind when, twenty-nine years ago, he wrote that every such accusation presupposes a law-in this case (so severe are the Whitney accusations) something like a holy law-against which political life is to be measured. ${ }^{37}$ One might think 
that life in the United States could be heaven, or was supposed to be heaven; but the founders promised no such thing. What they promised was liberty, including the liberty to tend to the salvation of our own souls; and the country they established was the first in all of history to make, and to keep, that promise. By keeping it-here I quote Werner J. Dannhauser-they made "corruption voluntary to an appreciable degree." 38

The proponents of multiculturalism fail to appreciate what has been accomplished in and by the United States, and their project, when taken seriously, would have the effect-and, in the case of the Whitney people, the intended effect - of undermining its foundation. The future of constitutionalism depends, in part, on our ability to understand this.

\section{Notes}

1. For an account of the attempt to define culture, see Raymond Williams, Culture and Society (New York: Columbia University Press, 1958).

2. Allan Bloom, "Commerce and Culture," in Giants and Dwarfs (New York: Simon \& Schuster, 1990), 280.

3. Amy Gutmann, "Introduction," Multiculturalism and "The Politics of Recognition": An Essay by Charles Taylor, with Commentary by Amy Gutmann, Steven C. Rockefeller, Michael Walzer, and Susan Wolf, ed. Amy Gutmann (Princeton: Princeton University Press, 1992), 3.

4. H. D. Forbes, "Multiculturalism: The General Principles in the Canadian Case" (paper prepared for delivery at the 1990 Annual Meeting of the American Political Science Association), 2.

5. Forbes, 16.

6. A news item of some years ago illustrates the problem: "Gojko Susak, the Croatian defense minister who three years ago was running a chain of pizza parlors in Ottawa, Canada, says the U.N. complaints about Croatian deception are 'their excuse for not doing what they are supposed to do.' In his Zagreb office, where a bear skin rug that once belonged to former Yugoslavian strongman Josip Broz Tito covers the floor, Mr. Susak [insists] that the Croats have stopped [the Serbian] offensive." Wall Street Journal, 8 March 1993, A6.

7. In this connection, it is interesting to note that "pluralism" as a political term is a neologism, one that made its first appearance in the Oxford English Dictionary only with the publication of the Supplement in 1982. There we are told that "pluralism," meaning "the existence or toleration of diversity of ethnic groups within a society or state, of beliefs or attitudes within a body or institution, etc." was first used in 1956 by Horace Kallen in his book Cultural Pluralism and the American Idea. Rogers Smith informs me, correctly, that Kallen used the term "cultural pluralism" in 1924 in his Culture and Democracy. 
8. Annals of Congress, vol. 1 (Feb. 3, 1790), 1150; vol. 3 (Dec. 22, 1794), 1008.

9. Thomas Jefferson, Notes on the State of Virginia, Query VIII, in Jefferson, Writings (New York: The Library of America, 1984), 211.

10. Jefferson, Notes, 212.

11. Goodwin Watson, in Horace Kallen, Cultural Pluralism and the American Idea (Philadelphia: University of Pennsylvania Press, 1956), 166.

12. Communist Party of Indiana v. Whitcomb, 414 U.S. 441 (1974).

13. Davis v. Beason, 133 U.S. 334 (1890), 341-42.

14. United States v. Macintosh, 283 U.S. 605 (1931), 625.

15. Bernard Lewis, 19th Jefferson Lecture (Washington, D.C., May 1990).

16. Alexis de Tocqueville, Democracy in America, vol. 2 (New York: Vintage Books, 1990), book 1, ch. 5, p. 23.

17. The Ayatollah Khomeini ordered Rushdie to be assassinated for publishing what Khomeini said was a blasphemous book, Satanic Verses.

18. S. J. D. Green, "Religion and the Limits of Pluralism in Contemporary Britain," Antioch Review 49, no. 4 (Fall 1991): 581. I am indebted to this article for my account of the British situation.

19. Pierce v. Society of Sisters, 268 U.S. 510 (1925).

20. Thomas Jefferson, A Bill for Establishing Religious Freedom, in Writings, 346.

21. John Locke, A Letter Concerning Toleration (Indianapolis: The Library of Liberal Arts, 1955), paragraphs 6-7, 36, pp. 17, 30.

22. Jefferson, Notes, Query XVII, in Writings, 285.

23. See Walter Berns, Taking the Constitution Seriously (New York: Simon \& Schuster, 1987; paperback ed., Madison Books, 1992), 162.

24. The difference between a policy of toleration and the American policy was well stated by George Washington in his famous letter of August 17, 1790, to the Hebrew Congregation of Newport, Rhode Island: "It is now no more that toleration is spoken of as if it were the indulgence of one class of people that another enjoyed the exercise of their inherent natural rights, for, happily, the Government of the United States, which gives to bigotry no sanction, to persecution no assistance, requires only that they who live under its protection should demean themselves as good citizens in giving it on all occasions their effectual support....

"May the children of the stock of Abraham who dwell in this land continue to merit and enjoy the good will of the other inhabitants-while every one shall sit in safety under his own vine and fig tree and there shall be none to make him afraid." The Writings of George Washington, vol. 31, ed. John C. Fitzpatrick (Washington, D.C.: Government Printing Office, 1939), 93n.

25. Jonathan Elliot, ed., The Debates in the Several State Conventions on the Adoption of the Federal Constitution, vol. 2 (New York: Burt Franklin, n.d.), 118. The article being debated was the Article VI provision forbidding religious tests for office holders.

26. "The legitimate powers of government extend to such acts only as are injurious to 
others. But it does me no injury for my neighbor to say there are twenty gods, or no god. It neither picks my pocket nor breaks my leg." Jefferson, Notes, Query XVII, in Writings, 285.

27. Gutmann, 5 .

28. See Holland v. Illinois, 493 U.S. 474 (1990).

29. Selden Society, Select Pleas, Starrs, and Other Records from the Rolls of the Exchequer of the Jews, ed. J. M. Rigg (London: Bernard Quaritch, 1902), xxi, xl-xlii.

30. Kevin Boyle, Tom Hadden, and Paddy Hillyard, Law and State: The Case of Northern Ireland (London: Martin Robertson; Amherst: University of Massachusetts Press, 1975), 95-96, 174-75.

31. Gutmann, 5.

32. For an expanded version of Huntington's lecture, see his essay "Political Conflict after the Cold War," in History and the Idea of Progress, ed. Arthur M. Melzer, Jerry Weinberger, and M. Richard Zinman (Ithaca: Cornell University Press, 1995), 137-54.

33. Pierre Elliott Trudeau, Federalism and the French Canadians (Toronto: Macmillan, 1968), 178-79. As printed in Forbes, 16.

34. Peter H. Russell, "The End of Mega Constitutional Politics in Canada?" PS (March 1993), 33. I am indebted to Professor Russell for much of the above account.

35. Thomas Jefferson to Roger C. Weightman, June 24, 1826, in Writings, 1517.

36. Washington Post, 4 March 1993, C1, C4; Wall Street Journal, 5 March 1993, A7.

37. Leo Strauss, Liberalism: Ancient and Modern (New York: Basic Books, Inc., 1968), 262.

38. Werner J. Dannhauser, "Ancients, Moderns and Canadians," Denver Quarterly 4 (1969): 97. 


\title{
Chapter 6 \\ Majoritarian Democracy and Cultural Minorities
}

\author{
Bernard Boxill
}

The classic problem of majoritarian democracy is that it enables the majority to tyrannize minorities. This problem is less serious if different majorities tend to form on different issues, for in that case no minority is likely to be a permanent minority. It is more serious in culturally plural societies where one of the cultural groups is an absolute majority. The cultural ties binding the members of such a majority will incline them to stand together on many different issues, to use the principle of majority rule to secure their interests at the expense of the minority cultures, and to impose their values and way of life on them.

Members of the majority culture may claim that they should be free to impose their values and way of life on minorities. To support this claim they may appeal to the dangers of culturally plural societies and to the benefits of culturally homogeneous societies. Culturally plural societies are said to be prone to murderous conflict, and culturally homogeneous societies are said to contribute to community, fraternity, and a sense of belonging. But even if these claims are true, a cultural majority may act wrongly in imposing its values and way of life on cultural minorities. People may have rights to retain their culture and to pass it on to their children, which forbid their forcible acculturation, even if that would make the society culturally homogeneous and a better society.

Democracies have standardly tried to solve the problem of the tyranny of the majority by enshrining certain rights in a constitution that can be changed only by an overwhelming majority. This device can be applied to the particular problem of a majority culture trying to impose its values and way of life on minorities. But it is not altogether satisfactory. For one thing, even rights enshrined in a constitution can be revoked if the majority that wants them revoked is large and determined enough. More importantly, the 
device only forces the majority to tolerate minorities. It may prevent a majority from violating minorities' most basic interests, but it need not give minorities opportunity to flourish or to contribute to the society. In this essay I develop this objection to majoritarian democracy and suggest briefly one possible solution to the problem it points to.

I begin with the argument that the usual rights enshrined in the Constitution for the protection of minorities need not give them an opportunity to flourish. My argument is based on an argument proposed by Mill in Representative Government. In that book Mill argued that "true" democracy required provisions to ensure that minorities were represented in the legislative body. Since the usual systems of majoritarian rule keep minorities out of the legislative body, Mill called them "false" democracy and argued that their "inevitable consequence" was the "complete disfranchisement of minorities" even if they had the vote. ${ }^{1}$ Mill's conclusion is too strong. Although he was right that the usual systems of majoritarian rule do not ensure that minorities are represented in legislative bodies, he was wrong to conclude that they lead to the disfranchisement of minorities. People are not disfranchised because their favorite candidate for office is not elected, they are disfranchised when their right to vote is violated; but the usual systems of majoritarian rule guarantee minorities the right to vote. Still, there is something to Mill's complaint about majoritarian democracy. Part of this, I argue, is that majoritarian democracy may not give cultural minorities an equal opportunity to flourish.

I assume that Mill's claim about majoritarian democracy and minorities in general implies a similar claim about majoritarian democracy and cultural minorities. That claim, that majoritarian democracy keeps members of cultural minorities out of legislative bodies, is the main premise of my argument. It does not imply by itself that majoritarian democracies do not give people of minority cultures an equal opportunity to flourish; arguably, to flourish in such democracies people must be represented by politicians who pass legislation to help them flourish, and such politicians may be drawn from the majority culture. My argument therefore appeals to two further considerations: first, that, given the usual assumptions of majoritarian democracy, politicians will normally be reluctant to pass legislation specifically to enable people of minority cultures to advance; second, that politicians who care about such people's interests and understand the kind of legislation necessary to enable them to thrive will probably share their culture. 
Despite some utopian thinkers, it may not be possible to design policies that enable all cultural groups to advance and to do so at the same rate. In particular, legislation that enables people of minority cultures to advance may very well slow the advance of those of the majority culture. Further, because human beings usually seem to want to have others to feel superior to, people of the majority culture often feel threatened by legislation that would only enable people of minority cultures to gain on them. Since voters do not support politicians who introduce legislation they see as threatening and politicians want voters' support, politicians usually do not even discuss legislation that would obviously enable people of minority cultures to advance.

It is an invidious assumption that people from the majority culture cannot care about the interests of those in minority cultures and cannot possibly understand and devise the kind of legislation that would enable them to thrive. But two considerations suggest that, all else equal, people of minority cultures are more likely to be well represented by those who share their culture than by others. First, people who share their culture are more likely to identify with them, and consequently to love and care for them, than are outsiders. Supposing that this is usually the case, politicians from a minority culture are likely to be more strongly motivated to design and pass legislation aimed at helping their cultural group advance than are politicians from the majority culture.

The second argument that people of minority cultures are better represented by those who share their culture than by outsiders is that people who share their culture are likely to better understand their culture than outsiders, and consequently likely to better understand what legislation will help them to thrive. This may seem false on the ground that an outsider, standing outside a culture, may better understand a culture's strengths and weaknesses than does a cultural insider. I grant that one must be able to stand outside a culture in order to appreciate its strengths and weaknesses. But politicians from the minority culture will often be able to stand outside their own culture, because they live in a society dominated by the majority culture and are therefore often compelled to step outside their own culture and to operate in the majority culture. Consequently, they will be able to gain the perspective necessary to assessing its strengths and weaknesses. Assuming that they are likely to be among their culture's more mobile and energetic members, they will be especially able to have an informed outsider's view of it, although most members of the culture will enjoy this advantage to some degree. Further, standing outside a culture enables one to appreciate its strengths and weak- 
nesses only if one knows the culture intimately. But politicians from the majority are not likely to know the minority culture intimately. Their culture dominates the society and they do not need to know much about minority cultures. Consequently, unlike politicians from minority cultures, they are unlikely to have an informed outsider's view of minority cultures.

It may be objected that minority cultures do not have to be represented by people who understand their peculiarities and who care about them specifically. I will be reminded of the Japanese and Jews, who have done remarkably well in the United States although they are usually represented by Caucasians and Christians who neither understand them nor particularly care for them. These cases, and others that could be cited, show that it is not a necessary condition that a cultural minority be represented by its members, or even those who understand and care about it, in order to thrive. The cultural minority may feel itself invisible or may believe that the majority will not take the trouble to devise legislation detrimental to it; or it may have qualities that enable it to advance, given the legislation that the politicians elected by the majority pass, even if this legislation is not passed in order to enable it to advance. Considerations such as these probably account for the success of the Japanese and Jews, though it is arguable that the Japanese might have avoided some disasters-I have in mind their internment during the Second World War-if they had not kept such a low political profile. But we cannot generalize from these exceptional cases and conclude that cultural minorities ordinarily do not need to represent themselves politically in order to flourish. In many cases a cultural minority's qualities will not enable it to advance given the legislation that the politicians elected by the majority pass. Normally, to thrive it must be represented by those who understand and care about it, and usually such people will come from its own ranks. This is the basic point about political life that the American revolutionaries learned, and that justified their separation from Great Britain; and it explains why cultural groups invariably seek political representation and power as soon as they become too numerous or too successful to be invisible.

My argument that the usual apparatus of democratic procedures need not give minority cultures opportunity to thrive assumes that members of minority cultures will not be elected to office. This is a reasonable assumption, given the principle of majoritarian democracy that the candidate elected to office gets the most votes and that people tend to vote for candidates from their own cultural group. But it is not always true. A cultural group can constitute a majority in several voting districts even if it is a small minority in 
the country as a whole. In these districts it will probably be represented by those who share its culture, precisely because people tend to vote for candidates of their own cultural groups, and the candidates elected to office are those who get the most votes.

Such representation is better than no representation. It gives the minority culture some measure of self-government and ensures that its representatives have an opportunity to urge policies for its advancement in legislatures made up of representatives of many voting districts, even if the policies they urge are unlikely to be adopted, given that the principle of majority rule holds in the legislature as well as in the competition for office. Nevertheless, requiring cultural groups to segregate themselves in particular voting districts in order to make themselves majorities in those districts has unacceptable consequences. The segregation involved is not likely to be only the innocent result of likeminded people freely choosing to live together. It will probably also require coercion. In order to remain, or to become, a majority in a voting district, a cultural group may have to prevent those of different cultures from moving into the district, or even compel them to leave if they are already there. Since this is unjust and likely to lead to conflict between cultural groups, representation achieved by cultural segregation probably comes at too high a price.

I now take up the argument that majoritarian democracies also fail to give people of minority cultures an equal opportunity to contribute to their societies by taking part directly in legislation. This does not mean, of course, that majoritarian democracies altogether prevent members of cultural minorities from contributing to their societies. There are ways to contribute to one's society besides being elected to office.

The argument that majoritarian democracies do not give members of minority cultures an equal opportunity to contribute directly to the legislation of their society is in a sense a trivial implication of the fact, already established, that majoritarian democracies give members of minority cultures little opportunity to be elected to office. But members of cultural minorities who are excluded from political office by the mechanisms of majoritarian democracy are not likely to feel that their exclusion is trivial. Elected officials design and pass legislation and consequently are able to contribute to their societies in peculiarly powerful and effective ways.

I also want to make the stronger point that members of minority cultures may have something to contribute to legislation in their society that members of the majority culture may not be able to contribute. It relies on 
the kind of considerations that John Stuart Mill used to justify his claim that society should value freethinkers, eccentrics, and intellectuals. Mill did not simply urge mechanisms and policies-like systems of entrenched rightsthat would help to prevent the majority from overwhelming freethinkers, eccentrics, and intellectuals. More generally, he did not want the majority only to tolerate these minorities. He believed that it should value them because they could have something to teach it. His best-known argument is stated in On Liberty. In that work Mill maintains that unless people harm others they should be allowed to live as they decide. Some of his arguments for this claim justify only toleration. I have in mind where he argues that a person's "own mode of laying out his existence is best, not because it is best in itself, but because it is his own mode." ${ }^{2}$ But other arguments stress that allowing others to live as they please can contribute to the discovery of ways to live that are objectively best. This is the well-known "experiments in living" argument. Mill's idea was that people who try unconventional ways of living may well hit on practices that the majority can learn from and adopt to its benefit. As he wrote, "It is important to give the freest scope possible to uncustomary things, in order that it may in time appear which of these are fit to be converted into customs." ${ }^{3}$

If Mill's argument is sound, valuable and useful ideas about how to live probably derive from all cultures, and consequently from minority cultures. I believe this to be the case because cultures are experiments in living.

People do not normally think of their own culture as an experiment in living. They do not suppose that their culture's mores and practices are hypotheses about how life should be lived and that in following these mores and practices they are behaving somewhat like scientists subjecting hypotheses to empirical tests. Normally they act as their culture dictates because they don't think about it, or because they believe that alternatives are wrong, or sometimes because they cannot conceive of alternatives. Still a culture is an experiment in living in the sense that things happen as a result of people following its mores and practices, and people do learn from how and why these things happen. This is why cultures change. People see what the consequences of living according to the mores and practices of their culture are, and as a result some of the more sensitive or imaginative or daring among them are moved from time to time to do things differently themselves or to urge their fellows to do things differently. When their example is followed, or their suggestions are accepted-and only rarely does either happen quickly - their culture slowly changes. 
I say "changes" advisedly, and not "improves." An enterprising knave may hit on a way to circumvent an important cultural convention for his personal advantage. If others follow his example, the overall result could be retrogression. Of course, in time people will learn from that "experiment," and some of them may introduce reforms, though again we cannot conclude that these reforms will be altogether successful or that they will not have unforeseen and undesirable side effects. Still, if Mill is right that a majority may stand to learn from the experiments in living of freethinkers and eccentrics, it probably stands to learn much more from the experiments in living of minority cultures. The experiments in living of freethinkers and eccentrics are usually conducted on a small scale and for a short time. This should make a large society that wants to reproduce itself extremely wary of taking them seriously, however attractive they may seem. A culture, on the other hand, is always the result of an exceedingly long series of related experiments in living in which each experiment is designed in the light of what was learned in earlier experiments. More than that, it is also partly a series of interrelated reflections on the series of experiments in living. People do not only learn from their mores and practices; they also reflect on what they have learned, on the possibilities and impossibilities it reveals to them, and consequently on what they can and cannot reasonably hope to achieve. Each of these reflections is made in the light of previous reflections and influences the direction the series of experiments in living takes. As a result the experiments in living of a culture become an attempt to work out a point of view of how to live, and every culture contains a commentary on the difficulties and possibilities of working out that point of view. Now it is highly unlikely that every culture has the same point of view on how to live and the same commentary on the difficulties and possibilities of working it out. The protean nature of human inventiveness and the variety of circumstances in which cultures evolve ensure this. Assuming that the majority has not discovered all there is to know about how to live, and that minorities have not gotten it all wrong, I conclude that minority cultures may well contain moral and political ideas that would help legislatures make better laws if they were presented there.

The main conclusion of the preceding sections is that the classic problem of majoritarian democracy, the "tyranny of the majority," is likely to be especially pertinent and costly in culturally plural societies where one of the cultural groups is an absolute majority. In such societies, majoritarian 
democracy denies cultural minorities opportunities to flourish and to contribute directly to legislation. Since people feel alienated from their societies when they are denied such opportunities, it is hardly surprising that the standard democratic apparatus of measures and provisions often fails to foster a sense of community and belonging in culturally plural societies.

This suggests that culturally plural societies should begin to consider seriously alternatives to the standard procedures of majoritarian democracy. One alternative is especially attractive because it has much to recommend it apart from the fact that it seems a promising way to correct the tendency of majoritarian democracy to exclude cultural minorities from public office. This is Thomas Hare's system of the single transferable vote, which Mill hailed as "among the greatest improvements yet made in the theory and practice of governments." Mill was enthusiastic about Hare's system because it ensured that his favorite minorities-freethinkers and intellectuals-would get represented in proportion to their numbers without having to live in any particular part of the country. But it would also ensure that cultural minorities were represented in proportion to their numbers without having to segregate themselves in particular voting districts. ${ }^{5}$ Majoritarians have strongly criticized the single transferable vote system and have questioned Mill's motives for endorsing it. ${ }^{6}$ These criticisms have to be taken seriously. But the single transferable vote system seems a good place to start the search for a way to avoid the weakness of majoritarian democracy in culturally plural societies.

\section{Notes}

1. John Stuart Mill, Utilitarianism, On Liberty and Representative Government (New York: Dutton, 1951), 345.

2. Mill, 167.

3. Mill, 167.

4. Mill, 354.

5. Arthur Lewis made this point when he recommended proportional representation to the culturally plural societies of West Africa. See his Politics in West Africa (New York: Oxford University Press, 1965).

6. See, for example, Paul B. Kern, "Universal Suffrage Without Democracy: Thomas Hare and John Stuart Mill," Review of Politics 34 (1972): 306-22; and Gideon Doron and Richard Kronick, "Single Transferable Vote: An Example of a Perverse Social Choice Function," American Journal of Political Science 21 (1977): 303-11. 


\title{
Chapter 7 \\ Democratic Multiculturalism
}

\author{
Wilson Carey McWilliams
}

Historically, multiculturalism has not often been associated with democracy; more often, it has been the practice of empires and hegemonies, the condition of a policy of divide and rule. 'In fact, multiculturalism is not easily compatible with democracy, as any day's newspaper can tell us: Yugoslavia managed, more or less, as a one-party autocracy, but it proved unable to survive democratization, and it would be easy to add other painful examples.

Nor is this surprising: a grand tradition in political theory holds that democracy requires a high level of trust in one's fellow citizens, or at least a broad sphere of the taken-for-granted in civil life. As in the New England of Tocqueville's describing, an open politics presumes a more or less closed society. ${ }^{2}$

The Federalist's argument for a large and diverse republic, of course, reverses this order of things. It prescribes social openness of a fairly radical sort, making it a first principle to protect the differences in our faculties and opinions. The new order of the American republic, consequently, is not defined by usages and habits, but by forms and laws. ${ }^{3}$ The framers' tolerance did have limits: they assumed and relied on a people who observed the decencies and for whom a word was a bond. At bottom, however, they afforded us a relatively open society on the basis of a politics that is closed in critical respects. The Constitution's constraints and barriers only follow the even stricter teaching of the Declaration of Independence, according to which we are allowed to calculate our interests and to bargain them away, but our rights are unalienable, immune to the discountings of interest or culture. ${ }^{4}$

It is worth remembering that there were serious conflicts of culture in eighteenth-century America, most evident in the problem of slavery-for slavery, as Anne Norton reminds us, did create a culture and a tenacious one-but also simmering in the relations between Europeans and aboriginal peoples, in the conflict between religion and secularism, and in the largely forgotten animosities among sects. ${ }^{5}$ From the beginning, multiculturality has tested the Constitution and the laws, raising the question of 
whether conflicts between cultures can be subordinated to and confined within democratic forms or whether "culture wars" will be fought with weapons other than words and votes. ${ }^{6}$

Slavery, of course, proved too much for democratic politics, and Tocqueville, who feared as much, was also too close to the mark in his pessimism about race. But Tocqueville was impressed by the American entente with religion, especially because the republic seemed on the way to an accommodation with Roman Catholicism; and his argument has a good deal to say about the conditions of successful multiculturality.

Tocqueville observed that any religious doctrine (and he might have added, any culture) has a political tendency that will assert itself if unchecked. Circumstances, however, can alter the effects of belief, its expression in day-to-day life. Thus, despite its aristocratic structure and historic affinities, Roman Catholicism in America had some sympathy for republican government, just as most Catholics supported the Democratic Party, if only because, en masse, American Catholics were poor.?

Confrontation with new circumstances unsettles authority and forces a belief or culture to abandon the habitual for the more or less conscious and chosen, separating those things that seem essential - that must be remembered and retained-from those that can be safely left behind. ${ }^{8}$ The new world of Tocqueville's discerning, of course, challenges all ways and faiths to accommodate themselves to democratic principles. Prudence dictates that the majority not be opposed except in vital matters, and even then, with the foreknowledge that defeat is likely: "In ages of equality, kings may often command obedience, but the majority always commands belief." That counsel is even more urgent in a country like the United States, where democracy has shaped the laws. Religions and cultures are fortunate, consequently, if their tenets are at least compatible with democratic doctrine. Without that consonance, they face political society on an implicit field of battle; and even those, like Tocqueville, who are confident that they can predict the winner may regret the war.

In Tocqueville's view, Catholics were among the lucky, because America imposed only a kind of purification on a faith already egalitarian at root. As Tocqueville explained it, amid the unequal societies of the feudal era, responding to a world of nations, castes, and classes, the Church - while clinging to the universal sovereignty of God-had "improperly enhanced" the importance of "divine agents." ${ }^{10}$ America, Tocqueville claimed, had allowed and compelled the Church to return to first things, and especially to an emphasis on 
human unity. (By contrast, Tocqueville thought that any relation between democracy and Islam would be more troubled, because so much traditional legal and political teaching is included in the Koran, at the heart of the creed; and there is very little, so far, to suggest that he was not right.)"

Moreover, among Catholics, American laws were nurturing new political beliefs. Catholics had accepted a religiously neutral government partly from necessity and partly to protect themselves against old animosities, but Tocqueville found them increasingly positive in their support for a separation of church and state. Even the zealous Father Mullon told Tocqueville and Beaumont that state support for religion was harmful; and startlingly, the vicar general claimed that "enlightenment" was favorable to the "religious spirit." ${ }^{2}$

As Catholicism was "modified" in a democratic and republican direction, Tocqueville contended, there was a reciprocal growth of tolerance between Catholics and non-Catholics, a softening of the boundaries between communions. Not that Catholicism had dissolved into indistinction: its rites and beliefs still seemed bizarre to the Protestant majority. But, as Tocqueville saw it, the Church was winning a respected place in American life, with more promise for the future. ${ }^{13}$

Uncharacteristically, Tocqueville was overoptimistic: memories of the Reformation remained a fault line in American party politics at least until 1960, along with the even more tenacious legacy of slavery and the Civil War. ${ }^{14}$ Yet partisan conflicts, as George Washington Plunkitt reminded us, mark democracy's ascendancy over cultures; and in the long term, Tocqueville seems to have been right in thinking that he had discerned a success story in the American politics of culture. ${ }^{15}$

What his argument shows us, however, is stern as well as sunny. Economic and social circumstances, especially well-being, can combine with cultural compatibility to make matters much less painful; but in the end, democracy can accommodate a culture only to the extent that it accepts the sovereignty of democratic laws, and hence the certainty of at least some cultural attenuation. In America, all cultures and faiths-the established as well as the excluded-are caught up in an ongoing redefinition in relation to the laws and to each other, a process of learning, forgetting, and selectively remembering that lays down both the boundaries of community and the civil meaning of the term "American."'

Since, as a general rule, the Constitution insists on an individual's right to leave faith or community behind, the hold of such cultures depends on persuasion and social sanctions, and especially on an early education capa- 
ble of armoring the soul against the power of majority opinion. In critical respects, consequently, a multicultural politics is always a politics of schooling. As institutions, the schools are a proving ground, for there, if not before, the public can make itself heard. (These days, of course, the media inserts its "hidden curriculum" much earlier and more pervasively. ${ }^{17}$ In the dialogue between the public and the cultures, an element of multiculturalism is only good manners, an acknowledgement of one's audience that schools commonly have tried to practice. But contemporary multiculturalism goes farther: up to a point, it seeks to enlist public authority on the side of the cultures - though not, significantly, on the side of faith.

For most of its contemporary defenders, multiculturalism is only a means in the service of a generous, democratic end: their real goal is inclusion, the hope of drawing new groups and cultures into a respected place in a strengthened civic life. As multiculturalists observe, there are cracks in some of the old pillars of American civic education. In lean economic times, there are no guarantees of the assurance of work at socially adequate wages that Jefferson saw as the right bower in the game of civic dignity. ${ }^{18}$ And multiculturalists are even more moved by the fact that the economy and the media are fragmenting communities and cultures, muting the second voice of America's grand dialogue in favor of an increasingly radical individualism on one hand and tyranny of the majority on the other.$^{19}$ Multiculturalism, in this view, is an attempt to check disintegration and to promote a political pluralism in the image of Randolph Bourne's celebrated essay, "Trans-National America."20

Notice at the outset, however, that this sort of multiculturalism regards a broadly democratic politics not as one culture among many, but as a superior standard entitled to rule. That assumption is reflected in the common tendency to slide over or suppress the nondemocratic aspects of the cultures being recognized, implicitly rejecting whatever is incompatible with a democratic life and creed. (I will have more to say about this later on.) And, of course, commitment to multiculturalism is ordinarily accompanied by the insistence that racism, sexism, homophobia, and the like are thoroughly unacceptable. Multiculturalism aspires to substitute a salad bowl for the melting pot, but — as the metaphor indicates—it still looks for a politics enclosed by a democratic orthodoxy.

Yet in their thinking about democracy, multiculturalists incline to focus on the social and the cultural, and to slight democratic institutions-a tendency that is especially unfortunate given the close relationship between the Constitution and the very idea of a multicultural republic. In fact, the 
multicultural persuasion is apt to stress the presence of slavery and the absence of women in the Constitution, or to argue that even the proclamation of natural equality in the Declaration of Independence refers only to "men," and implicitly only to white men, and to conclude that the Declaration and the Constitution reflect only the culture and interests of European males in the then-dominant class.

A good deal of this is simply silly. There is ample evidence, for example, that the Declaration's affirmation of equality was understood to refer to all races, and that the accommodation with slavery in the Constitution - made necessary, paradoxically, by the multicultural goal of including the South in the Union-was regarded as a violation of natural right. Consider the exchange in South Carolina, when one legislator asked that stock-in-trade Antifederalist question, "Why was not this Constitution ushered in with a bill of rights?" Charles Cotesworth Pinckney answered that, among other reasons, "Such bills generally begin with declaring that all men are by nature born free. Now, we should make that declaration with very bad grace, when a large part of our property consists in men who are actually born slaves."21

Even where the multiculturalist critique tells us something important about the Constitution, as it does by pointing to oppressions based on race and gender, it underrates the importance of constitutional forms. The norm of equality makes violations of that rule anomalous, things that have to be euphemized or explained. The exceptions are constantly criticized by the rule, which by setting a direction can become, as Harvey Mansfield observes, "the cause of going if not getting there." 2

Democracy, moreover, is a hard school, and the culture of democracy depends on forms, especially in a large republic. Its cornerstone, majority rule, depends on the form by which every vote is treated as equal; similarly, the vast majority of us can have a voice in public councils only through the form of representation, determined in districts and by election. Even our efforts to acquire a more substantial voice through participation require the "art of association," and hence the discipline of Roberts' Rules or some other form of order. ${ }^{23}$ At best, our politics involves frustrations and indignities, and rapid economic change and the resulting disorder of society weaken the compensations of private life. Americans are eager for a kind of strong government, but their support for democratic institutions is dangerously thin..$^{24}$ Multiculturalists, the champions of minorities, have very good reason to give more-and more serious-attention to the institutional frame of American democratic life. 
It is a far more serious problem, however, that democratic multiculturalists are tempted to adopt, as a weapon of convenience against established America, the doctrine of the equality of cultures, forgetting that the enemy of my enemy is not necessarily my friend..$^{25}$ This philosophic multiculturalism holds that cultures are incommensurable, "separate realities" or "stories," so that there can be no ranking of cultures or of the comparative excellence of their parts. And for democratic multiculturalists, that teaching involves at least two towering problems.

In the first place, it disdains cultures themselves, for on their own terms, cultures engage in just this sort of comparison and ranking. When Marc Swartz studied Truk, early in his distinguished career, he expected the islanders to be ethnocentric, proclaiming their ways superior to all others. He found, however, that Trukese often expressed admiration for American technology and deprecated their own crafts. At the same time, the Trukese to whom Swartz talked were shocked by his accounts of family life in America, and especially by the fact that he was not expected, periodically, to work for his brother-in-law, reasoning that their own ways were more likely to unify families (a conclusion that seems tenable, to say the least). The Trukese, in other words, did not see cultures as monads, each locked into the island of its own uniqueness, but as more or less effective answers to human problems. ${ }^{26}$ In the same way, Michael Herzfeld observes that the Cretan villagers he studied understand the world on the basis of a "folk theory," which includes ideas of what it means to be a good man (or to be more exact, to be good at being a man). The superiority of one's self, one's village, or one's nation, in these terms, is inseparable from excellence in fulfilling norms that are asserted as universals. ${ }^{27}$ Even a culture that maintains that "our blood is superior to yours" thinks we can be measured by the same rule. Great cultures instruct and challenge us precisely because they ask, and offer compelling answers to, the questions, "What is human? And what is the best life?" To take cultures seriously is to recognize that such encounters lead to arguments and point toward philosophy, just as diversity is only humanity in masquerade.

Second, a belief in the equality of cultures is at odds with the principle of equality. Plenty of cultures, after all, include a hierarchy of castes or classes or teach a hankering after dominion, to say nothing of racism and sexism. To support democratic equality is to maintain that, in this respect, some creeds and cultures are better and others worse: even the secular spirits among the framers, for example, were inclined to find good words for 
Christianity - whatever their quarrels with it—because of its devotion to egalitarian teaching in the realm of the spirit. ${ }^{28} \mathrm{On}$ its own terms, equality is a ruling standard, entitled to judge the cultures, weighing their customs in the scales of nature.

As I have observed, because most multiculturalists are democrats at bottom, they are tempted or disposed to discount any antidemocratic aspects they meet in a culture. But, the fostering of illusions aside, such "playful multiculturalism" - the term is David Carlin's-loses precisely what is best in a confrontation with a profound and unfamiliar teaching: its capacity to shake our complacency, to force us to articulate first principles, and in general to make us think more seriously about political things. Fuzzing the debate also obscures the likelihood that American citizenship is incompatible with at least some aspects of any ethnic tradition, with the consequence that such citizenship requires that a great deal of any heritage be left behind-a hard truth, but a necessary one for democratic life, and not only in such obvious cases as the Irish and the South Slavs. ${ }^{29} \mathrm{G}$. K. Chesterton put democratic multiculturalism in perspective when, not altogether playfully, he likened the United States to the Spanish Inquisition, because while America is not entitled to exclude per se a Catholic or a Muslim, a Japanese or-pace Pat Buchanan-a Zulu, it has both a right and a duty to reject any challenge to equality as the ruling principle of public life. ${ }^{30}$

And while, unlike the Inquisitors, we are not allowed to burn the heterodox-the self-immolation of the Branch Davidians constrains me to add, at least not on purpose-it is incumbent on us to recognize that the "equality of cultures" is a rival principle, one that asserts its superiority over democracy, which it reduces to one culture among many. In fact, it regards all cultures as decisively inferior to the enlightened perspective that sees them as no more than a kind of entertaining storytelling. In the view of those Carlin calls "grave multiculturalists," the real title to rule rests with nihilists, happy or otherwise, who recognize that true ranking of human understanding. ${ }^{31}$

It is a troubled time for the republic, and we have every reason to draw on what is best in all our cultures and traditions-including, if it needs to be said, voices from the underside and from new or neglected corners of American life. (Among many possibilities, I am thinking of Maxine Hong Kingston's The Woman Warrior and Carlos Bulosan's remarkable America Is from the Heart. ${ }^{32}$ ) But when economic circumstances are not cheering and the compatibility of cultures is imperfect, even more than usual the possi- 
bilities of multicultural democracy depend on the framing strength of the Constitution and the laws. For democratic multiculturalists, no imperative is greater than the need to rebuild the institutions that connect citizens with their government, and with them, a politics guided by the proposition that all human beings are created equal. ${ }^{33}$

\section{Notes}

1. Among modern examples, British India comes to mind, especially because the British so often justified their rule as essential to multicultural peace. Ironically, those who are attracted to the language of "Hegemon" and "Other" tend to pass lightly over these connections between multiculturalism and elite rule, although, as I will be arguing, there is a sense in which it is not ironic after all.

2. Alexis de Tocqueville, Democracy in America, trans. Henry Reeve (New York: Knopf, 1980), 1:43. See also Joshua Miller, The Rise and Fall of Democracy in Early America, 1630-1789 (University Park: Pennsylvania State University Press, 1991), 21-49.

3. Despite anxieties about immigrants, which found expression in the early naturalization laws, the Constitution's requirements for habituation are extremely modest. The debate in the Convention is instructive. See James Madison, Notes of Debates in the Federal Convention of 1787 (Athens: Ohio University Press, 1966), 409-11.

4. Harvey C. Mansfield, Jr., America's Constitutional Soul (Baltimore: Johns Hopkins University Press, 1991), 82.

5. Anne Norton, Alternative America: A Reading of Antebellum Political Culture (Chicago: University of Chicago Press, 1986).

6. Part of the contemporary version of this test is discussed in James D. Hunter, Culture Wars: The Struggle to Define America (New York: Basic Books, 1991).

7. Alexis de Tocqueville, Journey to America, ed. J. P. Mayer (New Haven: Yale University Press, 1962), 150.

8. Tocqueville, Democracy in America, 2:25-26. Tocqueville noticed a tendency among Catholic clergy to emphasize the "spirit" rather than the "letter" of the law. Tocqueville, Democracy in America, 2:27.

9. Tocqueville, Democracy in America, 2:26.

10. Tocqueville, Democracy in America, 2:23-24.

11. Tocqueville, Democracy in America, 2:23. While Christianity includes political teachings, John Hallowell wrote, it "is not itself a political philosophy or an economic program." Main Currents in Modern Political Thought (New York: Holt, Rinehart and Winston, 1950), 692.

12. Tocqueville, Journey to America, 33, 206, 257.

13. Tocqueville, Journey to America, 59-60, 236-37; and Tocqueville, Democracy in America, 2:29-30. 
14. Samuel P. Hays, "Political Parties and the Community-Society Continuum," in The American Party System, ed. William N. Chambers and Walter D. Burnham (New York: Oxford University Press, 1967), 152-81; V. O. Key, "The Future of the Democratic Party," Virginia Quarterly 28 (1952): 161-75; and John H. Schaar and Wilson C. McWilliams, "Uncle Sam Vanishes," New University Thought 1 (1961): 61-68.

15. William Riordon, Plunkitt of Tammany Hall (New York: Dutton, 1963), 13.

16. For example, in 1993, the Ancient Order of Hibernians won the right to exclude Irish gays and lesbians from the St. Patrick's Day parade in New York, arguing that the holiday is distinctively Catholic. Yet only a few Americans remember the conflict of Green and Orange, and to most of those who do, it seems curmudgeonly to wear Protestant colors-as I do-on March 17.

17. Uri Bronfenbrenner, "Contexts of Child Rearing," American Psychologist 34 (1979): 844-50. Of course, communities can create their own schools as supplements to public education or as alternatives to it. But the requirement of accreditation means that public doctrine cannot be altogether excluded.

18. Letter to John Adams, October 28, 1813, in Life and Selected Writings of Jefferson, ed. Adrienne Koch and William Peden (New York: Modern Library, 1944), 633.

19. Robert Bellah et al., Habits of the Heart: Individualism and Commitment in American Life (Berkeley and Los Angeles: University of California Press, 1985).

20. Randolph Bourne, "Trans-National America," Atlantic Monthly 118 (July 1916): 86-97.

21. Cited in Robert M. Weir, "South Carolina: Slavery and the Structure of the Union," in Ratifying the Constitution, ed. Michael Allen Gillespie and Michael Lienesch (Lawrence: University Press of Kansas, 1989), 222.

22. Mansfield, 12.

23. Tocqueville, Democracy in America, 2:102-5, 109-10.

24. See my essay "The Meaning of the Election," in Gerald M. Pomper et al., The Election of 1992 (Chatham: Chatham House, 1993), 194-97.

25. This is an old temptation, to which-as Eric Goldman observed - the American reform tradition is particularly subject. Rendezvous with Destiny (New York: Knopf, 1952). It is, of course, not confined to reformers or to America: "Are you secretly, then," an anguished Demea asks belatedly, "a more dangerous enemy than Cleanthes himself?" David Hume, Dialogues Concerning Natural Religion in Hume: Selections, ed. Charles W. Hendel (New York: Scribner's, 1927), 382.

26. Marc Swartz, "Negative Ethnocentrism," Journal of Conflict Resolution 5 (1961): 79.

27. Michael Herzfeld, The Poetics of Manhood (Princeton: Princeton University Press, 1985).

28. For example, Jefferson's letter to Benjamin Rush, April 21, 1803, in Life and Selected Writings of Jefferson, 566-70.

29. Compare Tocqueville's prescription in Democracy in America, 1:7.

30. G. K. Chesterton, What I Saw in America (London: Hodder and Stoughton, 1922), 7. 
31. David Carlin, "Let Them Eat Cake: A Love Letter to Multiculturalists," Commonweal, 23 April 1993, 9-10.

32. Maxine Hong Kingston, The Woman Warrior (New York: Vintage, 1975); Carlos Bulosan's America Is from the Heart, originally published in 1943, was reprinted by the University of Washington Press in 1973.

33. For some suggestions, see my essay "Tocqueville and Responsible Parties: Individualism, Partisanship and Citizenship in America," in Challenges to Party Government, ed. John K. White and Jerome Mileur (Carbondale: Southern Illinois University Press, 1992), 190-211. 


\title{
Chapter 8 \\ The Virtues of Multiculturalism
}

\author{
Anne Norton
}

If democracy is rule of the people, then we confront, in practice, not democracy but democracies: the rule of different peoples, each people ruling in its own way, each rule bearing the marks of particular pasts, particular conflicts, particular aspirations. We concern ourselves here not with Democracy, but with democracy in America.

When Edmund Burke, the defender of both English tradition and American revolution, looked to the future of America, he foresaw an English nation. "It is the English Constitution, which, infused through the mighty mass, pervades, feeds, unites, invigorates, vivifies every part of the empire, even down to the minutest member." "English privileges have made it all that it is; English privileges alone will make it all that it can be." America would grow, it would change, it might "put the full breast of its youthful exuberance to the mouth of its exhausted parent" but it would remain English, bound not only by adherence to "liberty according to English ideas and on English principles," but also by "the close affection which grows from common names, from kindred blood."

For Burke, peoples were made on the land, in the habits of daily life. They shared a common experience in the flesh, a common ancestry, common roots. History was ancestry. History was a constitution written in the flesh. History was memory. ${ }^{2}$

\section{In America, the English may have ... planted England with a stubborn trust. But the cleft dust was never English dust. ${ }^{3}$}

"The land was ours before we were the land's," as Robert Frost wrote, and we have yet to grow into it. We are ruled not as Burke would have us, by habit and unconscious practice, but by the practiced conviction that change might be for the better and that, therefore, the unexamined life is not worth living. The Americans who bred and taught me, my friends and enemies, 
those I see on television and those I pass on the street, have uncommon names and well-mixed blood. We look not to an English past, but to a various and diverse future.

No people can mistake history for memory in the simplest sense. Little of what we remember as a nation lives in our separate memories. Most of what we take for our history is foreign to our private memories and personal experiences. The second birth into civility that, in Rousseau's words, "from a stupid and unimaginative animal makes an intelligent being and a man" also alters our being in time. ${ }^{4}$ In becoming citizens we acquire a form of being that extends beyond the limits of our separate bodies. Our private memories are supplemented by public and political histories. Insofar as we are citizens, we take those histories for common memory.

For Americans, the taking of history for memory has required that we replace the pious fictions of ancestor-worship with acts of democratic imagination. In order to take history for memory, we have been obliged to turn from the dictatorship of the flesh to a thoughtful election of our pasts.

Most Americans cannot assimilate national histories to the memories of our ancestors. My ancestors, peasants from every backward corner of Europe, did not touch this land until the late nineteenth century. One would have to go nearly back to Adam to find any link between these and Washington, or "Plymouth Rock and all that inbred landlord stock." Yet Washington and Winthrop, Mather and Williams, figure in my histories. These are my people. We are bound together by name, imagination, and desire. I have elected to have a history in common with these, to mark these, foreign to my ancestry in the flesh, as my progenitors.

The opponents of multiculturalism would have me confine my ideal ancestry, my imagined history, to Europe. Why? These alone are not adequate to the constitution of my nationality. My nationality is constituted in the works of W. E. B. Du Bois as well as those of James Madison, in the words of Langston Hughes as well as those of Walt Whitman, in the acts of Osceola as well as those of John Marshall. If I, as an American with no English ancestry, have a past in England, I see no reason why I should not have a past in Africa, a past in Asia.

After all, I do, like my country, have a past in Asia. My father was a naval officer who served two tours of duty in Vietnam. While he was in Vietnam, my family lived in a suburban neighborhood in Orange County. That neighborhood is now called "Little Vietnam." Between those two tours of duty, we lived in Bangkok. I learned the Ramayana, acquired a taste for mangoes and 
unripe coconut, and saw the workings of imperialism at school and on the streets. Like my country, I have a past in Asia.

What Hannah Arendt called "the Europe-determined world of the United States" is not large enough for Emerson, Whitman, or Longfellow, for the revelations of the Mormons or the cadences of Gullah speech. ${ }^{6}$ Emerson and Thoreau gave themselves a past in India. The Randolphs prided themselves on their descent from the woman Vachel Lindsay called "Our Mother, Pocahontas."' Those who took it upon themselves to create not merely a new nation, but a new world order, refused the boundaries of a "Europe-determined world" for Locke's more expansive vision of America.

What we debate here is neither multiculturalism nor democracy: it is the constitution of democracy in America-not the geographic or demographic nation, but the ideal and temporal nation, the nation in history. We-we multiculturalists-do indeed aim at remaking those ideal and temporal boundaries. We have found elements of the American past in Africa, in Asia, and in American cultures preceding the arrival of the Europeans. We recognize that the histories and the canons that have occupied places of privilege in the American academy and in American popular culture do not do justice to America.

I argue-in terms that accord with the values the opponents of multiculturalism profess-that multiculturalism does more than justice to America. Multiculturalism does America good. It secures virtues we have at our best, and presents obstacles and correctives to vices we have at our worst. It offers us an invitation to reclaim ancient virtues.

Democracy in America has certain modern, bourgeois virtues that I would like to praise. The first is responsibility.

The pretense that history is the objective record of "what happened" is at best evidence of a naivete inappropriate to a scholar. When we write our histories we are engaged in a constitutional enterprise. We choose which aspects of the past we will regard as constitutional. We designate those historical moments when we (as a people) have been - and when we have failed to be-true to our word.

We multiculturalists take the second enterprise-the memory of our faults - to be as important to our constitution as the first. We cannot have the histories of our choosing. Honor forces us to acknowledge our sins and our failings as a people. Yet though we cannot have the histories of our choice, we do have a choice among histories. We choose what in the past we will remember, record, recall. 
Justice may not end with paying one's debts, but assuredly it begins there. Insofar as it reminds us of the contributions and (let us not mince words here) the suffering of subaltern groups in America, multiculturalism holds us to an ethic of responsibility, it calls us to account. In doing so, we perform for the nation the service Socrates performed for the Athenian citizen. "I shall question and cross-examine him, and if I find that he does not possess virtue, but says he does, I shall rebuke him for scorning the things that are of most importance and caring more for what is of less worth."

In calling ourselves to account, we bear witness to what we wish to become, what we have been, and the space between them. We engage in a democratic automachia, we become "self-made men." It is this enterprise that makes our culture more than "the dead hand of the past." It is this enterprise that makes us more than "the booby heirs," as Randolph said, of an illustrious lineage in decline. This activity makes us founders: authors of ourselves and our nation.

When we reduce our culture to an inheritance we diminish both the founders and ourselves. We deny the founders' ability to make a nation capable of overcoming itself. We deny their ability to surpass themselves. We refuse the authority the Constitution ascribes to us. We deny the possibility that we may constitute a new world order. When he lost faith with the republic, Herman Melville wrote:

The Founders' dream will flee.

Age after Age will be

What Age after Age has been.

(From man's changeless heart their way they win. $)^{9}$

That is no democratic faith.

Democratic citizens place their faith in change. The democratic project entails faith in the capacity of citizens to put an end to the rule of history, to take upon themselves the work of providence, to become their own creators. They will not be what age after age has been. They will be the authors of a new world order. They have another bourgeois virtue. They are inventive.

Democratic citizens not only invent themselves, they endeavor to remake the world. Imagination and the capacity to invent oneself anew, to make a new world order on the foundations of the old, bottom the American constitutional enterprise. Those who would link democracy to capitalism should look to these virtues, for they link "the free market" to the commonplace practices of free peoples enlisted in the constitutional enterprise of self-overcoming. 
Those who commend the competitive nature of "the free market" should not attempt to silence debates over the canon.

Opposition to multiculturalism attempts to limit our knowledge of alternatives, to constrain our writing of history, to constrain our reading, to impose upon us a cultural and canonical hierarchy that is not subject to question. This position is inconsistent with many works in the canon it purports to defend. It removes from "Western Political Thought" the very virtue that they errantly suppose unique to it: the capacity for critique.

The opponents of multiculturalism desire the illusion of a culture of consensus, without differences, without division. Cultures are constituted in debate as well as in consensus. Those who oppose themselves to multiculturalism, arguing for adherence to a traditional canon, desire the illusion of a culture that remains constant and unchanging. They are permitted to believe this possible only while they remain ignorant of the history they purportedly prize.

Those who study the canon learn early on that its content has changed with time and context. We see the Presocratics fall in and out of favor, we see Maimonides forgotten and remembered. We see Aristotle contend with Plato, and Aristophanes ridicule him. We see Pope mock Dryden. We forget Filmer. There are, in America, generations who read Calhoun and generations who neglect him. Winthrop and Mather, Henry and Taylor, Webster and Clay, Adams and Dewey, are sometimes read, sometimes honored, sometimes forgotten.

The opponents of multiculturalism do no more justice to the texts they profess to honor. The works within even the most hidebound conceptions of the canon direct their readers outside the boundaries the opponents of multiculturalism would have us observe. Those who read the Symposium or The Bacchae find in those works elements of an unfamiliar, often alien culture. Those elements they find familiar-men in drag, for example-may be no less disturbing to traditionalists. Neither Athens nor Jerusalem can be called a wholly Western place. Those who read those works as an inheritance, adhering to an imagined Greece as a remembered place, will find that Plato and Herodotus direct them beyond it, to a deference for Egypt and Minoan Crete. Weber and Hegel, Nietzsche and Kojève, would have their readers look to their future in China and Japan. The refusal of multiculturalism requires its followers to be deaf to the teachings of the texts they read.

If it were possible to isolate a body of works whose claims to greatness would remain unexamined —or whose greatness would remain unequalled- 
we would have occasion for shame and sorrow. The belief that we can neither examine nor surpass the works that we venerate marks a lapse of faith, a failure of nerve. In it we declare that we cannot be, as a people, greater than we have been.

An unreflecting deference to an unexamined past entails a refusal of the duties of democracy. Rather than attempting to secure the blessings of liberty to ourselves and our posterity, we would endeavor to deprive our posterity of the qualities they require to rule themselves, to constitute themselves, in the most fundamental sense. That is no democratic education.

The opposition to multiculturalism not only stifles democratic virtues, it feeds - and feeds upon-democratic vices. The opponents of multiculturalism, in their disdain for the work of African Americans, Latinos, women, and others (many others), evince a primitive majoritarianism. They bow down to Randolph's "King Numbers."

A more demanding democracy requires that merit matter more than majorities. Unless you wish to make the argument that merit belongs only to the works of-whom? Europeans? whites? men? men writing before the twentieth century? - considerations of merit will produce ... multiculturalism.

The opponents of multiculturalism are much given to charges that women and minorities are attempting to find a place in the canon (or the curriculum) without merit. These charges would be more just were they reversed. In assuming that politics alone could make a place for women and people of color in the canon, the opponents of multiculturalism assume that merit could not possibly belong to them. The refusal to reexamine the canon is the issue of either an ignorant complacency or a desire to maintain an unearned privilege.

Multiculturalism encourages the bourgeois virtues of responsibility and invention, the valued (and profitable) practices of competition and self-making. Multiculturalism requires that honors be earned, and distinctions given on the basis of merit.

Certain vices Tocqueville saw in the American democracy - a relentless tendency to mediocrity, the tyranny of the majority-may be ameliorated by multiculturalism. Those who fear that multiculturalism will exacerbate sectarian hostilities would do well to recall Federalist 10. Madison looked not to the muting but to the multiplication of sects and interests to diminish the hazards of faction and the tyrannical potential of the majority.

I have argued that multiculturalism tends to preserve democratic virtues and tends to diminish democratic vices. I would like to make another claim: 
that multiculturalism may enable us to recover certain virtuous practices democracies have neglected: magnanimity, friendship, and learning.

In one form, often seen among the religious, magnanimity reveals itself in the generous excess of mercy and forgiveness. In the form of a martial patriotism, it sparks unnecessary, irrational heroism. In its constitutional form, magnanimity sets itself against the limits of history. This is the ambition that looked not to secure the once-established rights of British subjects, but rather to create a new world order. This is a virtue surpassing responsibility. From this virtue comes the desire for a polity where "justice rolls down like water, and righteousness like a mighty stream." This is a virtue of excess.

Aspects of multiculturalism cultivate this virtue. By drawing attention to the limits of history, by calling people to account and prompting them (in the well-used rhetoric of the jeremiad) to overcome themselves, multiculturalists enlist themselves in an admirably excessive project. The desire to include all, to comprehend all, has animated the projects of Lewis and Clark, NASA, the Library of Congress, and the land grant universities. Madison's vision of security in size and multiplicity, no less than Whitman's poetry, testifies to an American faith in the virtues of excess.

There are dangers in these excesses. Lockean universalism and a disposition to democratic evangelism have led to conquest and colonialism. An appetite for learning can become a passion for collection. Nietzsche saw this as one of the defects of modernity. "The modern man carries inside him an enormous heap of indigestible knowledge-stones that occasionally rattle together in his body." ${ }^{10}$ Such people are always acquiring knowledge that they never make their own. The recognition that historical learning must be made one's own, however, leaves the question of what may be one's own unanswered. The example of those who are to be born posthumously and those who are nurslings of older ages suggests that neither nationalism nor a simple linear chronology can determine the limits of what may come to be one's own.

The second virtue we should cultivate more carefully is friendship. The ancients had a high regard for friendship; moderns have neglected it. In friendship, difference is understood not as in tension with community, but as the very basis for it. Common sense and experience apprise us of our inadequacies. We turn to others to supply our lack.

We should, however, be attracted to difference not only by need, but by desire. Friendships are formed in the desire for more knowledge: the knowledge possessed by a friend, or common desire for knowledge that surpasses them 
both. Friendships are formed from the desire for more beauty, more virtue, more instances of the sublime. Those who study difference-and the different-may be similarly moved. Neither friendship nor multiculturalism requires one to abandon one's peculiar virtues. What they offer is an invitation to recognize virtue for its own sake: because it is good, not because it is one's own.

Multiculturalists know that the study of difference is no simple undertaking. We have been among the sternest critics of the Enlightenment. Yet I think we who are critical of the Enlightenment tradition advance its project more loyally than its partisans. Multiculturalists do not pretend to an understanding of history that is definitive, comprehensive, singularly authentic, or entirely objective. (They thus have a greater claim to honesty than those academics whose startling hubris has made such claims commonplace.) Yet they approach these ends-whose impossibility they acknowledge-more nearly than previous histories. They present a more comprehensive recollection of the past. Theirs is a representation of the past less subject to the interests and preferences of the powerful, more fully representative of past conditions, events, and forms of life. Their histories acknowledge their incompletion. They invite those who read them to pursue what is missing. They invite alternative interpretations. They demand that the reader abandon the passivity of the disciple for the activity of the scholar.

The academy that multiculturalists advance is obliged to question the composition of its canons, the completeness and the objectivity of its histories, to look again at neglected - and venerated-works and question their merits. These are the ordinary duties of the scholar. The nation that multiculturalists advance is obliged to become mindful of its temporal and ideal boundaries, to consider what it has been, what it is, and what it wills itself to become. These are the practices of constitutional democracy.

What then prompts fears of multiculturalism? Is America so small that it cannot contain these differences? Is the canon's claim to merit so slight that it cannot withstand question or scrutiny? If so we need a greater nation, and a greater canon.

\section{Notes}

1. Edmund Burke, Speech on Conciliation with the Colonies, ed. Jeffrey Hart (Chicago: Henry Regnery, 1964), 139, 141, 57, 137. As the matter of Burke's speech suggests, however, much variety went into the making of that seemingly uniform England. One might also consider Daniel Defoe's poem "The True-born Englishman." 
2. Burke recognized, however, that historians, politicians, and peoples choose between histories. In the Reflections on the Revolution in France, Burke castigated the French revolutionaries for choosing the wrong history.

3. Stephen Vincent Benet, "Invocation," in John Brown's Body (New York: Rinehart and Company, 1941). Benet writes of America:

I think that I have seen you, not as one,

But clad in diverse semblances and powers.

4. "D'un animal stupide et borne, fit un etre intelligent et un homme." Jean-Jacques Rousseau, Du Contrat Social, ed. Ronald Grimsley (Oxford: Oxford University Press, 1972), 119.

5. Vachel Lindsay, "Bryan, Bryan, Bryan, Bryan," in Selected Poems of Vachel Lindsay, ed. Mark Harris (New York: Macmillan, 1963), 124.

6. I have in mind Emerson's poem "Brahma" and his other references to Indian and Persian thought, Longfellow's poem "Hiawatha," and the scriptures of the Church of Latter Day Saints that give Jesus Christ a past in America. The quotation from Hannah Arendt comes from The Origins of Totalitarianism (New York: Harcourt Brace Jovanovich, 1979), 191.

7. Vachel Lindsay, "Our Mother, Pocahontas," in Selected Poems, 115-17. For Lindsay, in this poem, American identity entails a refusal of Europe.

We here renounce our Saxon blood.

Tomorrow's hopes, an April flood

Come roaring in. The newest race

Is born of her resilient grace.

We here renounce our Teuton pride;

Norse and Slavic boasts have died:

Italian dreams are swept away,

And Celtic feuds are lost today.

Robert Frost echoes this argument in "The Gift Outright," the poem he read at Kennedy's Inauguration.

8. Plato, The Apology, trans. Harold North Fowler (Cambridge: Harvard University Press, 1977), 109.

9. Herman Melville, "The Conflict of Convictions," in Battle Pieces (Amherst: University of Massachusetts Press, 1972), 17.

10. Friedrich Nietzsche, The Use and Abuse of History (Indianapolis: Bobbs Merrill, 1957), 23. 


\title{
Chapter 9
}

\section{Multiculturalism and American \\ Liberal Democracy}

\author{
James Ceaser
}

Practical inquiry in political science focuses on the question of how different causes contribute to the maintenance or destruction of various forms of government. These causes include such factors as the character of the economic system, the arrangement of political institutions, and the kinds of political and intellectual doctrines that prevail in society. The centrality of the concern about the form of government (or the regime) stems from the fact that the regime is the "house" or structure in which a people lives. As such, it helps account for the quality of life of any people and for the chances it may have to survive and prosper.

The "ism" at the end of multiculturalism suggests that, like certain other "ism" terms used to define a doctrine in political life, multiculturalism is a kind of ideology. A political analysis of multiculturalism, such as I propose here, should therefore explore the consequences of this ideology for the maintenance or destruction of liberal democratic government in the United States. Does multiculturalism function to support or undermine American liberal democracy? If multiculturalism works to undermine American liberal democracy, does it support some alternative form of government? What would that alternative be, would it be viable in the United States, and would it be preferable to a liberal democracy? To answer these questions, we must seek first to define the key terms, beginning with multiculturalism itself.

\section{What Is Multiculturalism?}

An older and perhaps literal meaning of a multicultural system refers to the situation in which a number of different "peoples" or "nationalities" live together under the same government. Under this conception, the question of establishing a viable multicultural state is that of how to accommodate 
different peoples and secure for them-as one possible solution-a degree of recognition and autonomy while still providing for an adequate conception of national unity. This question has a long history in political science and was a subject of study in imperial Rome as well as in the Austro-Hungarian empire. It is of obvious concern in states today that contain identifiable national groups living in distinct territories. In some instances, schemes of federalism or regional government have been developed to provide varying degrees of autonomy for subnational groups, as in the cases, for example, of Switzerland, Belgium, Canada, and Spain. In other instances, governments have attempted to solve the challenge of a multiplicity of peoples by ignoring or repressing these differences. A survey of the different cases in this area would almost certainly demonstrate no single "best rule," as the character of each situation is so distinct.

This older question has little to do, however, with the intellectual doctrine known as "multiculturalism" in the United States. Oddly, this elementary point seems to have escaped many political theorists, who move from the older and more literal meaning of the term to its American case. Thus, in a recent and widely read book on multiculturalism entitled Multiculturalism and "The Politics of Recognition," which consists of a long essay by the Canadian political theorist Charles Taylor followed by commentaries by a number of American scholars, the authors become so interested in their theoretical inquiries that they hardly pause to notice the vastly different political situations they are addressing in both countries. ${ }^{1}$ Canada faces the traditional issue of two peoples in the same nation, while the problems in America are of an entirely different sort. The groups counted as "cultures" in the American context (according to the book's editor, Amy Gutmann) include "African Americans, Asian Americans, Native Americans, and women." Excepting the case of a few Native American tribes, none of these "cultures" is seeking a separate region and government where it would exercise juridical sovereignty and live as a partially distinct political society. The inclusion of "women" on Gutmann's list of "cultures" renders any such notion highly impracticable: No traditional conception of "peoples" or "cultures" has ever divided men and women into distinct "peoples," and no society would be able to long survive if such peoples were physically separated.

The slogan of our day that American intellectuals have helped export to the rest of the world is "multiculturalism" —or, for those who prefer the more philosophical title, "the politics of difference." Multiculturalism is being addressed everywhere in the international republic of letters-in symposia, 
books, and in-depth essays. It has been identified by some as the major ideology of Western intellectuals in the wake of the collapse of communism. Yet inside America, where multiculturalism seems on the surface to be the strongest, it is also the most difficult to define or characterize. It has been used to designate policies as mild as those that would require students to learn more about nonmainline European groups and as controversial as plans to eliminate study of the "canon" of Western thought or schemes to transform the Constitution in order to guarantee political representation for various minority groups.

Multiculturalism in the United States, for the purposes of this essay, will be taken in one or another of its stronger senses. So let us remind ourselves - as if most in the arts or academia today need to be reminded! - what American multiculturalism means as an intellectual "ism." Citing some examples might prove instructive. On college campuses today, proponents of multiculturalism can regularly be found demanding that more women and "people of color" be hired on the faculty to overcome the "male, Eurocentric" bias of the current education system. Multiculturalism here refers to different biological groups reputed to hold different value systems. In the art world, in 1992 there was a major "multicultural" exhibit at the Whitney Museum in New York in which one requirement for inclusion was that the art focus on the experience of being "marginalized." White males who visited the museum were asked to wear buttons proclaiming their guilt. The exhibit included - as an example of art-a famous television videotape made by an observer at the scene (named Holiday) in which Rodney King (a black man) is shown being beaten by four white Los Angeles policemen. In the words of the museum's curator, "There's a long history of art showing us something about the world, and the Holiday tape adds a new dynamic to that tradition." ${ }^{3}$

If these examples reveal something of the character or "spirit" of multiculturalism in America, can we now give it a more precise definition? Unfortunately, this is difficult, as the term itself often hides or conceals its real meaning. Just as it was once said of the Holy Roman Empire that it was neither Holy nor Roman, nor in its later stages an empire, so it should be said of American multicultural theory that it is neither multi, nor cultural, nor at this stage genuinely theoretical.

1. Let me develop each of these points, starting with the claim that multiculturalism is not essentially "multi," or "plural." It is on the contrary binary, 
or dualistic. The main structure of the theory-the categorization schema under which it "constructs" the world-lays everything out on a binary grid based on the distinction between the Oppressor and the Oppressed, or (to use the current jargon) between the "Hegemon" and the "Other." This binary distinction lies at the core of high-brow multicultural discourse in America. If ordinary political scientists have not yet met the Other, they should get prepared to do so, for She will surely be making her debut in professional journals like the American Political Science Review, no doubt fortified by a panoply of regression equations.

The Hegemon-Other distinction has been aptly defined and sketched by Charles Taylor. Those with the "hegemonic power" possess above all the power to bestow or to fail to bestow recognition. The failure to recognize another culture "can inflict a grievous wound, saddling its victims with a crippling self-hatred." The victim-misrecognized and marginalized-is the "Other," the "voice" that is submerged. This same distinction is made by Iris Marion Young, author of the influential The Politics of Difference. According to Young, the pervasive experience of America is that of "cultural imperialism," defined as a situation in which "the dominant meanings of society render the particular perspective of one's group invisible at the same time as they stereotype one's group and mark it out as the Other."

Every ideology or discourse contains a standard for determining honor and distributing praise and blame ("valorizing" and "devalorizing," to use the current jargon). The system of honor in multicultural theory derives from this binary structure of thought. The "Other," as anyone who reads the literature in this field will appreciate, is more than a term of description; it is a term of distinction. Other is the one who, having had her "voice" silenced for so long, will now at last be heard, while Hegemon, having misrecognized her, should now be silent. The two chief passions that multiculturalism attempts to foster derive from this distinction. These passions are supine contrition (on the part of the Hegemon) and aggressive resentment (on the part of the Other). These are exactly the passions that the exhibition at the Whitney Museum was meant to stimulate.

Despite, therefore, its blistering critique of American society, multiculturalism is at heart a curiously upbeat and melioristic ideology. It is designed, somehow, to reverse the awful situation it describes. The discourse of multiculturalism is strangely dependent on contemporary "liberal" (i.e., mildly leftist) thought, or at any rate on the tolerance and compassion that 
this thought has tended to promote. This dependency is easily seen from the fact that if the hegemonic culture actually acted in the way it is depictedif the Hegemon behaved with confidence as an oppressor-it would use its power to suppress the Other. But while the Hegemon frequently does act to maintain his power-which is what lends some plausibility to the discourse-one objective of multicultural discourse is to induce the Hegemon to act in just the opposite way and yield his stronger place-to "roll over" and to assume the (standard) academic position of apologizing first and asking permission second. (Hegemony should be made of sterner stuff!) Only, therefore, where one may presuppose a strong underlying sentiment of compassion or guilt, a characteristic sentiment of a powerful element inside of all liberal democratic societies, will multicultural discourse have the desired effect of eventually defeating the Hegemon. Multiculturalism thus has a symbiotic relationship to the compassionate strand of liberalism, which is why it fares so well on many university campuses.

Although the primary criterion of categorization in multiculturalism is binary and not multi, a multi or plural dimension does play a secondary role. After the societal pie has been divided into its two large pieces (the Hegemon and the Other), multicultural theory goes on to split the "Other" into a multiplicity of "cultures." In public discourse, proponents of multiculturalism often allow the binary distinction to fade into the background (it sounds too harsh), preferring instead to speak of tolerance among a variety of different cultures. It is by means of this rhetorical technique that proponents of multiculturalism succeed in leaving the impression that their discourse is fundamentally "multi." The subordination of the category of multiplicity to that of the binary distinction is nonetheless easily observed. Thus, the multiplicity of cultures (which is presented as a nice thing) is only admitted to exist in the category of the Other, not in the category of the Hegemon. The Other is always plural, a veritable cornucopia of skin pigmentations, linguistic groups, and alternative sex preferences: blacks, women, Asians, Latinos, Amerindians, gays, lesbians, and so on. Meanwhile, the Hegemon for all practical purposes is always an undifferentiated one: the white, or the white European, or the white European-descendant males, or the Anglo white European descendant males-or what have you. Lost, somewhere, in the category of the Hegemon are all those subtle shades of white that exist among Minnesotans of Norwegian, and Finnish, and Swedish origin, not to speak of the differences between the blond Aryans and the various groups whom the father of racist theory, Arthur de Gobineau, 
once classified as the "rubbish" (détritus) of Europe dumped on our shores: the Irish, Germans (mostly unpure), and Italians.

To allow the Hegemon to be plural might, of course, break down the whole structure of the ideology. For if the Hegemon were plural, then it too would contain a multiplicity of cultures, some of which would certainly have enjoyed the distinction of being oppressed and misrecognized. This admission would call into question the claim that only groups inside the marginalized Other are "cultures" that merit recompensation.

The primacy of the binary (Hegemon-Other) over the multi in multiculturalism can again be seen in instances when, for example, someone from a cultural category designated objectively as Other does not share the multicultural doctrine of marginalization. Multiculturalism then assigns such people to the status of nonbeing by the claim that such a person is not "really" what he or she is. Try, for example, to recommend a woman for a women's studies program who is not a feminist and see how quickly the concern for "diversity" is redefined to be understood in a "broader context." Or consider the racial status among multiculturalists of African-American Supreme Court Justice Clarence Thomas. Such persons, their gender or color notwithstanding, are considered as "inauthentic."

What is the source of this binary schema of Hegemon and Other? It seems doubtful that it reflects a natural division. No anthropologist to my knowledge has ever recorded indigenous peoples in their native habitat discoursing about "Hegemons and Others" (though they do frequently hold to some such distinctions as "one's own" and "foreign.") Multicultural categories are thus, in today's preferred language, "cultural constructs"-indeed, constructs of rather recent origin. Multiculturalism is the direct heir, transferred onto the American scene, of a species of modern philosophical thought. This is the view of proponents of multiculturalism itself. Turning once again to Iris Marion Young: She finds that the source of the idea of "difference" (or multiculturalism) lies in a powerful critique of rationalist enlightenment thought that was made by Theodore Adorno and Jacques Derrida (originally, in fact, by Martin Heidegger). This critique-the reader must forgive me the abstractions here-holds that "reason" or the "logic of identity" reflects an "urge to think things together [and] to reduce them to unity.... Reason seeks essence, a single formula that classifies concrete particulars as inside or outside a category." This way of thinking misses multiplicity ("denies or represses difference") and constructs a political field in which there is imperialism and marginalization. Cornel West, while not 
making the connection quite as exclusive, emphasizes "the oppressive deeds done under the ideological aegis of the notions" of "necessity, universality, rationality, objectivity, and transcendentality."

Reason so conceived is the source of our deepest political problem today: repression and the marginalization of difference. Repression in liberal societies is all the more insidious for being "hidden" and done under the cover of universal principles. According to Young, "The irony of the logic of identity is that by seeking to reduce the differently similar to the same, it turns the merely different into the absolutely other." Translated into politics, rationalism results in the various "isms" of repression endemic to America, such as sexism and racism - in short, the very dichotomous or binary way of thinking that gives us the distinction between the Hegemon and the Other. Here then is the startling (and "ironic") conclusion. The universal ideas of American liberalism become the sources of modern repression. Enlightenment thought, including the thought of America's "republican fathers," "explicitly justified the restriction of citizenship to white men on the grounds that the unity of the nation depended on homogeneity and dispassionate reason."7

All this abstract talk_- "essences," "categories," and the "universal versus the particular" - may perhaps serve to excite a few of the philosophically minded, but it is clearly too bloodless to move the mass of intellectuals. It requires a more concrete discourse, which is now being supplied by the fields of American studies and American history. In her recent presidential address to the Organization of American Historians, Joyce Appleby proclaimed that it is now time for American historians to adopt a new "narrative" that is faithful to the premises and methods of "multicultural history." The old narrative taught that the fundamental principles of liberty and natural rights were antidotes to oppression, and that slavery, racism, and unequal treatment derived from other parts of the American experience. Yet according to multicultural history, it is America's fundamental principles that cause or are inseparable from oppression. The ideals of liberty and equality, far from being antidotes to oppression and racism, are now more or less bound up with it. The core American creed, according to Richard Sennett, makes up a nationalist "myth," which "legitimates attacks on peoples whose lives are different." Appleby, while not denying the "enviable freedoms we Americans enjoy," wants to help us see the "oppression exercised by [our] omnipresent cultural model." America's dedication to the "cultural artifact" of its revolutionary principles, she contends, has covered up our real experience and prevented us from appreciating our "authentic diversity." 
There is perhaps another source of multiculturalism. Charles Taylor has traced it to the ideology of third-worldism that was articulated by Franz Fanon..$^{10}$ Third-worldism is a racialist restatement of Lenin's theory of imperialism, which therefore makes multiculturalism a sort of Marxism with a cultural face. Some have accordingly sought to trace multiculturalism back to Marx and even further to the psychology of recognition as discussed by Hegel and ultimately Rousseau. ${ }^{.1}$ Whatever the source, however, multiculturalism is a pure artifact of dead white European male thinking, and it can be reconstructed from the works that appear on the multicultural Index, otherwise known as "the Canon."

It may be worthwhile to pause a moment to speculate about whether its binary schema manages to help us capture what is "out there" in the world, assuming one can speak of a social reality that is not merely constructed. In some measure, of course, the multicultural narrative has focused on an important reality. Without the fact of European colonialism, the fact that whites enslaved blacks purely on racial grounds, the fact that Europeans either conquered or exterminated the Amerindians, the fact that males have largely dominated females, and the fact that race (as distinct from intracaucasian ethnicity) has been used at one time or another as the basis for official (legal) discrimination in the United States-without all of these facts, it is almost inconceivable that so many well-educated people could find so powerful an appeal in multiculturalism.

These facts stand on their own. The question is whether they add up to the full-blown doctrine of multiculturalism. One may doubt whether they do. The binary schema of multiculturalism produces some remarkable distortions. It suffers, in fact, from all of the limitations of a schema that overlooks, if the term may be used, "difference." The dualistic approach leads multiculturalism to miss what a more supple and pragmatic theory could easily detect. There is almost no form of oppression said to occur between the Hegemon and the Other that has not occurred-and fairly recentlyamong groups within the category of the Hegemon (and, for that matter, among groups inside the category of the Other). White tribes have decimated each other with as much savagery and fury as they have "peoples of color"; and "peoples of color" have oppressed each other with no less vigor than have white people. Within this decade alone, there has been ethnic cleansing among whites in the former Yugoslavia and genocide among blacks in Rwanda. Within this century, white Europeans have visited upon other white Europeans a degree of savagery that probably knows no parallel in 
human history. If there is any one single indicator of a common human nature, is it not in the universal tendency of peoples of all colors and stripes to oppress and abuse one another? ${ }^{12}$

Distorting the record of history may be the least of the costs of this binary mode of categorization, for every sophisticated person today knows that one man's historical record is merely another woman's "narrative." Yet a distortion of experience may prevent us from dealing with the concrete reality with which we must deal in America today. The doctrinairism of multiculturalism stands in the way of examining the means by which various groups have been able to move in America from a marginalized status in the past to achieve a place of approximate equality today. Analyzing how such changes took place might then be compared with the current policy approaches advocated by proponents of multiculturalism today. Allowing, as one should, for the uniqueness of each political situation, one could then at least begin an informed discussion of which strategies offer the best prospects for improving the lot of burdened groups and for maintaining the stability of liberal democracy.

2. Multiculturalism, I also noted, is misnamed because the movement itself is not cultural. Cultures are not (usually) multicultural, and multiculturalism is not (quite) a culture.

On the first point, cultures are often proud of their superiority and hostile to other cultures. Cultures are, in a word, often intolerant, not only of other cultures, but of individual rights as well. They can be closed, dividing the world very clearly between an "us" and a "them," between the civilized and the barbarian.

As for multiculturalism itself, it hardly seems that it can qualify as a full or authentic culture. On what would such a culture be based? Multiculturalists have a jargon of their own, but scarcely a genuine language; they are filled with passionate convictions, but these are not quite the same as a common set of religious beliefs. The only possible basis on which multiculturalism could become a culture would be on the ground of a belief in the poles of the Hegemon and the Other. Yet not even multiculturalists, apparently, think that these abstract categories carry the "thickness" to be able to bear the weight of a culture. Cultures are almost always described as involving something deep-seated and rooted, something that evolves and is not 
formed overnight. (Still, a good part of modern feminist "culture" does take its direction from this kind of thought; the deepest element of this culture is the "experience" of victimization, which has been heightened by the philosophy of "difference.")

At most it appears that multiculturalism is a kind of add-on or overlay designed to modify other cultures. Each culture is to remain fully itself, but also (somehow) to slip on an outer jacket of multiculturalism. Thus, to qualify as a culture in the multicultural club, each culture must "take the pledge" and, if need be, change itself by agreeing to respect the worth of every other culture (as well, most add, as the rights of individuals). Thus, Chinese culture must give up its traditionally hostile views about women, Chicanos their traditionally hostile view of gays, and so forth. There is a slight difficulty here, however. Multiculturalism so conceived becomes almost a species of Eurocentric culture, for the "pledge" has grown out of a post-Enlightenment, Western intellectual movement. Why the various cultures should agree to abandon their own beliefs and accept the imperialism of the ideology of difference is never made clear. Nor are multiculturalists exactly in the best position to insist that submerged cultures really accept such pledges of tolerance, given their starting premise about the equal validity of all cultures.

One might even argue that multiculturalism dissolves any kind of genuine culture. If our only culture is the multiculture, that is, the common partaking by all Americans in all of our multiplicity of cultures-a kind of mixing in which, so to speak, you eat kosher one night, Italian the next, and Chinese (with pork fried rice) the next — what really remains of the idea of culture? In any case, is not this kind of constant "tasting" of cultures really the province of a cosmopolitan elite that is detached and sophisticated enough to delight in the customs of different peoples who themselves are not quite as sophisticated as those enjoying the diversity of customs? For if the masses were ever to adopt this mishmash as their "culture," rather than sticking predominantly to one culture, what sort of genuine or rooted cultures would remain? How far can one go in this direction without losing real cultural roots?

These alternatives represent three theoretical possibilities for the "culture" of multiculturalism. Yet the most likely result of this movement may well be none of these three, but instead the encouragement of "culturalism" pure and simple, that is, "tribalism" or "nationalism." Multiculturalism is a curious movement. If ever it becomes a mass movement, the multiculturalists (who preach the value of multiplicity or difference) are almost certain 
to be outnumbered by the culturalists (who are devoted to the beliefs of their own particular culture). The culturalists, moreover, invariably appear as more "authentic" than the multiculturalists, because the culturalists espouse their beliefs in full simplicity without the need of going through an elaborate exercise of intellectual consciousness raising. The culturalists, moreover, are "the peoples of color," as witness, for example, the Nation of Islam. Finally, the culturalists are likely to be more resolute. The multiculturalists are thus in danger of becoming the dupes of the culturalists. Many who march under the banner of multiculturalism do not believe in the "multi" at all, but merely recognize the tactical benefits to be had from joining a temporary coalition against the "Eurocentric" power structure.

The culture that comes closest to the (tolerant) multicultural idea is liberalism. Yet liberalism in its best statement is not the same thing as benign multiculturalism, however tolerant liberalism itself may be of the diversity of different cultures. American liberalism has assigned the primary public or legal identity to the individual, while it has accorded the culture or group a secondary and less formal status. Multiculturalism, while wandering all over the place in regard to its view of the individual, in the end assigns or consigns every individual to a "cultural" unit; it is finally a group philosophy. It thereby tries to raise the "cultural" unit to the first rank in our thinking about society and justice (as well, of course, as in the assignment of legal benefits). Even when it comes to rights, the multiculturalists who play the current Harvard Law School "trump" game prefer to play their card with group rights, not individual rights. They "privilege" group culture.

3. Finally, multicultural theory is not really theoretical. If it were theoretical, it would (as that word "theory" implies) examine the major categories or phenomena it claims to investigate. Yet multiculturalism is without much insight into its own central term: culture.

What is a culture? Does it refer to specific language communities, religious groups, ethnic groups, races, sexes, or what? Multiculturalism has no answer, beyond playing off various meanings of the term as they exist today. This is more of a problem in the case of the word "culture" than for almost any other word of which I am aware. For "culture" is a word that refers today to no clear "natural" phenomenon; it is not a term of common sense. Rather, it is a category with a complicated history-a term that different schools of thought have sought to capture to pursue different programs. 
The imprecision that attaches today to the term allows those who use it to "play off" of all sorts of traditions without achieving any kind of coherence of thought.

There is something deeply disturbing in the existence of a whole school of thought ("multiculturalism") that is so imprecise about its own language. I offer only one example of the incoherence into which this leads many today. The use of the term "culture" in cultural anthropology was a kind of creation of Franz Boas. Boas adopted the term "culture" in an effort to argue that the primary human groupings were formed by different patterns of socialization rather than by different biological or racial characteristics. In other words, the concept of culture in anthropology was designed explicitly to replace race as that discipline's central organizing category. "Culture," Boas wrote, "is the result of innumerable interacting factors and there is no evidence that the differences between human races... have any direct influence upon the course of development of culture."13

Multiculturalists play off this idea, frequently claiming that they are speaking of different "cultural" groups in this sense. Yet to the extent they actually make use of the term for practical purposes (as in demands for cultural diversity), culture, for multiculturalism, is invariably expressed in terms of certain racial and/or biological (sexual) divisions or practices, each of which is supposed to embody something genuine and cultural. Thus the "cultures," when it comes down to it, are white males, women, gays, and "peoples of color" (African American, Asians, Amerindians, and "browns"). Latinos sometimes slip in, notwithstanding that they are not a racial group. For the most part, they are presumed brown.

But these categories eliminate some of the real elements of "cultural" diversity, even in the ordinary understanding. Racialism and biologism, for example, deny religion as a source of culture. Hegel once wrote, "Religion is the sphere wherein a people gives itself the definition of what it regards as true." ${ }^{14}$ By this criterion, one of the most important cultural divisions in modern American society might well be between secularists and Christian fundamentalists. Yet the latter have by and large been excluded from multicultural discourse. In a recent debate of a major college faculty, a suggestion that "diversity" in the faculty should reflect this religious dimension of culture was taken by multiculturalists to be a joke. Perhaps it was intended to be. But on whom?

Meanwhile, multiculturalism ascribes status to "cultures" that have scarcely existed as such but that have been called into being by multicultur- 
alists and bureaucrats in order to derive and confer certain benefits (such as "minority" congressional districts, proportional representation on boards, and positions on university faculties). For example, one may question in what way Asian Americans form a distinct "culture." There are, of course, Japanese Americans, Korean Americans, Chinese Americans, Cambodian Americans, and so forth. But did these groups ever constitute a single "culture," except in the mind of a few intellectuals and governmental bureaucrats? Much the same can be said of "Hispanics" or "Latinos." While (once) sharing a common language, Latinos may have little more in common with each other than the members of the various cultural groups who speak English. The Hispanic "category," as anyone who has studied this issue recognizes, is in no meaningful sense a "culture." Yet multiculturalists have invested these entities (invented circa 1970) with all the reality and dignity of those who can trace their roots to a genuine cultural tradition.

Why should one demand precision in defining culture from multicultural theory, when no one else has succeeded in giving it a satisfactory definition? This is a fair question. But much more rides on multiculturalism's conception (or lack thereof) of culture, for multiculturalism has transformed "culture" into the major category of social reality. Many important benefits are now regularly distributed according to some understanding of the term. "Culture," or "minority status," is already ensconced in a myriad of laws and public policies and is used now as a matter of course in defining legislative constituencies, in allocating jobs, and in determining how to fulfill expectations for "diversity."

\section{What Is Liberal Democracy?}

Liberal democracy is a system that (a) provides the mass of citizens with the authority to select most public officials and determine the basic direction of government policy; and (b) guarantees the protection of basic rights for all individuals, and thereby as well in some degree for different groups or corporate entities.

What are the possible relations of liberal democracy to "cultures"? Scholars have recently sketched out three basic models or possibilities: (1) the public sphere designates one culture to be privileged and makes its maintenance an official project, but still provides adequate protection for individual rights and the rights (within reason) of minority cultures; (2) the public 
sphere is neutral among cultures, regarding individuals (not cultures) as the primary entities in the public space; (3) the public would seek to recognize, accommodate, and publicly promote the diversity of cultures as a primary object of society, while maintaining basic protection as well for the individual and individual rights.

The actual status of the American experience, however, fits none of these models exactly. Both opponents and proponents of multiculturalism-each for their own reasons - have found it expedient to identify traditional American liberal democracy (or at any rate its ideals) with the second model of "neutrality." While there is something to this characterization (especially when compared to the other two alternatives), this model remains something of a caricature. For one thing, the idea that American liberalism isor would wish to be-wholly "neutral" is fanciful. Anyone who thinks realistically about society knows that a notion of neutrality as between all things now claimed as "cultural" is impossible. The Constitution does not say, for example, that English is the national language of the United States (though the Constitution was written in English); but the nation is not really "neutral" about this fact.

Nor can American liberalism be said to have ever been wholly individualistic. The character of American society has always involved extensive action and interaction of groups or (sub)cultures. For example, if one reads any account of how deals for representation were decided in cities like Chicago, one quickly sees that group (or cultural, or community) considerations were always extremely important. Any notion that American life has ignored such cultural factors-or even that most have pretended to ignore them-is chimerical. It was recognized, especially at lower levels of government and within various institutions (such as political parties), that group or "cultural" considerations would in fact play an enormous role, and their influence would be enmeshed, formally and informally, in all manner of ways. The most insidious of these ways were the laws and practices involving racial discrimination against Asians, Amerindians, women, and above all African Americans.

Whatever the role of these groups, however, the national ideal, or "best statement" of American liberal democracy—not always recognized in fact, to be sure-has been one that involved formally recognizing individuals, not cultural groups, as the core of the compact of society. The highest principle was that of all persons being created equal, with the rights and privileges attaching in the first instance to individuals. Cultural groups, in this view, 
are seen mostly as the associations of individuals, having a secondary status. This idea is now the one that multiculturalism implicitly calls into question.

The history of constitutional law of the past half century has consisted of two basic stages. First, in order to fight against the discrimination in the lower levels of government and in all the other major institutions, there was a massive extension of the "formal" principle of color-blind individualism into local spheres and into the practices of various institutions. The extension of this principle thus came to be thought of more and more (by many) as the ideal of American liberalism, because this extension was undertaken in the name of eliminating racial injustices. It went so far, as both a legal principle and a norm, as to call into question or discredit the idea of group institutions or associations. Integration was pushed as a norm or legal requirement into ever more areas of society, in many cases beyond the preferences of majorities of nearly all cultural groups.

The various groups under this regime did not always achieve what they wanted under this principle. Color-blind (or sex-blind) legal status for individuals did not bring the progress that many hoped for. The policies based on this idea could not root out all current discrimination. Many came to believe that it was necessary to go deeper than the problem of current discrimination and deal directly with historical legacies. Justice was to be attained more by correcting matters for groups than for individuals. Again, in a slightly different vein, African Americans now began to occupy major positions of power in local governments; as they did so, they found that many of the old mechanisms once used for "recognizing" groups were not easily available to them because of the constraints of all the new formal color-blind principles. (For example, black big-city mayors did not control delegates at the party conventions or have as much say over local jobs and contracts.)

The frustration at the lack of progress under the color-blind system brought another stage of constitutional development, which began about a quarter century ago and which has dramatically modified the previous individualist model. It has done so not by relaxing the degree of legal restrictions and allowing local and informal mechanisms to reassert themselves, but instead by a model that increasingly asks the government formally to recognize certain groups or "cultures" and then to require benefits to be distributed on the basis of this cultural identity. We have thus increasingly formalized and "constitutionalized" the cultural unit. American law and practice are now pervaded by "culture"-based principles, applied and sanctioned at the very highest levels of federal and constitutional law. This last legal transformation 
preceded in many respects the intellectual movement of multiculturalism. But it is fair to say that more and more, multiculturalism provides the contemporary grounding for this legal regime, incorporating the entire history of civil rights into the discourse of the Hegemon and Other.

\section{Does Multiculturalism Help American Liberal Democracy?}

Will multiculturalism strengthen or weaken American liberal democracy? It is quite possible, even likely, that the multicultural movement has contributed to achieving some goals sought by previous reformers. But at what cost? That cost, I would hazard, is to undermine some of the important props of liberal democracy, without offering any coherent idea of what alternative might replace it. Consider the following liberal doctrines that are threatened by multiculturalism.

1. Multiculturalism has shifted the relationship—both legally and in our general way of thinking - between the individual and the "culture" in a way that gives far more weight to the "culture" and far less to the individual. As a sociological matter, the "cultural" element has always played a significant role, but the legal standard of individualism provided support to individuals who sought to break from a currently constituted cultural group. Today, cultural identity has been recognized in the law and enshrined in the ideological notion that we are all "cultural" animals, with "cultural" referring mostly to biologically defined criteria. Individuals in many ways-witness our college campuses - are pushed into greater "cultural" solidarity.

2. Multiculturalism has "socialized" the notion of culture itself, making it into a matter of government determination. Whatever the idea of "culture" has meant inside of American liberal democracy, it has been left in large measure for private arrangement and adjustment to define — or at any rate within local communities. Culture was something too important-or too vague - to be defined directly by the government. Shifts that took place in cultural identity thus were not officially established and did not need to be disestablished at the national level. Being "German American" might once have been considered important for everything, from artistic projects to political representation. Now, however, "cultures" are locked in by formal rules and laws, with the determinations made by various public bodies, including the Congress and the Supreme Court. This is a system that we may find difficult, if not impossible, to adjust or dismantle. 
3. Multiculturalism degenerates into culturalism based largely on race and biology. The problem of integrating a diverse populace into a people possessing sufficient unity has been ignored in favor of playing up our "needs" as cultural beings. The failure to concern ourselves with creating a primary national identity-to have people feel, as Lincoln once put it, that they are "blood of the blood, and flesh of the flesh, of the men who wrote [the] Declaration"-may be an omission we shall shortly begin to rue.

4. Multiculturalism perpetuates a perverse psychology. Proof of victimization, established generally today by the possession of some biological characteristic, is the basis of any claim to honor or position. People of different groups thus vie in an unseemly process to claim that they have been oppressed-even in cases when they manifestly have not been. The real differences among various groups are thus overlooked.

5. Multiculturalism blinds us to the (or a) meaning of our own history. In multicultural history, the heart of the American experience has been one of racism and biologism. The dominant strain of the American founders' thought rejected the notion of "culture" rooted in tribal and biological principles. This thought either has been ignored or else has been twisted into a principle that somehow is said to perpetuate racism and oppression. There is something more than merely ironic in a reading of American history that embraces a new yoke of biologism while dismissing a principle that has given hope that biologism might one day be overcome.

Can multiculturalism be eradicated in a way that will avoid the extremism of a "cultural" reaction? One would like to think it could be, but this is far from certain. The time, regrettably, may soon be approaching when each person may face the choice of attempting to save his or her own "culture" first. Any victory on these terms cannot be a victory for American liberal democracy.

\section{Notes}

1. Multiculturalism and "The Politics of Recognition": An Essay by Charles Taylor, with Commentary by Amy Gutmann, Steven C. Rockefeller, Michael Walzer, and Susan Wolf, ed. Amy Gutmann (Princeton: Princeton University Press, 1992).

2. Amy Gutmann, "Introduction," Multiculturalism and "The Politics of Recognition," 3.

3. Incidentally, the same "art" dealer who supplied the King tape to the Whitney also offered Timothy Goldman's film, from the 1992 riots in Los Angeles, which features a 
(white) truck driver being pulled from a truck and beaten by three (black) men. The Whitney curators decided against using this piece of art, judging that it lacked a comparable artistic "dynamic." See Suzanne Muchnic, "King Beating Footage Comes to the Art World," Los Angeles Times, 10 March 1993, F8.

4. Taylor, Multiculturalism and "The Politics of Recognition," 25, 26.

5. Iris Marion Young, Justice and the Politics of Difference (Princeton: Princeton University Press, 1990), 59.

6. Cornel West, The American Evasion of Philosophy: A Genealogy of Pragmatism (Madison: University of Wisconsin Press, 1989), 208.

7. Young, 98, 99, 111.

8. Richard Sennett, "The Identity Myth,"New York Times, 30 January 1994, sec. 4, p. 17.

9. Joyce Appleby, “Recovering America’s Historic Diversity: Beyond Exceptionalism," Journal of American History 79, no. 2 (September 1992), 430, 420, 429.

10. This connection has been noted by two leading political theorists, Charles Taylor, Multiculturalism and "The Politics of Recognition," 65, and Thomas Pangle, The Ennobling of Democracy (Baltimore: Johns Hopkins University Press, 1992), 79.

11. This is the thesis of Charles Taylor, which is seemingly endorsed by other political theorists writing in the same volume, including Amy Gutmann and Michael Walzer.

12. Thomas Hobbes's famous remark about commonwealths might nearly as easily apply to "cultures": "There is scarcely a Commonwealth in the world, whose beginning can in conscience be justified" (Leviathan, "Review and Conclusion").

13. Franz Boas, The Mind of Primitive Man (New York: Macmillan, 1938), 195.

14. Georg F. Hegel, Reason in History, trans. Robert Hartman (New York: Macmillan, 1988), 64. 


\title{
Chapter 10
}

\section{Liberal Democracy, Universalism, and Multiculturalism}

\author{
Marc F. Plattner
}

I come to this subject as someone who has had no involvement in America's internal wars over multiculturalism but who has been engaged on a daily basis in a very different struggle- the effort to expand and strengthen democracy around the world. What has struck me, however, as news from the multicultural battlefront has filtered into my consciousness, is the extent to which these two intellectual and political struggles appear to be tending in opposite directions.

On the global front, at least insofar as one is speaking of the realm of ideas, the trend clearly seems to be toward universalism, while on the domestic front there seems to be an increasing swing toward particularism. Taking a closer look at this paradoxical situation may help to illuminate the question of multiculturalism and democracy.

The most important international political development of the past two decades has been the global resurgence of democracy. The courageous efforts of democratic movements have brought down a host of dictatorial governments around the world - a range of brutal and squalid tyrannies including the right-wing military regimes of Latin America, the one-party states of Africa, and of course communist totalitarianism in Eastern Europe and the former Soviet Union. The success of these democratic movements has both reflected and helped further to promote the growing worldwide acceptance of certain basic principles of liberal democracy — notably, the protection of individual rights and civil liberties and the right of people to choose their governments through free and fair elections.

Now it is true that recent events have demonstrated that building workable and durable democracies is much more complex and in some ways much harder than toppling dictatorships. It is also true that with the fall of authoritarian regimes there has been a marked upsurge in ethnic strife, most 
dramatically illustrated by the former Yugoslavia. Yet it nonetheless remains clear that the principles (if not the practice) of liberal democracy today enjoy an unparalleled global ascendancy.

Prior to their revival during the past decade, these very same principles had gone into eclipse in much of the world. In part, this was owing to the impact of a Marxist critique that disparaged liberal democratic regimes and institutions as embodying merely "formal" or "bourgeois" democracy that served as a cover for class oppression. But perhaps even more damaging was the view that the principles of liberal democracy were distinctively "Western," not simply in their origins, but in their very essence. Hence there were no valid grounds for seeking to apply them in non-Western parts of the world, especially in countries that had recently thrown off the yoke of colonialism.

The global democratic resurgence of our time would not have been possible unless men and women throughout much of the non-Western world had emphatically rejected this view. Time and again I have heard from the lips and read from the pens of people from Asia and Africa (not to mention Latin America and Eastern Europe) that they had as much right as any North American or West European to appeal to universal principles of liberal democracy. Not only that, but that they regarded it as demeaning and even racist for Westerners to imply that any lesser standards should be applied to their countries.

Let me present some examples drawn solely from articles for the publication that I edit, the Journal of Democracy. Here are the words of Burmese democratic leader and Nobel Peace Prize recipient Aung San Suu Kyi:

Opponents of the movement for democracy in Burma have sought to undermine it by ... condemning the basic tenets of democracy as un-Burmese. There is nothing new in Third World governments seeking to justify and perpetuate authoritarian rule by denouncing liberal democratic principles as alien.... It was predictable that as soon as the issue of human rights became an integral part of the movement for democracy, the official media would start ridiculing and condemning the whole concept of human rights, dubbing it a Western artifact alien to traditional values... [But it] is a puzzlement to the Burmese how concepts which recognize the inherent dignity and the equal and inalienable rights of human beings ... can be inimical to indigenous values.... The proposition that the Burmese are not fit to enjoy as many rights and privileges as the citizens of democratic countries is insulting.'

Next, I quote from a talk by Wuer Kaixi, one of the two principal leaders of the Chinese student demonstrations in Tiananmen Square: 
In the course of the prodemocracy movement, many of my fellow students, friends and comrades, along with doctors, nurses, and men and women from all walks of life, were killed in Tiananmen Square and on Changan Avenue in Beijing. ... What were they demanding? It was very simple: freedom, democracy, human rights, and the rule of law. And a true republic. In name, China is called a "People's Republic," but even after the revolution initiated by Sun Yatsen we have continued to be governed by a series of dynasties. These feudal, imperial rulers have denied the Chinese people their natural and fundamental human rights and freedoms. ${ }^{2}$

Africans seem particularly incensed at the notion that they might somehow be exempted from adherence to liberal democratic principles. Peter Anyang' Nyong'o, a Kenyan who is secretary-general of the African Political Science Association, states:

Many Westerners ... think that Africans are basically backward and cannot be judged on the basis of any universal standard. From our point of view, however, human rights are universal; the right to be ruled democratically is enshrined in the UN Charter and the Universal Declaration of Human Rights. All human beings are born equal and are endowed by their Creator with basic rights that belong to them as human beings, and not as people of this or that color, continent, sex, nationality, or religion. ${ }^{3}$

Here is a quote from an article by journalist Bona Malwal, a southern Sudanese now in exile from the Islamic fundamentalist dictatorship that rules his country:

Among the obstacles that Sudanese democrats must overcome, one is particularly disheartening. This is the attitude of condescension that some politicians, public officials, and other elites in the West take towards democracy in the developing world. ... Just as the people of the Sudan reject the notion that democracy is suitable only for the developed, as opposed to the developing world, so should the people of the developed world help them by standing firm for democratic principles [and] refusing to deal in double standards. ${ }^{4}$

Finally, let me cite an article by Cameroonian political scientist Paul Ntungwe Ndue, who rails against the notion that

human rights are chimerical abstractions; culture, race, or nationality is what really counts. In the case of Africa, such rights can be trumped easily by tribal customs and the cult of the chief.... These quite simply racist doctrines, coined in order to justify dictatorships, long misled even honest people.... In 
reality, this dangerous illusion merely makes possible the colonization of Africa by other means. The generation of Africans that is now calling for democratic pluralism has realized this. There is no such thing as white, black, yellow, Eastern, or Western human rights; there are universal human rights, applicable to human beings as such by virtue of their universal characteristics. It is because of the universality of these rights that one part of the world feels involved when they are violated elsewhere. Their recognition and safeguarding is a matter of urgency for Africa. ${ }^{5}$

There has been enormous sympathy in the United States for the cause of international human rights and for the recent triumphs of democracy abroad. Yet so far as I can discern, the universalistic outlook of these Third World democrats has had virtually no resonance in our domestic debate over multiculturalism. Indeed, my guess is that many of the same people who regard themselves as supporters of a vigorous human rights policy abroadand are horrified by ethnic conflict in the postcommunist countries-also favor the trend toward multiculturalism at home.

Whether there is a real contradiction here depends, of course, on what one means by multiculturalism. If it amounts to no more than a recognition or even celebration of cultural pluralism, then it obviously poses no fundamental challenge to liberal democracy. My children get a steady diet of this brand of multiculturalism in their schools-ethnic festivals, lessons in the contributions made by various groups, and the like. Even this benign approach can be susceptible to abuses, ranging from distortions of the historical record to the "crowding out" from the curriculum of serious instruction about America's democratic political institutions. But in principle there is certainly no incompatibility and arguably even some mutual reinforcement between democracy and this sort of cultural pluralism.

There also seems to be another, more radical strain of multiculturalism, however, which holds that any principles that lay a claim to universality are merely instruments that some cultural groups use to exert dominance over others. According to this view, the injustices that have been visited upon various minorities during the course of American history are evidence not of America's failure to live up to its democratic principles in practice, but of the spurious or defective character of those principles themselves. Although this perspective typically presents itself as a defender of the marginalized and oppressed, it has always seemed to me that its attempt to "unmask" all allegedly universal moral and political principles as nothing more than rationales for domination ultimately points toward a politics of raw power. It is a 
view that would be much more congenial to the perpetrators of "ethnic cleansing" in Bosnia than to the brave and beleaguered Serbian democrats in Belgrade who criticize Milosevic and his supporters for their violation of universal democratic norms.

What strikes me most forcefully about the U.S. debate over radical multiculturalism is, to use a barbarous term, how "Americocentric" it is. My sense is that most supporters of radical multiculturalism take for granted (even as they threaten to undermine) the solidity of America's liberal democratic order and the relatively nonethnic character of the American national identity. They do not really contemplate the dangers or even envisage the possibility of setting America's various ethnic groups at one another's throats, of giving rise to a serious politics of ethnic struggle, or of turning America into a truly divided society. Even in severely divided societies democracy is not necessarily impossible, and there is a growing literature in comparative political science that explores how various electoral systems and federal arrangements can help to make it work. ${ }^{6}$ But the sad experience of democratic breakdown in such cases as Lebanon, Sri Lanka, and Nigeria's First Republic indicates the scope of the difficulty.

The relationship of ethnicity and nationalism to democracy is one of the central questions of our age, at the level of both theory and practice. I am not among those who view ethnicity and nationalism as simply atavistic expressions of particularism wholly at odds with the universalist demands of liberal democracy. To take but one example, the democratic movements in the non-Russian republics of the former Soviet Union were inevitably nationalist movements as well. Liberal democracy simply could not have worked if the former Soviet empire had remained a single political unit, any more than it could have worked in Asia and Africa if the old West European colonial empires had maintained their territorial integrity. Nationalism can take a variety of political forms, however, just as ethnicity can find political expression in many different ways. The key desideratum for democrats must be to shape nationalism and ethnicity in such a fashion that they remain compatible with liberal democracy.

On the whole, I would say that the United States has been generally successful in fashioning an American nationalism tied not to "blood and soil" but to the liberal democratic principles on which this country was founded. Despite certain "nativist" strands in our history and even in our current politics, this evolving national identity has remained largely accessible to people arriving on our shores from all over the globe. Expatriates from non-Western 
countries who have lived in both the United States and Western Europe almost invariably remark on how much easier it is for foreigners-and especially their children - to become Americans than to become Frenchmen, Englishmen, or Germans. One can be a hyphenated American without being any the less American.

In my view the pull of Americanism is strong enough, and the ethnic identities that might be arrayed against it are attenuated enough, that multiculturalism does not in itself pose a serious threat to American society. The power and prestige of radical multiculturalism in our universities, however, is a worrisome sign that Americans may be experiencing an accelerating loss of faith in the soundness of our own liberal democratic principles-at the very moment when they are being embraced by nations around the world.

It is striking that the democratic voices from the developing world I cited earlier frequently invoke not merely contemporary United Nations documents proclaiming universal human rights but also the language of the classic eighteenth-century American formulations of these ideas. In fact, today one is far more likely to find such terms as "natural" or "inalienable" rights used by democratic thinkers or activists from Africa, Asia, or the former Soviet Union than by those from the West. Today, as people from a multitude of cultures throughout the world are expressing their support for America's liberal democratic principles, it is not only ironic but also deeply troubling that the intellectual foundations of those principles are being eroded here at home.

\section{Notes}

1. Aung San Suu Kyi, “In Quest of Democracy," Journal of Democracy 3 (January 1992): $5,10-11$.

2. Wuer Kaixi, "After the Massacre," Journal of Democracy 1 (Winter 1990): 7.

3. Peter Anyang' Nyong'o, "Africa: The Failure of One-Party Rule," Journal of Democracy 3 (January 1992): 94.

4. Bona Malwal, "The Agony of the Sudan," Journal of Democracy 1 (Spring 1990): 77, 86.

5. Paul Ntungwe Ndue, “Africa's Turn Toward Pluralism," Journal of Democracy 5 (January 1994): 52-53.

6. See, for example, Larry Diamond and Marc F. Plattner, eds., Nationalism, Ethnic Conflict, and Democracy (Baltimore: Johns Hopkins University Press, 1994).

7. See Diamond and Plattner. 


\section{Part III}

Multiculturalism and Civic Education 
This page intentionally left blank 


\title{
Chapter 11
}

\section{Civic Education in a Changing Society}

\author{
Linda Chavez
}

The face of America is changing. It's becoming more diverse and complex than at any time in our history. We're no longer a white-and-black society struggling to integrate two major groups of people who have been in this country for nearly four hundred years, but a multiracial and multiethnic society in which newcomers arrive in record numbers every day. The 1980 s will be remembered as a period of one of the highest levels of immigration in our nation's history. Some ten million persons immigrated to the United States in that decade, a number as great as that of the previous peak decade, 1900 to $1910 .^{1}$ The 1990 s will probably see even more arrivals.

Unlike the immigrants of the early part of this century, who were primarily from Europe, the great bulk of today's immigrants - about 80 percentcome from Asia and Latin America. ${ }^{2}$ Much has been made of this phenomenon, and many who favor restricting immigration suggest that these new Asian and Latin immigrants will be less successfully absorbed into the fabric of American society. "I know that earlier large waves of immigrants didn't 'overturn' America," says former Colorado governor Richard Lamm, "but there are ... reasons to believe that today's migration is different from earlier flows."

But, in fact, when we look at one of these groups, we find that most Hispanics are assimilating into the social, educational, economic, and language norms of this society despite the image of Hispanics portrayed in the media and perpetuated by Hispanic leaders. A few facts:

- Mexican-origin men have a higher labor-force participation rate than non-Hispanic males. ${ }^{4}$

- U.S.-born Hispanics have rapidly moved into the middle class. The earnings of Mexican American men are now roughly 80 percent of those of non-Hispanic white men. ${ }^{5}$

- Mexican American men earn about 93 percent of the earnings of nonHispanic white males with comparable education. ${ }^{6}$ 
- Most differences in earnings between Hispanics and non-Hispanics can be explained by educational differences between the two groups; but at the secondary school level, young Mexican Americans are closing the gap with their non-Hispanic peers. Seventy-eight percent of second-generation Mexican American men aged twenty-five to thirty-four have completed twelve years of school or more, compared with approximately 90 percent of comparable non-Hispanic whites.?

- English proficiency is also key to earnings among Hispanics, but here, too, conventional wisdom about Hispanics is mostly invalid. The overwhelming majority of U.S.-born Hispanics are English-dominant, and one-half of all third-generation Mexican Americans-like most other American ethnics—speak only one language: English.

- What's more, Hispanics, with the exception of Puerto Ricans, have marriage rates comparable to those of non-Hispanic whites. Mexican-origin and Cuban Hispanics are more likely to live in married-couple households than the general population, and almost half own their own homes. ${ }^{8}$

If these facts come as a surprise, it's largely because most of the analysis of Hispanics fails to note that nearly half of the adult Hispanic population is foreign-born. ${ }^{9}$ And like new immigrants of the past, Hispanic immigrants will take at least one generation to move up the economic ladder and into the cultural mainstream.

Perhaps a little history is in order here. The current period is not the only time we have viewed new immigrants with distrust and suspicion. We tend to forget that Italians, Greeks, Jews, Poles, and others - whom some people lump together as "Europeans"-were considered alien to the white Americans of the early twentieth century, most of whom were of British, German, or Scandinavian descent. Anyone who believes that immigrants of an earlier day lived in halcyon times of tolerance and acceptance should read through the reports of the 1921 Dillingham Commission, which in 1924 ultimately recommended a quota system to keep out southern and eastern European immigrants and Asians. ${ }^{10}$

Despite these problems, most of those who came here found the struggle worth the effort. And these groups did, by and large, succeed in America. Today, the many different European immigrant groups are virtually indistinguishable from each other on measures of earnings, status, and education. Even Chinese and Japanese Americans, who endured much greater discrimination than southern and eastern Europeans, have done exceedingly 
well and outperformed most other groups on all indicators of social and economic success. But it took three generations for most of these groups to achieve this status. Italian Americans, for example, arrived at the same average educational attainment as other Americans only in 1970 - some sixty years after the peak of their immigration to the United States. ${ }^{11}$

Is it possible simply to mimic what we did in the past in treating this generation of newcomers? No. Let me concede that we did a great deal of wrong in the past, and immigrants succeeded in spite of, not because of, our mistakes. It would be neither compassionate nor legal to return to a system in which we put non-English-speaking children into the public school classrooms in which the instruction was entirely in English and expect those children to "sink or swim." The United States Supreme Court in 1974 declared this approach in violation of our civil rights laws. ${ }^{12}$ Nor should we hark back to the "good old days" when Anglo conformity was the sole acceptable cultural model. But in trying to right these wrongs, we should take care not to reverse ourselves 180 degrees by attempting to educate each group of immigrant children in their own native language and inculcate them in their own native culture. There is something wrong when two-thirds of children from Spanish-speaking homes are taught to read in Spanish when they enter first grade in American public schools and three-fourths are given Spanish oral language development. If we insist on separate language instruction for all immigrant children - who speak more than 120 different languages in New York City alone ${ }^{13}$ - we will close the door on integration, divide ourselves along cultural and linguistic lines, and thereby perpetuate inequalities rather than eradicate them. The proponents of multicultural education are often so obsessed with the excesses of Anglo conformity that they fail to see the benefits of a shared, common culture-not entirely white, Anglo-Saxon, or Protestant-but common nonetheless. And they fail to see the dangers in substituting one orthodoxy with another, no less rigid.

The more diverse we become racially and ethnically, the more important it is that we learn to tolerate differences - and also to celebrate what we all have in common. Whether we came to the United States voluntarily or involuntarily, we all choose to live here now. And more people want to live here than anywhere else in the world. No other country accepts as many immigrants as we do. Surely, even those who criticize our so-called Eurocentric society must admit that it has something to offer or there would not be such long lines of those waiting to get in-very few of them European, by the way. What do we have that these Mexicans, Cambodians, Ethiopians, Filipinos, 
and others want? Two things primarily: economic opportunity and political freedom. The two, by the way, go hand in hand, and it is our legal and political institutions that protect both. Now it so happens that those political institutions did not, in fact, develop in Asia or Latin America or Africa or even throughout most of Europe. It happens that the framework for our political institutions comes from England. The basis for American jurisprudence comes from English common law-not Spanish adaptations of Roman law that governed most of Latin America, or from the legendary rulers of China or from the Hsia Dynasty or from Confucianism, or from the Ghanian Empire, the Kush state in Nubia, or from Mali. That is not to say that these others are not important civilizations deserving recognition in their own right, but it is to acknowledge the special importance to our particular political and legal system of the Magna Carta, habeas corpus, and trial by jury, all of which were handed down directly from England. Of course, not all of these concepts were totally indigenous to England; King Henry II adapted from the Franks the system of trial by jury to replace the oath, the ordeal, and the duel, which were used in both criminal and civil cases until the twelfth century.

In our zeal to tell the stories of other civilizations, to include the history of those whose ancestors came from places other than England, we should not attempt to rewrite the history of our own founding and our political antecedents. Nor should we blush at the thought that this history now belongs to children who come from Mexico, Vietnam, and Ghana, or whose parents came from these countries. These children are now American children, and this is their political inheritance as much as it is the inheritance of the child of Italian or Greek or Russian roots. As we hasten to promote diversity, we often forget that what makes this country unique in the world is that we have forged an identity as a people even though most of us share very little in common in terms of our personal histories. There is nothing wrong with holding onto personal history, but - given the incredible diversity of the country as a whole-it becomes increasingly difficult to expect the state to try to pass on that sense of personal history to each and every group. The most that can be expected, I think, is that we make sure that we recognize the contributions each group-once here-has made to the common history of this nation.

Is it possible to study the individual culture of the ancestors of each group represented in America? That depends on how superficial we're willing to be. We could develop a dictionary of cultural literacy of every major group and teach children to memorize a few facts and dates about each. Given our current success with children's learning to locate Arkansas on a map of the United States and China on a map of the world, or to tell in what half a cen- 
tury the Civil War was fought, or to name more than four past presidents of the United States, it seems doubtful that such a project would carry a lasting benefit. But there are other problems as well. Who decides what represents the "history" of each group? Take Hispanic children, for example. What do we teach them about the Maya, Aztecs, and Incas? They are all important civilizations, but relatively few Hispanics in the United States actually descend from them. And what about the history of Spain? Will Hispanic youngsters read Cervantes and Lope de Vega, or something else?

The problem is no less complicated when it comes to African Americans. In the name of multicultural education, many school systems have adopted an Afrocentric curriculum that mostly focuses on the contributions of ancient Egypt. There is no question about the fact that Egypt is on the continent of Africa, but that is about all traditional Egyptologists and Afrocentrists can agree upon. Is Egypt better understood as a part of the broader thalassic culture of the Mediterranean, which also includes the Middle East and southern Europe? The Sahara, which separates Egypt from the central and southern portions of the African continent, today remains a powerful cultural barrier. Are we to assume it was less so in the past? These issues are rarely addressed by Afrocentric curricula.

So if we cannot - and perhaps should not - try to teach each group its own individual history through multiple ethnocentric curricula, how do we try to deal with this increasingly diverse student population?

1. Black, Hispanic, Asian, and American Indian children need the same basic skills that we take for granted that white children need. This is an obvious point, but one that seems occasionally forgotten when we discuss multicultural education. All children in American public schools need to be taught to read, write, and speak standard English well. Their ability to master these skills will affect their life chances more than virtually anything else they learn—or fail to learn-in school.

2. They need to be taught the basic math and science that will enable them to function in an increasingly complex technological society.

3. They need a broad understanding of our form of government and its institutions. We live in a country in which we enjoy great freedom, but we also live in a country in which people are highly apathetic. If we hope to preserve democracy, our young people must develop a better appreciation for our heritage and be committed to preserving it. Somewhere along the way we have 
become reticent about instilling in our young an appreciation for democracy. If we expect to preserve our democratic way of life, we had better begin to develop that appreciation once again. And that means emphasizing the duties and responsibilities that go along with good citizenship.

4. We need to teach our children the history of this nation. Here, we sometimes failed in the past to include the contributions made by all the groups that compose this nation. While we should not shy away from teaching the essentially English antecedents of our political and legal institutions, neither should we forget that many who built this nation were not English, white, or male. There are many excellent histories to consult about the contribution of African Americans: W. E. B. DuBois, John Hope Franklin, Carter Woodson, to name only three. There are fewer familiar texts to consult on the contributions of Mexican Americans, Puerto Ricans, Chinese Americans, and other Asians, but two good books on the Latinos are Hispanics in the United States by Harry Pachon and Joan Moore ${ }^{14}$ and Puerto Rican Americans by Father Joseph Fitzpatrick. ${ }^{15}$ Both are short but comprehensive.

5. All American children need a better understanding of the world in which we live, an understanding that includes something of the history of other nations. They need a grounding in geography, which, if taught well, will also teach them why nations developed as they did. Rivers, seas, terrain, and climate are all important to the development of culture. Of course, learning the language of another country is the best way to develop a real depth of understanding in that culture, and I hope we do not ignore developing second-language proficiency in all of our students. In this respect, immigrant children have a real advantage.

These recommendations are not exhaustive. Nor are they geared only to the child who comes from a nonwhite, non-European background. These recommendations are suited for all of our children.

The American public school system was created on the premise that it would be a common school, one for all children. It has not always lived up to that ideal-certainly not before 1954-but that does not mean we should abandon the ideal. The face of America is changing, but we should not give up on the idea that we are one people and one nation.

Even under this regime there remains a place for the preservation of language and culture for new immigrants or others who wish to retain aspects 
of their former traditions. Some would have us believe that assimilation means every group must lose what makes it unique as it swirls about in an indifferent melting pot's colorless alloy. But, of course, this is not what has happened. As a trip into the heart of any American city will reveal, ethnic communities are alive and well, even as their inhabitants enjoy the fruits of social, political, and economic integration. The question is not whether any group has a right to maintain its language, culture, and traditions, but rather whose responsibility it is to do so: the individual's or the government's? This is the center of the multiculturalism debate.

If Hispanics, Koreans, Jews, Greeks, or the members of any other group wish to maintain their individual and unique cultures, languages, or traditions, it must be up to them to do so. Indeed, many groups have been quite successful in preserving their native cultures in the United States. Chinese parents often send their children to Saturday school to learn Cantonese or Mandarin and the history of their ancestors. Jewish children frequently attend Hebrew classes and receive religious instruction that teaches them the tenets of their faith and the history of their people. Greek Americans are among the most successful of any group in preserving their language in the United States; according to the 1980 census, a majority of Greek Americans say they still speak Greek in their homes at least occasionally.

Hispanics who wish to maintain their native language and culture should follow the examples of their fellow ethnic Americans. Frankly, given the tremendous diversity within the Hispanic community, the only successful way for each group to ensure that its members know its history and traditions is to undertake that education itself. If government assumes the responsibility, it is likely to amalgamate and homogenize in ways that make the original culture virtually indecipherable. The government, after all, is capable of lumping all 22 million Hispanics in this country into a single category that manages to include Cakchikel Indians from Guatemala, mestizos from Mexico, the descendants of Italian immigrants from Argentina, Japanese immigrants from Peru, Spaniards from Europe, and the descendants of colonists who settled the Southwest nearly four hundred years ago. Wouldn't it be better to entrust each of these very different groups with the responsibility of maintaining its own traditions without the interference - or assistance- of the government? The overwhelming majority of immigrants think so. They believe that it is the family's duty, not the government's, to help their children maintain their native language. ${ }^{16}$

Some critics warn that the United States is in danger of fragmenting into competing racial and ethnic groups. Nonetheless, I remain optimistic that 
we can - if we commit ourselves - successfully integrate the more than 70 million blacks, Hispanics, Asians, and American Indians into our society. That we can create a new unum out of the many here and the many more who will come. But to do so will require the cooperation of us all-those who have been here for generations as well as those who are arriving each day. It will require that each of us recognize the covenant that exists between the old and the new; that we respect the rights of individuals to maintain what is unique in their ancestral heritages; but that we understand that our future lies in forging a common identity of shared values and beliefs essential to the democratic ideal.

\section{Notes}

1. John J. Miller and Stephen Moore, The Index of Leading Immigration Indicators (Washington, D.C.: The Center for Equal Opportunity, 1995), 2.

2. Miller and Moore, 7.

3. Richard D. Lamm and Gary Imhoff, The Immigration Time Bomb: The Fragmenting of America (New York: Truman Talley Books, 1985), 77.

4. U.S. Census, The Hispanic Population in the United States (1990).

5. Linda Chavez, Out of the Barrio: Toward a New Politics of Hispanic Assimilation (New York: Basic Books, 1991), 112.

6. Chavez, 112.

7. Chavez, 113.

8. U.S. Census, The Hispanic Population in the United States (1992).

9. U.S. Census Bureau, 1990 Census, CP-3-3, "Persons of Hispanic Origin" (1990).

10. John Higham, Strangers in the Land: Patterns of American Nativism 1860-1925 (New York: Atheneum, 1973), 310.

11. Commission on Civil Rights, The Economic Status of Americans of Southern and Eastern Ancestry (Washington, D.C.: GPO, 1986).

12. Lau v. Nichols, 414 U.S. 563 (1974).

13. John J. Miller, "The Rest of the 'Rainbow' Curriculum," Wall Street Journal, February $10,1993$.

14. Joan W. Moore and Harry Pachon, Hispanics in the United States (Englewood Cliffs, N.J.: Prentice-Hall, 1985).

15. Joseph P. Fitzpatrick, Puerto Rican Americans: The Meaning of Migration to the Mainland (Englewood Cliffs, N.J.: Prentice-Hall, 1987).

16. Linda Chavez, “One Nation, One Common Language," Reader's Digest, August 1995. 


\title{
Chapter 12
}

\section{Multiculturalism and Civic Education}

\author{
Lorraine Pangle
}

Multicultural education is a new attempt to solve one of humanity's oldest social problems, the problem of ethnic division and conflict. The idea of multiculturalism was first popularized in Canada in the 1960s, as a result of rising tensions between Quebec nationalists and the English-speaking majority. In response to French discontent, the Canadian federal government began considering measures to strengthen the official status of the French language and culture, so as to put the two "founding races" on a more equal footing. This proposal, in turn, sparked a concern among Ukrainian Canadians and other ethnic groups that their own languages and cultures were being relegated to third-class status. Prime Minister Pierre Trudeau thereupon worked out the compromise of "multiculturalism within a bilingual framework," a policy which recognizes and encourages cultural diversity as a desirable feature of Canadian society. Official multiculturalism in Canada has included the promotion of bilingualism throughout the country, government support for the cultural activities of ethnic minorities, direct efforts to combat racism, and most importantly, programs of multicultural education that attempt to give all students a positive regard for the various ethnic groups that make up Canadian society.

The United States, having no such deep-seated language divisions as Canada, has not been pushed into an official policy of multiculturalism. Many American educators, however, have embraced multicultural education for the same reasons that recommend it to their northern neighbors. Both countries have large and diverse minority populations; both have found their ethnic diversity to be a source of conflict, and yet in both there is increasing doubt as to the viability or justice of old expectations that minorities should simply assimilate to the language and customs of the majority. Proponents of a new "cultural pluralism" argue that ethnicity is important to everyone's identity and that a fair and humane society must respect and even actively foster ethnic loyalties. Influential multicultural curricula, such as that of $\mathrm{New}$ 
York State, emphasize the positive value of having a variety of cultures within the United States, call for a new "cultural democracy," and even assert a "right" to cultural diversity. ${ }^{1}$

\section{The New Civics and Its Dangers}

American advocates of multicultural education want to transform the entire school curriculum to make it more inclusive and less biased, but their central interest is naturally the social studies program, and especially the teaching of history. They point out a number of flaws in history programs as they have traditionally been taught in the United States. American schools have always neglected the study of other parts of the world, and until recently, they have tended to teach American history in a somewhat self-congratulatory spirit. Noah Webster set the tone for American schoolbooks with the stream of influential spellers and readers he began producing in the 1780s. He filled his books with American content and worked to instill in students a pride in their virtuous republic, contrasting it with the decadence of monarchic Europe. As he argued in his first speller, "Europe is grown old in folly, corruption, and tyranny - in that country laws are perverted, manners are licentious, literature is declining and human nature debased. For America in her infancy to adopt the present maxims of the old world, would be to stamp the wrinkles of decrepit age upon the bloom of youth and to plant the seeds of decay in a vigorous constitution." ${ }^{\prime 2}$ In the early nineteenth century, Parson Weems began weaving about our national heroes such pious fictions as the story of George Washington and the cherry tree, which were soon taken up and immortalized by the McGuffy Readers. With the best of intentions, such stories rob history of life by presenting great leaders as less human, less complex, and hence less interesting than they really were. Traditional American textbooks have been criticized, with some justice, for presenting our history as chiefly a series of triumphs, for downplaying both darker incidents and controversial interpretations, and for telling the story from the point of view of white settlers and white slaveholders or liberators, neglecting the viewpoints of American Indians, slaves, and immigrants.

These criticisms, if taken seriously, suggest that American students need a history and civics program that is more objective, more probing, and above all less provincial than the courses their parents received. The criticisms would seem to call for a curriculum that would offer students not only a richer perspective on American history, but also an encounter with radically 
different outlooks and ways of life and a confrontation with controversial arguments about many issues. This could be accomplished through a sequence of in-depth studies of cultures or civilizations or regimes from many parts of the world and historical epochs. It could lead to a questioning and a reexamination of the assumptions and beliefs students have picked up from contemporary American society. To that extent, it might prove dangerous, and have more of a corrosive than a constructive effect on their political and moral beliefs. But if teachers took account of this danger and worked to make as strong a case as possible for the American principles and way of life that would be coming under scrutiny, the result could be an excellent civic education that would be politically responsible and liberating at the same time.

When one looks at the specific proposals and guidelines for multicultural education that have been produced in both the United States and Canada, however, one is struck by the extent to which they perpetuate precisely the aspects of the old civics education that critics find objectionable. In particular, it is surprising how provincial they still are, and how few issues they explore. Ontario's recent guideline, The Common Curriculum, is quite typical of programs on both sides of the border. The focus is entirely on the students' own country and the ethnic groups within it. Students are to study the contributions of each group to Canadian society, learn that cultural diversity is good, learn about the evils of racism, and study the ways in which everyone is formed willy-nilly by birth, class, culture, geography, race, and discrimination. Little attention is given either to the beliefs and principles that all Canadians hold in common or to the truly deep differences between Canada and many of the societies from which its immigrants have come. The guidelines for New York State's multicultural geography and history program are similarly narrow in focus. Although students are required to take a smattering of world history, no area except the United States is studied in any depth, and the central concepts around which American history is to be organized are virtually all related to ethnicity, race, and equity. The guidelines for American history pay no attention to, for example, the structure of the federal government, religion, the significance of the frontier, or international relations. The goal of these and similar guidelines in other states is not to provide a broad-based civic education or to expand students' minds through an encounter with a rich variety of cultures, historical figures, and interesting historical controversies. Rather, the goal is to solve specific social problems associated with ethnicity, and sometimes also with gender and disability: 
to end inequities by promoting toleration in the majority and enhanced selfesteem for "marginalized" groups. ${ }^{3}$

Such social studies as social therapy is, I believe, a dangerous distraction from the real business of teaching and learning. If we conceive of multicultural education as a device for eradicating discrimination and inequities by instilling specific, officially approved feelings and beliefs, it can do significant harm. If, on the other hand, we accept it as a needed reminder that we must broaden and deepen students' study of the world and of genuinely different points of view, a multicultural approach can do much to revitalize American education and can promote social harmony at the same time.

Unfortunately, advocates of multicultural education have for the most part produced programs at least as dogmatic and manipulative as the old ones they criticize. Their guidelines place too much emphasis on molding the feelings, and give too little attention to provoking serious thought. One state, Pennsylvania, states explicitly in its curriculum guidelines that achieving the specified graduation outcomes "does not require students to hold or express particular attitudes, values, or beliefs," but such disclaimers are rare in multicultural programs. More typical are Iowa's instructional objectives, which stipulate that students shall "demonstrate understanding that cultural differences do not imply cultural deficiencies," shall "analyze U.S. diversity as a source of vitality, richness, and strength," shall "understand that no individual or group is inherently superior or inferior," and shall "demonstrate respect for physical and cultural differences by modeling nonsexist, culturally sensitive language and interaction patterns." ${ }^{\prime 4}$

Most interesting is the goal that appears in virtually all guidelines for multicultural education, that of persuading students that cultural diversity is good. This assertion is less than self-evident, as the New York Social Studies Review and Development Committee concedes at the very outset of One Nation, Many Peoples: "Certainly, contemporary trends toward separation and dissolution in such disparate countries as the Soviet Union, South Africa, Canada, Yugoslavia, Spain, and the United Kingdom remind us that different ethnic and racial groups have often had extraordinary difficulty remaining together in nation-states." Laying these grim object lessons before us, the authors then simply assert without evidence that diversity is the source of our national strength. There is no doubt that the colorful appeal of cities like New York and San Francisco depends largely upon their ethnic diversity, and American cuisine was indisputably dull before the proliferation of ethnic restaurants, but such things can hardly be put in the scales 
against the threat of national dissolution. Multicultural advocates routinely assert that ethnic diversity provides us with a multiplicity of approaches to solving problems, but since they do not give examples of problems that have proved insoluble without the aid of some special ethnic point of view, this claim is hard to assess. Individuals from every corner of the earth certainly have made great contributions to American society, but that is not what is at issue here. Americans from many cultures have also derived strength and comfort from their separate traditions, but it is not clear that they are happier or contribute more to the country than their assimilated descendants who view themselves simply as Americans. The most serious reason for the argument that cultural diversity as such is a source of national strength appears in the next sentence of the New York committee's report: "If the United States is to continue to prosper in the 21 st century, then all of its citizens, whatever their race or ethnicity, must believe that they and their ancestors have shared in the building of the country and have a stake in its success." Cultural diversity must be celebrated as a positive good, it seems, because without such a celebration, not all citizens will feel a sense of belonging and dedication to America.

\section{Ethnic Pride and Self-Esteem}

In place of the old efforts to mold students' feelings by encouraging a patriotic devotion to national unity, we now have attempts to encourage feelings of ethnic solidarity and an attachment to diversity. Is it appropriate for schools to engage in either national or ethnic boosterism, in order to cultivate feelings of pride and belonging? The dangers of nationalism have been as evident in this century as the dangers of ethnic strife, and of course the two are closely related. It would nevertheless be unwise to try to root out or transcend national loyalties altogether: patriotic feeling has been an integral part of every healthy society, and the current American doctrine that our country is no better than others (or indeed a bit worse) is more likely to produce an apathetic disaffection from politics than a genuine love and concern for all of humanity. Patriotism can unify a country and draw citizens out of their private affairs into constructive efforts on the public behalf and noble acts of sacrifice. In the best case, patriotism gives citizens a sense that they belong to something important that is greater than themselves, a sense of what they must live up to, and a hope that indeed they can live up to standards set by others of their own kind who have gone before. Moreover, 
American patriotism is less divisive than, say, the patriotism of the Serbs, because it does not depend upon the accidents of birth. What we take pride in, above all, is a set of principles that can potentially be accepted and implemented anywhere. To be an American means to be an immigrant or the descendant of immigrants. Hence our ability to admire Benjamin Franklin or Frederick Douglass and to count them as our own does not depend upon our being related to them by blood, or having ancestors who lived in the same country with them, or even knowing where our ancestors were when these men were alive.

Advocates of multiculturalism, however, tend to assume that the accidents of birth are all-important for everyone's sense of identity. They seek to give every child, or at least every nonwhite child, the same pride in his or her ethnic group that traditional American texts have endeavored to give American students in their nation. Arguing that self-esteem is an essential condition for success and that a positive attitude toward the group one was born into is an essential condition for self-esteem, these advocates seek to present minority groups as favorably as possible. This is why, although painstaking efforts have been made to remove the biases from American history texts, the controversy over these books rages hotter than ever. Representatives of various minorities, joined by representatives of women, homosexuals, and the handicapped, charge that their own groups are inadequately represented or not depicted in a sufficiently positive light. ${ }^{6}$

The project of rewriting history has been carried furthest by Molefi Kete Asante, Leonard Jeffries, and other proponents of an "Afrocentric" curriculum for black youth. These activists argue that American culture is, root and branch, Anglo-Saxon or Eurocentric culture, forgetting the American founders' deliberate efforts to take a critical distance from Europe and forge a new country with new principles. They teach that blacks must find their own, Afrocentric culture, suited to African modes of thinking and feeling, and that blacks can never be educated effectively by white teachers. An influential series of "African American Baseline Essays," edited by Asa Hilliard, has been used in Portland and other cities to teach black children that Africa is the true source of civilization and of Western science, medicine, mathematics, and democracy. They maintain that the Greeks "stole" philosophy from the ancient Egyptians, and that the Europeans have taken credit for it in a massive conspiracy. In a similar vein, Jeffries teaches that in contrast to the warm, humanistic Africans, Europeans are "cold, individualistic, materialistic, and aggressive 'ice people." "' Quite apart from the unsubstantiated claims 
of the Afrocentrists, which have been critiqued by black and white scholars alike, such teachings add fuel to the very fire that multiculturalism was originally intended to quench. One does not put an end to bigotry by turning it on its head, or heal race relations by focusing children's minds on the question of which race is responsible for more good or more evil in the world.

Even when ethnic cheerleading is not taken to such lengths as it is in the African American Baseline Essays, direct efforts to change students' feelings about themselves are a central feature of most multicultural education proposals. In the blunt words of a 1989 New York State task force, the social studies curriculum should be revised in ways that will provide "children from Native American, Puerto Rican/Latino, Asian American, and African cultures" with "higher self-esteem and self-respect, while children from European cultures will have a less arrogant perspective." Other plans are rather more generous in attempting to nurture the self-esteem of everyone. As one of Iowa's policy statements puts it, "It is important that all students see themselves positively reflected in their curriculum, regardless of their sex, race, cultural background or disability. Students who do not, often feel alienated from the educational process and may soon question their own worth." Iowa's guidelines therefore mandate, among other things, that all units of Iowa and American history must include "the contributions and perspectives of both women and men, diverse cultural/racial groups, and the disabled." One wonders how a unit on, say, the Constitutional Convention could ever be taught. Making the curriculum as objective and unbiased as possible is important for many reasons, but when specific material is included or excluded chiefly on the basis of its presumed effect upon students' self-esteem, we must question the pedagogical soundness of the selection. When students spend extensive amounts of time examining ads for bias and writing letters of protest to advertisers, sampling one another's cuisines, recounting occasions when they experienced discrimination, and clarifying their feelings about their ancestors, we must wonder what more substantive lessons are being displaced. ${ }^{8}$

Educators routinely assume that self-esteem is an essential prerequisite for learning, and a tremendous amount of what they do is premised upon this belief, but in fact it is not well supported by empirical research. Studies have generally but by no means consistently found some correlation between self-esteem and academic achievement, but there is substantial evidence that achievement is more of a cause than an effect. Brent Bridgeman and Virginia Shipman have reported that the self-esteem of preschool children tends to 
be uniformly high, and unrelated to intelligence, whereas by grade three, children's self-esteem shows much more variation and is more strongly correlated with academic achievement. They conclude that the self-esteem of low-achieving students has fallen as a result of their difficulties in school. A study by Edward Kifer shows likewise that the self-esteem of children diverges over time, and reveals an especially strong correlation with academic achievement in children who have established a prolonged pattern of high or low achievement. Apparently it is the repeated experience of success or failure that tends to create a highly positive or negative self-image. Rubin, Dorle, and Sandridge conclude that "nowhere has it been convincingly demonstrated that raising self-esteem will lead to greater academic achievement," although scattered researchers propose this on the basis of the observed correlations. ${ }^{9}$

Even if self-esteem is more the result than the cause of achievement for students in general, however, the case may be different with minorities, for advocates of multicultural education argue that minority students' experience of exclusion and stigmatization has affected their self-esteem in particularly insidious ways. Yet it is here that research results are most surprising. Among black students, at any rate, studies have shown that there is no significant relationship between overall self-esteem and academic achievement. Despite the fact that they do more poorly in school on average than white students, blacks turn out to have equal or higher levels of self-esteem. Finally, researchers have found that high individual self-esteem among them is not related to levels of black pride. All of this casts serious doubt on the assumption of multicultural education proponents in general and Afrocentrists in particular that minority children's academic difficulties stem from low selfesteem and can best be overcome through programs that help them to identify more strongly and more positively with their ethnic heritage..$^{10}$

It is even possible that a high self-esteem that is not grounded in an accurate appraisal of one's academic competence may in some ways impede learning. American students as a whole fare poorly on international mathematics assessments, yet the vast majority consider themselves to be good in math. To motivate students to work hard, every teacher must persuade them that it is important for them to know certain things that they do not know. This is always a humbling experience for a student. Humility, however, is inseparable from a recognition of what one needs, and a degree of humility can itself be quite constructive. It would of course be best if the simple desire to learn could provide sufficient motivation for a whole education, but it 
rarely if ever does. Everyone seems to need the reward of pride in one's accomplishments and an uneasiness at the prospect of doing poorly to keep oneself moving forward at moments when learning is not intrinsically fascinating. Hence having a self-esteem that is somewhat dependent on doing well at school is extremely helpful.

On the other hand, unless a student has real hope of being able to succeed at studies, it is simply too painful to acknowledge that this is important; one will do whatever one can to keep one's self-esteem from becoming dependent on academic success. Therefore, the goal of a good teacher is to create both humility and confidence, by showing students that they have work to do and that the teacher has faith in their ability to accomplish it. Studies of the teachers and teaching styles that have had the best results with disadvantaged students confirm what common sense suggests. These teachers do not try to build self-esteem unrelated to the work at hand by dwelling on the glories of their students' ancestors or telling the students that they are perfectly wonderful just as they are. Instead, they show through everything they do that academic achievement is important, that they take their students seriously and care deeply about their progress, and that they have complete faith in the students' ability to live up to high standards."

Whatever disadvantaged minority students may feel about themselves in general, this sense of hope, this confidence that they can succeed at whatever they put their minds to, seems often to be fragile in them. Here is where the multicultural approach of telling stories of people of all races and both sexes who have overcome obstacles to lead remarkable lives can be so helpful. One need not be handicapped to be inspired by Franklin D. Roosevelt's accomplishments in the face of polio, or Indian to take inspiration, as Martin Luther King, Jr., did, from Mahatma Gandhi's ideals. However, the tendency of multicultural programs to dwell on the importance of race, sex, ethnicity, and physical handicaps can undermine children's confidence in their power to shape their own lives. Although these accidental qualities are normally not subject to change, their importance to us is. Efforts to sensitize all students to these issues and to show how deeply they affect us can create a self-fulfilling analysis. It is not inevitable that black children growing up will think of themselves as black first and Americans or, say, aspiring physicians second. It is not inevitable that they will see their race and the racism of whites as a central feature of their existence and carry the kind of bitterness within them that such a perception tends to spawn. The real and ugly history of racism in the United States must of course not be papered over. It nevertheless makes a 
difference whether teachers encourage students to define themselves by accidents of birth and the problems they create or by students' own accomplishments, virtues, and aspirations. The hope of Martin Luther King, Jr., that someday all Americans might be measured not by the color of their skin, but by the content of their characters, gives eloquent expression to what has always been one of America's noblest aims. Persuading students to judge themselves this way is the first step toward fully realizing this goal.

Over the past several years, American colleges have been paying increasing attention to accidents of birth, attempting to raise the self-esteem of some students and to heighten the sensitivity of others, in hopes of ending the inequities and tensions that turn upon ethnic and sexual differences. Millions of dollars have been spent, countless workshops and mandatory orientations have been held, and whole buildings have gone up to house new cadres of campus life administrators. Yet racial and ethnic tensions have not improved and may even have gotten worse, and charges of sexual harassment proliferate by the day. Is it possible that we are encouraging people to see an affront to the essence of their beings in what was only a display of bad manners and to become more the victims of their sex or skin color rather than less so? Is it possible that, with special treatment for all sorts of groups and with such pressures upon everyone to be sensitive, we are creating a backlash?' ${ }^{12}$ It would not be surprising if programs that encourage students to delve into and express their feelings of racial animosity or to elaborate their experiences of discrimination are failing to reduce racial tensions. Bad feelings usually do not go away when we dwell upon them.

Problems between the sexes are more complex and deeply rooted, but ethnic and racial tensions may well be amenable to the same solution that the early Americans found for religious enmities. As Thomas Jefferson said, observing the various states' responses to the quarrels that arose from the country's religious diversity, "Pennsylvania and New York ... have made the happy discovery, that the way to silence religious disputes, is to take no notice of them." ${ }^{13}$ If United States governments at all levels were consistently to refuse to take any notice of race (a policy that has never been tried), racial conflict might eventually become as insignificant as religious conflict in this country. If all schools were to treat their students' racial and ethnic origins as a matter of absolutely no relevance to the business of teaching and learning, they might achieve a similar result. Students would remain free to place a high personal value on their race or ethnic origins, just as many now place on their religions, but the schools would be officially neutral on both issues. 
Such a policy, carried out in conjunction with humanities programs in which the only history studied was that of the United States and the only literature read was that of white Americans and Englishmen, surely would convey a message that the ethnic heritage of minority students was of little value. But if students were to study the history and literature of the whole world, minorities would be pressured neither to assimilate completely nor to maintain a strong sense of loyalty to their own ethnic group. All students would be encouraged to consider the world as their heritage, and to believe that they can reasonably aspire to be like anyone they choose, from either sex and from any nationality and historical epoch.

All in all, the central failing of multicultural education programs is their attempt to provide therapy for individuals' and society's perceived ills rather than to promote true education. Our society has always been tempted to try to solve its social problems by imposing new mandates on the schools. A century ago, one teacher commented, "You can't open your schoolroom door for a breath of fresh air without letting someone with a mission fall in." ${ }^{14}$ Activists hold out the alluring hope that we can make a better society simply by giving children the right attitude to every issue: to drugs, to alcohol, to the environment, to nuclear weapons, to homosexuality, to race relations. The difficulty is that new issues and problems arise every year, and the solutions are rarely as straightforward and unambiguous as reformers would wish. Before long, the slow and serious business of training minds and building character gets lost in a panoply of noisy causes. Yet our social problems remain as troubling as ever. The great irony is that many of the same reformers who are busily shaping attitudes toward the issues of the day also cheerfully assert that our children will live in a world vastly and unpredictably different from the one we know. No doubt they exaggerate, but they have a point. What is needed is not to produce "right-thinking" people, but to nurture the virtues that every individual needs and every society values, and to cultivate minds that can assess unforeseen problems with sound judgment.

\section{From Shallow Relativism to Serious Questioning}

For such an education of the hearts and minds of citizens, multicultural studies that explore other cultures as deeply and as sympathetically as possible are admirably suited. Individuals become more thoughtful, and most able to contribute to the public life of their country, when they have an outside perspective on their own society. To gain such a perspective, it is 
essential to study other cultures on their own terms, on their own ground, and in their totality. This means going beyond a study of the remnants of other cultures retained by immigrants to North America, to a historical investigation of the countries they come from. Students need to move beneath the superficial differences of dress and cuisine and artistic styles to grapple with the issues that truly define and divide cultures: different conceptions of justice or of political legitimacy or of the best way to order citizens' common life together, and different religions. Students will profit very little from multicultural studies if they attend only to the colorful elements of other cultures and are not open to the possibility that these cultures have things to teach them about the very most important questions in life. Glib talk about giving students "cross-cultural competency," or the ability to function in a variety of cultures, willfully disregards these deep and often vexing differences that make culture something more than a matter of style..$^{15}$ Thomas Jefferson exemplified a more serious multicultural approach when he tried to reform the College of William and Mary in 1779. Among other changes, he proposed dropping the missionary who was sent to teach English, arithmetic, and Christianity to the Indians, and instead sending a scholar who would study and record their languages and laws. Jefferson was persuaded that Americans could learn a great deal from the Indians both about speculative questions such as the nature of languages and the history of human migrations and about the wise ordering of society. ${ }^{16}$

Without a willingness to learn lessons from other societies about the strengths and weaknesses of our own, multicultural studies in the schools will never be more than window dressing. There will always be a few people who care about such things as the genealogy of human languages, but most of us learn so that in one way or another we may make our lives better. A good multicultural program aims at educating not philosophers but moral human beings and citizens; hence it must focus on the questions of what is just and how we ought to live. If it is responsible, it must support decency; but if it is serious, it cannot escape being controversial: true education is inherently controversial. Now a valuable part of the multicultural education movement has been the desire to move history courses away from the presentation of a single, officially sanctioned story to an encounter with multiple perspectives and conflicting interpretations. Proponents rightly argue that this approach is both more honest and more likely to stimulate interest among students. But they often assume that the multiple perspectives that matter most are not those of, say, Marxists and Augustinians and liber- 
als, but those of women and homosexuals and minorities, and that unlike the former perspectives, which can be adopted and modified through reasoned discourse, the latter cannot be understood by anyone outside the group in question. ${ }^{17}$ This is an issue of the gravest moment. Is history only a tangle of different narratives, different points of view, each of which is bound by its own horizon, determined inescapably by circumstances, and ultimately self-serving? Or do we at least potentially have access to a common and comprehensive truth, of which the different interpretations and narrative accounts are all more or less distorted, more or less illuminating fragments? If the former is the case, there is little hope for a peaceful and rational resolution of our differences, and little reason for students to be interested in listening to other perspectives. What intrigues them in a controversy is, after all, the prospect of a puzzle to be solved. But even to state the two possibilities is to show the incoherence of the former argument, in asserting the objective truth that there is no objective truth.

Despite this illogic, the denial of objective truth about history in general and moral judgments in particular is extremely common. Instilling in students a belief in cultural relativism is one of the central goals of multicultural education advocates. Tolerance and mutual respect will follow, they believe, once students see that each culture is as good as every other, and that there is no objective basis for judging any of them as deficient. The assertion of the equality of cultures and the assertion of the incommensurability of cultures are, of course, contradictory. If there is really no basis for measuring cultures or their component beliefs and customs against one another, then there are no grounds for asserting that they are equal. Each of these assertions, however, is unsustainable when taken by itself; hence multiculturalists slide continually between the two. If one maintains openly that cultures really can be weighed and measured against one another, it is a little too absurd to assert that, on some objective scale of measurement, taking all the strengths and weaknesses of each into consideration, all of the thousands of cultures the world has seen come out precisely the same. On the other hand, if one tries to argue consistently that no such measures are possible, one gives up one's moral compass. One can make no rational objection to slavery, widow burning, clitoridectomies, infanticide, or many of the other practices that have formed an integral part of various cultures. Nor can one assert anything more than an idiosyncratic preference for liberal democracy. As Mussolini saw clearly, cultural relativism does not support democracy and tolerance any more than it supports any other political system: 
If relativism signifies contempt for fixed categories and men who claim to be the bearers of an objective, immortal truth ... then there is nothing more relativistic than Fascist attitudes and activity. ... From the fact that all ideologies are of equal value, that all ideologies are mere fictions, the modern relativist infers that everybody has the right to create for himself his own ideology and to attempt to enforce it with all the energy of which he is capable. ${ }^{18}$

Indeed, it should not surprise us that those who begin with relativism should end with a fierce and intolerant assertion of their ideologies, because relativism is psychologically impossible to sustain. Everyone makes judgments about good and bad, right and wrong, all the time. People may say that these are just "value judgments," that they are entirely subjective and hold no universal validity, but no one can consistently live or even talk as if this were true. The principles that people believe in, that they want to pass on to their children and students, hold an entirely different meaning for them than what they recognize as their private, idiosyncratic preferences. Everyone holds his deepest principles to be universally valid, whether he believes above all in the virtue of faith or the virtue of humane tolerance or the virtue of authentic commitment.

The fact that the relativistic position is both dangerous and psychologically unsustainable does not, of course, prove that it is false, or that there is an absolute truth about right and wrong and the just ordering of society, or that such a truth is accessible to us through reason. It only means that we would do well to look for such a truth, rather than dogmatically insist that it is not to be found. Lessing once defined dogmatism as the confusion of the goal of one's thought with the point at which one becomes tired of thinking, and dogmatic relativists seem to grow tired of thinking before they even begin. ${ }^{19}$ Dogmatic relativism is as inimical to the spirit of fair-minded inquiry as is dogmatic moralism or chauvinism. Although they appear to be opposites, these positions resemble each other in striking ways. Adherents of both views are self-satisfied, and hence unwilling to listen to other points of view and grapple with them seriously. As dogmatic moralists are certain that they possess the truth and have nothing to learn from anybody, dogmatic relativists are equally certain that no one possesses the truth and that those who disagree with them are no wiser than they are, but only different. The dogmatic moralists refuse to examine themselves because they are certain they are good, the relativists because they feel no need to justify their views since they can defend the views simply by saying, "These are my values." Both have an incomplete self-understanding. Traditional dogmatists tend to deceive themselves by deny- 
ing whatever doubts they have; dogmatic relativists do the same thing by denying their critical judgments. Both positions, in short, are shallow.

Students who are taught relativism year after year, although deeply affected by it, are never wholly convinced. As a result, they become an incoherent mixture of these two extremes, with unfortunate consequences for education. Having heard time and again that no society is any better than any other, they have little motive for wanting to know about other societies; indifference is a much more common result of relativism than is true respect for other ways of life. But while relativism can sap their interest in history, geography, and literature, it does not dissolve the judgments that lurk deep within. These judgments tend to remain unacknowledged, however, and hence they cannot be educated and refined through reasoned discourse. The education that students need, and that multicultural studies can provide, is one that will bring them to a deeper thoughtfulness by helping them to integrate and develop their questions, their conscience, their common sense, and their capacity for reasoned judgment. They need to balance commitment and judgment with open-mindedness, and that requires a willingness to engage in serious discourse about what is good and bad, admirable and not admirable. How can teachers push beneath students' superficial relativism to create such genuine openness?

It is easy enough to show students that they do indeed believe in right and wrong and good and bad social institutions. One need only take extreme examples such as Nazis shooting babies, or slavery, or apartheid. The reason students keep slipping back into a relativistic position, despite their knowledge of these clear cases, is that they believe that they can be good and kind people only if they are tolerant and that they can be tolerant only if they are relativists. What they need is to see toleration in perspective, as one part but by no means the whole of the virtue of humanity. There are things that should be tolerated and things that it is inhumane to tolerate, and only with clarity about basic principles can one tell the difference. Students need to be shown, by the same token, that judgment is not inherently bad. The derogatory word "judgmental" that we now hear so often is one of those careless terms that blurs important distinctions. It conflates valid judgments with those that are hasty and groundless and judgments that are voiced with a constructive purpose with those that are spoken only in order to hurt. Judgments can indeed lead to hurt feelings, although hurt feelings are often the necessary prelude to growth or reformation. Such judgments should be voiced with great caution, then, but not banished altogether. 
Students also need to be reminded that the mere fact of disagreement does not mean that there is no truth. It only means that some or all people are ignorant of it, and probably that the truth is difficult to find. Nor is it necessary to persuade everyone of one's view in order to in fact be right. There may always be diehard partisans of apartheid, yet one may rightly conclude from the evidence that the policy of apartheid is neither just nor well suited to promoting the happiness of nations. What is more important than convincing all opponents is being able to satisfy oneself that one has considered their arguments and has sufficient answers for them.

Inevitably, students will ask, "Who's to say which moral beliefs are right, or which culture's system of laws is best?" Teachers can reply that it is the responsibility of everyone to try to judge these things, in open and fairminded discussion with one another. Students who are studying another society should make every effort to give the benefit of the doubt, and should also give greater weight to the testimony of those who know it firsthand than to their own judgments. There are societies that need barbed wire to keep people out and others that need it to keep people in, and it would be arrogant in the extreme to say that those who seek to escape oppression are wrong because all societies are equally good. The fact that people can assert the equality of all societies or cultures, despite their recognition of the evils of tyranny, suggests a naive ignorance of the power of the political regime to shape all aspects of culture. Reading the works of communist dissidents such as Vaclav Havel and Alexander Solzhenitsyn, who have written eloquently about the social and moral ills caused by communism, can help correct this misunderstanding, at the same time that it gives students an inside perspective on totalitarian society and an outside perspective on our own.

Reaching a thoughtful middle ground between relativism and dogmatism means knowing what one's principles are and what the arguments are for these principles, but also recognizing that at the root of cultural differences lie difficult questions, with cases to be made on both sides. Students should see, for instance, that there are good arguments for a close-knit, communitarian, tribal kind of life, as well as for extensive individual liberty. Even while they believe that democracy is the best form of government, they should recognize that it may not have all the advantages on its side, and that very thoughtful men and women have favored other forms of government. They should see that there is a case to be made for such systems as theocracy and aristocracy, and that we have things to learn by engaging in these arguments. Exploring alternatives and looking for answers to the challenges 
they present can lead students to a deeper grasp of their own country's principles. It can make them better democrats, not in the sense of being more partisan democrats, but in the sense of being more thoughtful and moderate, and hence better able to compensate for democracy's characteristic weaknesses or blind spots. For this purpose, reading a sympathetic critique of democracy from an aristocratic perspective, such as Tocqueville's Democracy in America, is extremely helpful. At the same time, a recognition of the depth of the issues that divide truly different cultures will help students to see that the United States, for all its vaunted cultural diversity, enjoys virtual unanimity regarding the most important aspects of culture: the political system and the relation of religious authorities to political ones.

\section{Program Organization and Teaching Strategies}

How would a serious multicultural education be structured, then, so as to foster the kind of thoughtful judgment that is needed? The program would balance the study of America with a study of the Western tradition of which it is a part and with explorations of wholly different traditions. It would include some knowledge of many societies throughout the world and throughout history, and a deeper knowledge of a few. By studying a variety of other societies, students can get a sense of what the range of human possibilities is and of what is constant in human nature. Ohio's guidelines for multicultural education express the usual aim of teaching students to value diversity in American society and, in Justice William O. Douglas's words, to appreciate "the flowering of man and his idiosyncrasies." ${ }^{20}$ A more basic and valuable lesson to be gleaned from multicultural studies, however, is the knowledge of what is universal and what is only the growth of our own particular time and place. A recognition of the virtues that are respected everywhere can help correct the thoughtless assumption that morals are completely variable or relative. A study of many different political systems and political experiments gives citizens the foundation for prudence and good judgment in political affairs: an understanding of the natural limits of politics, or of what can reasonably be hoped for from political action and what is a utopian and dangerous dream.

A good program would be structured so as to give students extensive information with which to make judgments about social and political issues. Substantive knowledge of a number of different societies allows one to recall historical precedents and parallels for current developments and to assess 
them intelligently for oneself. There is no substitute for knowing a great deal of history, understanding it in context, and being able to make informed judgments about how events are likely to unfold. This is where some of the newer approaches to multicultural studies threaten to leave students seriously deprived. The New York Social Studies Review and Development Committee, wisely recognizing the impossibility of covering all parts of the world and all periods of history comprehensively and in meaningful depth (and at the same time wanting desperately to be evenhanded), advises schools to shift their emphasis away from information and toward the tools, concepts, and intellectual processes that allow one to be an "autonomous learner." Hence they recommend that schools abandon the traditional organization of history and geography courses in favor of courses organized around key concepts. Teachers would then draw relevant examples from a variety of cultures to illustrate each concept. ${ }^{21}$ Taking events out of context in this way, however, will leave students dependent on their teachers' interpretations of the events, their causes, and the unfamiliar cultures in which they have taken place. Events viewed in isolation as examples of some general point are harder to retain in one's memory than events that make sense as part of a continuous narrative. Students educated in this way will come away without solid knowledge of any other society and without practice in marshaling their own knowledge to form independent assessments of events. In education circles it has become quite fashionable to de-emphasize facts at the expense of concepts or skills, on the questionable assumption that information is easy to obtain whenever one needs it - and on the strange assumption that one must choose between information and concepts or thinking skills. This approach neglects the consideration that students who are never required to move systematically and carefully from facts to general ideas may never feel the need for the knowledge that they lack. Rather than reaching independent conclusions, they will simply adopt the popular ideas of their times. There is much talk these days about critical thinking and much too little attention paid to the habits of patience and thoroughness and respect for knowledge that are its necessary foundation.

In addition to providing students with broad knowledge of the world and a habit of using it well, a good multicultural studies program would also focus in depth on a few societies that stand as challenging alternatives to our own. In the later grades especially, breadth of coverage would be foregone for the sake of depth, and teachers would have freedom to focus on the specific countries and periods that they know well and find most fruitful to 
teach. An intimate knowledge of one society that differs deeply from ours can provoke more thoughtfulness and more of a disposition to regard others with respectful openness than giving students a whirlwind tour of many cultures. One need not even go far afield to give students such a perspective. Ancient Greece, though the source of much that we cherish and much that we take for granted, can also provide some of the deepest challenges to us, with its paganism, its public supervision of religion and the arts, its variety of political regimes, brilliantly justified, and its dedication to smallness and military valor.

Allowing teachers to focus on the countries and periods of history that they themselves find most admirable can also help promote respect for other cultures as a whole. This is one of the great limitations of multicultural studies that look only at immigrant groups within North America. It is not reasonable to expect that a society's finest achievements will be particularly visible among immigrants to another country, since the immigrants' energies will be consumed in establishing a new life for themselves and fitting into a new society. American history courses should of course include the study of minorities as an integral part of our history, and the study of immigrant groups can be an excellent prelude to the study of the countries that they came from, especially for younger students. But if the goal is to provoke thought and respect for another group, the best multicultural literature for students to read will not be stories of immigrants' sufferings or of others who have been hurt by their contact with the West, but classics from within those cultures themselves.

Respect for other cultures also comes through learning about impressive individuals within those societies. Young people have a great need for models that they can admire and pattern their lives after, as George Washington did with Cato and as our students continue to do with rock stars and whoever else seizes their imagination. For all their talk about the importance of role models, many educators do not understand students' need for inspiration; and they single out figures for special attention not on the basis of their virtues or the captivating drama of their lives, but on the basis of skin color, gender, and physical disability. The Organization of American Historians recommends that "the history curriculum of public schools should be constructed around the principle that all people have been significant actors in human events." ${ }^{22}$ The most thoroughly egalitarian form of history instruction would no doubt be to study lives chosen at random, but this would do nothing to nourish the mind or the heart. Stories and especially biographies 
of remarkable people are valuable in the same way that the best novels are: they give us models that we can keep in our minds as reference points all our lives and that we can use to help sort out our own aspirations. If we look impartially for inspiring models in all continents, they will naturally come in all colors. One who admires Anwar Sadat will care little about the color of his skin; and the more eclectic one's stock of heroes is, the harder it will be to be prejudiced.

Once students have a preliminary acquaintance with a society that they are studying, the teachers need to listen carefully to their judgments. If instructors do not elicit and address students' honest responses to the material, the students will remain detached, and the course will seem dry and "academic." Only by engaging students fully can teachers educate their judgments. Honest judgments can of course be explosive, especially if the subject is American ethnic groups. This is one advantage to studying the history and literature of other periods: if the class is investigating ancient Rome or Egypt, no one in the room need feel offended by criticisms leveled against that society. Once students have learned habits of judging carefully and giving the benefit of the doubt in their study of other cultures, they will be able to apply these same habits to their analysis of events near at hand.

The next step after clarifying one's initial judgments, however, is to suspend these judgments and try to understand the case for the other side. Despite their initial prejudices, students are often surprisingly willing to consider the arguments for other regimes and ways of life if they are given the task of defending these in essays or debates. Teachers can help them make serious arguments by pointing them to relevant texts and documents from the society under study. If they are assigned to explain the position of the elders of the Massachusetts Bay Colony who banished Anne Hutchinson, for instance, they would be encouraged to resist the initial temptation to judge them in terms of modern conceptions of religious liberty and first to give a sympathetic reading to the early Puritan speeches that show their very different conception of society's purpose and the spiritual duties of magistrates.

Meaningful courses can be structured so as to allow generous scope for the issues that provoke a strong reaction in students and hence engage their interest most fully. These initial reactions or judgments can be used to formulate guiding questions for research. In a unit on India, for example, students are likely to respond more intensely to the caste system or to arranged marriages than to issues of industrialization and sanitation. They might ask how the caste system got started, why it persisted so long, and why it is still 
powerful even now that it is illegal. Students would confront the injustice of the early Aryans, who set themselves up as the highest caste; but they would also learn about the Hindu teachings of reincarnation and the soul's gradual progress to Nirvana, in stages corresponding to the castes. They would consider the strong sense of community and belonging and order that such a system gives to life, and perhaps contrast an Indian community with utopian American attempts to forge close-knit communities.

Rather than criticize the caste system from the perspective of our principles, they would notice that there have been Indian critics of it from the outset and that their perspective is different from ours. Many of the protest movements that sprang up in the Middle Ages, such as the Virasaiva movement of the tenth to twelfth centuries, were egalitarian in a sense, not because they believed in democracy as such, but because they were trying to create a community of saints. They believed that enlightenment could come in one lifetime to members of any caste. If students compare their own tendency to value individual freedom for the sake of getting ahead in life with the Indian focus on spiritual things, their respect for India will grow. This comparison could lead them to a reexamination of their own understanding of human rights. Perhaps what is really best and most important about individual liberty is not its contribution to economic self-advancement, but the fact that it allows for freedom of thought and of conscience-a freedom to live a spiritual life, but also to follow the religion or philosophy that one finds most persuasive. A study of this nature would help students to see that the caste system is neither simply cynical nor simply destructive. Examining its power to persist and the nature of the protests against it can help Americans to see their lives in better perspective. In the end, such a process will give students wiser and more moderate judgments, judgments that reflect more understanding, a sense of the complexity of the issues, and a greater willingness to consider other views in the future.

This sketch of a multicultural civic education is undeniably ambitious. By the end of high school, students cannot be expected to attain a complete understanding of American principles or a full appreciation of what even one other culture has to offer. It is extraordinarily hard to get outside of one's own terms of reference and the prejudices of one's own culture to understand another on its own terms. Teachers who are to help students to make a successful start at this ought to have a thorough grounding in history themselves, which unfortunately most jurisdictions do not require social studies teachers to have. They need some understanding of world religions 
and of the arguments for and against different regimes, different family structures, and different ways of balancing the claims of the individual against the claims of society. They need, in the best case, some acquaintance with political philosophy. Yet any teacher who is thorough, openminded, and willing to learn can make progress together with her students; and in twelve years of serious and unhurried history and geography courses, students can make an excellent beginning. Even if the best civic education is rarely attained, having a clear vision of the goal is invaluable. A frank investigation of other societies that welcomes judgments about good and bad can be safely engaged in without fear of promoting more bigotry, because the issues that divide societies are hard issues. If questions about how human beings should live together and govern themselves were easy, everyone would adopt the same laws and customs, just as we all sleep lying down at night, and not sitting or standing in stalls. Because the questions are hard, there is almost always something to be said on both sides and almost always something to be learned from the other side. And the experience of learning from each other is in the end the best way to generate mutual respect and goodwill. At the same time, if teachers help students to understand the strongest case for liberal democracy, and if they investigate other countries not with a view to denigrating ours, but with a view to finding constructive lessons for it, such openness will promote not only tolerance but civic health more broadly. We close, then, with a paradox. Just as racism may best be overcome through a broad civic education that looks beyond race to deeper issues, so the best civic education for America may be a liberal education, which looks beyond the civic concerns of our society to contemplate humanity itself.

\section{Notes}

1. James Banks, Multiethnic Education: Theory and Practice (Boston: Allyn and Bacon, 1981), ch. 5; New York State Social Studies Review and Development Committee, One Nation, Many Peoples: A Declaration of Cultural Interdependence (June 1991), xii.

2. Noah Webster, A Grammatical Institute, of the English Language, Comprising, an Easy, Concise, and Systematic Method of Education, Designed for the Use of English Schools in America. In Three Parts, pt. 1 (Hartford, Conn.: Hudson and Goodwin, 1783; facsimile reprint, Menston, England: Scolar Press, 1968), 14.

3. Ontario Ministry of Education, The Common Curriculum (1993), 25-29; also New York State Social Studies Review and Development committee. In this context, see especially the dissenting opinions of Arthur M. Schlesinger, Jr., and Kenneth Jackson.

4. Pennsylvania Bulletin 23, no. 30 (July 24, 1993): 3553; State of Iowa Department of 
Public Instruction, A Guide to Developing Multicultural, Nonsexist Education Across the Curriculum (May 1989), 14-17.

5. New York State Social Studies Review and Development committee, 1.

6. See Diane Ravitch, "Multiculturalism: E Pluribus Plures," American Scholar 59, no. 3 (Summer 1990): 337-54.

7. Molefi Kete Asante, "The Afrocentric Idea in Education," Journal of Negro History 60, no. 2 (Spring 1991): 170-80; Leonard Jeffries, quoted by Joseph Berger, "Professors' Theories on Race Stir Turmoil at City College," New York Times, 20 April 1990; Arthur M. Schlesinger, Jr., The Disuniting of America (n.p.: Whittle Direct Books, 1991), 35-43.

8. New York State Department of Education, A Curriculum of Inclusion: Report of the Commissioner's Task Force on Minorities: Equity and Excellence (July 1989), 35; State of Iowa Department of Public Instruction, Multicultural Nonsexist Education: Social Studies (1979, reprinted 1991), 3, 8: like A Curriculum of Inclusion, this document speaks of the need to root out "patronizing attitudes" toward females and minorities. See also Leroy G. Baruth and M. Lee Manning, Multicultural Education of Children and Adolescents (Boston: Allyn and Bacon, 1992), 148-52.

9. Brent Bridgeman and Virginia Shipman, "Preschool Measures of Self-Esteem and Achievement Motivation as Predictors of Third Grade Achievement," Journal of Educational Psychology 70, no. 1 (February 1978): 17-28; Edward Kifer, "Relation Between Academic Achievement and Personality Characteristics: A Quasi-Longitudinal Study," American Educational Resources Journal 12, no. 2 (Spring 1975): 191-210; Rosalyn A. Rubin, Jeanne Dorle, and Suzanne Sandridge, "Self-Esteem and School Performance," Psychology in the Schools 14, no. 4 (October 1977): 503-7; see also Barbara Byrne, "The General/ Academic Self-Concept Nomological Network: a Review of Construct Validation Research," Review of Education Research 54, no. 3 (Fall 1984): 427-56.

10. Craig Frisby and Carolyn Tucker, "Black Children's Perception of Self: Implications for Educators," Educational Forum 57, no. 2 (Winter 1993): 146-54.

11. Ronald Edmonds, "Effective Schools for the Urban Poor," Educational Leadership 37, no. 1 (October 1979): 15-24; Thomas Sowell, "Pattern of Black Excellence," ch. 2 in Education: Assumptions vs. History (Stanford, Calif.: Hoover Institution Press, 1986).

12. See especially Dinesh D'Sousa, Illiberal Education: The Politics of Race and Sex on Campus (New York: Vintage Books, 1992), ch. 5.

13. Thomas Jefferson, Notes on the State of Virginia, ed. William Peden (New York: W. W. Norton, 1954), Query XVII, 160-61.

14. Agnes Cameron, quoted in Andrew Nikiforuk, School's Out (Toronto: Macfarlane Walter \& Ross, 1993), 26.

15. Banks, 26.

16. Thomas Jefferson, "A Bill for Amending the Constitution of the College of William and Mary, and Substituting More Certain Revenues for Its Support," in The Papers of Thomas Jefferson, ed. Julian P. Boyd et al. (Princeton, N.J.: Princeton University Press, 1950- ), 539-40; Notes on the State of Virginia, Query XV, 150-51. 
17. This position is often incoherent. There is great pressure to study literature and scholarship written by women and homosexuals and minorities, on the grounds that only in this way can one get a true diversity of views. It is thought, for example, that whites cannot study or write knowledgeably about blacks. But if we truly cannot understand one another's perspectives, why should a student study with or read the works of anyone of another race or gender?

18. Benito Mussolini, cited in Jerry Martin, "The Postmodern Argument Reconsidered," Partisan Review 60, no. 4 (Fall 1993): 653.

19. Gotthold Lessing, Letter to Mendelssohn, 9 January 1771, quoted in Leo Strauss, Natural Right and History (Chicago: University of Chicago Press, 1953), 22. The first two chapters of this book give an extremely helpful account of the philosophic roots of relativism.

20. Ohio Department of Education, Citizenship, Multiculturalism, and Human Relations Education (1985), 5.

21. New York State Social Studies Review and Development Committee, 16-17, 20-21.

22. New York State Social Studies Review and Development Committee, 20. 


\section{Part IV}

Multiculturalism and the Arts 
This page intentionally left blank 


\title{
Chapter 13 \\ What Is a Classic?
}

\author{
J. M. Coetzee
}

In October of 1944, as Allied forces were battling on the European mainland and German rockets were falling on London, Thomas Stearns Eliot, aged 56, gave his presidential address to the Virgil Society in London. In his lecture Eliot does not mention wartime circumstances, save for a single reference-oblique, understated, in his best British manner-to "accidents of the present time" that have made it difficult to get access to the books he needs to prepare the lecture. It is a way of reminding his auditors that there is a perspective in which the war is only a hiccup, however massive, in the life of Europe.

The title of the lecture was "What Is a Classic?" and its aim was to consolidate and reargue a case Eliot had long been advancing: that the civilization of Western Europe is a single civilization, that its descent is from Rome via the Church of Rome and the Holy Roman Empire, and that its originary classic must therefore be the epic of Rome, Virgil's Aeneid. ${ }^{\prime}$ Each time this case was reargued, it was reargued by a man of greater public authority, a man who by 1944 , as poet, dramatist, critic, publisher, and cultural commentator, could be said to dominate English letters. This man had targeted London as the metropolis of the English-speaking world, and with a diffidence concealing ruthless singleness of purpose had made himself into the deliberately magisterial voice of that metropolis. Now he was arguing for Virgil as the dominant voice of metropolitan, imperial Rome, and Rome, furthermore, imperial in transcendent ways that Virgil could not have been expected to understand.

"What Is a Classic?" is not one of Eliot's best pieces of criticism. The address de haut en bas, which in the 1920s he had used to such great effect to impose his personal predilections on the London world of letters, has become mannered. There is a tiredness to the prose, too. Nevertheless, the piece is never less than intelligent, and-once one begins to explore its background-more coherent than at first reading one might think. Furthermore, behind it is a clear awareness that the ending of World War II must bring 
with it a new cultural order, with new opportunities and new threats. What struck me when I reread Eliot's lecture, however, was the fact that nowhere does Eliot reflect on the fact of his own Americanness, or at least his American origins, and therefore on the somewhat odd angle at which he comes, honoring a European poet to a European audience.

I say "European," but of course even the Europeanness of Eliot's British audience is an issue, as is the line of descent of English literature from the literature of Rome. For one of the writers Eliot claims not to have been able to reread in preparation for his lecture is Sainte-Beuve, who in his lectures on Virgil claimed Virgil as "the poet of all Latinity," of France and Spain and Italy but not of all Europe. ${ }^{2}$ So Eliot's project of claiming a line of descent from Virgil has to start with claiming a fully European identity for Virgil and also with asserting for England a European identity it has not always been eager to embrace. ${ }^{3}$

Rather than trace in detail the moves Eliot makes to link Virgil's Rome to the England of the 1940s, let me ask how and why Eliot himself became English enough for the issue to matter to him. ${ }^{4}$

Why did Eliot "become" English? My sense is that at first the motives were complex: partly from Anglophilia, partly in solidarity with the English middle-class intelligentsia, partly as a protective disguise in which a certain shame about American barbarousness may have figured, partly as a parody from a man who enjoyed acting (passing as English is surely one of the most difficult acts to bring off). I would suspect that the inner logic was, first, residence in London (rather than England), then the assumption of a London social identity, then the specific chain of reflections on cultural identity that would eventually lead him to claim a European and Roman identity in which London identity, English identity, and Anglo-American identity were subsumed and transcended. ${ }^{5}$

By 1944 the investment in this identity was total. Eliot was an Englishman-though, in his own mind at least, a Roman Englishman. He had just completed a cycle of poems in which he named his roots and reclaimed as his own East Coker in Somersetshire, home of the Elyots. "Home is where one starts from," he writes. "In my beginning is my end." "What you own is what you do not own"-or, to put it another way, what you do not own is what you own. ${ }^{6}$ Not only would he now claim for himself that sense of roots that is so important to his understanding of culture, but he had equipped himself with a theory of history that defined England and America as provinces of an eternal metropolis, Rome. 
So one can understand how it is that in 1944 Eliot feels no need to present himself to the Virgil Society as an American talking to Englishmen. But how does he present himself?

For a poet who had such success, in his heyday, in importing the yardstick of impersonality into criticism, Eliot's poetry is astonishingly personal, not to say autobiographical.' So it is not surprising to discover, as we read the Virgil lecture, that it has a subtext concerning Eliot himself. But the figure of Eliot in the lecture is not in the first place Virgil, but Aeneas, the hero of Virgil's epic poem-Aeneas understood or even transformed in a particularly Eliotic way into a rather weary middle-aged man who "would have preferred to stop in Troy, but becomes an exile,... exiled for a purpose greater than he can know, but which he recognises." "Not, in a human sense, a happy or successful man," whose "reward [is] hardly more than a narrow beachhead and a political marriage in a weary middle age: his youth interred."

From the major romantic episode of Aeneas's life, the affair with Queen Dido that ends with Dido's suicide, Eliot singles out for mention neither the high passion of the lovers nor Dido's Liebestod, but what he calls the "civilised manners" of the couple when they meet later in the underworld, and the fact that "Aeneas does not forgive himself ... in spite of the fact that all that he has done has been in compliance with destiny." It is hard not to see here a covert reference to Eliot's own unhappy first marriage. ${ }^{10}$

The element of what I would call compulsiveness-just the opposite of impersonality - that makes Eliot articulate the story of Aeneas, in this lecture and before this audience, as an allegory of his own life is not my concern here. What I want to point to is that in reading the Aeneid in this way, Eliot is not only using its fable of exile followed by home founding - "In my end is my beginning"- as the pattern of his own intercontinental migration-which I do not call an odyssey precisely because Eliot is concerned to validate the destiny-inspired trajectory of Aeneas over the idle and ultimately circular wanderings of Odysseus-but is also appropriating the cultural weight of the epic to back himself.

Thus in the palimpsest Eliot sets before us, he, Eliot, is not only Virgil's dutiful (pius) Aeneas, who leaves the continent of his birth to set up a beachhead in Europe (beachhead is a word one could not have used in October of 1944 without evoking the landings in Normandy just a few months earlier, as well as the 1943 landings in Italy), but Aeneas's Virgil. If Aeneas is recharacterized as an Eliotic hero, Virgil is characterized as a rather Eliot-like "learned author," whose task, as seen by Eliot, was that of "re-writing Latin 
poetry" (the phrase Eliot preferred for himself was "purifying the dialect of the tribe"). ${ }^{11}$

Of course I would be traducing Eliot if I created the impression that in 1944 he was in any simple-minded way setting himself up as the reincarnation of Virgil. His theory of history and his conception of the classic are much too sophisticated for that. To Eliot, there can be only one Virgil because there is only one Christ, one Church, one Rome, one western Christian civilization, and one originary classic of that Roman-Christian civilization. Nevertheless, while he does not go so far as to identify himself with the so-called adventist position that Virgil prophesies a new Christian era, he does leave the door open to the suggestion that Virgil was being used by an agency greater than himself for a purpose of which he could not have been aware - that is, that in the greater pattern of European history he may have fulfilled a prophetic role. ${ }^{12}$

Read from the inside, Eliot's lecture is an attempt to reaffirm the Aeneid as a classic not just in Horatian terms-as a book that has lasted a long time ${ }^{13}$ - but in allegorical terms: as a book that will bear the weight of having read into it a meaning for Eliot's own age. The meaning for Eliot's age includes not only the allegory of Aeneas the sad, long-suffering middle-aged widower hero, but the Virgil who appears in the Four Quartets as one element of the composite "dead master" who speaks to fire-warden Eliot in the ruins of London, the poet without whom, even more than Dante, Eliot would not have become himself. Read from the outside, and read unsympathetically, it is an attempt to give a certain historical backing to a radically conservative political program for Europe, a program opened up by the imminent end of hostilities and the prospect of reconstruction. Broadly stated, this would be a program for a Europe of nation-states in which every effort would be made to keep people on the land, in which national cultures would be encouraged and an overall Christian character maintained-a Europe, in fact, in which the Catholic Church would be the principal supranational organization.

Continuing this reading from the outside, at a personal but still unsympathetic level, the Virgil lecture can be fitted into a decades-long program on Eliot's part to redefine and resituate nationality in such a way that he, Eliot, cannot be sidelined as an eager American cultural arriviste lecturing the English and/or the Europeans about their heritage and trying to persuade them to live up to it-a stereotype into which Eliot's one-time collaborator Ezra Pound all too easily fell. At a more general level, the lecture is an attempt to claim a cultural-historical unity for Western European 
Christendom, including its provinces-which Eliot considered to be the home of the world's major culture ${ }^{14}$ - within which the cultures of its constituent nations would belong only as parts of a greater whole.

This is not quite the program that would be followed by the new North Atlantic order that was to emerge after the war-the urgency for its own program came from events Eliot could not have foreseen in 1944 - but it is highly compatible with that program. If Eliot got it wrong, it was by not foreseeing that the new order would be directed from Washington, not London and certainly not Rome. Looking further into the future, Eliot would of course have been disappointed by the form toward which western Europe in fact evolved-toward economic community but even more toward cultural homogeneity. ${ }^{15}$

The process I have been describing, extrapolating from Eliot's 1944 lecture, is one of the more spectacular examples of a writer attempting to make a new identity, claiming that identity not on the basis of immigration, settlement, residence, domestication, acculturation, as other people do, or not only by such means - since Eliot with characteristic tenacity did all of the above-but by defining nationality to suit himself and then using all of his accumulated cultural power to impose that definition on educated opinion, and by resituating nationality within a specific — in this case Catholicbrand of internationalism or cosmopolitanism, in terms of which he would emerge not as a Johnny-come-lately but as a pioneer and indeed a kind of prophet; a claiming of identity, furthermore, in which a new and hitherto unsuspected paternity is asserted-a line of descent less from the Eliots of New England and/or Somerset than from Virgil and Dante, or at least a line in which the Eliots are an eccentric offshoot of the great Virgil-Dante line.

"Born in a half-savage country, out of date," Pound called his Hugh Selwyn Mauberley. The feeling of being out of date, of having been born into too late an epoch, or of surviving unnaturally beyond one's term, is all over Eliot's early poetry, from "Prufrock" to "Gerontion." The attempt to understand this feeling or this fate, and indeed to give it meaning, is part of the enterprise of his poetry and criticism. This is a not uncommon sense of the self among colonials - whom Eliot subsumes under what he calls provincials-particularly young colonials struggling to match their inherited culture to their daily experience. The high culture of the metropolis provides them with extraordinarily powerful experiences, which cannot, however, be embedded in their lives in any obvious way and which seem therefore to have their existence in some transcendent realm. 
In extreme cases, such provincials blame their environment for not living up to art and take up residence, even live out their lives, in an art-realm. This is a provincial fate-Gustave Flaubert diagnosed it in Emma Bovary, subtitling his case study Moeurs de province — but particularly a colonial fate, for those colonials brought up in the culture of what is usually called the mother country but in this context deserves to be called the father country.

Eliot as a man and particularly as a young man was open to experience, both aesthetic and real-life, to the point of being suggestible and even vulnerable. His poetry is in many ways a meditation on, and a struggling with, such experiences; in the process of making them over into poetry, he makes himself over into a new person. The experiences are perhaps not of the order of religious experience, but they are of the same genre.

There are many ways of understanding a life's enterprise like Eliot's, among which I will isolate two. One, broadly sympathetic, is to treat these transcendental experiences as the subject's point of origin and read the entirety of the rest of the enterprise in their light. This is an approach that would take seriously the call from Virgil that seems to come to Eliot from across the centuries. It would trace the self-fashioning that takes place in the wake of that call as part of a lived poetic vocation. That is, it would read Eliot very much in his own framework, the framework he elected for himself when he defined tradition as an order you cannot escape, in which you may try to locate yourself, but in which your place gets to be defined, and continually redefined, by succeeding generations - an entirely transpersonal order, in fact.

The other (and broadly unsympathetic) way of understanding Eliot is the sociocultural one I outlined a moment ago: of treating his efforts as the essentially magical enterprise of a man trying to redefine the world around himself-redefining America, redefining Europe - rather than confronting the reality of his not-so-grand position, namely, that of a man whose highly academic and Eurocentric education had prepared him rather narrowly for life as a mandarin in one of the New England ivory towers.

I would like to interrogate these alternative readings-the transcendentalpoetic and the sociocultural-further, and bring them closer to our own times, following an autobiographical path that may be methodologically risky but has the virtue of dramatizing the issue.

One Sunday afternoon in the summer of 1955, when I was fifteen years old, I was mooning around our back garden in the suburbs of Cape Town, 
wondering what to do, boredom being the main problem of existence for me in those days, when from the house next door I heard music. As long as the music lasted, I was frozen, I dared not breathe. I was being spoken to by the music as music had never spoken to me before.

What I was listening to was a recording of Bach's Well-Tempered Clavier, played on the harpsichord. I learned this name only some time later, when I had become more familiar with what, at the age of fifteen, I knew onlyin a somewhat suspicious and even hostile teenage manner-as "classical music." The house next door had a transient student population; the student who was playing the Bach record must have moved out soon afterward, or lost his/her taste for Bach, for I heard no more, though I listened intently.

I don't come from a musical family. There was no musical instruction offered at the schools I went to, nor would I have taken it if it had been offered: in the colonies classical music was sissy. I could identify Khachaturian's "Sabre Dance," the overture to Rossini's William Tell, Rimsky-Korsakov's "Flight of the Bumble-Bee" - that was the level of my knowledge. At home we had no musical instrument, no record player. There was plenty of the blander American popular music on the radio (heavy emphasis on George Melachrino and his Silver Strings), but it made no great impact on me.

What I am describing is middle-class musical culture of the Age of Eisenhower, as it was to be found in the ex-British colonies, colonies that were rapidly becoming cultural provinces of the United States. The so-called classical component of that musical culture may have been European in origin, but it was Europe mediated and in a sense orchestrated by the Boston Pops.

And then the afternoon in the garden, and the music of Bach, after which everything changed. A moment of revelation that I will not call Eliotic - that would insult the moments of revelation celebrated in Eliot's poetry-but that was of the greatest significance in my life nevertheless: for the first time I was undergoing the impact of the classic.

What did Bach give me? He gave me, so to speak, the idea of form. In Bach nothing is obscure, no single step that he takes is beyond imitation. Yet when the chain of sounds is realized in time, the building process ceases at a certain moment to be the mere linking of units; the units cohere as a higher-order object in a way that I can only describe by analogy as incarnation. Bach's music is not just the incarnation of certain musical ideas, but the incarnation of higher-order ideas of exposition, complication, and resolution that are more general than music. Bach thinks in music. Music thinks itself in Bach. ${ }^{16}$ 
The revelation in the garden was a key event in my formation. Now I wish to interrogate that moment again, using as a framework both what I have been saying about Eliot-specifically, using Eliot the provincial as a pattern and figure of myself - and, in a more skeptical way, invoking the kinds of questions that contemporary cultural analysis asks about culture and cultural ideals.

The question I put to myself, somewhat crudely, is this: Is there some nonvacuous sense in which I can say that the spirit of Bach was speaking to me across the ages, across the seas, putting before me an ideal of form; or was what was really going on at that moment that I was symbolically electing high European culture, and command of the codes of that culture, as a route that would take me out of my class position in white South African society and ultimately out of what I must have felt, in whatever obscure and mystified terms, as the dead end of that society itself-a road that would culminate (again symbolically) with me writing an essay for a cosmopolitan audience on Bach, T. S. Eliot, and the question of the classic? In other words, was the experience what I understood it to be-a disinterested and in a sense impersonal aesthetic experience-or was it really the masked expression of a material interest?

This is a question of a kind that one would be deluded to think one could answer about oneself. Any autobiographical answer must be open to endless suspicion. But that does not mean it should not be asked; and asking it means asking it properly, in terms that are as clear and as full as possible. As part of the enterprise of asking the question clearly, let me therefore ask what I might mean when I talk of being spoken to by the classic across the ages. ${ }^{17}$

In two out of the three senses, Bach is a classic of music. Sense one: the classic is that which is not time-bound, which retains meaning for succeeding ages, which "lives." Sense two: a proportion of Bach's music belongs to what are loosely called "the classics," that part of European musical canon that is still widely played, if not particularly often or before particularly large audiences. The third sense, the sense that Bach does not satisfy, is that he does not belong to the revival of so-called classical values in European art starting in the second quarter of the eighteenth century.

Bach was not only too old, too old-fashioned, for the neoclassical movement: his intellectual affiliations and his whole musical orientation were toward a world that was in the process of passing from sight. In the popular and somewhat romanticized account, Bach, obscure enough in his own day and particularly in his later years, dropped entirely out of public con- 
sciousness after his death, and was resurrected only some eighty years later, mainly through the enthusiasm of Felix Mendelssohn. For several generations, in this popular account, Bach was hardly a classic at all: not only was he not neoclassical, but he spoke to no one across those generations. His music was not published; it was rarely played. He was part of music history, he was a name in a footnote in a book, that was all. ${ }^{18}$

It is this unclassical history of misunderstanding, obscurity, and silence, which if not exactly history as truth is history as one of the overlays of the historical record, that I wish to emphasize, since it calls into doubt facile notions of the classic as the timeless, as that which unproblematically speaks across all boundaries. Bach the classic was historically constituted, as I will remind you, constituted by identifiable historical forces and within a specific historical context. Only once we have acknowledged this point are we in a position to ask the more difficult questions: What, if any, are the limits to that historical relativization of the classic? What, if anything, is left of the classic after the classic has been historicized, that may still claim to speak across the ages?

In 1737 , in the middle of the third and last phase of his professional life, Bach was the subject of an article in a leading musical journal. The article was by a one-time student of Bach's named Johann Adolf Scheibe. In it, Scheibe attacked Bach's music as "turgid and sophisticated" rather than "simple and natural," as merely "sombre" when it meant to be "lofty," and generally as marred by signs of "labour and ... effort."19

As much as it was an attack by youth upon age, Scheibe's article was a manifesto for a new kind of music based on Enlightenment values of feeling and reason, dismissive of the intellectual heritage (scholastic) and the musical heritage (polyphonic) behind Bach's music. In valuing melody above counterpoint, unity, simplicity, clarity, and decorum against architectonic complexity, and feeling above intellect, Scheibe speaks for the blossoming modern age and in effect makes Bach, and with Bach the whole polyphonic tradition, into the last gasp of the dead Middle Ages.

Scheibe's stance may be polemical, but when we remember that Haydn was only a child of five in 1737 and Mozart not yet born, we must recognize that his sense of where history was going was accurate. ${ }^{20}$ Scheibe's verdict was the verdict of the age. By his last years Bach was a man of yesterday. What reputation he had was based on what he had written before he was forty.

All in all, then, it is not so much the case that Bach's music was forgotten after his death as that it did not find a place in public awareness during 
his lifetime. So if Bach before the Bach revival was a classic, he was not only an invisible classic but a dumb classic. He was marks on paper; he had no presence in society. He was not only not canonical, he was not public.

How, then, did Bach come into his own? Not, it must be said, via the quality of the music pure and simple, or at least not via the quality of that music until it was appropriately packaged and presented. The name and the music of Bach had first to become part of a cause, the cause of German nationalism rising in reaction to Napoleon and of the concomitant Protestant revival. The figure of Bach became one of the instruments through which German nationalism and Protestantism were promoted; reciprocally, in the name of Germany and Protestantism Bach was promoted as a classic; the whole enterprise being aided by the Romantic swing against rationalism and by enthusiasm for music as the one art privileged to speak directly from soul to soul.

The first book on Bach, published in 1802, tells much of the story. It was entitled The Life, Art and Works of J. S. Bach: For patriotic admirers of genuine musical art. In his introduction the author writes: "This great man ... was a German. Be proud of him, German fatherland.... His works are an invaluable national patrimony with which no other nation has anything to be compared." ${ }^{21}$ We find the same emphasis on the Germanness and even the Nordicness of Bach in later tributes. The figure and the music of Bach became part of the construction of Germany and even of the so-called Germanic race.

The turning point from obscurity to fame came with the oft-described performances of the St. Matthew Passion in Berlin in 1829, directed by Mendelssohn. But it would be naive to say that in these performances Bach returned to history on his own terms. Mendelssohn arranged Bach's score not only in the light of the larger orchestral and choral forces at his command but also in the light of what had been going down well recently with Berlin audiences, audiences that had responded rapturously to the Romantic nationalism of Weber's Der Freischütz. It was Berlin that called for repeat performances of the Matthew Passion. In Königsberg, Kant's city and still a center of rationalism, by contrast, the Matthew Passion flopped, and the music was criticized as "out-of-date rubbish." ${ }^{22}$

I am not criticizing Mendelssohn's performances for not being "the real Bach" - that will just land us in a metaphysical forest. The point I make is a simple and limited one: the Berlin performances, and indeed the whole Bach revival, were powerfully historical in ways that were largely invisible to the moving spirits behind them. Furthermore, one thing we can be certain of about our own understanding and performance of Bach, even-and per- 
haps even particularly-when our intentions are of the purest, the most puristic, is that it is historically conditioned in ways invisible to us. And the same holds for the opinions about history and historical conditioning that I am expressing at this moment.

By saying this I do not mean to fall back into a helpless kind of relativism. The Romantic Bach was partly the product of men and women responding to unfamiliar music with a stunned overwhelmedness analogous to what I myself experienced in South Africa in 1955 and partly the product of a tide of communal feeling that found in Bach a vehicle for its own expression. Many strands of that feeling - its aesthetic emotionalism, its nationalistic fervor-are gone with the wind, and we no longer weave them into our performances of Bach. Scholarship since Mendelssohn's day has given us a different Bach, enabling us to see features of Bach invisible to the revivalist generation-for instance, the sophisticated Lutheran scholasticism within whose context he worked..$^{23}$

Such recognitions constitute a real advance in historical understanding. Historical understanding is understanding of the past as a shaping force upon the present. Insofar as that shaping force is tangibly felt upon our lives, historical understanding is part of the present. Our historical being is part of our present. It is that part of our present-namely, the part that belongs to history - that we cannot fully understand, since it requires us to understand ourselves not only as objects of historical forces but as subjects of our own historical self-understanding.

It is in the context of paradox and impossibility I have been outlining that I ask myself the question: Am I far away enough from 1955, in time and in identity, to begin to understand my first relation to the classic-which is a relation to Bach-in a historical way? And what does it mean to say that I was being spoken to by a classic in 1955 when the self that is asking the questions acknowledges that the classic - to say nothing of the self-is historically constituted? As Bach for Mendelssohn's 1829 Berlin audience was an occasion to embody and, in memory and reperformance, to express aspirations, feelings, self-validations that we can identify, diagnose, give names to, place, even foresee the consequences of, what was Bach in South Africa in 1955, and in particular what was the nomination of Bach as the classic, the occasion for? If the notion of the classic as the timeless is undermined by a fully historical account of Bach-reception, then is the moment in the garden - the kind of moment that Eliot experienced, no doubt more mystically and more intensely, and turned into some of his greatest poetry—undermined as well? 
Is being spoken to across the ages a notion that we can entertain today only in bad faith?

To answer this question, to which I aspire to give the answer no, and therefore to see what can be rescued of the idea of the classic, let me return to the story of Bach, to the half of the story that I have not yet told.

A simple question. If Bach was so obscure a composer, how did Mendelssohn know his music?

If we follow closely the fortunes of Bach's music after his death, attending not to the reputation of the composer but to actual performance, it begins to emerge that, though obscure, Bach was not quite as forgotten as the revivalist history would lead us to believe. Twenty years after his death, there was a circle of musicians in Berlin regularly performing his instrumental music in private, as a kind of esoteric recreation. The Austrian ambassador to Prussia was for years a member of this circle and on his departure took copies of Bach back to Vienna, where he held performances of Bach in his home. Mozart was part of his circle; Mozart made his own copies and studied the Art of Fugue closely. Haydn was also in the circle.

Thus a certain limited Bach tradition, which was not a Bach revival simply because continuity with Bach's own time was never broken, existed in Berlin and branched to Vienna, among professional musicians and serious amateurs, though it did not express itself in public performance.

As for the choral music, a fair amount of it was known to professionals like C. F. Zelter, director of the Berlin Singakademie. Zelter was a friend of Mendelssohn's father. It was at the Singakademie that the young Felix Mendelssohn first came across the choral music, and, against the general uncooperativeness of Zelter, who regarded the Passions as unperformable and of specialist interest only, had his own copy of the Matthew Passion made and plunged into the business of adapting it for performance.

I say of specialist (or professional) interest only. This is the point where parallels between literature and music, the literary classics and the musical classics, begin to break down, and where the institutions and practice of music emerge as perhaps healthier than the institutions and practice of literature. The musical profession has ways of keeping what it values alive that strike me as qualitatively different from the ways in which the institutions of literature keep submerged but valued writers alive.

Because becoming a musician, executant or composer, not only in the Western tradition but in other major traditions of the world, entails long 
training and personal apprenticeship to a succession of teachers; because the nature of the training entails repeated performance for the ears of others and minute listening and practical criticism, together with memorization; because a range of kinds of performance, from playing for one's teacher to playing for one's class to varieties of public performance, has become institutionalized-for all of these reasons, it is possible to keep music alive and indeed vital within professional circles while it is not part of public awareness, even among educated people.

If there is anything that gives one confidence in the classic status of Bach, it is the testing process that he has been through within the profession. Not only did this provincial religious mystic outlast the Enlightenment turn toward rationality and the metropolis, but also he survived what, for many others, would have been the kiss of death, namely, being promoted during the nineteenth-century revival as a great son of the German soil. And today, every time a beginner stumbles through the first prelude of the " 48 ," Bach is being tested again, within the profession. Dare I suggest that the classic in music is what emerges intact from this process of day-by-day testing?

The criterion of testing and survival is not just a minimal, pragmatic, Horatian standard (Horace says, in effect, that if a work is still around a hundred years after it was written, it must be a classic). It is a criterion that expresses a certain confidence in the tradition of testing and a confidence that professionals will not devote labor and attention, generation after generation, to sustaining pieces of music whose life functions have terminated.

It is this confidence that enables me to return to the autobiographical moment at the center of this essay, and to the alternative analyses I proposed of it, with a little more optimism. About my response to Bach in 1955, I asked whether it was truly a response to some inherent quality in the music and not in fact a symbolic election on my part of European high culture as a way out of a social and historical dead end. It is of the essence of this skeptical questioning that the term Bach should stand simply as a counter for European high culture, that Bach or Bach should have no value in himself or itself-that the notion of "value in itself" should in fact be the object of skeptical interrogation.

By not invoking any idealist justification of "value in itself" or trying to isolate some quality, some essence of the classic, held in common by works that survive the process of testing, I hope I have allowed the terms Bach and the classic to emerge with a value of their own, even if that value is only in the first place professional and in the second place social. Whether at the age 
of fifteen I understood what I was getting into is beside the point: Bach is some kind of touchstone because he has passed the scrutiny of hundreds of thousands of intelligences before me, by hundreds of thousands of fellow human beings.

What does it mean in living terms to say that the classic is what survives? How does such a conception of the classic manifest itself in people's lives?

For the most serious answer to this question, we cannot do better than turn to the great poet of the classic in our own day, the Pole Zbigniew Herbert. To Herbert the opposite of the classic is not the Romantic but the barbarian; furthermore, classic versus barbarian is not so much an opposition as a confrontation. Herbert writes from the historical perspective of Poland, a country with an embattled Western culture caught between intermittently barbarous neighbors. It is not the possession of some essentialist quality that, in Herbert's eyes, makes it possible for the classic to withstand the assault of barbarism. Rather, what survives the worst of barbarism, surviving because generations of people cannot afford to let go of it, and therefore hold on to it at all costs- that is the classic.

So we arrive at a certain paradox. The classic defines itself by surviving. Therefore the interrogation of the classic, no matter how hostile, is part of the history of the classic, inevitable and even to be welcomed. For as long as the classic needs to be protected from attack, it can never prove itself classic.

One might even venture further along this road, to say that the function of criticism is defined by the classic: criticism is that which is duty bound to interrogate the classic. Thus the fear that the classic will not survive the decentering acts of criticism may be turned on its head: rather than being the foe of the classic, criticism, and indeed criticism of the most skeptical kind, may be what the classic uses to define itself and ensure its survival. Criticism may in that sense be one of the instruments of the cunning of history.

\section{Notes}

1. T. S. Eliot, What Is a Classic? (London: Faber, 1945). Hereafter cited as WIC.

2. "Le poète de la latinité tout entière," quoted in Frank Kermode, The Classic (London: Faber 1975), 16. Sainte-Beuve's lectures were published as Etude sur Virgile in 1857.

3. In a Criterion article of 1926, Eliot claims that Britain is part of "a common culture of Western Europe." The question is, "Are there enough persons in Britain believing in that European culture, the Roman inheritance, believing in the place of Britain in that culture?" Two years later he assigns Britain a mediating role between Europe and the rest 
of the world: "She is the only member of the European community that has established a genuine empire- that is to say, a world-wide empire as was the Roman empire-not only European but the connection between Europe and the rest of the world." Quoted in Gareth Reeves, T. S. Eliot: A Virgilian Poet (London: Macmillan, 1989), 111, 85. Reeves is rightly puzzled by the passing over of the French and other empires.

4. Eliot left Harvard to study in Germany, then moved to Oxford when the war broke out, then married an Englishwoman, then tried to return to Harvard to defend his doctoral dissertation (but the ship on which he had a berth did not sail), then tried to get a job in the U.S. Navy but failed, then-it seems-simply gave up trying, stayed in England, and eventually became a British subject. If the dice had fallen another way, it is not impossible to see him getting his Ph.D., taking up the professorship that awaited him at Harvard, and resuming his American life.

For facts and chronology here, I depend on Roger Kojecky, T. S. Eliot's Social Criticism (London: Faber, 1971), 43-47.

5. Eliot made no major public statement on his decision to leave the United States. However, in a 1928 letter to Herbert Read he did, somewhat plaintively, articulate his sense of rootlessness within the country of his birth: "Some day I want to write an essay about the point of view of an American who wasn't an American, because he was born in the South and went to school in New England as a small boy with a nigger drawl, but who wasn't a southerner in the South because his people were northerners in a border state and looked down on all southerners and Virginians, and who so was never anything anywhere and who therefore felt himself to be more a Frenchman than an American and more an Englishman than a Frenchman and yet felt that the U.S.A. up to a hundred years ago was a family extension." Quoted in Russell Kirk, Eliot and his Age (New York: Random House, 1971), 56.

Three years later, in the Criterion, he saw the plight of the American intellectual as follows: "The American intellectual of today has almost no chance of continuous development upon his own soil and in the environment which his ancestors, however humble, helped to form. He must be an expatriate: either to languish in a provincial university, or abroad, or, the most complete expatriation of all, in New York." Quoted in William M. Chace, The Political Identities of Ezra Pound and T. S. Eliot (Stanford: Stanford University Press, 1973), 155. Eliot stresses, however, that this enforced deracination is more a feature of modern life than of specifically American circumstances.

6. T. S. Eliot, "East Coker," in Four Quartets (London: Faber, 1944), 22, 15, 20.

7. "Poetry is not a turning loose of emotion, but an escape from emotion; it is not the expression of personality, but an escape from personality." T. S. Eliot, "Tradition and the Individual Talent” (1919), in Selected Prose, ed. John Hayward (Harmondsworth: Penguin, 1953), 30.

8. WIC, 28,32 .

9. WIC, 21.

10. Reeves quotes the address of the Cumaean Sibyl to Aeneas (Aeneid VI. 93-94): "The 
cause of all this Trojan woe is again an alien bride [coniunx hospita], again a foreign marriage." The alien brides who cause "Trojan woe" are Helen of Troy, Phoenician Dido, and Latin Lavinia. Reeves writes, "Is not at least a portion of Eliot's woe his marriage to Vivien, an Englishwoman, a coniunx hospita?" Reeves, 47.

I might add that Eliot's reading of the meeting of Dido and Aeneas in the Underworld is hard to understand. After Aeneas has addressed her, Dido

fixed her eyes on the ground.

Her features were not more stirred by his speech

Than if they were made of hard flint or Marpesian marble.

Then she flung herself off [sese corripuit] and fled back to the

shadowy grove,

Still hostile [inimica].

Aeneid VI. 469-73, trans. L. R. Lind (Bloomington: Indiana University Press, 1963), 117.

11. WIC, 21. The degree of Eliot's conscious identification with Virgil and with Aeneas is further discussed in Reeves, 158-59.

12. In "Virgil and the Christian World" (1951), Eliot distinguishes Virgil's "conscious mind" from an aspect of his mind that remains discreetly unnamed but may be responding to higher direction. T. S. Eliot, On Poetry and Poets (London: Faber, 1957), 129. See also Reeves, 102.

13. Horace, Ep., II. i, 39: est vetus atque probus, centum qui perfecit annos. Quoted in Frank Kermode, The Classic (London: Faber, 1975), 117.

14. Western culture is "the highest culture that the world has ever known," wrote Eliot in 1948 (quoted in Chace, 203).

15. Notes toward a Definition of Culture, completed in 1948, is in effect a response to Karl Mannheim, who in Man and Society in an Age of Reconstruction argued that the problems of the industrial Europe of the future could be solved only by a shift to conscious social planning, and more generally by the encouragement of new modes of thought. Direction would have to be given by an elite that had transcended class constraints.

Eliot opposed social engineering, future planning, and dirigisme in general. He foresaw that the cultivation of elites would foster class mobility and thereby transform society. It was better, he said, "that the great majority of human beings should go on living in the place where they were born." The self-consciousness Mannheim envisaged should remain a faculty of some form of aristocracy or presiding class. See Chace, 197.

Eliot's response to the moves toward European unity represented by the Hague conference of 1948 (which mooted the idea of a European Parliament) and the founding of the Council of Europe in 1949 is contained in a public letter of 1951, in which, distinguishing cultural questions from political decisions, he advocates a long-term effort to convince the people of Western Europe of their common culture and to conserve and cultivate regions, races, languages, each having a "vocation" in relation to the others. See 
Kojecky, 214; see also T. S. Eliot, "The Man of Letters and the Future of Europe” (1944), reprinted in Sewanee Review (1945): 336-40, and quoted in Kojecky, 202. For fuller discussion of Eliot's debate with Mannheim, see Chace, 196-207.

16. Goethe: "It is as if the eternal harmony were conversing with itself as it may have done in the bosom of God just before the creation of the world." Quoted in Friedrich Blume, Two Centuries of Bach, trans. Stanley Godman (London: Oxford University Press, 1950), 47.

17. I do not address the hypothetical question of whether I could have been "spoken to" by Bach if I had been not only a musical illiterate but a musical illiterate brought up in a non-Western cultural tradition. The answer is very likely no: the modalities and sonorities might have been too foreign, the rhythms too unarresting. On the other hand, one should not underestimate the seductive power of the exotic, particularly in so eclectic an age as ours.

18. Certain pieces did keep their place in specialized repertories-some of the motets, for instance, remained in the repertory of the Thomaskirche in Leipzig, where Mozart heard "Singet dem Herrn" in 1789.

19. Blume, p. 12. I have amended Godman's translation slightly.

20. The historical sense of Bach's musician sons Wilhelm Friedemann, Carl Philipp Emmanuel, and Johann Christian was accurate too: not only did they do nothing after their father's death to promote his music or keep it alive, but they swiftly established themselves as leading exponents of the new music of reason and feeling.

During his later years in Leipzig Bach was regarded as what Blume calls "an intractable oddity, a sarcastic old fogey." The authorities of the St. Thomas Church in Leipzig, where he was cantor, were all too visibly relieved when he died and they could hire a younger man more in tune with the times. Of his two most famous contemporaries, one (Telemann) expressed the verdict that Bach's sons, particularly Carl Philipp Emmanuel, were his greatest gift to the world, while the other (Handel) took not the slightest notice of him. See Blume, 15-16, 23, 25-26.

21. The author was J. N. Forkel, director of music at Göttingen University. Quoted in Blume, 38 .

22. Blume, 52-53, 56 .

23. As Blume points out, we have got beyond the ahistorical liberal idea of Bach as a creature of lonely genius fighting against the restrictions that church, dogma, family, and craft imposed on him-what he calls "Bach the restless titan." We now recognize the tradition of mysticism he inherited; we can also recognize the uncomfortable and paradoxical coexistence in him of a certain resignation of the will (identified by Nietzsche) with a certain violence of temperament (identified by Dilthey). See Blume, 69, 72-73. 


\title{
Chapter 14 \\ Fiction: The Power of Lies
}

\author{
Mario Vargas Llosa
}

Ever since I wrote my first short story, people have asked if what I wrote "was true." Though my replies sometimes satisfy their curiosity, I am left each time, no matter how sincere my answer, with a nagging sense of having said something that is not quite on target.

Whether novels are accurate or false is as important to certain people as whether they are good or bad, and many readers, consciously or unconsciously, link the two together. The Spanish Inquisitors, for example, prohibited novels from being published or imported in the Hispano-American colonies, claiming that those nonsensical, absurd books - untruthful, that is - could be harmful to the spiritual health of the Indians. Thus, for three hundred years, Hispano-Americans read only contraband works of fiction, and the first novel published as such in Spanish America did not appear until after Independence (1816, in Mexico). The Holy Office, in banning not only specific works but a literary genre in general, established what in its eyes was a law without exception: novels always lie, they all present a false view of life. Some years ago, I wrote a piece ridiculing those arbitrary fanatics. I now believe that the Spanish Inquisitors were the first to understandbefore critics and even novelists - the nature of fiction and its subversive tendencies.

In fact, novels do lie-they cannot help doing so-but that is only a part of the story. The other is that, through the lying, they express a curious truth, which can be expressed only in a veiled and concealed fashion, masquerading as what it is not. This statement has the ring of gibberish. But actually it is quite simple. Men are not content with their lot, and nearly all-rich or poor, brilliant or mediocre, famous or obscure-would like to have a life different from the one they lead. To (cunningly) appease this appetite, fiction was born. It is written and read to provide human beings with the lives they are unresigned to not having. The germ of every novel contains an element of nonresignation and desire. 
Does this mean that a novel is synonymous with unreality? That Conrad's introspective pirates, Proust's languid aristocrats, Kafka's anonymous, beleaguered little men, and the erudite metaphysical characters in Borges's stories arouse or move us because they have nothing to do with us and because it is impossible to identify their experiences with ours? Not at all. One must proceed cautiously, for this road-of truth and falsehood in the realm of fiction-is riddled with traps, and any enticing oasis is usually a mirage.

What does it mean to say that a novel always lies? Not what the officers and cadets believed at the Leoncio Prado Military Academy where-seemingly, at least-my first novel, The Time of the Hero, takes place, and where it was burned, accused of slandering the institution. Not what my first wife thought after having read another of my novels, Aunt Julia and the Scriptwriter, which she incorrectly construed as a portrait of herself, and which led her to publish a book purporting to restore the truth that had been altered by fiction. Both stories, of course, contain more inventions, deviations, and exaggerations than memories, and at no point in writing them did I seek to be literally faithful to certain persons and events prior to and extraneous to the novel. In both instances, as in everything I have written, I began with experiences still vivid in my memory and stimulating to my imagination and then fantasized something that is an extremely unfaithful reflection of that material.

Novels are not written to recount life but to transform it by adding something to it. In the novellas of the French writer Restif de la Bretonne, reality is as photographic as can be, a cataloguing of the eighteenth-century French customs. And yet, within that utterly painstaking enumeration of customs, where everything resembles real life, there is something else, different, minimal, and revolutionary - the fact that in this world men do not fall in love with women for the purity of their features, the grace of their body, their spiritual endowments, and so on, but exclusively for the beauty of their feet.

All novelists, less crudely, less explicitly, and also less consciously, remake reality - embellishing it or diminishing it - as did the prodigious Restif with delightful ingenuousness. These subtle, or crude, additions to life-wherein the novelist materializes his obsessions - constitute the originality of a work of fiction. Its profundity depends on how fully it expresses a general need and on the number of readers, through time and space, who can identify their own obscure, haunting demons with those contraband infiltrations of life. Could I, in those novels of mine, have attempted an exact correlation with actual memories? Of course. But even if I had accomplished that 
tedious feat of simply narrating actual events and describing people whose biographies fit their models like a glove, my novels would not thereby have been any less truthful or untruthful than they are.

Anecdote is not what essentially determines the truth or falsehood of a work of fiction, but rather the idea that it be not lived but written, that it be made up of words and not live experiences. Events translated into words undergo a profound modification. The actuality - the glory battle I participated in, the Gothic profile of the girl I loved-that is one thing, whereas the signs that describe it are countless. By selecting some and discarding others, the novelist favors one and kills off infinite other possibilities or versions of what he is describing. The novelist therefore changes nature; what describes becomes what is described.

I am referring here only to the case of the realistic writer, that sect, school, or tradition to which I belong, whose novels relate events that readers can recognize as plausible from their own experience of reality. It might, in fact, appear that the connection between reality and fiction is not even an issue for the novelist of a fantastic vein, who describes irreconcilable and clearly nonexistent worlds. Actually, it is an issue, but in another way. The "unreality" of fantastic literature becomes, for the readers, a symbol or allegory, in other words, a representation of realities, of experiences they can identify as being possible in life. What is important is this-the "realistic" or "fantastic" nature of an anecdote is not what marks the boundary line between truth and falsehood in fiction.

Along with this first modification-the imprint of words or events-there is another, no less fundamental: that of time. Real life flows without pause, lacks order, is chaotic, each story merging with all stories and hence never having a beginning or ending. Life in a work of fiction is a simulation in which that dizzying disorder achieves order, organization, cause and effect, beginning and end. The scope of a novel is not determined merely by the language in which it is written, but also by its temporal scheme, the manner in which existence transpires within it-its pauses and accelerations and the chronological perspective employed by the narrator to describe that narrated time.

Though there is a distance between words and events, there is always an abyss between real time and fictional time. Novelistic time is a device created to attain certain psychological effects. In it, the past can be subsequent to the present-effect preceding cause-as in the Alejo Carpentier story, Journey to the Seed, which begins with the death of an old man and continues until his conception within the maternal womb. Or it can merely be a 
remote past that never actually dissolves into the recent past, the point from which the narrator is narrating, as in most classical novels. Or it can be an eternal present without either past or future, as in Samuel Beckett's fictional works. Or a labyrinth in which past, present, and future coexist, annihilating each other, as in Faulkner's The Sound and the Fury.

Novels have a beginning and an end; and, even in the loosest and most disjointed ones, life takes on a discerning meaning, for we are presented with a perspective never provided by the real life in which we are immersed. This order is an invention, an addition of the novelist, that dissembler who appears to re-create life when, in fact, he is rectifying it. Fiction betrays life, sometimes subtly, sometimes brutally, encapsulating it in a weft of words that reduce it in scale and place it within the readers' reach. Thus the readers can judge it, understand it, and, above all, live it with an impunity not granted them in real life.

What difference is there, between a work of fiction and a journalistic report or a history book? Are they not, too, composed of words? And do they not, within the artificial time of the account, encapsulate that shoreless torrent, real time? It is a question of opposing systems in the approach to what is real: the novel rebels against life and transgresses it, other genres are unceasingly its slave. The notion of truthfulness or deception functions differently in both instances. In journalism or history, it hinges on the correlation between what is written and the corresponding reality: the closer it is the truer, and the farther away the falser. To say that Michelet's History of the French Revolution, or Prescott's Conquest of Peru, is "novelistic" is a criticism, an insinuation that they lack seriousness. Documenting the historical error of War and Peace with respect to the Napoleonic Wars would be a waste of time- the truth of the novel does not depend on facts.

On what, then, does it depend? On its own persuasive powers, on the sheer communicative strength of its fantasy, on the skill of its magic. Every good novel tells the truth and every bad novel lies. For a novel "to tell the truth" means to be unable to accomplish that trickery. The novel, thus, is an amoral genre; or rather, its ethic is sui generis, one in which truth and falsehood are exclusively esthetic concepts.

My foregoing remarks might suggest that fiction is a gratuitous fabrication, a juggling devoid of transcendence. On the contrary, wild as it may be, fiction's roots are submerged in human experience, from which it derives sustenance and which it in turn nourishes. A recurrent theme in the history of fiction is the risk incurred in taking what novels say literally, in believing 
that life is the way novelists describe it to be. Books on chivalry addle Don Quixote's brain and set him on the road to spearing windmills, and Emma Bovary's tragedy would not have occurred if Flaubert's character had not attempted to be like the heroines of the romantic novels she read.

By believing that reality is like fiction, Alonso Quijano and Emma Bovary undergo terrible upheavals. Do we condemn them for that? No, their stories move and awe us; that impossible determination to live fiction seems to personify for us an idealistic attitude that honors the species. To want to be different from the way one is, is the human aspiration par excellence. It has engendered the best and worst in recorded history. Including works of fiction.

When we read novels, we are not only who we are, but, in addition, we are the bewitched beings into whose midst the novelist transfers us. The transfer is a metamorphosis - the asphyxiating constriction of our lives opens up and we sally forth to be others, to have vicarious experiences that fiction converts into our own. A wondrous dream, a fantasy incarnate, fiction completes us, mutilated beings burdened with the awful dichotomy of having only one life and the ability to desire a thousand. This gap between real life and the desires and fantasies demanding that it be richer and more varied is the realm of fiction.

At the heart of all fictional work there burns a protest. Their authors created these lives because they were unable to live them, and their readers (and believers) encounter in these phantom creatures the faces and adventures needed to enhance their own lives. That is the truth expressed by the lies in fiction - the lies that we ourselves are, the lies that console us and make up for our longings and frustrations. How trustworthy then is the testimony of a novel on the very society that produced it? Were those people really that way? They were, in the sense that that was how they wanted to be, how they envisioned themselves loving, suffering, and rejoicing. Those lies document not their lives, but rather their driving demons - the dreams that intoxicated them and made the lives they led more tolerable. An era is populated not merely by flesh and blood creatures, but also by the phantom creatures into which they are transformed in order to break the barriers that confine them.

The lies in novels are not gratuitous-they fill in the insufficiencies of life. Thus, when life seems full and absolute, and people, out of an all-consuming faith, are resigned to their destinies, novels perform no service at all. Religious cultures produce poetry and theater, not novels. Fiction is an art of societies in which faith is undergoing some sort of crisis, in which it is necessary to believe in something, in which the unitarian, trusting, and 
absolute vision has been supplanted by a shattered one and an uncertainty about the world we inhabit and the afterworld.

Every novel, aside from being amoral, harbors at its core a certain skepticism. When religious culture enters into crisis, life seems divested of any binding schemes, dogma, and precepts and turns into chaos. That is the optimum moment for fiction. Its artificial orders offer refuge, security, and the free release of those appetites and fears that real life incites and cannot gratify or exorcise. Fiction is a temporary substitute for life. The return to reality is almost a brutal impoverishment, corroboration that we are less than we dreamed. Which means that fiction, by spurring the imagination, both temporarily assuages human dissatisfaction and simultaneously incites it.

The Spanish Inquisition understood the danger. Leading lives through fiction that one does not live in reality is a source of anxiety, a maladjustment to existence that can turn into rebelliousness, an unsubmissive attitude toward the establishment. One can well understand why regimes that seek to exercise total control over life mistrust works of fiction and subject them to censorship. Emerging from one's own self, being another, even in illusion, is a way of being less a slave and of experiencing the risks of freedom.

"Things are not as we see them but as we remember them," wrote Valle Inclan. He was undoubtedly referring to the way things are in literature, that spurious world that acquires a precarious sense of reality through the persuasive powers of the good writer and a certain readiness to accept on the part of the good reader.

For almost every writer, memory is the starting point of the imagination; it is the springboard that precipitates it on its indeterminate journey toward fiction. In creative literature, that which emanates from the memory and that which is invented are so inextricably interwoven that it is often quite impossible even for the author to distinguish one from the other; and although he may claim otherwise, he knows that any attempt to recuperate lost time through a work of literature can never be more than mere pretense, a work of fiction in which memories merge into fantasies and vice versa.

That is why literature is the domain par excellence of ambiguity. It is always subjective; it deals in half truths, relative truths, literary truths that frequently constitute flagrant historical inaccuracies or even lies. Although the almost cinematographic description of the battle of Waterloo that features in Les Misérables may exalt us, we are aware that this was a contest fought and won by Victor Hugo, and not the one lost by Napoleon. Or-to 
cite a Valencian medieval classic, Joanot Martorell-the conquest of England by the Moors described in Tirant lo Blanc is totally convincing, and no one would think of questioning its credibility with the petty argument that historically no Moorish army ever crossed the English Channel.

The reconstruction of the past through literature is almost always misleading in terms of historical objectivity. Literary truth is one thing, historical truth another. But, although it may be full of fabrication —or for that very reason-literature presents us with a side of history that cannot be found in history books. For literature does not lie gratuitously. All its deceits, devices, and hyperbole only serve to express those deep-seated and disturbing truths that come to light only in this oblique way.

When Johannot Martorell relates in Tirant lo Blanc that the Princess of France had such a white skin that one could see the wine going down her throat, he is telling us something technically impossible; and yet, captivated by the author's magic, we accept it as an incontrovertible truth because, in the simulated world of the novel (unlike what happens in real life), excess is never the exception, always the rule. Nothing appears excessive if everything is.

In Tirant, for instance, there are apocalyptic battles fought with a punctilious sense of ritual and exploits of a hero who, single-handed, routs the mob and literally ravages half of Christendom and the whole of Islam. There are comic rituals too, as demonstrated by that pious and lustful character who kisses women three times on the mouth in homage to the Holy Trinity. Everywhere we find excess - as with war, love too has generally cataclysmic consequences. Tirant, when he sees Carmesina's swelling breasts for the first time in the half-light of the funeral chamber, becomes nothing less than cataleptic, collapsing on a bed, where he remains without sleeping or eating or uttering a single word for several days. When he finally recovers, it is as if he were learning to speak again. The first words he stammers out are "Yo amo": "I am in love."

These fictitious events tell us not what the Valencians were really like at the end of the fifteenth century, but how they would have liked to have been and what they would have liked to have done; they depict not the characters of flesh and blood who actually lived in those terrible times, but merely ghosts that haunted them. It is their insatiable appetites, their fears and cravings, their grudges, that are brought to life. In a successful work of fiction it is the individual's experience of an age that comes to life; and that is why novels, although, when compared with history, they may be full of fabrication, nonetheless communicate to us certain transitory, evanescent truths 
that always defy purely scientific descriptions of reality. Only literature has the powers and techniques at its disposal to distil the delicate elixir of life: the truth that lies hidden at the heart of the human imagination.

Now there is nothing deceptive about the deceits of literature; at least, there should not be. Only simpletons who believe that literature must be objectively faithful to life and as dependent on reality as history is might think so. There is no deception, because when we open a work of fiction, we adjust our minds to participate in a performance where we know very well that the extent to which we are moved or bored will depend exclusively on the narrator's talent to captivate us and draw us into the world of his imagination-making us accept and experience his lies as if they were the truthand not on his ability to reproduce faithfully what actually happened.

These well-defined boundaries between literature and history-between literary truth and historical truth-are a prerogative of open societies. There they exist side by side, independently and in their own right, although complementing each other in a Utopian attempt to encompass the whole of life. And perhaps the most effective proof of an open society, in the sense Karl Popper used the term, is when the following occurs: when literature and history coexist autonomously without either encroaching on the territory or usurping the role of the other.

In closed societies the exact opposite occurs. And perhaps the best way of defining a closed society would be to say that in such a society, history and fiction have ceased to be two separate entities; they have become muddled up, each taking the other's place and swapping identities as at a masked ball.

In a closed society the authorities not only assume the right to control people's actions, what they do and what they say, but also aim to control their imaginations, their dreams and aspirations - and, of course, their memories. In a closed society, sooner or later the past becomes subject to a sort of manipulation specially designed to justify the present. The official version of history, the only one tolerated, is the setting for the extraordinary voltefaces made famous by the Soviet Encyclopedia. Protagonists appear and disappear without trace according to whether they have been redeemed or purged by the authorities; and the exploits of past heroes and villains alter, with every new edition, in sign, valency, and substance in accordance with the requirements of the dictatorial elite of the moment. This is a practice that modern totalitarianism has perfected but not invented; it dates back as far as the dawn of civilization, which, let us not forget, until relatively recently was always despotic and dictatorial. 
To organize the collective memory, to turn history into an instrument of the government whose role is to legitimize whoever is in power and to find alibis for their crimes, is a temptation inherent in all authority. Totalitarian states can make it a reality. In the past, countless civilizations put it into practice.

Take my ancient compatriots, the Inkas, for example. They effected it in a brutal and theatrical manner. When the emperador died, not only did his wife and concubines die with him, but also the court intellectuals who were known as amautas, or wise men. Their talents were applied essentially to performing the following little conjuring trick: creating history out of fiction. The new Inka would come to power with a brand new court of amautas responsible for renewing the official records, revising the past, by bringing it up-to-date so to speak, so that all the accomplishments, conquests, feats of engineering or architecture, and the like that were previously attributed to his predecessor would be from now on transferred to the new emperor's personal record of achievements. Gradually his predecessors would be forgotten-lost in oblivion.

The Inkas knew how to put the past to good use, turning it into literature, so that it could contribute toward the stabilization of the present-the ultimate ideal of any dictatorship. They prohibited personal accounts of what happened because those must always be at odds with an official account, which is of necessity coherent and unappealable. The result is that the Inka Empire is a society without a history, at least without any anecdotal history; for no one has been able to reconstruct with any degree of reliability a past that has been so systematically dressed up and undressed like a professional striptease artist.

In a closed society history becomes steeped in fiction, and so it actually becomes a work of fiction, because it is constantly being written and rewritten to serve religious orthodoxy or contemporary political theory or, even more crudely, to accord with the whims of the ruling power.

At the same time, a strict system of censorship is usually introduced, so that imaginative literature is kept within narrow limits, so that its subjective truths do not contradict or cast aspersions on the official version of history, but rather popularize and illustrate it. The difference between historical truth and literary truth disappears; and the two become fused into a sort of hybrid that imbues history with a sense of unreality and empties fiction of any mystery, originality, or spirit of nonconformity it may have toward the establishment.

To condemn history to tell lies and literature to propagate facts specially concocted by the authorities is no obstacle to the scientific or technological 
development of a country or the establishment of a certain social justice. It seems to have been proved that the Inka period-an extraordinary achievement for its time and for ours-put an end to hunger: everyone in the kingdom had enough to eat. And modern totalitarian societies have given a great impetus to education, medicine, sport, and employment, making them accessible to the majority of the people, something that open societies, despite their widespread prosperity, have not yet succeeded in doing, for the price of the freedom they enjoy is paid sometimes by enormous inequalities of wealth and-even worse-inequalities of opportunity among their members.

But when a state, in its zeal to control and decide everything, deprives human beings of the right to create freely and believe whatever lies they choose to believe, when it appropriates that right and exercises it like a monopoly through its historians or censors-as the Inkas did through their amautas - one of the great nerve centers of life is destroyed. And men and women suffer a sort of mutilation that impoverishes their existence even when their basic needs are taken care of.

Because the real world, the material world, has never been adequate, and never will be, to fulfill human desires. And without that essential dissatisfaction with life that is both exacerbated and at the same time assuaged by the lies of literature, there can never be any genuine progress.

The gift of the imagination with which we are all endowed is a diabolical one. It constantly opens up the abyss between what we are and what we would like to be, between what we have and what we covet.

But it has also produced an ingenious and gentle palliative to relieve the pain of the inevitable breach between our boundless desires and our practical limitations: fiction. Thanks to fiction we can grow and diversify without losing our basic identities. We can immerse ourselves in it, proliferate, living out many more lives than the ones we have, and many more than we would be able to were we to remain confined to reality without ever venturing out of the prison of history.

Men cannot live by truth alone; they also need lies - those they invent of their accord, not those foisted on them by others; those that emerge undisguised, not those that insinuate themselves through the trapping of history. Fiction enriches life, complements it, and offers fleeting compensation for man's tragic condition: that of always wanting and dreaming of more than he can realistically attain.

When literature is allowed to supply this alternative life, unimpeded, without any constraints except the limitations of the creator, then it extends 
the range of human experience by adding to it that dimension which nourishes our inner life - that intangible, elusive, yet invaluable one we experience only vicariously.

It is a right we must defend without shame. Because to play a game of lies, as the authors of works of fiction do with their readers-lies writers invent according to their own personal demons-is a way of asserting individual sovereignty and defending it when it is threatened. It is a way of preserving one's own sphere of freedom, a bastion beyond the control of the authorities, protected from the interference of others, inside which we are truly the masters of our own destinies.

And from that freedom other freedoms are born. Those private havens, the subjective truths of literature, give historical truth, their counterpart, a viable existence and a function of its own: that of recovering an important part—but only a part—of our past ... those moments of glory and wretchedness we share with others in our capacity as ordinary human beings. And there is no substitute for historical truth-it is indispensable if we are to know what we were and what we may become in terms of human society. But what we are as individuals, what we wanted to be and could not really be and therefore had to be in our dreams and imaginations - that secret side of our history-only literature can relate. That is why Balzac remarked that fiction was "the private history of nations."

By its very existence, it is a terrible indictment of life under any regime or ideology: a flagrant testimony of the inadequacies, the inability of such systems to fulfil us ... and therefore a permanent antidote to all authority that attempts to keep men content and compliant. The lies of literature, if they are allowed to flourish freely, are proof to us that this never was the case. And they are a permanent source of intrigue that ensures that it never will be in the future. 


\section{CONTRIBUTORS}

K. ANTHONY APPIAH is professor of Afro-American studies and philosophy at Harvard University. His most recent books are In My Father's House: Africa in the Philosophy of Culture (1992), Identities (1995), and (with Amy Guttmann) Color Conscious: The Political Morality of Race (1996). He is the editor (with Henry Louis Gates, Jr.) of The Dictionary of Global Culture (1997).

WALTER BERNS is professor emeritus of government at Georgetown University. His books include For Capital Punishment: Crime and the Morality of the Death Penalty (1979), In Defense of Liberal Democracy (1984), and Taking the Constitution Seriously (1987). He is resident scholar at the American Enterprise Institute.

BERNARD BOXILL is professor of philosophy at the University of North Carolina, Chapel Hill. He is the author of Blacks and Social Justice (1992).

JAMES CEASER is professor of government at the University of Virginia. His books include Reforming the Reforms (1982), Liberal Democracy and Political Science (1990), (with Andrew Busch) Upside Down and Inside Out: The 1992 Elections and American Politics (1992), and Reconstructing America: The Symbol of America in Modern Thought (1997).

LINDA CHAVEZ is president of the Center for Equal Opportunity. She is the author of Out of the Barrio: Toward a New Politics of Hispanic Assimilation (1991). She has served as White House director of public liaison, executive director of the U.S. Commission on Civil Rights, and president of U.S. English.

J. M. COETZEE'S most recent novels are Foe (1986), Age of Iron (1990), and Master of Petersburg (1994). His other works include White Writing: On the Culture of Letters in South Africa (1988), Doubling the Point: Essays and Interviews (1992), and Giving Offense: Essays on Censorship (1996). He is professor of general literature at the University of Cape Town. 
STANLEY FISH is Arts and Sciences Professor of English and professor of law at Duke University. His books include Doing What Comes Naturally: Change, Rhetoric, and the Practice of Theory in Literary and Legal Studies (1989), There's No Such Thing as Free Speech and It's a Good Thing Too (1994), and Professional Correctness: Literary Studies and Political Change (1995). He serves as executive director of Duke University Press.

NATHAN GLAZER is professor of education and sociology emeritus at Harvard University. His most recent books are Ethnic Dilemmas (1983), The Limits of Social Policy (1988), and We Are All Multiculturalists Now (1997). He serves as coeditor of Public Interest.

WILSON CAREY MCWILLIAMS is professor of political science at Rutgers University, New Brunswick. His books include The Idea of Fraternity in America (1973) and The Politics of Disappointment: American Elections, 1976-1994 (1995).

ARTHUR M. MELZER is professor of political science at Michigan State University. He is the author of The Natural Goodness of Man: On the System of Rousseau's Thought (1990). $\mathrm{He}$ is a director of the Symposium on Science, Reason, and Modern Democracy and an editor of its first two volumes of essays, Technology in the Western Political Tradition (1993) and History and the Idea of Progress (1995).

ANNE NORTON is professor of political science at the University of Pennsylvania. She is the author of Alternative Americas: A Reading of Antebellum Political Culture (1986), Reflections on Political Identity (1988), and Republic of Signs: Liberal Theory and American Popular Culture (1993).

LORRAINE PANGLE has taught at Groton School and the Community Hebrew Academy of Toronto. She is the author (with Thomas L. Pangle) of The Learning of Liberty: The Educational Ideas of the American Founders (1993).

MARC F. PLATTNER is coeditor of the Journal of Democracy, codirector of the International Forum for Democratic Studies, and counselor at the National Endowment for Democracy. He is the author of Rousseau's State of Nature (1979) and editor (with Larry Diamond) of The Global Resurgence of Democracy (1993), Nationalism, Ethnic Conflict, and Democracy (1994), and Civil-Military Relations and Democracy (1996).

MARIO VARGAS LLOSA'S most recent novels are The Storyteller (1989), In Praise of the Stepmother (1990), and Death in the Andes (1996). His other works include A Writer's Reality (1991) and A Fish in the Water: A Memoir (1994). 
JERRY WEINBERGER is professor of political science at Michigan State University. His books include Science, Faith, and Politics: Francis Bacon and the Utopian Roots of the Modern Age (1985) and The History of the Reign of King Henry the Seventh: A New Edition and Interpretation (1996). He is a director of the Symposium on Science, Reason, and Modern Democracy and an editor of its first two volumes of essays, Technology in the Western Political Tradition (1993) and History and the Idea of Progress (1995).

C. VANN WOODWARD is Sterling Professor of History emeritus at Yale University. His most recent books are Mary Chestnut's Civil War (1981), Thinking Back: The Perils of Writing History (1986), The Future of the Past (1989), and The Old World's New World (1991).

M. RICHARD ZINMAN is professor of political theory in James Madison College at Michigan State University. He is executive director of the Symposium on Science, Reason, and Modern Democracy and an editor of its first two volumes of essays, Technology in the Western Political Tradition (1993) and History and the Idea of Progress (1995). 
This page intentionally left blank 


\section{INDEX}

Abrams v. United States, 81

Achebe, Chinua, 37, 41, 42

Accommodation, 30, 107-8, 122, 139-40

Acculturation. See Assimilation

Addams, Jane, 22

Adorno, Theodore, 144

Aeneid, the, 201-2

Africa

and colonial rule, $38,57-58$

creative arts in, 57

cultural and racial identity in, 38-46,

$49,55-56,58-59$

and democracy, 159-60

ethnicity, 56, 58-59

and multiculturalism, 38, 46, 49, 57, 59

religion in, 43-44, 56-57

African American Baseline Essays, 178-79

African Americans

assimilation and exclusion of, $5,16,18$,

$19,20,22,25-26,27,28,29-32,34$,

62-64

and cultural identity, 55-56

and discrimination, 28, 29, 31-32,

$63-66,103-4,152$

and education, $63,66-68,169,178-82$

integration of, 34, 63, 153

African Development Bank, 42

Afrocentrism, 6, 32, 41, 49-50, 51, 66-67, $69,169,178-79,180$

Alexander, Larry, 87n25

Algeria, 58
Amalgamation, 20-21, 33

American Civil Liberties Union, 66

American Dilemma, An (Myrdal), 31

American identity, 16-18

Americanization Day, 21, 28

Americanization movement, 5, 19-25, 29, 62. See also Assimilation

Americans by Choice (Gavit), 22

Angola, 58

Appleby, Joyce, 145

Arendt, Hannah, 132

Areopagitica (Milton), 70

Arieli, Yehoshua, 18

Arnold, Matthew, 92

Asante, Molefi Kete, 178

Asian Americans, 19, 22, 27, 28, 29, 34,

$73,115,151-52,166-67,169$

Assimilation

of African Americans, 5, 18, 20, 22,

25-26, 28, 29-32, 34, 62-64

of Asian Americans, 27, 29-34

in Canada, 106-7

criticism of, 25-27, 171

definition of, 16, 17

disreputation of, $5,15,25,33$

and education, 23-24

as it exists today, $5,15,16,33,171-72$

of Hispanic Americans, 27, 29, 34

of immigrants, 23-24, 25-28, 29, 30,

$32-33,62,94,107$

of Jews, 31 
Assimilation (continued)

liberals on, 30, 32

responsibility for, 171

prior to the twentieth century, 16 ,

18-19, 62-63, 94

during the World Wars, 27-29

Azikiwe, Nnamdi, 43

Bach, Johann Sebastian, 11, 205-12

Balzac, Honoré de, 226

Beckett, Samuel, 219

Belgium, 61

Berlant, 87n30

Biafra, 43

Biologism, 9, 150, 155

"Black English," 63, 64

Black No More (Schuyler), 54n18

Black Reconstruction (Du Bois), 45, 54n18

Bloom, Allan, 92

Boaz, Franz, 150

Borglum, Gutzon, 22

Bosnia-Herzegovina, 59

Bouchard, Lucien, 107

Bourassa, Robert, 106

Bourne, Randolph, 26, 123

Brandeis, Louis, 21

Bretonne, Restif de la, 217

Bridgeman, Brent, 179

British North American Act of 1867, 106

Brown v. Board of Education, 63

Bryce, James, 62

Burke, Edmund, 130

Burma, 158

Canada, 62, 92-93, 106-7, 140, 173, 175

Carlin, David, 126

Carlyle, Thomas, 91-92

Carnegie Corporation Americanization

Studies series, 22, 23, 29

Carpentier, Alejo, 218

Catholicism, 121-22
Censorship, 221, 224

Charlottetown Accord, 107

Chesterton, G. K., 126

Chicago Cultural Studies Group, 85n 15

Childhood and Society (Erikson), 17

China, 158-59

Chinese Americans, 166-67

Closed societies, 223, 224

Cohen, Avern, 66

Coleridge, Samuel, 92

Communist party, 97, 98

Conference on Security and Cöoperation in Europe, 61

Constitution, U.S.

and discrimination, 153

and minority rights, $104-5,112,113$

and multiculturalism, 6-7, 8, 91, 93-95, 120-21, 122-24, 127, 133, 153

Coolidge, Calvin, 96

Crèvecoeur, J. Hector St. John de, 16, 62-63

Croatia, 59

Crummell, Alexander, 41

Cultural conflicts, 43-44, 58-62

Cultural pluralism, 15, 26, 27, 28, 91, 94-95, 101, 112, 160, 173

Cultural separatism, 63, 65-66, 67

Culture

and the arts, 57, 108, 141, 142

definition of, 46-47, 51-52, 55, 91-92, $118,140,147-48,149-51$

and diversity, 51-52, 72, 125, 151, 152

and education, 48-51, 183-84

and equality, 8, 125-26, 188

maintaining a, 171

and the media, $47-48$

and religion, 56-57, 94-95, 105, 150, 220-21

Culture and Democracy in the United

States (Kallen), 27

Czechoslovakia, 59 
Dannhauser, Werner J., 109

Declaration of Independence, 17, 120, 124

Democracy

definition of, 130

liberal, 7, 8, 105, 151-52, 154, 158, $161-62,185$

and majority rule, $7,112-13,115-16$, $118-19,124$

and religion, 121, 122

resurgence of, 157-62

Democratic institutions, 123-24

Democratic movements, 59, 157-62

Derrida, Jacques, 144

Dewey, John, 26

Disuniting of America, The (Schlesinger), 64

Dogmatism, 187, 188

Dorle, Jeanne, 180

Douglas, Stephen, 98, 102

Douglas, William O., 189

Douglass, Frederick, 65, 178

Du Bois, W. E. B., 41, 45, 54n18, 63, 65, 131,170

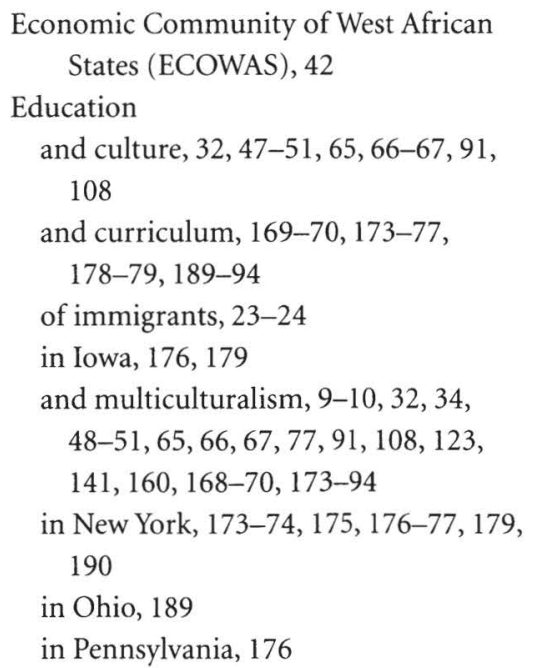

and segregation, 63, 66-68

and self esteem, 178-82

Supreme Court rulings on, 63, 100, 167

See also African Americans, and education

Eliot, T. S., 11, 199-204, 206

Emerson, Ralph Waldo, 18

Equality, 8, 23, 91, 102, 124, 125-26, 188

Equal opportunity, 113, 116, 125

Equal rights, 71-72, 96, 104-5, 106, 122, 145, 149, 151, 152, 157, 158-60, 162

Erikson, Erik H., 17

Ethnic conflicts, 42-45, 58-59, 60, 105, 157-58

Ethnicity, 17-18, 19, 33, 37, 42-44, 161, $171,173,175,182$

European Community, 61

Fabian, Johannes, 43

Fanon, Franz, 146

Faulkner, William, 219

Federalist, The, 93, 95-96, 97, 105, 120, 135

Fiction, 11-12, 216-26

Fitzpatrick, Father Joseph, 170

Flaubert, Gustave, 204

France, 61

Franklin, Benjamin, 178

Franklin, John Hope, 65, 170

Frazier, E. Franklin, 31

Frost, Robert, 130

Garveyism, 31

Gates, Henry Louis Jr., 66

Gavit, James A., 22

German Americans, 28

Ghana, 37, 43, 49

Gandhi, Mahatma, 181

Ghetto, The (Wirth), 31

Gleason, Philip, 16, 17-18

Gobineau, Arthur de, 143 
Goldberg, David Theo, $85 \mathrm{n} 15$

Great Britain, 61, 98-100, 104

Gutmann, Amy, 78-82, 86n23,

$87 \mathrm{nn} 25,28,29,30,92,103,104-5,140$

Habermas, Jürgen, 80-81, 82, 87n25

Hare, Thomas, 7, 119

Hate speech, 72, 79-81, 82-84, 87

Havel, Vaclav, 188

Hegel, Georg, 146, 150

Hegemon and the Other, 142-44, 147

Heidegger, Martin, 144

Herbert, Zbigniew, 212

Herzfeld, Michael, 125

Higham, John, 19

Hilliard, Asa, 178

Hirsch, E. D., 48

Hispanic Americans, 27, 29, 34, 49, 63, $147,151,165-66,169,170,171$

Historical truth and understanding, 41, $130,132,168,170,174,209,222$, $223,224,225-26$

Hitler, Adolf, 27, 28, 29

Holmes, Oliver Wendell, 81

Houghton, James, 76

Huntington, Samuel P., 105

"I am an American Day," 28

Idea of the University, The (Pelikan), 67

Immigrants

assimilation of, 17, 19-22, 23-24,

$25-28,29,30,32-33,62,94,107$

and education, 23-24, 167

restriction of, 26, 97

in the twentieth century, 165, 166

Inclan, Valle, 221

Integration, 31, 153, 155, 172

Intermarriage, 5, 21, 34

Inter-Racial Council, 21-22

Italian Americans, 28, 167
Japanese Americans, 28, 115, 166-67

Jefferson, Thomas, 94, 100, 101, 102, 108, $123,182,184$

Jeffries, Leonard, 178

Jews, 19, 31, 33, 50, 64, 104, 115

Journey to the Seed (Carpentier), 218

Jurisprudence, 168

Jury trials, 103-4, 105

Kahane, Rabbi Meir, 103

Kaixi, Wuer, 158-59

Kallen, Horace, 26, 27, 30, 94

Keats, John, 92

Kellor, Frances, 20-21

Khomeini, Ayatollah Ruholla, 73, 103

Kifer, Edward, 180

King, Martin Luther Jr., 63, 181, 182

Kohn, Hans, 18

Ku Klux Klan, 19, 26

Kunstler, William, 103

Kyi, Aung San Suu, 158

Kymlicka, Will, 86n21, 87n30

Laitin, David, 43

Lamm, Richard, 165

Language and bilingualism, 49, 63, 106, 173 and cultural diversity, 56 and multilingualism, 47

Lenin, 146

Lessing, Gotthold, 186

Letter on Toleration (Locke), 101

Letters from an American Farmer (Crèvecoeur), 16

Levesque, Rene, 106

Lewis, Arthur, 119n5

Lewis, Bernard, 99

Lewis, Read, 33

Liberalism, 2, 6, 9, 30, 32, 81-82, 83-84, 86n21, $87 \mathrm{n} 28,142-43,145,149,152,153$ 
Liberia, 58, 63

Liberty, 108-9, 145, 157, 193

Lincoln, Abraham, 96-97, 98, 102, 155

Lindsay, Vachel, 132, 138n7

Lipset, S. M., 18

Literature, 199-206, 210, 216-26

Locke, John, 92, 101, 102, 132, 136

Los Angeles riots, 37, 44, 53n2

McLaren, Peter, 85n15

Madison, James, 94, 95-96, 97, 100, 131, 135,136

Majorities, 112-19, 123, 135, 142-44

Malwal, Bona, 159

Mansfield, Harvey, 124

Marcuse, Herbert, 3

Martorell, Johannot, 222

Marx, Karl, 3, 4

Marxism, 1, 3-4, 31, 45, 67-68, 146, 158

Meech Lake Accord, 106

Melville, Herman, 133

Mendus, Susan, 86n23, 87n30

Merchant of Venice, The (Shakespeare), 91

Mill, John Stuart, 7, 71, 92, 113, 117, 118, 119

Milton, John, 70, 75

Minorities, 7, 112-19, 142-44

Moore, Joan, 170

Mormons, 97-98

Mulroney, Brian, 106

Multiculturalism

in Africa, 38, 46

and the arts, 108

boutique, 69-73, 74, 75

in Canada, 62, 92-93, 106-7, 173, 175

categorization of, 142-44, 146-47

definition of, 1-4, 5, 6, 46, 48, 69- 70, $75,76,77,78,92,123,139-42,147$, 148,160 and democracy, 123-26, 127, 133, 135, 160

democratic, 123-26

and demographics, 75-76

effects of, 7, 8, 51, 52, 131-35, 154-55

and equality, 71-72, 91

in Europe, 59-61, 99, 104

and exclusion, 80, 81-82, 87n28, 103

in Great Britain, 99-100, 104

limitations of, 8-9, 10, 146-48, 150

moderate, $10-11$

origin of, 144, 146

radical, 10, 161-62

and self-esteem, 178-82

strong, 69, 73-75

in the work place, 76-77

See also Constitution, U.S., and multiculturalism; Cultural pluralism; Education, and multiculturalism

Multiculturalism and the Politics of Recognition, 140

Multicultural separatist movements, 64 , 65-66

Music, 205-12

Muslims, 98, 99, 100

Mussolini, Benito, 185-86

Myrdal, Gunnar, 31, 62

National identity, 16, 17-18

Nationalism, 43, 62, 93, 161, 208

Native Americans, 18, 62, 73, 152, 169

Naturalization, 22, 25, 94

Ndue, Paul Ntungwe, 159

New Left, 3, 4

New York Social Studies Review and

Development Committee, 176-77, 190

Nietzsche, Friedrich, 3, 4, 136

Nigeria, 43-44, 56, 58

Northern Ireland, 104 
Northern Peoples' Congress, 43

Norton, Anne, 120

Nosair, El Sayyid A., 103

Nyong'o, Peter Anyang', 159

On Liberty (Mill), 71, 117

Organization of African Unity (OAU), $40,42,45$

Pachon, Harry, 170

Pan-Africanism, 45-56

Park, Robert E., 29-31

Particularism, 157

Patriotism, 177-78

Pelikan, Jaroslav, 67

Pinckney, Charles Cotesworth, 124

Plunkitt, George Washington, 122

Pluralism, 2, 5, 10, 38, 50, 52, 108, 109n7,

123. See also Cultural pluralism

Politics of difference, 72-73

Politics of Difference (Young), 142

Popper, Karl, 223

Pound, Ezra, 202

Pupin, M. I., 22

Race

in Africa, 38-46

alliances based on, 40

definition of, 22, 28, 39-40, 41

and minorities, 29

misconceptions of, 39-41

Racialism, 9, 150

Racism, 28, 39, 40, 44, 45, 72-73, 83-84, $86 \mathrm{n} 23,145,155,181-82$

Rationalism, 3, 144, 145

Rawls, John, 85n9, 86n23, 87n30

Relativism, 185-87, 188

Religion, 47, 71, 220-21

in Africa, 43-44, 56-57

and the Constitution, 97, 98, 101-3, 122 and culture, 56-57, 94-95, 150, 220-21

and ethnic conflict, 43-44, 105

in Great Britain, 98-100

Supreme Court rulings on, 100

and tolerance, 97-98, 121, 122

Religious fundamentalism, 69, 73, 74,

80-81

Representation, 7, 113-16, 119, 124, 157

Representative Government (Mill), 113

Robinson, Cedric, 54n18

Rockefeller, Steven C., 70, 71, 82, 87n30

Roosevelt, Franklin D., 28, 181

Roosevelt, Theodore, 28

Rorty, Richard, 87n29

Ross, David, 108

Rousseau, Jean-Jacques, 131, 146

Rubin, Rosalyn A., 180

Rushdie, Salman, 6, 7, 69, 73, 74, 99, 103

Russia, 60

Sandridge, Suzanne, 180

Scheibe, Johann Adolf, 207

Schiff, Jacob, 22

Schlesinger, Arthur Jr., 37, 64

Schooling of the Immigrant, The (Thompson), 23

Schuyler, George, $54 \mathrm{n} 18$

Sedgwick, Theodore, 94

Segregation, 34, 63, 66-68, 116, 119

Sennett, Richard, 145

Shakespeare, William, 91, 95

Shelley, Percy, 92

Shipman, Virginia, 179

Sixties radicalism, 2-3, 4

Slaughter, M. M., 74

Slavery, 57, 96, 102, 120-21, 124, 145

Smith, Adam, 92

Solzhenitsyn, Alexander, 188

Sound and the Fury, The (Faulkner), 219

South Africa, 56 
Southern African Development Coordination Conference (SADCC), 42

Soviet Union, 60, 161

Soyinka, Wole, 41

Spain, 61

Speech codes, 72, 82-84

Stella, Antonio, 22

Strauss, Leo, 108

Sudan, the, 159

Supreme Court, U.S., 63, 97-98, 100, 104, 167

Sutherland, George, 98

Swartz, Marc, 125

Taylor, Charles, 71-72, 76, 92, 140, 142, 146

Theroux, Paul, 74, 82

Thomas, Clarence, 144

Thompson, Frank V., 23-24

Tirant lo Blanc (Martorell), 222

Tocqueville, Alexis de, $8,62,91,92$, 99, $120,121-22,135,189$

Tolerance, 23, 29, 73-74, 97-98, 117, 120, $121,122,142,143,147,148,167$, $176,185,187$

Tradition, 204

Tribalism, 42-44, 45, 59

Trudeau, Pierre Elliott, 92, 106, 173

Uganda, 56

United Nations, 42, 61

Universalism, 9, 83, 136, 157, 160-61
Virgil, 200-202, 204

(Virginia) Bill for Religious Freedom, 101,102

Wald, Lillian, 22

Walker, David, 63

Warner, Michael, 87n30

Warren, Earl, 63

Washington, George, 110n24

Waters, Mary, 33

Webster, Noah, 174

West, Cornel, 144-45

Whitman, Walt, 18, 131, 136

Whitney Museum Biennial Exhibition of American Art, 108, 141, 142

Wilson, Woodrow, 21, 28

Wiredu, Kwasi, 41

Wirth, Louis, 31

Wolfe, Tom, 69

Woodsen, Carter, 170

Wordsworth, William, 92

World Bank, 42

Yeltsin, Boris, 60

Young, Iris Marion, 142, 145

Yugoslavia, 59-60, 61, 158

Zaire, 43-44, 56, 58 


\section{Multiculturalism:}

Is it the face of twenty-first-century America or merely a passing intellectual fad? With its celebration of ethnic diversity and strong advocacy of tolerance, this contemporary movement provides philosophical justification for many who seek to correct social inequities. But while its proponents see it as a means of promoting self-esteem among marginalized groups, its critics see it as a dangerous form of relativism that culminates, paradoxically, in a new form of intolerance.

"This is a marvelous volume on a thorny issue. It can be read by both beginners and experts. They will all come away with a better understanding and appreciation of multiculturalism."-Choice

"Highly recommended for initiated readers of every persuasion who wish to understand the multiculturalism debate better."-MultiCultural Review

"This collection of essays offers a superb vehicle for those of us who teach "moral' conflicts and wish to engage our undergraduates in a serious discussion of the many facets of multiculturalism."-American Review of Politics

Arthur M. Melzer is professor of political science at Michigan State University. He is the author, editor, or coeditor of eleven books, including The Supreme Court and the Idea of Constitutionalism.

Jerry Weinberger is university distinguished professor emeritus of political science at Michigan State University. He has written, edited, and coedited several books on political thought, including Benjamin Franklin Unmasked: On the Unity of His Moral, Religious, and Political Thought.

M. Richard Zinman is university distinguished professor emeritus of political theory in James Madison College at Michigan State University. With Melzer and Weinberger, he has coedited several books on democracy and modern politics.

\section{University Press of Kansas}

Lawrence KS 66045

www.kansaspress.ku.edu

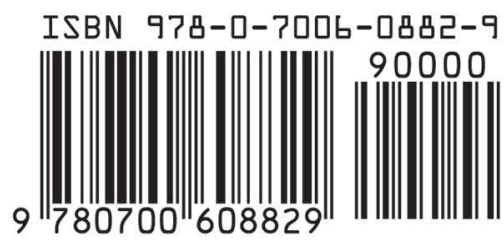

